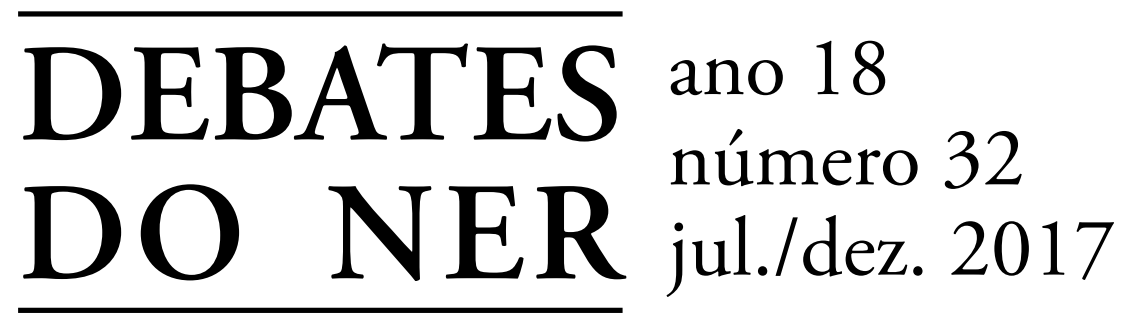

20 ANOS: 1997-2017

PUBLICAÇÃO DO NÚCLEO DE ESTUDOS DA RELIGIÃO DO PROGRAMA DE PÓS-GRADUAÇÃO EM ANTROPOLOGIA SOCIAL DA UNIVERSIDADE FEDERAL DO RIO GRANDE DO SUL 
UNIVERSIDADE FEDERAL DO RIO GRANDE DO SUL

Reitor: Rui Vicente Oppermann

\section{INSTITUTO DE FILOSOFIA E CIÊNCIAS HUMANAS}

Diretora: Claudia Wasserman

\section{PROGRAMA DE PÓS-GRADUAÇÁO EM ANTROPOLOGIA SOCIAL}

Coordenadora: Patrice Schuch

\section{EXPEDIENTE}

Núcleo de Estudos da Religião (NER)

Programa de Pós-Graduação em Antropologia Social (IFCH/UFRGS)

Av. Bento Gonçalves, 9500 - Porto Alegre - RS - 91509-900

Telefone: (51) 3308-6866 / E-mail: ner@ifch.ufrgs.br

Site: www.ufrgs.br/ner

\section{INDEXADORES}

Latindex; Index Copernicus; EBSCO; RCAAP; DOAJ.

\section{EDITORES}

Eduardo Dullo (UFRGS)

Rodrigo Toniol (UNICAMP)

\section{COMISSĀO EDITORIAL EXECUTIVA}

Ari Pedro Oro (UFRGS)

Bernardo Lewgoy (UFRGS)

Carlos Alberto Steil (UFRGS)

Emerson Giumbelli (UFRGS)

BOLSISTA RESPONSÁVEL

Giane Krüger

\section{GRÁFICA DA UFRGS}

Acompanhamento Editorial: Michele Bandeira

Editoração: Marta Zimmermann

Revisão de padrão: Ana Santos e Camila Meurer Jandrey

Imagem da capa: Gabriel Fragoso de Freitas

\section{CONSELHO EDITORIAL}

André Corten - Université du Québec (Canadá)

Cecília Loreto Mariz - Universidade Estadual do Rio de Janeiro (Brasil)

Marcelo Camurça - Universidade Federal de Juiz de Fora (Brasil)

Marjo de Theije - Vrije Universiteit Amsterdam (Holanda) Maria das Dores Machado - Universidade Federal do Rio de Janeiro (Brasil)

María Julia Carozzi - Universidad Católica de Buenos Aires (Argentina)

Otávio Velho - Universidade Federal do Rio de Janeiro (Brasil)

Patrícia Birman - Universidade Estadual do Rio de Janeiro (Brasil)

Renzo Pi Hugarte - Universidad de la República (Uruguai) (in memoriam)

Ricardo Mariano - Universidade de São Paulo (Brasil)

Rita Laura Segato - Universidade de Brasília (Brasil)

Roberto Cipriani - Università degli Studi Roma Tre (Itália)

Ronaldo Almeida - Universidade Estadual de Campinas (Brasil)

Ruy Blanes - Universidade de Lisboa (Portugal)

Stefania Capone - Université de Paris X Nanterre (França)

Vincenzo Pace - Università di Padova (Itália)

\section{MISSÃO}

A religião se apresenta como uma das questóes mais recorrentes e universais da sociedade, tendo se constituído num tema clássico de estudo e pesquisa nas Ciências Sociais e Humanas. Sua longa duraçáo histórica a torna um fato social diversificado e de grande atualidade, que exige aprofundamento e pesquisa constante. O Núcleo de Estudos da Religiăo (NER), integrado ao Programa de Pós-Graduação em Antropologia Social da Universidade Federal do Rio Grande do Sul, é hoje uma referência nacional na área dos estudos da religião, tendo em seu periódico, Debates do NER, um importante veículo de divulgação dos resultados das pesquisas realizadas por seus membros e de intercâmbio com outros núcleos no país e no exterior.

\section{POLÍTICA EDITORIAL}

Debates do NER é um periódico semestral publicado pelo Núcleo de Estudos da Religiấo (NER) do Programa de PósGraduação em Antropologia Social da Universidade Federal do Rio Grande do Sul (UFRGS). Seus números divulgam textos científicos inéditos decorrentes de pesquisas realizadas na área das Ciências Sociais, relacionadas à presença da religião como fato social e às suas interfaces com outras esferas da sociedade. Possui abrangência nacional e internacional, estendendo-se para os países do Mercosul por meio de uma extensa e qualificada rede de cientistas sociais da religiáo que têm publicado com regularidade no periódico.

\section{DADOS INTERNACIONAIS DE CATALOGAÇÃO NA PUBLICAÇÃO (CIP)}

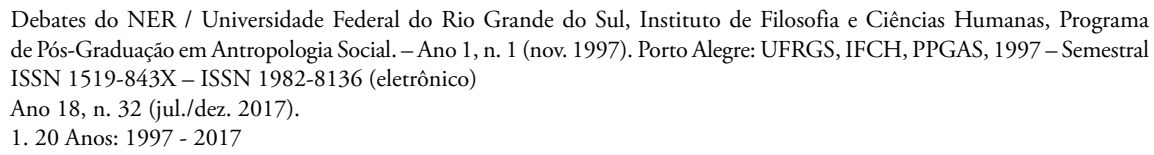




\section{SUMÁRIO}

\section{APRESENTAÇÁO}

Eduardo Dullo

\section{DEBATE}

ELEIÇŌES MUNICIPAIS 2016: RELIGIÃO E POLÍTICA

NAS CAPITAIS BRASILEIRAS

Erico Tavares de Carvalho Junior

Ari Pedro Oro

\section{COMENTÁRIOS}

Cecília Loreto Mariz $\quad 71$

Paul Freston $\quad 81$

Brenda Carranza $\quad 87$

Marcelo Tadvald 117

Erico Tavares de Carvalho Junior e Ari Pedro Oro 135

\section{ARTIGOS}

ANTROPOLOGIA E FILOSOFIA POLÍTICA:

UMA RELAÇÃO ESTRANHA? OU COMO ANALISAR

CONTROVÉRSIAS ENTRE CIDADÃOS SECULARES

E RELIGIOSOS EM UMA DEMOCRACIA LIBERAL

Cleonardo Mauricio Junior

Roberta B. C. Campos

Eduardo Henrique Gusmão

EXPERIENNCIA E CONHECIMENTO VIVIDO NO TERREIRO:

ASPECTOS DA UMBANDA DE PAI JOAQUIM

Lucas Gonçalves Brito 
O SIGNIFICADO DO DAIME COMO FONTE

DE CONHECIMENTO

Amurabi Oliveira

Felipe Boin

AS FACES DE DEUS: UM ESTUDO EXPLORATÓRIO

COM CRIANÇAS E ADOLESCENTES

Lorena Santos Ricardo

Antônio Carlos Ortega

Heloisa Moulin de Alencar

AS MUITAS FACES DE NOSSA SENHORA DOS REMÉDIOS

Lidice Meyer Pinto Ribeiro

\section{ENTREVISTA}

EN MARGE DU DOSSIER SUR L'EMPATHIE

EN ANTHROPOLOGIE

Jeanne Favret-Saada

Cyril Isnart

\section{RESENHAS}

SUÁREZ, HUGO JOSÉ. CREYENTES URBANOS:

SOCIOLOGÍA DE LA EXPERIENCIA RELIGIOSA

EN UNA COLONIA POPULAR DE LA CIUDAD DE MÉXICO.

MÉXICO: UNIVERSIDAD NACIONAL

AUTÓNOMA DE MÉXICO, 2015.

Karina Bárcenas Barajas

VERKAAIK, OSKAR (ORG.). RELIGIOUS ARCHITECTURE: ANTHROPOLOGICAL PERSPECTIVES. AMSTERDAM: AMSTERDAM UNIVERSITY PRESS, 2013. 


\section{SUMMARY}

PRESENTATION

Eduardo Dullo

\section{DEBATE}

MAYORAL ELECTIONS IN 2016: RELIGION AND POLITICS IN BRAZILIAN STATE CAPITALS

Erico Tavares de Carvalho Junior

Ari Pedro Oro

\section{COMMENTS}

Cecilia Loreto Mariz $\quad 71$

Paul Freston $\quad 81$

Brenda Carranza $\quad 87$

Marcelo Tadvald 117

Erico Tavares de Carvalho Junior e Ari Pedro Oro 135

\section{ARTICLES}

ANTHROPOLOGY AND POLITICAL PHILOSOPHY:

AN AWKWARD RELATIONSHIP? OR HOW TO ANALYZE

CONTROVERSIES BETWEEN SECULAR AND RELIGIOUS

CITIZENS IN A LIBERAL DEMOCRACY

Cleonardo Mauricio Junior

Roberta B. C. Campos

Eduardo Henrique Gusmáo

EXPERIENCE AND LIVED KNOWLEDGE IN THE TERREIRO:

ASPECTS OF PAI JOAQUIM'S UMBANDA

Lucas Gonçalves Brito 
THE MEANING OF DAIME AS A SOURCE OF KNOWLEDGE 203 Amurabi Oliveira Felipe Boin

THE FACES OF GOD: AN EXPLORATORY STUDY WITH CHILDREN AND TEENAGERS

Lorena Santos Ricardo Antônio Carlos Ortega Heloisa Moulin de Alencar

THE VARIOUS FACES OF OUR LADY OF GOOD REMEDY 259 Lidice Meyer Pinto Ribeiro

\section{INTERVIEW}

EN MARGE DU DOSSIER SUR L'EMPATHIE EN ANTHROPOLOGIE Jeanne Favret-Saada Cyril Isnart

\section{BOOK REVIEWS}

SUÁREZ, HUGO JOSÉ. CREYENTES URBANOS: SOCIOLOGÍA DE LA EXPERIENCIA RELIGIOSA EN UNA COLONIA POPULAR DE LA CIUDAD DE MÉXICO. MÉXICO: UNIVERSIDAD NACIONAL AUTÓNOMA DE MÉXICO, 2015.

Karina Bárcenas Barajas

VERKAAIK, OSKAR (ORG.). RELIGIOUS ARCHITECTURE: ANTHROPOLOGICAL PERSPECTIVES. AMSTERDAM: AMSTERDAM UNIVERSITY PRESS, 2013. 


\section{APRESENTAÇÃO}

Neste ano de 2017, a revista Debates do NER completa 20 anos de existência. A sua trajetória de sucesso pode ser observada on-line e gratuitamente, desde o seu primeiro número, na plataforma do SEER da Universidade Federal do Rio Grande do Sul. É parte da proposta da revista publicar artigos, resenhas e, sobretudo, estimular o debate acerca dos fenômenos religiosos. Nesse sentido, a Debates do NER publica sempre um artigo que abre o número, ampliando e adensando a discussão. Imbuído dessa disposição, Carlos Alberto Steil foi editor da revista até a sua maturidade e a conduziu à posição em que ela se encontra hoje: um periódico conhecido e reconhecido pela sua excelência e pela sua contribuição. Nestes dois números de 2017, Carlos Alberto Steil deslocou-se da posição de editor para a de membro da Comissão Editorial e, gentilmente, convidou-me para assumir a edição. Neste primeiro número que organizo, agradeço a honra do convite e a confiança no meu trabalho para, junto com Rodrigo Toniol, continuar um percurso de tamanho sucesso.

O número 32 da revista apresenta como artigo de debate o texto "Eleiçôes municipais 2016: religião e política nas capitais brasileiras”, de Erico Tavares de Carvalho Junior e Ari Pedro Oro. Essa é mais uma motivação para a celebraçáo destes 20 anos, visto que a Debates do NER foi inaugurada em 1997 com um artigo-debate de Ari Pedro Oro, com o título "Neopentecostais e Afro-brasileiros: quem vencerá essa guerra?”. O texto que publicamos agora oferece, portanto, um novo olhar para um dos temas centrais para os estudiosos da religião no Brasil, desdobrando no tempo os impactos da "guerra santa" que se discutia naquele primeiro número. De 1997 até 2017, tal embate se fez crescer tanto na experiência concreta dos sujeitos religiosos quanto na mídia tradicional e nas novas mídias, a ponto de envolver toda a sociedade brasileira, e não mais apenas aqueles diretamente submetidos 
ao conflito. Temos, hoje, debates locais, regionais e nacionais acerca das posiçóes adquiridas e das almejadas por diversos setores religiosos cristáos (católicos e evangélicos); discussões acerca das transformações na compreensão da laicidade e dos limites (ou a falta deles) entre religião e política; novas açôes e percepçôes acerca da intolerância e das dificuldades colocadas pelo crescente pluralismo religioso brasileiro.

A contribuição de Carvalho e Oro revisita outros textos e trabalhos realizados e publicados anteriormente acerca da presença de representantes políticos nas eleiçóes. Entretanto, parte significativa da originalidade da contribuição é o fato de que tal feito é realizado não mais tendo como foco as casas representativas federais, mas um olhar cuidadoso e amplo acerca das candidaturas municipais para vereadores nas capitais brasileiras. Supre-se, assim, uma lacuna imensa - tanto pela importância desse fenômeno quanto pela sua extensão -, que envolveu uma pesquisa com aproximadamente 17 mil candidaturas. Dada a importância da iniciativa e a generosidade de Carvalho e Oro em prover o pesquisador com tabelas e dados até então inexistentes, os autores nos permitem ampliar nossas análises para cenários em que a relação entre políticos e população é de outra ordem, senão de outra natureza.

Os debates e comentários permitirão ao(à) leitor(a) desenvolver suas próprias críticas e ideias para análise. Os textos de Cecilia Mariz (que também debateu o artigo de Oro em 1997), Paul Freston, Marcelo Tadvald e Brenda Carranza certamente estimularão no(a) leitor(a) uma série de questionamentos, dentre os quais elenco os seguintes: que correlaçôes existem entre as transformaçóes populacionais em cada capital no que concerne ao pertencimento religioso e as candidaturas e eleições de representantes? Que reflexôes vêm à luz ao evitar casos midiáticos próprios a uma espetacularização de certas candidaturas? Que relaçóes entre religião e política ficam na penumbra, ignoradas por pesquisadores, mesmo os mais experientes? A proporção de candidaturas de mulheres evangélicas pode nos dizer algo sobre a dinâmica de gênero e de liderança das igrejas? E o que nos dizem os dados sobre as candidaturas de membros de religióes de matriz africana? $\mathrm{O}$ 
leitor verá que, estimulada pelo artigo de Carvalho e Oro, Brenda Carranza produz um novo artigo no qual procede a uma retomada de uma série de reflexóes para compreender se há e qual seria um modus operandi evangélico na política brasileira, bem como os impactos no modo como agentes católicos se manifestam politicamente.

Em "Antropologia e Filosofia Política: uma relação estranha? Ou como analisar controvérsias entre cidadáos seculares e religiosos em uma democracia liberal", os três autores, Cleonardo Gil de Barros Mauricio Junior, Roberta Bivar Carneiro Campos e Eduardo Henrique Araújo de Gusmão, inspiram-se no artigo de Joel Robbins acerca da relação entre Antropologia e Teologia para debater a "relação estranha" entre a Antropologia e a Filosofia Política no que diz respeito às possibilidades de análise de eventos que fazem colidir identidades religiosas e seculares nas democracias liberais modernas. Posto o conhecimento acumulado pela Filosofia Política a esse respeito, os autores nos conduzem a outra compreensáo da especificidade da contribuiçáo antropológica. Assim, primeiro apresentando a abordagem de Jürgen Habermas, Charles Taylor e Talal Asad e, depois, contrastando o último com os dois primeiros, os autores nos levam a questionar a rentabilidade de posiçóes teóricas normativas na compreensão de embates políticos contemporâneos. Estaremos, em nossas pesquisas e análises, operando dentro da chave normativa que os autores percebem existir na Filosofia Política? E "até onde uma episteme normativa pode contribuir para um modo de construir conhecimento que trabalha diretamente com contextos empíricos específicos"?

Lucas Gonçalves Brito, em "Experiência e conhecimento vivido no terreiro: aspectos da umbanda de Pai Joaquim", nos apresenta parte de sua pesquisa realizada em Goiânia, na qual há uma compreensão e formulaçáo da umbanda como uma forma de conhecimento que dissolve a dualidade religiáo-ciência. Ao focar o conceito de experiência e as expressóes passíveis de serem apreendidas pelo pesquisador, como as narrativas, Brito nos conduz de maneira fascinante pelas trajetórias de três médiuns, elucidando a paciência do aprendizado dessa experiência como náo apenas uma episteme, mas como uma epistemologia. 
Amurabi Oliveira e Felipe Boin, por sua vez, nos trazem em "O significado do Daime como fonte de conhecimento" uma reflexão na mesma direção: apoiando-se nas recentes críticas ao exclusivismo epistemológico das ciências ocidentais, os autores exploram como a ayahuasca utilizada no Santo Daime permite a ampliação de outros saberes. "Mas que conhecimento seria esse? O que querem dizer com conhecimento e, ainda, como esse conhecimento é transmitido?" Tais questóes, elaboradas ao longo do artigo, nos fazem perceber a potência e a importância do descentramento dos processos de aprendizagem e de transmissão de conhecimentos a partir de uma planta professora.

Já o artigo de Lorena Santos Ricardo, Antônio Carlos Ortega e Heloisa Moulin de Alencar, intitulado "As faces de Deus: um estudo exploratório com crianças e adolescentes", nos faz questionar, a partir da Psicologia, como as crianças (de 6 e 10 anos) e os adolescentes (de 14 anos) formulam representaçóes de Deus. Como se constrói, progressivamente, esse conceito? Que diferenças e semelhanças podemos encontrar entre essas faixas etárias? Quais são as relaçóes com o contexto social e familiar?

Em "As muitas faces de Nossa Senhora dos Remédios", Lidice Meyer Pinto Ribeiro analisa a iconografia e a difusão da devoção, bem como suas transformaçóes em diferentes locais da Europa (como Portugal, Itália, França e Espanha) e no Brasil ao longo dos séculos (do século XII ao momento contemporâneo). $\mathrm{O}$ artigo constitui, portanto, uma importante contribuição para os estudos sobre as devoçóes e representaçôes de Maria e para os estudos sobre santidade de uma forma geral. Além disso, a centralidade da libertaçáo de cativos (e a redenção) é objeto de discussão da autora, e sua conclusão é instigante para pensarmos nas modificaçôes derivadas das transformaçóes contextuais e históricas das devoçôes, com a passagem para a possibilidade de remediar.

Além desses ótimos artigos e dos debates por eles proporcionados, este número conta com uma traduçáo da entrevista concedida por Jeanne Favret-Saada a Cyril Isnart em 2007 e publicada em 2008 no Journal des Anthropologues. A antropóloga responde a perguntas sobre seu método e sobre 
sua percepção do que é a Antropologia, desde os anos 1960, quando começa seu trabalho de campo na Algéria, com o incentivo de Ernest Gellner, até a publicaçáo de Désorceler (2009), que estava no prelo no momento da entrevista. Fechamos este número com duas resenhas. A primeira, de Karina Bárcenas Barajas, discute um livro de Hugo José Suárez - Creyentes urbanos: sociología de la experiencia religiosa en una colonia popular de la Ciudad de México. A segunda, de Adriano Santos Godoy, discute a coletânea Religious architecture: anthropological perspectives, organizada por Oskar Verkaaik.

Boa leitura!

Eduardo Dullo 

DEBATE 



\title{
ELEIÇÓES MUNICIPAIS 2016: RELIGIÃO E POLÍTICA NAS CAPITAIS BRASILEIRAS ${ }^{1}$
}

\author{
Erico Tavares de Carvalho Junior ${ }^{2}$ \\ Ari Pedro Oro ${ }^{3}$
}

Resumo: $\mathrm{O}$ presente trabalho visa a contribuir para uma perspectiva nacional da problemática acerca da imbricação entre religião e política durante o processo eleitoral de 2016 nas capitais brasileiras. O texto possui um caráter expositivo comparativo buscando privilegiar a apresentaçáo dos dados, acompanhados de uma breve análise. Desta forma, procuramos delimitar algumas especificidades deste processo em cada regiáo, estado e município analisado, assim como explicitar a presença do religioso como elemento de mobilizaçáo e constituição de uma plataforma eleitoral, tanto na disputa por cargos executivos como para os legislativos municipais. Para efeitos gerais, foram considerados todos os candidatos que, de alguma forma, acionaram o seu pertencimento religioso, de forma direta ou indireta, os quais denominamos como religiosos políticos, além dos candidatos ao executivo que buscaram apoio junto aos segmentos religiosos.

Palavras-chave: Religião; Política; Eleiçóes.

1 Os autores deste texto agradecem aos membros do Núcleo de Estudos da Religião (NER/UFRGS) - professores Carlos Alberto Steil, Eduardo Dullo, Marcelo Tadvald e Gustavo Chiesa, assim como os alunos Mariana R. Picolotto, Leonardo Almeida, Jorge Scola, Taylor Aguiar e Maria do Carmo Gonçalves - pelos seus comentários, sugestóes e questionamentos na fase inicial de análise dos dados aqui apresentados.

2 Mestrando do PPGAS/UFRGS e colaborador do Núcleo de Estudos da Religião (NER/ UFRGS). Contato: erico.carvalho@hotmail.com

3 Professor titular do Departamento de Antropologia da Universidade Federal do Rio Grande do Sul e pesquisador do CNPq. Contato: arioro@uol.com.br 


\begin{abstract}
The present work aims to contribute to a national perspective on the problematic of interrelationship between religion and politics field during the electoral process in 2016 in Brazilian capitals. The text has a comparative expository character seeking to privilege the data collected in the field followed by a brief analysis. In this way, we seek to delimit some specificities of this process in each region, state and city analyzed, as well as to explain the presence of the religious as an element of mobilization and constitution of an electoral platform, both in the competition for executive positions as for the municipal city legislatures. In this analysis, we considered all candidates who, in some way, triggered their religious belonging, directly or indirectly, which we call political religious, as well as candidates for the executive who sought support from the religious segments.
\end{abstract}

Keywords: Religion; Politics; Elections. 
A relação entre religião e política no contexto brasileiro tem despertado o interesse de vários cientistas sociais (v.g. Burity, 1997; Oro, 2003a; Oro e Mariano, 2011; Burity e Machado 2006; Machado e Burity 2014; Mariano e Oro, 2016), os quais têm se debruçado, num primeiro nível analítico, especialmente sobre o crescente envolvimento de segmentos evangélicos na política partidária e a mútua instrumentalização do religioso e do político. Sustenta-se que enquanto esta última parece constituir a atualização de uma histórica prática cultural, a primeira envolve razões de ordem prática e simbólica e tende a se impor tão fortemente nas últimas décadas que, segundo J. Burity (1997), pode mesmo inviabilizar uma eleição ${ }^{4}$. Em outro nível analítico, a existência de uma fronteira relativamente tênue entre religião e política - em razão de continuidades, pontes, passagens, trânsitos e apropriações mútuas, ou, segundo as palavras de Séman (2006, p. 19), devido à "canalização de uma mentalidade cosmológica no interior do sistema eleitoral brasileiro e no contexto das capacidades das instituiçóes religiosas de articular o plano político e o religioso" - tem interpelado o conceito clássico de secularização enquanto autonomização das esferas sociais, sobretudo do político em relação ao religioso, com o consequente enfraquecimento da religiáo como força social ${ }^{5}$, e se aproximado da perspectiva proposta por D. Hervieu-Léger,

4 Em suas palavras: "os partidos e candidatos que não levam em consideração os grupos religiosos (leia-se evangélicos) em seu discurso e estratégia correm o risco de se complicarem ou inviabilizarem eleitoralmente" (Burity, 1997, p. 46).

5 Notadamente três sociólogos defendem a noção de secularização enquanto um processo contínuo e irreversível de perda de plausibilidade do religioso no contexto da modernidade. São eles: Bryan Wilson, Peter Berger e Sabino Acquaviva. Para Wilson, a secularizaçáo é um "processo pelo qual o pensamento, práticas e instituiçóes religiosas perdem seu significado para a operação do sistema social" (Wilson, 1998, p. 49). É sobretudo nos campos da política, do comportamento social e técnico-científico, que tal processo é irreversível - embora não ocorra de forma homogênea nos países e nas sociedades - e atinge a organização da sociedade moderna em sua cultura e mentalidade coletiva. Por seu turno, Berger também defende a ideia segundo a qual secularização "é o processo pelo qual setores da sociedade e da cultura são subtraídos à dominação das instituiçôes 
que sustenta ser a secularização um processo de recomposição de "processos múltiplos de redistribuição de significaçôes que ligam intrinsecamente uma a outra a ordem do religioso e o do político" (Hervieu-Léger, 1987, p. 18)

Dentro desta lógica, nota-se ser cada vez mais proeminente a presença de agentes políticos com forte comprometimento com identidades e instituiçóes religiosas ocupando cargos no poder legislativo, e mesmo no executivo, provenientes sobretudo dos segmentos evangélicos, que formam, mesmo que informalmente, "bancadas religiosas", sendo a mais conhecida a Frente Parlamentar Evangélica (FPE) ou, como é popularmente conhecida, a "Bancada Evangélica", a qual, embora não forme um grupo coeso, possui grande capacidade de mobilização ao tratar de temas que concernem valores que afetam a moral religiosa (Tadvald, 2015; Trevisan, 2013). Tais bancadas, mais ou menos organizadas, estão presentes nas três esferas legislativas, ou seja, federal, estadual e municipal, sendo esta última um dos focos desta análise.

Desta forma, este texto possui um caráter expositivo comparativo, analisando a imbricação entre religião e política durante o processo eleitoral de 2016 nas 26 capitais brasileiras, limitando as especificidades deste processo em cada regiáo, estado e município analisado, e explicitando a presença religiosa mobilizada tanto na disputa por cargos executivos quanto para os legislativos municipais. Para efeitos gerais, foram considerados todos os

e símbolos religiosos" (Berger, 1985, p. 119). Nota-se, porém, que o próprio Berger tem revisto, ao menos parcialmente, e nuançado, a sua posição sobre a secularizaçáo, nos moldes referidos em 1985 (Berger, 2000; Mariz, 2000). Enfim, no dizer de Acquaviva, a secularização, enquanto recuo dos valores sagrados, dos mitos e ritos no mundo ocidental industrializado, pode ser percebido tanto do ponto de vista estatístico quanto informativo (Aquaviva, 1961).

6 Em outro momento do mesmo livro, esta autora reforça a ideia de que faz uso do termo secularização não no sentido de declínio ou desaparecimento da religião e sim de recomposição do significado da religião confrontada com a racionalidade. Para ela, secularização é o "[...] processo de reorganização permanente do trabalho da religiáo numa sociedade estruturalmente incapaz de atender as expectativas que precisa suscitar para existir como tal" (Hervieu-Léger, 1987, p. 227).

Debates do NER, Porto Alegre, Ano i 8, N. 32, P. I 5-68, Jul./Dez. 20 I 7 
candidatos que, de alguma forma, acionaram o seu pertencimento religioso, os quais, por esta razão, chamaremos de religiosos políticos, de acordo com uma tipologia proposta anteriormente (Oro, 2003b). São assim considerados os sujeitos detentores de um pertencimento religioso anterior a sua eleição, que se utilizam deste pertencimento como capital político, mesmo que de forma sutil, e que, uma vez eleitos, mantêm o seu vínculo religioso de forma explícita. 7 Portanto, este artigo se propóe a analisar, por um lado, as candidaturas de religiosos, buscando esboçar um quadro das relaçóes entre religiáo e política nas capitais brasileiras e, por outro lado, situar Porto Alegre/RS dentro deste quadro como espaço privilegiado de análise. Deste modo, o texto possui um caráter comparativo, partindo de um ponto específico da geografia nacional, ou seja, do extremo sul do país. Obviamente que os dados aqui apresentados não possuem todos a mesma intensidade de informaçóes, o que acaba por gerar uma assimetria entre os dados de Porto Alegre, mais completos, e os das demais capitais, motivo pelo qual serão apresentados em separado.

Metodologicamente os dados foram construídos a partir da análise do material de campanha de cerca de 17 mil candidatos, assim como suas mídias eletrônicas, além de jornais, revistas e vídeos das mídias locais. Considerando que a explicitação de qualquer identidade ou bandeira política em um processo eleitoral tem como finalidade atingir um público específico, causando uma identificação entre eleitor e candidato, nos propomos a assumir a posição do eleitor que busca um candidato que represente uma religiosidade específica ou um perfil mais complexo associado a uma religião, seja ela afrorreligiosa, católica, evangélica, espírita etc. Da mesma forma, este posicionamento permite acessar um amplo leque de maneiras de acionar uma identidade religiosa, que vai desde a autoafirmaçáo de um vínculo religioso, tal como "sou pastor da igreja..."; passando por afirmaçóes genéricas como "sou afrorreligioso" ou "sou cristão", até formas bastante sutis ou

7 Ao religioso político se contrapóe o político religioso ou político laico, cujo pertencimento religioso não é explícito ou não interfere diretamente em sua atuação política. 
passivas como adoção de linguagem e/ou presença exclusiva em atividades de determinado segmento religioso, ou ainda, como já tratado em outro lugar (Oro; Carvalho, 2015), valendo-se apenas do conhecimento público ou restrito do segmento ao qual pertence. Reafirmamos que a finalidade deste trabalho náo é explicitar o pertencimento religioso de todos os candidatos, mas apenas daqueles que o fizeram em sua campanha eleitoral de forma acessível ou cujo pertencimento é publicamente conhecido, como é o caso de praticamente todas as lideranças religiosas e dos candidatos oficiais. $\mathrm{Da}$ mesma forma, o texto não possui a finalidade de aprofundar as motivaçóes dos candidatos, partidos ou segmentos religiosos.

Cabe ressaltar que o contexto político em que se desenrolou o último pleito eleitoral foi bastante específico, pois a crise política que vinha se gestando desde a reeleição de Dilma Rousseff, em 2014, chegou ao seu auge em 2016, com a sua destituição e uma mudança radical nos planos do governo federal, que adotou medidas econômicas de cunho liberal que implicam em restriçóes dos gastos sociais. Tudo isto conduziu a uma relativa polarização da opinião pública, bastante visível durante esse pleito, com um crescimento do conservadorismo político e um enfraquecimento da esquerda partidária ${ }^{8}$.

Enfim, sem pretender aprofundar os matizes ideológicos dos 38 partidos registrados atualmente no Brasil, importa destacar como importante para a nossa análise a existência de um subgrupo alinhado à direita do espectro ideológico que chamaremos de partidos cristâos, uma vez que possuem como bandeira a defesa de valores do cristianismo ou se propóem a representar diretamente este segmento religioso. São eles: o Partido Trabalhista Cristão (PTC), o Partido Social-Democrata Cristão (PSDC), o Partido Republicano (PR),

8 Considerando ser cada vez mais difícil conceber a esfera política de forma polarizada entre direita e esquerda, estas noçóes serão utilizadas apenas como referentes sem maiores problematizaçóes, sendo considerados os segmentos alinhados à direita como aqueles que defendem o liberalismo econômico e/ou o conservadorismo social, e como alinhados à esquerda aqueles que defendem a equidade de direitos sociais e a redistribuição de renda.

Debates do NER, Porto Alegre, Ano i 8, N. 32, P. I 5-68, Jul./Dez. 20 I 7 
o Partido Social Cristão (PSC) e o Partido Republicano Brasileiro (PRB). Todos estes partidos agregam forte presença do segmento evangélico, mas também da ala conservadora da Igreja Católica, em proporçôes bastante variáveis de acordo com o estado ou a região do país, sendo os dois últimos, PSC e PRB, controlados sobretudo por membros da Assembleia de Deus (AD) e da Igreja Universal do Reino de Deus (IURD), respectivamente. Estes partidos se mostraram importantes na dinâmica eleitoral da maioria das capitais, estando diretamente associados aos votos dos segmentos cristãos. Dito isso, passemos aos dados.

$\mathrm{O}$ artigo está dividido em duas partes. Na primeira, discorremos acerca da relação entre religião e o processo eleitoral em Porto Alegre; na segunda, apresentamos os dados correspondentes às demais capitais brasileiras por regiáo, encerrando com uma breve análise comparativa.

\section{AS ELEIÇÓES 2016 EM PORTO ALEGRE/RS}

Para a prefeitura de Porto Alegre apresentaram-se 9 candidatos. Alinhados à direita do espectro partidário havia Nelson Marchezan (PSDB - Partido Social-Democrata Brasileiro) em uma coligação modesta de 4 partidos, incluindo o PTC, que, mesmo assim, venceu o candidato Sebastião Melo (PMDB - Partido do Movimento Democrático Brasileiro) no segundo turno. Sebastião Melo, por sua vez, foi vice-prefeito na gestão de José Fortunatti, sendo este membro da Igreja Batista Filadélfia, e contou com o apoio de uma grande coligação de 14 partidos, incluindo o PRB e o PSDC. Também concorreram Maurício Dziedricki (PTB - Partido Trabalhista Brasileiro), que ficou em $4^{\circ}$ lugar, com uma coligação de 6 partidos, incluindo o PSC e o PR, e Fábio Ostermann (PSL - Partido Social Liberal), que ficou em $6^{\circ}$ lugar. Já à esquerda apresentaram-se 5 candidatos independentes ou em pequenas coligaçóes. Foram eles: Raul Pont (PT - Partido dos Trabalhadores), que ficou em $3^{\circ}$ lugar, Luciana Genro (PSOL - Partido Socialismo e Liberdade), que ficou em $5^{\circ}$ e Marcelo Chiodo (PV - Partido Verde), Júlio 
Flores (PSTU - Partido Socialista dos Trabalhadores Unificados) e João Rodrigues (PMN - Partido da Mobilização Nacional), que ficaram em 7º, $8^{\circ}$ e $9^{\circ}$ lugar, respectivamente.

Acerca deste processo eleitoral podemos fazer quatro observaçōes. Em primeiro lugar, ocorreu a polarização das candidaturas. Ao contrário das eleiçōes anteriores, não houve coligaçôes entre partidos de direita e de esquerda, como ocorreu em 2012. Em segundo lugar, os partidos cristáos, ou seja, PSC, PRB, PR, PTC e PSDC, se coligaram com partidos da direita. Já a esquerda manteve o seu discurso de respeito à diversidade religiosa, especialmente de defesa das religióes de matriz africana contra a intolerância. Terceiro, a migraçáo destes partidos para as coligaçóes da direita aumentou proporcionalmente as coligaçóes, concentrando os votos. Por último, o contexto político, assim como as mudanças na lei eleitoral', fizeram com que náo houvesse grandes movimentaçôes dos candidatos em busca do voto religioso. Os candidatos de esquerda praticamente náo dialogaram com os segmentos cristãos e os candidatos de direita buscaram apoio diretamente com as lideranças, comparecendo aos templos como visitantes. Como veremos na segunda parte deste texto, estes elementos foram recorrentes na maioria das capitais brasileiras com diferentes intensidades.

Já para a Câmara de Vereadores de Porto Alegre compareceram 581 candidatos que disputaram 36 cadeiras. Destes, ao menos 38 explicitaram o seu pertencimento religioso. Foram 16 evangélicos, 11 católicos $^{10}, 8$ afrorreligiosos, 2 esotéricos e 1 representante da comunidade judaica, como se pode ver no quadro a seguir.

9 Por resolução do TRE (N.o 22.718/2008) ficou proibida a propaganda eleitoral em "bens de uso comum" como cinemas, igrejas, templos, teatros, estádios, mesmo sendo propriedade privada.

${ }^{10}$ Uma vez que o catolicismo durante muito tempo foi a religião hegemônica no Brasil, levando, ainda hoje, grande parte da população a autodeclarar-se católico, mesmo não tendo comprometimento com a instituição religiosa, consideraremos aqui como católicos apenas aqueles candidatos que se autoafirmaram como tal ou que pertencem a alguma organização ou comunidade ligada à Igreja Católica.

Debates do NER, Porto Alegre, Ano i 8, N. 32, P. I 5-68, Jul./Dez. 20 I 7 
Quadro 1 - Candidatos com vínculos religiosos para a Câmara de Vereadores de Porto Alegre

\begin{tabular}{|c|c|c|c|c|c|}
\hline Candidato & Partido & Denominaçáo & Título & Votaçáo & Situaçáo \\
\hline Elizandro Sabino & PTB & Assembleia de Deus & Pastor & 9.845 & Reeleito \\
\hline José Freitas & PRB & IURD & Pastor & 7.728 & Reeleito \\
\hline Alvoni Medina & PRB & IURD & Pastor & 7.712 & Eleito \\
\hline Ramiro Rosário & PSDB & Luterana do Brasil & Membro & 4.676 & Eleito \\
\hline Paulinho Motorista & PSB & Evangélico & Membro & 3.691 & Eleito \\
\hline Letícia Soares & PSB & $\begin{array}{c}\text { Internacional } \\
\text { da Graça }\end{array}$ & Ministra & 3.195 & Náo eleito \\
\hline Claudio Conceicão & DEM & Batista Filadélfia & Membro & 2.887 & Náo eleito \\
\hline Luiza Neves & PDT & Assembleia de Deus & Membro & 2.498 & Não eleito \\
\hline $\begin{array}{l}\text { Hamilton } \\
\text { Sossmeier }\end{array}$ & PSC & Quadrangular & Pastor & 2.481 & Náo eleito \\
\hline $\begin{array}{l}\text { Amâncio } \\
\text { dos Santos }\end{array}$ & PSDB & Evangélico & Pastor & 1.188 & Náo eleito \\
\hline Luciano Silva & PRB & Assembleia de Deus & Pastor & 793 & Náo eleito \\
\hline Helena Daipe & PSC & CAN & Membro & 591 & Náo eleito \\
\hline Andre Maia & PSC & Evangélico & Membro & 589 & Não eleito \\
\hline Tino Moraes & PMDB & $\begin{array}{c}\text { Internacional } \\
\text { da Graça }\end{array}$ & Membro & 454 & Náo eleito \\
\hline Elias Pinheiro & PSB & Assembleia de Deus & Membro & 214 & Não eleito \\
\hline Daniel Velasques & PSC & Evangélico & Membro & 166 & Náo eleito \\
\hline Total & & & & 48.708 & \\
\hline Mauro Zacher & PDT & Católico & Leigo & 13,551 & Reeleito \\
\hline João Carlos Nedel & PP & Católico & Leigo & 5.346 & Reeleito \\
\hline Humberto Goulart & PTB & Católico & Leigo & 4.995 & Reeleito \\
\hline João Bosco Vaz & PDT & Católico & Leigo & 4.993 & Reeleito \\
\hline Cassiá Carpes & PP & Católico & Leigo & 4.963 & Reeleito \\
\hline Adeli Sell & PT & Católico & Leigo & 3.387 & Reeleito \\
\hline Aldacir Oliboni & PT & Católico & Leigo & 3.569 & Eleito \\
\hline $\begin{array}{c}\text { Wambert Di } \\
\text { Lorenzo }\end{array}$ & PROS & Católico & Leigo & 2.906 & Eleito \\
\hline Elói Guimarães & PTB & Católico & Leigo & 1.649 & Náo eleito \\
\hline Arilton Cardoso & PSOL & Católico & Leigo & 990 & Não eleito \\
\hline Roberto Maineri & PSOL & Católico & Leigo & 331 & Náo eleito \\
\hline Total & & & & 46.680 & \\
\hline
\end{tabular}


Quadro 1 - Candidatos com vínculos religiosos para a Câmara de Vereadores de Porto Alegre

\begin{tabular}{|c|c|c|c|c|c|}
\hline Candidato & Partido & Denominaçáo & Título & Votação & Situação \\
\hline Cleiton Silvestre & PDT & Afrorreligioso & Membro & 4.108 & Não eleito \\
\hline Bábà Diba & PT & Afrorreligioso & Babalorixá & 1.700 & Não eleito \\
\hline Glória Cristal & PMDB & Afrorreligiosa & Iyálorixá & 1.130 & Não eleito \\
\hline Juan Savedra & PSL & Afrorreligioso & Membro & 758 & Não eleito \\
\hline Iyá Vera Soares & PT & Afrorreligiosa & Iyálorixá & 619 & Não eleito \\
\hline Jorge de Ogum & PTB & Afrorreligioso & Babalorixá & 409 & Não eleito \\
\hline Nilza de Iemanja & PV & Afrorreligiosa & Iyálorixá & 219 & Não eleito \\
\hline Roberto Seitenfus & PSOL & Afrorreligioso & Membro & 189 & Não eleito \\
\hline Total & & & & $\mathbf{9 . 1 3 2}$ & \\
\hline Márcia Bruxa & PTB & Esotérica & Terapeuta & 153 & Não eleito \\
\hline Izabel L'Aryan & PSC & Esotérica & Terapeuta & 3 & Não eleito \\
\hline Total & & & & $\mathbf{1 5 6}$ & \\
\hline Valter Nagelstein & PMDB & Judaísmo & Membro & 9.300 & Reeleito \\
\hline Total & & & & $\mathbf{9 . 3 0 0}$ & \\
\hline
\end{tabular}

Fonte: Quadro elaborado pelos autores.

\section{EvANGÉLICOS}

Dos 16 candidatos evangélicos, 4 pertenciam à Assembleia de Deus (AD); 2 à Igreja Universal do Reino de Deus (IURD); 2 à Igreja Internacional da Graça de Deus (IIGD); 1 à Batista Filadélfia; 1 à Igreja Quadrangular; 1 à Igreja Luterana do Brasil e 1 ao Centro de Avivamento Para as Naçóes $(\mathrm{CAN})^{11}$. Além destes, outros 4 candidatos apresentaram-se como evangélicos genéricos ${ }^{12}$. A soma dos votos destes candidatos chegou a 48.708 votos. Em 2012, quando ao menos 19 candidatos se apresentaram como evangélicos, os votos obtidos somaram 55.602. Portanto, nas últimas eleiçóes houve uma

11 Tendo obtido o apoio indireto da Igreja Mundial do Poder de Deus através do deputado estadual Missionário Volnei Alves (PR).

12 Nas tabelas o termo "evangélico" será utilizado para identificar todos aqueles cujo pertencimento religioso é acionado de forma vaga ou genérica pelo candidato enquanto "evangélico", "cristão evangélico" ou "cristão", sem identificar alguma denominação. 
redução de 6.894 votos. Cabe ressaltar que em 2012 o candidato João Derly (PC do B - Partido Comunista do Brasil) ex-judoca e membro da Igreja Presbiteriana, foi o mais votado entre todos os candidatos com 14.038 votos. No entanto, se relativizarmos a sua candidatura, que teve como plataforma eleitoral a sua atividade esportiva e não o seu pertencimento religioso, pode-se dizer que o número de votos evangélicos manteve-se relativamente estável. Lembrando, porém, que em muitos casos apresentados a bandeira religiosa náo é a única, nem a principal, mobilizada pelos candidatos. Por outro lado, podemos considerar que o segmento evangélico obteve em 2016 um ligeiro aumento no número de representantes. Agora foram 5 eleitos e $4 \mathrm{em} 2012 .{ }^{13}$

Pode-se notar ainda que, assim como nas eleiçóes anteriores, a IURD elegeu seus dois candidatos oficiais ${ }^{14}$ : o já vereador José Freitas (PRB) e o pastor Alvoni Medina (PRB). Como em outras eleiçóes, na última também ocorreu uma divisão quase perfeita de votos entre eles. Também foi reeleito o candidato oficial da Assembleia de Deus, o pastor Elizandro Sabino (PTB). Isto reforça a ideia de que o modelo de candidatura oficial ${ }^{15}$ no meio evangélico garante boas chances de sucesso dos candidatos, uma vez que a denominação orienta o voto de grande parte de seus fiéis ao depositar o seu carisma institucional nos candidatos oficiais. Em suma, embora o número de candidatos evangélicos tenha diminuído de 19 para 16, o seu desempenho

${ }^{13}$ Em 2012, foram eleitos o já citado João Derly (PC do B), Waldir Canal (PRB), José Freitas (PRB) e Elizandro Sabino (PTB). Paulinho Motorista (PSB) só assumiu a sua identidade evangélica após a sua eleição. Entre 2013 e 2014, Luíza Neves (PDT), da Assembleia de Deus, assumiu a suplência, aumentando este número temporariamente.

${ }^{14}$ Desde 2000, a IURD apresenta e elege dois pastores para a Câmara de Vereadores de Porto Alegre, a saber: Valdir Caetano e Almerindo Filho, em 2000 e 2004, e Waldir Canal e José Freitas, em 2008 e 2012.

15 Tal modelo, implementado fortemente pela IURD, consiste na escolha de um ou mais candidatos pela hierarquia da denominaçáo e a utilizaçáo de toda a sua capacidade de mobilização para elegê-los (Oro, 2003b). Valdir Pedde (2005) mostrou que as candidaturas oficiais da IURD, da Igreja Quadrangular e da Assembleia de Deus, são implementadas de forma variável de acordo com cada denominação, não sendo sempre eficaz. 
se igualou ao das últimas eleições. Já Ramiro Rosário (PSDB) e Paulinho Motorista (PSB) apenas citaram seu pertencimento religioso focando sua campanha em outros elementos.

\section{Católicos}

Dos 11 candidatos católicos que concorreram ao legislativo municipal de Porto Alegre, 8 foram eleitos, todos sendo figuras conhecidas da cena política local. Ao menos 4 deles se apresentaram como sendo declaradamente católicos, a saber: João Carlos Nedel (PP - Partido Progressista), Aldacir Oliboni (PT), Mauro Zacher (PDT) e Wambert Di Lorenzo (PROS). Este último foi eleito para o primeiro mandato. Os demais fazem parte do Grupo de Vereadores Católicos, criado em 2002 pelo falecido Dom Antônio Cheuiche, então responsável pelo Vicariato da Cultura na Arquidiocese de Porto alegre (Lima et al., 2004).

\section{Afrorreligiosos}

Como vemos no quadro abaixo, 8 candidatos se apresentaram como sendo afrorreligiosos, bem acima da média das últimas eleiçóes que girava em torno de 3 candidatos. No entanto, mais uma vez ninguém foi eleito. A soma total dos votos recebidos pelos três primeiros candidatos, se concentrados num único candidato, poderia levá-lo à eleição.

Considerando que quase todos os candidatos estấo filiados a partidos de esquerda ou de direita moderada, percebe-se nos seus discursos de campanha uma constante afirmação de "perigo" e "risco" para as religiōes afro-brasileiras. Entre os 8 candidatos, 3 já haviam concorrido a vereador, erguendo outras bandeiras, como a segurança, no caso de Cleiton Silvestre, o Delegado Cleiton (PDT - Partido Democrático Trabalhista), ou o movimento LGBT, no caso de Glória Cristal (PMDB), Juan Saavedra (PSOL) e Roberto Seitenfus (PSOL). Isto sugere que, para estes candidatos, houve a necessidade de afirmação da bandeira religiosa, o que, por um lado, dá visibilidade ao segmento, mas, por outro, inviabiliza o sucesso eleitoral devido a pulverização dos votos. 
No quadro abaixo apresentamos a performance eleitoral dos candidatos afrorreligiosos nas últimas cinco eleiçôes municipais em Porto Alegre.

Quadro 2 - Candidaturas afrorreligiosas em Porto Alegre (2000-2016)

\begin{tabular}{|c|c|c|c|c|c|}
\hline Candidato & $\mathbf{2 0 0 0}$ & $\mathbf{2 0 0 4}$ & $\mathbf{2 0 0 8}$ & $\mathbf{2 0 1 2}$ & $\mathbf{2 0 1 6}$ \\
\hline Jorge Verardi & 1.994 & 2.014 & - & - & - \\
\hline Áureo Rodrigues & 451 & - & - & - & - \\
\hline Danilo Andrade & 421 & - & - & - & - \\
\hline Iyá Vera Soares & - & 623 & 1.903 & - & 619 \\
\hline Angel Neto & - & 93 & - & - & - \\
\hline Cleiton Silvestre* & - & - & 2.961 & 6.556 & 4.108 \\
\hline Roberto Seitenfus * & & & 110 & - & 189 \\
\hline Cláudio Toralles * & - & - & - & 442 & - \\
\hline Marcelo D'Lyra & - & - & - & 1.002 & - \\
\hline Glória Cristal * & - & - & - & 1.225 & 1.130 \\
\hline Juan Savedra* & - & - & - & - & 758 \\
\hline Bábà Diba & - & - & - & - & 1.700 \\
\hline Jorge de Ogum & - & - & - & - & 409 \\
\hline Nilza de Iemanja & - & - & - & - & 219 \\
\hline Total & $\mathbf{2 . 8 6 6}$ & $\mathbf{2 . 7 3 0}$ & $\mathbf{4 . 9 7 4}$ & $\mathbf{9 . 2 2 5}$ & $\mathbf{9 . 1 3 2}$ \\
\hline
\end{tabular}

* Candidatos que não concentraram suas campanhas na bandeira afrorreligiosa.

Fonte: Quadro elaborado pelos autores.

De forma minoritária, mas também presente na eleição de 2016, houve duas candidatas que se apresentaram como Terapeutas Holísticas. Ambas não tiveram uma votação expressiva. Também tivemos um candidato representando a comunidade judaica de Porto Alegre, Valter Nagelstein (PMDB), figura bastante conhecida no meio político porto-alegrense e alinhado com o movimento sionista. Reelegeu-se nesta eleição para o seu terceiro mandado.

Como podemos observar, foram 14 os candidatos religiosos eleitos: 5 evangélicos, 8 católicos e 1 judeu, constituindo, mesmo que informalmente, uma bancada religiosa, formada sobretudo por vereadores cristãos, a qual, como já se tornou recorrente na política nacional, possui importante poder de mobilização em disputas envolvendo questôes que atingem a moral cristá. 


\section{AS ELEIÇÓES NAS CAPITAIS BRASILEIRAS}

Em uma perspectiva nacional, focando nas 26 capitais brasileiras, observamos um fortalecimento da direita partidária, uma vez que os candidatos da esquerda só conquistaram seis prefeituras, não chegando nem ao segundo turno na maioria dos casos. O PSDB venceu em 7 capitais (São Paulo, Teresina, Belém, Maceió, Manaus, Porto Velho e Porto Alegre), o PMDB em 4 (Boa Vista, Cuiabá, Florianópolis e Goiânia), o PDT em 3 (Natal, Fortaleza e São Luís), o PSB (Partido Socialista Brasileiro) e o PSD (Partido Social-Democrata) venceram em duas (Palmas e Recife; Campo Grande e João Pessoa, respectivamente) e PT, DEM (Democratas), PC do B, PHS, PMN (Partido da Mobilização Nacional), REDE (Rede Sustentabilidade) e PRB, ficaram com 1 capital cada (Rio Branco, Salvador, Aracaju, Belo Horizonte, Curitiba, Macapá e Rio de Janeiro, respectivamente).

A seguir, visando salientar mais claramente as especificidades locais de cada capital, assim como os contextos religiosos regionais, discorremos acerca de cada regiáo em separado. Para efeitos gerais, só serão citados os candidatos com uma votação expressiva, assim como aqueles que mobilizaram os meios religiosos ou se associaram aos "partidos cristáos".

Regiẫo Sul

A região sul possui a segunda menor porcentagem de evangélicos do país, com 20\%. No entanto, enquanto Porto Alegre/RS conta com 11,6\% e Florianópolis/SC com 12,8\%, Curitiba/PR alcança 24\% de evangélicos, ou seja, acima da média nacional. Tal divisão se reflete na presença evangélica na política. Ela é modesta em Porto Alegre e em Florianópolis, mas é marcante em Curitiba. Passemos aos dados.

Assim como ocorreu em Porto alegre, em Curitiba/PR a disputa eleitoral foi bastante acirrada, com uma boa distribuição do voto evangélico e dos partidos coligados, elegendo-se Rafael Grecca (PMN - Partido da Mobilização Nacional) no segundo turno, com 53,2\% dos votos, contando 
com o apoio de 7 partidos incluindo o PSDC, além de ter obtido um amplo apoio da Assembleia de Deus, através do deputado federal e pastor Hidekazu Takayama (PSC-PR) ${ }^{16}$. Em segundo lugar, chegou Ney Leprevost (PSD - Partido Social-Democrata), com o apoio de 6 partidos incluindo PSC e PTC. Em 3o lugar, ficou Gustavo Fruet (PDT), que contou com o apoio do PRB, obtendo $20 \%$ dos votos. Seu vice foi Paulo Salamuni (PV), ex-vereador que possui ligaçóes com a Igreja Católica. O 40 lugar foi ocupado por Maria Vitória (PP), com o apoio do PR. Requião Filho (PMDB) ficou em $5^{\circ}$; seu vice Jorge Bernardi (REDE) é membro da Igreja Presbiteriana. Em $8^{\circ}$ chegou Xênia Mello (PSOL) que, embora tenha ficado em último lugar, foi a única candidata a se declarar afrorreligiosa.

Já para a Câmara de Vereadores de Curitiba apresentaram-se 1.049 candidatos para 38 vagas, dos quais cerca de 45 explicitaram a sua identidade religiosa. Foram 25 evangélicos e 20 católicos. Conforme mostra o quadro 3, os evangélicos elegeram 8 vereadores. Já os católicos elegeram ao menos 18 vereadores ${ }^{17}$.

Quadro 3 - Religiosos políticos eleitos para a Câmara de Vereadores de Curitiba

\begin{tabular}{|c|c|c|c|c|c|}
\hline Candidato & Partido & Denominaçáo & Título & Votaçáo & Situaçáo \\
\hline Osias Moraes & PRB & IURD & Pastor & 8.239 & Eleito \\
\hline Antônio do Carmo & PDT & Assembleia de Deus & Membro & 7.549 & Reeleito \\
\hline Thiago Ferro & PSDB & Sara Nossa Terra & Bispo & 6.298 & Eleito \\
\hline Cristiano Santos & PV & Evangélico & Membro & 6.151 & Reeleito \\
\hline Wolmir Aguiar & PSC & Quadrangular & Membro & 5.182 & Eleito \\
\hline Noêmia Rocha & PMDB & Assembleia de Deus & Membro & 4.615 & Reeleita \\
\hline Cacá Pereira & PSDC & Evangélico & Membro & 3.728 & Reeleito \\
\hline Ezequias Barros & PRP & Brasil Para Cristo & Membro & 3.006 & Eleito \\
\hline Serginho do Posto & PSDB & Católico & Leigo & 11,272 & Reeleito \\
\hline
\end{tabular}

${ }^{16}$ Disponível em: <http://www.bemparana.com.br/politicaemdebate/index.php/2016/08/09/ greca-e-os-evangelicos/>. Acesso em: $26 \mathrm{dez} .2016$.

${ }^{17}$ Segundo levantamento de Vasconcelos, Magalhães e Castro (2013), no ano de 2013, $58 \%$ dos vereadores de Curitiba eram católicos, $29 \%$ eram evangélicos, $3 \%$ ecumênicos e $10 \%$ não informaram o seu pertencimento religioso. 
Quadro 3 - Religiosos políticos eleitos para a Câmara de Vereadores de Curitiba

\begin{tabular}{|c|c|c|c|c|c|}
\hline Candidato & Partido & Denominaçáo & Título & Votaçáo & Situaçáo \\
\hline Jairo Marcelino & PSD & Católico & Leigo & 8,865 & Reeleito \\
\hline Pierpaolo Petruzziello & PTB & Católico & Leigo & 7,868 & Reeleito \\
\hline Mauro Ignácio & PSB & Católico & Leigo & 7,721 & Reeleito \\
\hline Felipe Braga Cortes & PSDB & Católico & Leigo & 7,708 & Reeleito \\
\hline Helio Wirbiski & PPS & Católico & Leigo & 7,618 & Reeleito \\
\hline Tito Zeglin & PDT & Católico & Leigo & 7,447 & Reeleito \\
\hline Dona Lourdes & PSB & Católica & Leiga & 7,142 & Reeleita \\
\hline Julieta Reis & DEM & Católica & Leigo & 6,821 & Reeleita \\
\hline Sabino Picolo & DEM & Católico & Leigo & 6,565 & Reeleito \\
\hline Cristiano Santos & PV & Católico & Leigo & 6.151 & Reeleito \\
\hline Tico Kuzma & PSB & Católico & Leigo & 6,113 & Reeleito \\
\hline Marcos Vieira & PDT & Católico & Leigo & 5,980 & Eleito \\
\hline Rogerio Campos & PSC & Católico & Leigo & 5,748 & Eleito \\
\hline Geovane Fernandes & PTB & Católico & Leigo & 5.434 & Reeleito \\
\hline Maria Manfron & PP & Católica & Leiga & 4,633 & Eleita \\
\hline Bruno Pessuti & PSC & Católico & Leigo & 4,562 & Reeleito \\
\hline Oscalino de Melo & PTN & Católico & Leigo & 3.427 & Eleito \\
\hline
\end{tabular}

Fonte: Quadro elaborado pelos autores.

Já em Florianópolis/SC, Gean Loureiro (PMDB) foi eleito prefeito com 50,2\% dos votos, contando com o apoio de uma grande coligação de 15 partidos, incluindo o PRB, PTC, PSC e PR. Em 2o lugar chegou Ângela Amin (PP). Para as 23 vagas da Câmara de Vereadores de Florianópolis apresentaram-se 363 candidatos, dos quais ao menos 8 explicitaram o seu pertencimento religioso, sendo 5 evangélicos, 1 católico, 1 afrorreligioso e 1 esotérico. A cidade possui a especificidade de não possuir uma grande porcentagem de evangélicos (12,81\%) e um alto número de espíritas $(7,4 \%)$. Isto explica o fato de que na capital catarinense foi eleito apenas um vereador evangélico, o pastor Claudinei Marques (PRB), da IURD, com 3.346 votos, sucedendo Jerônimo Alves, bispo da mesma denominaçấo, eleito em $2012^{18}$.

${ }^{18}$ Ainda em 2012 foi eleito o pastor da Igreja Quadrangular, Aldérico Furlan (PSC). 
Os dados que precedem mostram que a região sul apresenta uma diversidade de contextos. Porto Alegre é a capital brasileira com a menor porcentagem de evangélicos (11,6\%); mesmo assim, mantêm um pequeno grupo de vereadores deste segmento, os quais, quando unidos aos vereadores católicos, formam um grupo que, caso se juntem, passam a ter um peso considerável nas decisões legislativas. Florianópolis, por sua vez, possui a particularidade geográfica de se localizar numa ilha e basear a sua economia no turismo. O perfil social dos seus moradores parece sugerir tratar-se de indivíduos que tendem a separar política e religião. Daí o reduzido número de religiosos políticos eleitos. Já em Curitiba os dados indicam uma tendência contrária. Há uma grande preocupação com o pertencimento religioso, principalmente por parte dos católicos, o que náo implica necessariamente em um número maior de católicos na Câmara de Vereadores do que em outras capitais; indica, antes, uma maior necessidade de afirmaçáo desta identidade perante os eleitores, considerando sobretudo o avanço do segmento evangélico na capital paranaense.

\section{Regiâo Sudeste}

O sudeste mantêm uma certa regularidade entre as suas capitais, com uma presença marcante de evangélicos, principalmente do segmento neopentecostal, que náo só elegeram um de seus membros para o executivo do Rio de Janeiro, como também marcam presença nos legislativos municipais. Entre os católicos, poucos explicitaram o seu pertencimento religioso. A maioria dos que assim procederam mostraram-se ligados ao movimento carismático. Além disso, a região possui o maior colegiado eleitoral do país, com 43,2\% dos eleitores (mais de 61 milhóes de eleitores), sendo um espaço onde literalmente se define a política nacional. Desta forma, é um fato marcante a eleição do senador e Bispo da IURD, Marcelo Crivella (PRB) para a prefeitura do Rio de Janeiro/RJ, vencendo Marcelo Freixo (PSOL), que chegou, novamente, em segundo lugar. Crivella acionou um discurso laico bastante adaptado às contingências do momento, pouco lembrando 
ser um neopentecostal e membro da hierarquia da IURD. Acenou aos afrorreligiosos que iria governar "para todos" e buscou aproximar-se da Igreja Católica, visitando o Cardeal Dom Orani Tempesta, episódio que posteriormente foi divulgado amplamente, gerando protestos da diocese, que declarou publicamente não apoiar o candidato ${ }^{19}$ Crivella também recebeu, principalmente no segundo turno, amplo apoio dos segmentos evangélicos, incluindo o Pastor Silas Malafaia, líder da Assembleia de Deus Vitória em Cristo.

No Rio de Janeiro também concorreu ao cargo Pedro Paulo Carvalho (PMDB), que obteve o $3^{\circ}$ lugar, com $16,12 \%$, embora tivesse contado com o apoio de 14 partidos, incluindo o PSDC e o PTC, e tenha tentado se aproximar do eleitorado evangélico, frequentando cultos da $\mathrm{AD}$ Madureira, da AD Vitória em Cristo e da Igreja mundial do Poder de Deus $(\mathrm{IMPD})^{20}$. Já em $4^{\circ}$ lugar, com $14 \%$ dos votos, chegou Flávio Bolsonaro (PSC), membro da Igreja Batista e filho do polêmico deputado federal Jair Bolsonaro (PSC-RJ).

Para as 51 vagas da Câmara de Vereadores do Rio de janeiro apresentaram-se 1.507 candidatos, dos quais ao menos 52 explicitaram o seu pertencimento religioso, sendo 26 evangélicos, 17 católicos, 7 afrorreligiosos e 2 representantes da comunidade judaica, conforme mostra o quadro 4. Elegeram-se 9 evangélicos, 2 a mais do que em 2012, 9 católicos e 2 representantes do judaísmo. É digno de nota que o candidato mais votado, Carlos Bolsonaro (PSC), visto o pertencimento religioso do irmão Flávio, e a recente conversão do pai ao pentecostalismo, apenas se declarou como cristâo. Já o vereador reeleito Renato Moura (PDT) fez questão de deixar claro que provém de uma família evangélica, cujo pai era pastor, sendo assim considerado como evangélico.

${ }^{19}$ Disponível em: <http://oglobo.globo.com/brasil/igreja-rejeita-panfleto-com-foto-decrivella-dom-orani-20149469>. Acesso em: 10 nov. 2016.

${ }^{20}$ Disponível em: <http://oglobo.globo.com/brasil/pedro-paulo-vai-cultos-para-seaproximar-de-evangelicos-20155676>. Acesso em: 10 nov. 2016.

Debates do NER, Porto Alegre, Ano i 8, N. 32, P. I 5-68, Jul./Dez. 20 I 7 
Quadro 4 - Religiosos políticos eleitos para a Câmara de Vereadores no Rio de Janeiro

\begin{tabular}{|c|c|c|c|c|c|}
\hline Candidato & Partido & Denominaçáa & Título & Votaçáo & Situaçáo \\
\hline João M. de Jesus & PRB & IURD & Bispo & 31.516 & Reeleito \\
\hline Alexandre Isquierdo & DEM & Assembleia de Deus & Membro & 24.701 & Reeleito \\
\hline Tânia Bastos & PRB & IURD & Membro & 22.930 & Reeleita \\
\hline Inaldo Silva & PRB & IURD & Bispo & 22.735 & Eleito \\
\hline Verônica Costa & PMDB & Evangélica & Membro & 19.946 & Reeleito \\
\hline Renato Moura & PDT & Evangélico & Membro & 13.572 & Reeleito \\
\hline Jorge Manaia & SD & Evangélico & Membro & 13,249 & Eleito \\
\hline Eliseu Kessler & PSD & Assembleia de Deus & Membro & 10.777 & Eleito \\
\hline Otoni de Paula Jr & PSC & Assembleia de Deus & Pastor & 7,801 & Eleito \\
\hline Tarcísio Motta & PSOL & Católico & Leigo & 90.473 & Eleito \\
\hline César Maia & DEM & Católico & Leigo & 71.468 & Reeleito \\
\hline Vera Lins & $\mathrm{PP}$ & Católica & Leiga & 36.117 & Reeleita \\
\hline Carlo Caiado & DEM & Católico & Leigo & 28.122 & Reeleito \\
\hline Jairo Souza Santos & PMDB & Católico & Leigo & 26.047 & Reeleito \\
\hline $\begin{array}{l}\text { Marcelino } \\
\text { D'Almeida }\end{array}$ & PP & Católico & Leigo & 24.116 & Reeleito \\
\hline $\begin{array}{l}\text { Reimont Luiz } \\
\text { Otoni }\end{array}$ & PT & Católico & Padre & 19.626 & Reeleito \\
\hline Rogério Rocal & PTB & Católico & Leigo & 15,055 & Reeleito \\
\hline Cláudio Castro & PSC & Católico & Leigo & 10.262 & Reeleito \\
\hline Teresa Bergher & PSDB & Judaísmo & Membro & 30.566 & Reeleita \\
\hline Marcelo Arar & PTB & Judaísmo & Membro & 16.230 & Reeleito \\
\hline Carlos Bolsonaro & PSC & Cristão & Membro & 106.657 & Reeleito \\
\hline
\end{tabular}

Fonte: Quadro elaborado pelos autores.

Em São Paulo/SP, o empresário João Dória (PSDB) foi eleito prefeito no primeiro turno com $53.2 \%$ dos votos, em uma coligação de 13 partidos entre eles o PTC. O candidato ganhou o apoio do eleitorado cristáo ao propor uma parceria com entidades religiosas evangélicas e católicas em temas relacionados ao serviço social. Fernando Haddad (PT) não foi reeleito, ficando em segundo lugar, com $16.7 \%$ dos votos. Contou com o apoio do PR. Celso Russomano (PRB) chegou novamente em 30 lugar, com 13.6\% dos votos, $8 \%$ a menos do que em 2012, mesmo tendo recebido amplo 
apoio da IURD e de pequenas denominaçóes neopentecostais, além do apoio do PSC, dividindo, assim, o voto evangélico com Dória, embora este seja declaradamente católico. Já em 4o lugar ficou Marta Suplicy (PMDB) que, juntamente com Haddad, foi rejeitada pelo eleitorado evangélico principalmente por sua posição a favor do Movimento LGBT. Ainda concorreu Levy Fidelix (PRTB), católico conservador, que ficou em $8^{\circ}$ lugar, e João Bico (PSDC), que chegou em 90 lugar.

Para a Câmara de Vereadores de São Paulo apresentaram-se 1.202 candidatos para 55 vagas. Ao menos 58 candidatos explicitaram o seu pertencimento religioso. Foram 36 evangélicos, 10 católicos, 8 judeus, 2 afrorreligiosos, 1 espírita e 1 budista. Conforme mostra o quadro abaixo, elegeram-se 17 evangélicos, sendo 15 vinculados a denominaçóes e 2 somente ao campo evangélico, 7 católicos, 1 representante da comunidade judaica e 1 candidata budista.

Quadro 5 - Religiosos políticos eleitos para a Câmara de Vereadores de São Paulo

\begin{tabular}{|c|c|c|c|c|c|}
\hline Candidato & Partido & Denominaçáo & Título & Votaçáo & Situaçáo \\
\hline Eduardo Tuma & PSDB & Bola de Neve & Presbítero & 70.273 & Reeleito \\
\hline Souza Santos & PSD & IURD & Pastor & 55.924 & Reeleito \\
\hline Eliseu Gabriel & PSB & Presbiteriana & Membro & 52.355 & Reeleito \\
\hline Atílio Francisco & PRB & IURD & Bispo & 46.961 & Reeleito \\
\hline Patrícia Bezerra & PSDB & Comunidade da Graça & Membro & 45.285 & Reeleita \\
\hline João Jorge & PSDB & Assembleia de Deus & Pastor & 42.4040 & Eleito \\
\hline Edir Sales & PSD & Evangélica & Membro & 39.062 & Reeleita \\
\hline André Santos & PRB & IURD & Pastor & 37.393 & Eleito \\
\hline Sandra Tadeu & DEM & Internacional da Graça & Membro & 34.182 & Reeleita \\
\hline Rute Costa & PSD & Assembleia de Deus & Membro & 33.999 & Eleita \\
\hline Noemi Nonato & PR & AD Madureira & Cantora & 32.116 & Eleita \\
\hline Gilberto N. Junior & PSC & Assembleia de Deus & Membro & 30,382 & Eleito \\
\hline Adriana Ramalho & PSDB & Evangélica & Membro & 29.756 & Reeleita \\
\hline David Soares & DEM & Internacional da Graça & Pastor & 24,892 & Reeleito \\
\hline Rinaldi Digiglio & PRB & Quadrangular & Pastor & 20.916 & Eleito \\
\hline Ricardo Nunes & PMDB & Católico & Leigo & 54,692 & Reeleito \\
\hline Aurélio Nomura & PSDB & Católico & Leigo & 41.954 & Reeleito \\
\hline Gilson Barreto & PSDB & Católico & Leigo & 38.564 & Reeleito \\
\hline Toninho Paiva & PR & Católico & Leigo & 35,219 & Reeleito \\
\hline
\end{tabular}


Quadro 5 - Religiosos políticos eleitos para a Câmara de Vereadores de São Paulo

\begin{tabular}{|c|c|c|c|c|c|}
\hline Candidato & Partido & Denominaçáo & Título & Votação & Situaçáo \\
\hline Juliana Cardoso & PT & Católica & Leiga & 34.949 & Reeleita \\
\hline Jair Tatto & PT & Católico & Leigo & 30,989 & Reeleito \\
\hline Toninho Vespoli & PSOL & Católico & Leigo & 16.012 & Reeleito \\
\hline Soninha & PPS & Budista & Praticante & 40.113 & Eleita \\
\hline Daniel Annenberg & PSDB & Judaísmo & Membro & 36,983 & Eleito \\
\hline
\end{tabular}

Fonte: Quadro elaborado pelos autores.

Em Belo Horizonte/MG, Alexandre Kalil (PHS), ex-presidente do Atlético Mineiro e empresário da construção civil, não investiu na conquista do voto religioso, chegando a declarar, em tom jocoso, que achava "igreja um saco" ${ }^{21}$. Foi eleito prefeito da cidade no segundo turno com 52,98\% dos votos, contando somente com o apoio do REDE (Rede Solidariedade) e do PV. Já o candidato preferido dos evangélicos João Leite (PSDB), chegou em $2^{\circ}$ lugar, apesar do apoio de 5 partidos, incluindo o PRB. Leite é membro da Igreja Batista de Belo Horizonte e ex-jogador de futebol, sendo um dos fundadores do grupo "Atletas de Cristo", em 1981. Ficou conhecido como "Goleiro de Deus". Durante suas campanhas ambos se encontraram com líderes evangélicos, incluindo o comparecimento na Convenção de Pastores da Igreja Batista Getsêmani, uma das mais importantes da capital mineira, em 25 de outubro de $2016^{22}$. Além destes candidatos é digno de nota a candidatura de Rodrigo Pacheco (PMDB), que teve como vice Vanderlei Miranda (PMDB), pastor da Igreja Batista Lagoinha, da família Valadão. Obteve $10 \%$ dos votos, chegando em 3 lugar. Sua candidatura contou com o apoio do PSC e do PTN. Também concorreu Eros Biondini (PROS), deputado federal e liderança da Renovação Carismática Católica (RCC). Chegou em 7o lugar. Marcelo Álvaro Antônio (PR), que teve o apoio do PSDC, ficou em $10^{\circ}$ lugar.

${ }^{21}$ Disponível em: <http://brasil.elpais.com/brasil/2016/10/30/politica/1477859629_ 540297.html>. Acesso em: 12 dez. 2016.

22 Disponível em: <http://www.metrojornal.com.br/nacional/eleicoes-2016-3/candidatosse-encontram-com-pastores-evangelicos-319721>. Acesso em: 10 nov. 2016. 
Para a Câmara de Vereadores de Belo Horizonte apresentaram-se 1.365 candidatos às 41 cadeiras. Ao menos 60 candidatos explicitaram o seu vínculo religioso. Foram 46 evangélicos, 11 católicos e 3 afrorreligiosos. Como mostra o quadro abaixo, foram eleitos 13 evangélicos, sendo que 7 dos 9 vereadores que compunham a "bancada evangélica" em 2012 foram reeleitos. Também foram eleitos 8 candidatos católicos.

Quadro 6 - Religiosos políticos eleitos para a

Câmara de Vereadores de Belo Horizonte

\begin{tabular}{|c|c|c|c|c|c|}
\hline Candidato & Partido & Denominaçáo & Título & Votaçáo & Situaçáo \\
\hline $\begin{array}{c}\text { Juninho } \\
\text { Los Hermanos }\end{array}$ & PROS & Evangélico & Membro & 12,866 & Reeleito \\
\hline Fernando Luiz & PSB & IURD & Bispo & 12.645 & Reeleito \\
\hline Jorge santos & PRB & IURD & Pastor & 8.503 & Reeleito \\
\hline Marilda Portela & PRB & Batista & Membro & 8.457 & Eleita \\
\hline Juliano Lopes & PTC & Evangélico & Membro & 7,714 & Reeleito \\
\hline Henrique Braga & PSDB & Assembleia de Deus & Pastor & 6.939 & Reeleito \\
\hline Autair Gomes & PSC & Quadrangular & Pastor & 6,615 & Reeleito \\
\hline Elvis Côrtes & PSD & Batista & Pastor & 4,867 & Reeleito \\
\hline Jair di Gregório & $\mathrm{PP}$ & Assembleia de Deus & Cantor & 4,621 & Eleito \\
\hline Cláudio Duarte & PMN & Adventista & Membro & 4.513 & Eleito \\
\hline Eduardo Guimarães & PTN & Batista & Membro & 4.441 & Eleito \\
\hline Fernando Borja & PTdoB & Batista & Pastor & 4.384 & Eleito \\
\hline Irlan Melo & PR & Presbiteriana & Pastor & 4.047 & Eleito \\
\hline $\begin{array}{l}\text { Prof. Wendel } \\
\text { Mesquita }\end{array}$ & PSB & Católico & Leigo & 13.277 & Reeleito \\
\hline Alvaro Damião & PSB & Católico & Leigo & 10.869 & Eleito \\
\hline Orlei Pereira & PT do B & Católico & Leigo & 6.133 & Reeleito \\
\hline Pedrão do Depósito & PPS & Católico & Leigo & 5.529 & Eleito \\
\hline
\end{tabular}

Fonte: Quadro elaborado pelos autores.

Em Vitória/ES, dos 5 candidatos ao executivo municipal, 3 se coligaram em três grandes blocos, tendo sido a disputa vencida no segundo turno por Luciano Rezende (PPS), um candidato de esquerda que se reelegeu com $51,1 \%$ dos votos. Contou com o apoio de 11 partidos, incluindo o PSDC e o PRB. Rezende manteve um bom relacionamento com o meio evangélico 
desde o seu primeiro mandato, inclusive participando de cultos organizados por pastores na prefeitura de Vitória e mantendo como seu grande apoiador o Senador Magno Malta (PR-ES), pastor da Igreja Batista. Em 2o lugar chegou Amaro Neto (SD), que contou com o apoio de 9 partidos, entre eles o PTC e o PR. O $3^{\circ}$ colocado foi Welington Coimbra (PMDB), que teve $\mathrm{o}$ apoio de 6 partidos, incluindo o PSC, ambos sem grande expressão no meio evangélico.

Para a Câmara de Vereadores de Vitória apresentaram-se 240 candidatos para 15 vagas. Ao menos 17 deles acionaram o seu pertencimento religioso. Foram 11 evangélicos, 3 católicos e 1 afrorreligioso. Destes foram eleitos 2 candidatos que se apresentaram como cristãos, 3 como evangélicos e 2 como católicos.

Quadro 7 - Religiosos políticos eleitos para a Câmara de Vereadores de Vitória

\begin{tabular}{|c|c|c|c|c|c|}
\hline Candidato & Partido & Denominaçáo & Título & Votaçáo & Situaçáo \\
\hline Fabrício Gandini & PPS & Batista & Membro & 7.611 & Reeleito \\
\hline Davi Esmael & PSB & Batista & Membro & 5.165 & Reeleito \\
\hline Leonil Dias & PPS & Evangélico & Cantor & 3.577 & Eleito \\
\hline Nathan Medeiros & PSB & Cristão & Membro & 3.316 & Eleito \\
\hline Wanderson Marinho & PSC & Cristão & Membro & 2.208 & Reeleito \\
\hline Denninho & PPS & Católico & Leigo & 6.167 & Eleito \\
\hline Luiz Paulo Amorim & PV & Católico & Leigo & 1.696 & Reeleito \\
\hline
\end{tabular}

Fonte: Quadro elaborado pelos autores.

\section{Regiáo Centro-oeste}

Em Goiânia/GO o senador Î́ris Rezende (PMDB), membro da Igreja Cristá Evangélica, elegeu-se no segundo turno como prefeito da cidade, com $57,7 \%$ dos votos. Contou com o apoio do PTC e de várias denominaçôes evangélicas, entre elas a Igreja Mundial do Poder de Deus, além de contar com a simpatia dos católicos. ${ }^{23} \mathrm{Em} 2^{\circ}$ lugar, chegou Vanderlan Cardoso

${ }^{23}$ Disponível em: <http://www.ronaldocaiado.com.br/2016/10/iris-e-caiado-visitamigrejas-evangelicas/>. Acesso em: 12 nov. 2016. 
(PSB), da Assembleia de Deus, que contou com o apoio de 11 partidos, incluindo o PSC, PSDC e PRB. Waldir Soares (PR) ficou em 30 lugar, com $10 \%$ dos votos. O vereador e católico militante da RCC, Francisco Junior (PSD), chegou em 4o lugar e Adriana Acorcci (PT) em $5^{\circ}$ lugar, esta tendo o vereador Deivison Costa (PT do B), membro da Assembleia de Deus, como candidato a vice-prefeito.

Para a Câmara de Vereadores de Goiânia apresentaram-se 681 candidatos para as 35 vagas. Ao menos 29 acionaram o seu pertencimento religioso. Destes 21 são evangélicos e 7 são católicos. Foram eleitos 5 evangélicos, mesmo número da eleição anterior, 5 católicos, além de 1 que se apresentou como cristão.

Quadro 8 - Religiosos políticos eleitos para a Câmara de Vereadores de Goiânia

\begin{tabular}{|c|c|c|c|c|c|}
\hline Candidato & Partido & Denominaçáo & Título & Votaçáo & Situaçáo \\
\hline Rogério Cruz & PRB & IURD & Pastor & 8.312 & Reeleito \\
\hline Oséias Varão & PSB & Assembleia de Deus & Pastor & 6.171 & Eleito \\
\hline Priscilla Tejota & PSD & Manancial da Vida & Membro & 4.807 & Eleita \\
\hline Leia Klebia & PSC & Assembleia de Deus & Membro & 3.367 & Eleita \\
\hline Cabo Senna & PRP & Adventista & Membro & 2.795 & Eleito \\
\hline Anselmo Pereira & PSDB & Católico & Leigo & 7,504 & Reeleito \\
\hline Welington Peixoto & PMDB & Católico & Leigo & 6.513 & Reeleito \\
\hline Kleibe Morais & PSDC & Católico & Leigo & 5.818 & Eleito \\
\hline Tiaózinho Porto & PROS & Católico & Leigo & 4.878 & Eleito \\
\hline Paulo Magalhães & SD & Católico & Leigo & 4.482 & Reeleito \\
\hline Carlin Café & PPS & Cristão & Membro & 7.392 & Reeleito \\
\hline
\end{tabular}

Fonte: Quadro elaborado pelos autores.

Em Campo Grande/MS a disputa foi mais fragmentada e com forte presença evangélica. Marquinhos Trad (PSD), membro da Igreja Atos e Justiça, elegeu-se no segundo turno com 58,7\% dos votos, contando com o apoio de sete partidos. Sua vice, Adriane Lopes (PEN), também é evangélica. Em $2^{\circ}$ lugar ficou Rose Modesto (PSDB), da Igreja Nosso Senhor Jesus Cristo, contando com o apoio de 5 partidos, incluindo o PRB e o PR. Em 3o lugar chegou Alcides Bernal (PP) com o apoio do PTC, e em $4^{\circ}$ o Coronel Davi 
dos Santos (PSC). O PROS lançou Lauro Davi como candidato próprio. Sua vice, Márcia Mega (PROS), é pastora da Igreja Missionária Comunidade em Cristo. Chegaram em $10^{\circ}$ lugar. O PSDC também lançou candidato próprio, Elizeu Amarilla, que ficou em $13^{\circ}$ lugar.

Para a Câmara de Vereadores de Campo Grande apresentaram-se 631 candidatos para as 35 vagas. Ao menos 24 deles explicitaram o seu pertencimento religioso. Foram 19 evangélicos e 5 católicos, elegendo-se 6 evangélicos ${ }^{24}$ e 4 católicos, conforme mostra o quadro a seguir.

Quadro 9-Religiosos políticos eleitos para a

Câmara de Vereadores de Campo Grande

\begin{tabular}{|c|c|c|c|c|c|}
\hline Candidato & Partido & Denominaçáo & Título & Votaçáo & Situaçáo \\
\hline Gilmar da Cruz & PRB & IURD & Pastor & 5.419 & Reeleito \\
\hline Papy & SD & Igreja El Shaddai & Membro & 4.152 & Eleito \\
\hline Júnior Longo & PSDB & Assembleia de Deus & Membro & 4.022 & Eleito \\
\hline Roberto Santana & PRB & Assembleia de Deus & Presbítero & 3.649 & Eleito \\
\hline Dr. Antonio Cruz & PSDB & Assembleia de Deus & Pastor & 3.380 & Reeleito \\
\hline Jeremias Flores & PT do B & Assembleia de Deus & Pastor & 2.930 & Eleito \\
\hline Prof. João Rocha & PSDB & Católico & Leigo & 4.134 & Reeleito \\
\hline Paulo Siufi & PMDB & Católico & Leigo & 2.610 & Reeleito \\
\hline Dharleng Campo & PP & Católico & Leiga & 2.591 & Eleita \\
\hline Eduardo Romero & REDE & Católico & Leigo & 2.220 & Reeleito \\
\hline
\end{tabular}

Fonte: Quadro elaborado pelos autores.

Em Cuiabá/MT Emanuel Pinheiro (PMDB) foi eleito prefeito no segundo turno com $60.41 \%$, tendo obtido o apoio do PSC, do PR, do PTC e de mais 7 partidos. O candidato garantiu o apoio de algumas denominaçóes como a Igreja Batista e a Assembleia de Deus, através de um dos seus membros, o deputado federal Victório Galli (PSC-MS). Wilson Santos (PSDB) chegou em 2o lugar em uma coligação de 12 partidos, incluindo o PSDC. Recebeu o apoio de pequenas denominaçóes evangélicas. O PRB lançou Serys Slhessarenko que embora tendo se declarado católica, foi

${ }^{24} \mathrm{Na}$ legislatura anterior, somando os suplentes, os vereadores evangélicos chegaram a 10. 
fortemente associada à IURD, imagem da qual tentou se desvincular, sem, no entanto, afastar os membros da denominação. Acabou em $5^{\circ}$ lugar, com $3.22 \%$ dos votos. $^{25}$

Para a Câmara de Vereadores de Cuiabá apresentaram-se 443 candidatos para 25 vagas, dos quais 16 explicitaram a sua vinculação religiosa. Foram 12 evangélicos, 3 católicos e 1 que se declarou cristão. Elegeram-se 4 evangélicos, os 3 católicos e o cristão. ${ }^{26}$

Quadro 10 - Religiosos políticos eleitos para a Câmara de Vereadores de Cuiabá

\begin{tabular}{|c|c|c|c|c|c|}
\hline Candidato & Partido & Denominação & Título & Votação & Situação \\
\hline Toninho de Souza & PSD & Batista & Membro & 5.620 & Reeleito \\
\hline Misael Galvão & PR & Assembleia de Deus & Membro & 5.095 & Eleito \\
\hline Marcrean dos Santos & PRTB & Assembleia de Deus & Membro & 2.995 & Reeleito \\
\hline Abilio Jr - Abilinho & PSC & Assembleia de Deus & Membro & 2.623 & Eleito \\
\hline Renivaldo Nascimento & PSDB & Católico & Leigo & 4.789 & Reeleito \\
\hline Juca do Guaraná & PT do B & Católico & Leigo & 3.845 & Reeleito \\
\hline Felipe Wellaton & PV & Católico & Leigo & 3.054 & Eleito \\
\hline Marcelo Bussiki & PSB & Cristão & Membro & 3.583 & Eleito \\
\hline
\end{tabular}

Fonte: Quadro elaborado pelos autores.

Os dados estatísticos mostram que o centro-oeste possui uma presença evangélica acima da média nacional, 26\%. No entanto, nos legislativos municipais de suas três capitais o número de vereadores declaradamente evangélicos não impressiona, apresentando em Campo Grande uma pequena queda em comparaçáo com a legislatura anterior. Por outro lado, observando a votação dos demais candidatos evangélicos, percebe-se que ao menos outros três candidatos em cada capital apresentaram uma votação relativamente alta, alcançando a suplência, o que oferece a oportunidade de assumirem a vereança nos próximos quatro anos. Por outro lado, a

${ }^{25}$ Disponível em: <http://www.rdnews.com.br/curtinhas/serys-prb-e-igreja-universal/74678>. Acesso em: 27 dez. 2016.

${ }^{26}$ Em 2012 foram eleitos Marcrean dos Santos (PRTB) e Oséias Machado (PSC). No princípio de 2016, somaram-se a estes Marcos de Souza (PSC) e Pablo Queiroz (PSC).

Debates do NER, Porto Alegre, Ano i 8, N. 32, P. I 5-68, Jul./Dez. 20 I 7 
região é considerada um baluarte do conservadorismo, com grande atuação de segmentos católicos, o que dentro da lógica de uma hegemonia cristá poderia tornar desnecessária a autoafirmação. Enfim, sendo a presença evangélica bastante forte na regiâo, é possível que este segmento religioso tenha alcançado um grau de legitimidade semelhante ao do catolicismo, o que também tornaria a autoafirmação desnecessária. Por hora deixaremos essas hipóteses em aberto, uma vez que só poderiam ser confirmadas com uma pesquisa aprofundada na regiáo.

\section{REgião NoRdeste}

Segundo o Censo 2010, o nordeste brasileiro possui a segunda maior concentração de eleitores do país e a maior concentração de católicos, $72,2 \%$. Nas suas capitais este número diminui alguns pontos mantendo-se, mesmo assim, acima da média nacional na maioria dos casos. Por outro lado, também apresenta o segundo menor crescimento evangélico do país. Mesmo assim não se trata de um eleitorado que tenha sido desconsiderado. De fato, no período eleitoral notou-se uma movimentação em busca do apoio evangélico, principalmente através de representantes partidários e lideranças, sem, porém, ter havido grandes gestos dos partidos em relaçáo à populaçáo evangélica. Vejamos caso a caso.

Em Salvador/BA, Antônio Carlos Magalhães Neto (DEM - Democratas) reelegeu-se prefeito no primeiro turno com $73.9 \%$. Seu sucesso vem, em grande medida, de seu pertencimento a uma família com larga tradiçáo política na Bahia. Contou com o apoio de 14 partidos incluindo o PSC, PTC, PSDC e PRB. No entanto, marcou presença junto ao eleitorado evangélico, participando da Marcha Para Jesus, em 23 de julho, ${ }^{27}$ e negociando com o PRB seu apoio, uma vez que, inicialmente, o partido pretendia indicar

${ }^{27}$ Disponível em: <http://www.politicalivre.com.br/2016/07/marcha-para-jesus-40-millotam-ruas-de-salvador-em-manifestacao-de-fe/>. Acesso em: 27 dez. 2016. 
um vice para sua chapa. ${ }^{28}$ Porém, o vice foi indicado pelo PMDB. Mesmo com o enfraquecimento da esquerda partidária, a candidata do $\mathrm{PCdoB}$, Alice Portugal, chegou em segundo lugar, com 14,5\% votos. O deputado estadual Pastor Manoel Isidório (PDT), figura bastante popular em Salvador por coordenar tratamento de dependentes químicos na chamada Fundação Dr. Jesus, ficou em $3^{\circ}$ lugar, com 8,6\%. Em $4^{\circ}$ lugar chegou Cláudio Silva (PP) com o apoio do PR. Sua vice, Dinamene Meireles (PP), é membro da Assembleia de Deus.

Já para a Câmara de Vereadores de Salvador apresentaram-se 934 candidatos para as 43 cadeiras. Deles, ao menos 51 explicitaram o seu pertencimento religioso. Foram 43 evangélicos, 4 afrorreligiosos e 4 católicos. Foram eleitos 8 evangélicos, 2 a mais do que na legislatura anterior, 4 católicos e 2 afrorreligiosos.

Quadro 11 - Religiosos políticos eleitos para a Câmara de Vereadores de Salvador

\begin{tabular}{|c|c|c|c|c|c|}
\hline Candidato & Partido & Denominaçáo & Título & Votaçáo & Situaçáo \\
\hline Luiz Carlos & PRB & IURD & Pastor & 16.530 & Reeleito \\
\hline Isnard Araújo, & PHS & IURD & Pastor & 15.081 & Reeleito \\
\hline Rogéria Santos & PRB & IURD & Membro & 12.303 & Eleita \\
\hline Ireuda Silva & PRB & IURD & Membro & 11.888 & Eleita \\
\hline Palhinha & DEM & Adventista & Membro & 9.732 & Reeleito \\
\hline Cátia Rodrigues & PHS & Internacional da Graça & Membro & 9.597 & Reeleito \\
\hline Heber Santana & PSC & Assembleia de Deus & Membro & 8.874 & Reeleito \\
\hline Lorena Brandão & PSC & Batista & Membro & 7.312 & Eleita \\
\hline Paulo Câmara & PSDB & Católico & Leigo & 18.432 & Reeleito \\
\hline Alexandre Aleluia & DEM & Católico & Leigo & 8.941 & Eleito \\
\hline Joceval Rodrigues & PPS & Católico & Leigo & 7.833 & Eleito \\
\hline Henrique Carballal & PV & Católico & Leigo & 7.684 & Reeleito \\
\hline Suica & PT & Afrorreligioso & Membro & 9.797 & Reeleito \\
\hline Sílvio Humberto & PSB & Afrorreligioso & Membro & 6.260 & Reeleito \\
\hline
\end{tabular}

Fonte: Quadro elaborado pelos autores.

${ }^{28}$ Disponível em: <http://informebaiano.com.br/10180/destaques/prefeito-acm-netocomenta-pressao-do-prb-e-anuncio-do-vice>. Acesso em: 27 dez. 2016. 
Em Fortaleza/CE, Roberto Cláudio (PDT) reelegeu-se prefeito da cidade com o apoio de 17 partidos, entre eles o PSC, PSDC e PTC. O PR lançou a candidatura do Capitão Wagner Gomes, que ficou em 2o lugar. Já o PRB lançou a candidatura do deputado federal Ronaldo Martins (PRB), pastor da IURD. Chegou em 4o lugar. Apesar do número relativamente baixo de evangélicos na capital cearense (12\%), sua capacidade de mobilização fica evidente em eventos como a Marcha Para Jesus, a qual recebeu grande apoio do prefeito Roberto Cláudio. ${ }^{29}$

Para a Câmara de Vereadores de Fortaleza apresentaram-se 1.054 candidatos para as 43 vagas. Ao menos 26 candidatos explicitaram sua vinculação religiosa. Foram 21 evangélicos e 5 católicos. Elegeram-se 5 evangélicos e 4 católicos.

Quadro 12 - Religiosos políticos eleitos para a Câmara de Vereadores de Fortaleza

\begin{tabular}{|c|c|c|c|c|c|}
\hline Candidato & Partido & Denominaçáo & Título & Votaçáo & Situaçáo \\
\hline Antônio Henrique & PROS & Presbiteriana & Presbítero & 13.401 & Reeleito \\
\hline Elpídio Nogueira & PDT & Batista & Diácono & 10.394 & Reeleito \\
\hline Evaldo Costa & PRB & Evangélico & Membro & 8.586 & Eleito \\
\hline Mairton Felix & PDT & Assembleia de Deus & Membro & 8.323 & Reeleito \\
\hline Odécio Carneiro & SD & Assembleia de Deus & Membro & 7.877 & Eleito \\
\hline Célio Studart & SD & Católico & Leigo & 38.278 & Eleito \\
\hline Frota Cavalcante & PTN & Católico & Leigo & 6.228 & Reeleito \\
\hline Jorge Pinheiro & PSDC & Católico & Leigo & 5.969 & Eleito \\
\hline Michel Lins & PPS & Católico & Leigo & 5.275 & Eleito \\
\hline
\end{tabular}

Fonte: Quadro elaborado pelos autores.

Em Recife/PE a disputa para o executivo municipal ocorreu entre dois candidatos da esquerda, dividindo o voto religioso e gerando um grande número de votos nulos. Geraldo Júlio (PSB) recebeu o apoio de 20 partidos

${ }^{29}$ Disponível em: <http:/guiame.com.br/gospel/mundo-cristao/prefeito-de-fortaleza-declaraapoio-marcha-para-jesus-oportunidade-para-converter-vidas.html $>,<$ https://noticias. gospelmais.com.br/fortaleza-autoridades-entregam-chave-cidade-evangelicos-83023.html . Acesso em: 27 dez. 2016. 
incluindo a maior parte dos "cristãos". Foi reeleito no segundo turno. O candidato petista João Paulo ficou em segundo lugar, recebendo o apoio de 4 partidos, entre eles o PRB, que havia apoiado Geraldo Júlio em 2012. Para a Câmara de Vereadores de Recife apresentaram-se 916 candidatos para as 39 vagas. Cerca de 52 deles explicitaram a sua vinculação religiosa. Foram 49 evangélicos, 2 afrorreligiosos e 1 católico. Foram eleitos 10 evangélicos e 1 católico.

Quadro 13 - Religiosos políticos eleitos para a Câmara de Vereadores de Recife

\begin{tabular}{|c|c|c|c|c|c|}
\hline Candidato & Partido & Denominação & Título & Votaçáo & Situaçáo \\
\hline Michele Collins & PP & Assembleia de Deus & Missionária & 15.357 & Reeleita \\
\hline Aimée Carvalho & PSB & Assembleia de Deus & Irmã & 14.338 & Reeleita \\
\hline Fred Ferreira & PR & Assembleia de Deus & Membro & 14.277 & Eleito \\
\hline Davi Muniz & PEN & Adventista & Membro & 11.693 & Reeleito \\
\hline Natália de Menudo & PSB & Batista & Membro & 10.277 & Eleita \\
\hline Professora Ana Lúcia & PRB & IURD & Membro & 9.538 & Eleita \\
\hline Jadeval de Lima & PDT & Adventista & Membro & 8.831 & Reeleito \\
\hline Marcos Di Bria & PSDC & Casa da Benção & Membro & 7.355 & Reeleito \\
\hline Almir Fernando & PC do B & Rompendo em Fé & Membro & 6.852 & Reeleito \\
\hline Renato Antunes & PSC & Batista & Membro & 4.261 & Eleito \\
\hline Aerto Luna & PRP & Católico & Leigo & 5.216 & Reeleito \\
\hline
\end{tabular}

Fonte: Quadro elaborado pelos autores.

Em São Luís/MA, Enivaldo Holanda Júnior (PDT) foi eleito prefeito no segundo turno com 53,9\% dos votos. Embora o candidato não se declare abertamente evangélico, tal informação é divulgada em diversos meios. Chegou a receber um apoio formal da Assembleia de Deus, que convocou seus membros a votarem no "irmão". ${ }^{30}$ Também contou com o apoio do PRB, PSC, PTC e PR. A candidata Eliziane Gama (PPS), da Assembleia de Deus, ficou em $4^{\circ}$ lugar. Já seu vice, José Joaquim, possui estreitos laços com a Igreja Católica. E em 6o lugar ficou Rose Sales (PMB), membro da Assembleia de Deus.

${ }^{30}$ Disponível em: <https://www.marcoaureliodeca.com.br/2016/10/19/para-impedirderrota-edivaldo-apela-para-o-coronelismo-gospel/>. Acesso em: 27 dez. 2016. 
Para a Câmara de Vereadores de Sáo Luís apresentaram-se 610 candidatos para as 31 vagas. Vinte sete deles explicitaram a sua vinculação religiosa. Foram 21 evangélicos, 5 católicos e 1 afrorreligioso. Elegendo-se 4 evangélicos, os candidatos católicos e o candidato afrorreligioso.

Quadro 14 - Religiosos políticos eleitos para a Câmara de Vereadores de São Luís

\begin{tabular}{|c|c|c|c|c|c|}
\hline Candidato & Partido & Denominaçáo & Título & Votaçáo & Situaçáo \\
\hline Pavão Filho & PDT & Presbiteriana & Membro & 8.511 & Reeleito \\
\hline Marquinhos & DEM & Evangélico & Membro & 7.489 & Reeleito \\
\hline Ricardo Diniz & PC do B & Batista & Membro & 4.205 & Reeleito \\
\hline Edson Gaguinho & PHS & Evangélico & Membro & 4.028 & Reeleito \\
\hline Afonso Manoel & PMDB & Católico & Leigo & 8.057 & Eleito \\
\hline Ivaldo Rodrigues & PDT & Católico & Leigo & 5.115 & Reeleito \\
\hline Marcial Lima & PEN & Católico & Leigo & 5.007 & Reeleito \\
\hline Chaguinhas & PP & Católico & Leigo & 4.879 & Reeleito \\
\hline Bárbara Soeiro & PSC & Católico & Leigo & 4.420 & Reeleito \\
\hline Astro de Ogum & PR & Afrorreligioso & Pai & 8.766 & Reeleito \\
\hline
\end{tabular}

Fonte: Quadro elaborado pelos autores.

Assim como Roberto Cláudio, Firmino Filho (PSDB) foi reeleito prefeito de Teresina/PI com 51,14\% dos votos. Recebeu apoio dos segmentos evangélicos, tendo participado da Marcha Para Jesus. ${ }^{31}$ Também contou com o apoio do PSDC, PSC e PRB. Dr. Pessoa (PSD) chegou em $2^{\circ}$ lugar, tendo recebido o apoio do PR. Em $3^{\circ}$ lugar ficou Amadeus Campos (PTB), que obteve o apoio do PTC.

Para a Câmara de Vereadores de Teresina apresentaram-se 581 candidatos para as 29 vagas. Vinte e quatro deles explicitaram o seu pertencimento religioso. Foram 16 evangélicos, 7 católicos e 1 afrorreligioso. Foram eleitos 3 evangélicos e 5 católicos.

${ }^{31}$ Disponível em: <http://www.folhadeparnaiba.com.br/2013/05/teresina-marchapara-jesus-contou-com.html>. Acesso em: 8 dez. 2016. 
Quadro 15 - Religiosos políticos eleitos para a Câmara de Vereadores de Teresina

\begin{tabular}{|c|c|c|c|c|c|}
\hline Candidato & Partido & Denominaçáo & Título & Votaçáa & Situaçáo \\
\hline Levino de Jesus & PRB & IURD & Pastor & 6.288 & Reeleito \\
\hline Ricardo Bandeira & PSDC & Evangélico & Pastor & 4.315 & Reeleito \\
\hline Lázaro Carvalho & PPS & Evangélico & Membro & 2.626 & Eleito \\
\hline Aluísio Sampaio & PP & Católico & Leigo & 5.186 & Reeleito \\
\hline Teresa Britto & PV & Católica & Leiga & 4.926 & Reeleita \\
\hline Valdemir Virgino & PRP & Católico & Leigo & 4.360 & Reeleito \\
\hline Dudu & PT & Católico & Leigo & 4.123 & Reeleito \\
\hline Cida Santiago & PHS & Católica & Leiga & 3.357 & Reeleita \\
\hline
\end{tabular}

Fonte: Quadro elaborado pelos autores.

Em Aracaju/SE a disputa se concentrou em dois candidatos da esquerda, Edvaldo Nogueira (PC do B), eleito no segundo turno, em uma coligação de 7 partidos, incluindo o PRB, e Valadares Filho (PSB), que ficou em 2o lugar, recebendo o apoio de 13 partidos, incluindo o PSC, PR, PTC e PSDC. Seu vice foi o Presidente da Assembleia de Deus Sergipe, o pastor Antônio dos Santos (PSC). Edvaldo manteve uma boa relação com o meio evangélico em sua gestão anterior $(2008$ - 2012) apoiando a realização de eventos como o já tradicional show gospel durante o aniversário da cidade, e a Marcha Para Jesus ${ }^{32}$. Apresentou-se como "cristáo".

Para a Câmara de Vereadores de Aracaju compareceram 402 candidatos para as 24 vagas. Deles, ao menos 22 explicitaram a sua vinculação religiosa. Foram 18 evangélicos, 3 católicos e 1 espírita. Elegeram-se apenas 2 evangélicos, ao contrário de 2012 quando foram eleitos 5. Também foram eleitos 1 católico e o candidato espírita.

32 Disponível em: <http://www.brasil247.com/pt/247/sergipe247/245599/A-convitede-Heleno-Edvaldo-prestigia-evento-gospel.htm $>$, <http://www.institutomarcelodeda. com.br/pastores-evangelicos-visitam-gabinete-do-prefeito-edvaldo-nogueira/>, $<$ http://universopolitico.com.br/em-evento-com-evangelicos-edvaldo-e-eliane-secomprometem-com-pauta-social/>. Acesso em: 27 dez. 2016.

Debates do NER, Porto Alegre, ano i 8, N. 32, P. I 5-68, Jul./Dez. 2017 
Quadro 16 - Religiosos políticos eleitos para a Câmara de Vereadores de Aracaju

\begin{tabular}{|c|c|c|c|c|c|}
\hline Candidato & Partido & Denominaçáo & Título & Votaçáo & Situaçáo \\
\hline Carlito Alves & PRB & IURD & Pastor & 3.996 & Eleito \\
\hline Emília Corrêa & PEN & Assembleia de Deus & Membro & 3.652 & Reeleita \\
\hline Vinicius Porto & DEM & Católico & Leigo & 7.802 & Reeleito \\
\hline Elber Batalha & PSB & Espírita & Membro & 3.252 & Eleito \\
\hline
\end{tabular}

Fonte: Quadro elaborado pelos autores.

Em Maceió/AL, Rui Palmeira (PSDB) foi reeleito prefeito no segundo turno contando com o apoio de 5 partidos entre eles o PR. O candidato desenvolveu um bom relacionamento com lideranças evangélicas locais chegando a participar de eventos da Assembleia de Deus. ${ }^{33}$ Em 2o lugar chegou Cícero Almeida (PMDB), embora tenha tido apoio de uma grande coligação de 11 partidos incluindo o PSC e o PRB. Em 3o lugar ficou João Henrique Caldas (PSB), membro da Igreja Internacional da Graça de Deus.

Para a Câmara de Vereadores de Maceió apresentaram-se 209 candidatos para as 21 vagas. Ao menos 17 candidatos explicitaram a sua vinculação religiosa. Foram 9 evangélicos, 6 católicos e 2 afrorreligiosos. Foram eleitos todos os católicos e uma candidata evangélica, ao contrário de 2012 quando foram eleitos 3 evangélicos. ${ }^{34}$

33 Disponível em: <http://www.tribunadosertao.com.br/2015/10/maceio-prefeito-ruipalmeira-participou-forum-das-igrejas-evangelicas/>. Acesso em: 14 nov. 2016.

${ }^{34}$ Em 2012, foram eleitos Heloísa Helena (PSOL), Marcelo Gouveia (PRB) e João Luís (DEM), da AD, IURD e Quadrangular respectivamente. Posteriormente, assumiu a suplência o Pastor Luiz Carlos (DEM), da Igreja Quadrangular. 
Quadro 17 - Religiosos políticos eleitos para a Câmara de Vereadores de Maceió

\begin{tabular}{|c|c|c|c|c|c|}
\hline Candidato & Partido & Denominaçáo & Título & Votaçáo & Situaçáo \\
\hline Dudu Ronalsa & PSDB & Católico & Leigo & 11.623 & Reeleito \\
\hline Chico Holanda Filho & PP & Católico & Leigo & 10.845 & Reeleito \\
\hline Eduardo Canuto & PSDB & Católico & Leigo & 8.651 & Reeleito \\
\hline Fátima Santiago & PP & Católica & Leiga & 7.459 & Reeleita \\
\hline Silvio Camelo & PV & Católico & Leigo & 6.951 & Reeleito \\
\hline Samyr Malta & PSDC & Católico & Leigo & 4.690 & Reeleito \\
\hline Siderlane Mendonça & PEN & Evangélico & Membro & 4.119 & Eleito \\
\hline
\end{tabular}

Fonte: Quadro elaborado pelos autores.

Em João Pessoa/PB houve uma forte divisão do voto evangélico. Luciano Cartaxo (PSD) reelegeu-se prefeito com 59,6\%, tendo contado com o apoio do PSC, PRB e PSDC. Também recebeu apoio direto de alguns segmentos evangélicos, principalmente entre as Assembleias de Deus. ${ }^{35}$ Em $2^{\circ}$ lugar ficou a professora Cida Ramos (PSB), coligada com 16 partidos, entre eles o PTC e o PR, tendo recebido amplo apoio de pequenas denominaçóes evangélicas. ${ }^{36}$

Para a Câmara de Vereadores de João Pessoa apresentaram-se 496 candidatos para as 27 vagas. Destes, ao menos 25 explicitaram o seu pertencimento religioso. Foram 18 evangélicos e 7 católicos. Foram eleitos 6 evangélicos, um a menos do que em 2012, e 5 católicos.

${ }^{35}$ Disponível em: <http://www.parlamentopb.com.br/Noticias/?luciano-cartaxo-recebeapoio-de-evangelicos-da-assembleia-de-deus-06.08.2016>. Acesso em: 14 nov. 2016.

${ }^{36}$ Disponível em: <http://www.politicaetc.com.br/2016/06/cida-ramos-temreuniao-com-pastores-evangelicos/>, <http://www.wscom.com.br/noticias/politica/ cida+ramos+recebe+apoio+de+mais + de $+150+$ liderancas + religiosas-200273 > . Acesso em: 14 nov. 2016.

Debates do NER, Porto Alegre, ano i 8, N. 32, P. I 5-68, Jul./Dez. 20 I 7 
Quadro 18 - Religiosos políticos eleitos para a Câmara de Vereadores de João Pessoa

\begin{tabular}{|c|c|c|c|c|c|}
\hline Candidato & Partido & Denominaçáo & Título & Votaçáo & Situaçáo \\
\hline Durval Ferreira & PP & Assembleia de Deus & Membro & 7.000 & Reeleito \\
\hline Tanilson Soares & PEN & Presbiteriana & Membro & 6.611 & Eleito \\
\hline Eliza Vírginia & PSDB & Assembleia de Deus & Membro & 6.036 & Reeleita \\
\hline Lucas de Brito & PSL & Batista & Membro & 5.301 & Reeleito \\
\hline José Luiz Pereira & PRB & IURD & Bispo & 4.985 & Eleito \\
\hline Helton Renê & PC do B & Assembleia de Deus & Membro & 4.102 & Reeleito \\
\hline Marcus Vinícius & PSDB & Católico & Leigo & 5.052 & Reeleito \\
\hline Raíssa Lacerda & PSD & Católico & Leiga & 4.382 & Reeleita \\
\hline Bruno Farias & PPS & Católico & Leigo & 4.095 & Reeleito \\
\hline João Corujinha & PSDC & Católico & Leigo & 3.997 & Reeleito \\
\hline Thiago Lucena & PMN & Católico & Leigo & 3.553 & Eleito \\
\hline
\end{tabular}

Fonte: Quadro elaborado pelos autores.

Em Natal/RN, Carlos Eduardo (PDT) reelegeu-se prefeito da cidade no primeiro turno com $63,42 \%$ dos votos, contando com o apoio do PR, PROS, PRB, PSDC e principalmente do PSC, que possui grande capacidade de mobilização na capital. ${ }^{37} \mathrm{O}$ prefeito manteve uma boa relação com o eleitorado evangélico, chegando a realizar um culto de Ação de Graças na prefeitura durante a sua gestão. ${ }^{38}$ Kelps de Oliveira (SD) chegou em 2o lugar tendo recebido o apoio do PTC.

Para a Câmara de Vereadores de Natal apresentaram-se 549 candidatos para as 29 vagas. Ao menos 29 explicitaram a sua vinculação religiosa. Foram 16 evangélicos, 12 católicos e 1 afrorreligioso. Foram eleitos 3 evangélicos e 8 católicos.

${ }^{37}$ Disponível em: <http://blog.tribunadonorte.com.br/heitorgregorio/psc-deadenubio-melo-vai-apoiar-carlos-eduardo/>. Acesso em: 27 dez. 2016.

38 Disponível em: <http://agorarn.com.br/politicaantiga/carlos-eduardo-promove-cultoevangelico-dentro-do-palacio-felipe-camarao/>. Acesso em: 27 dez. 2016. 
Quadro 19 - Políticos religiosos eleitos para a Câmara de Vereadores de Natal

\begin{tabular}{|c|c|c|c|c|c|}
\hline Candidato & Partido & Denominaçáo & Título & Votaçáo & Situaçáo \\
\hline Carla Dickson & PROS & Assembleia de Deus & Membro & 7.924 & Eleita \\
\hline Francisco de Assis & PRB & IURD & Bispo & 5.160 & Reeleito \\
\hline Eriko Jacomé & PTN & Assembleia de Deus & Membro & 2.577 & Eleito \\
\hline Raniere Barbosa & PDT & Católico & Leigo & 10.510 & Reeleito \\
\hline Júlia Arruda & PDT & Católica & Leiga & 5.765 & Reeleita \\
\hline Ana Paula & PSDC & Católica & Leiga & 5.465 & Eleita \\
\hline Kleber Fernandes & PDT & Católico & Leigo & 5.061 & Eleito \\
\hline Eudiane Macedo & SD & Católica & Leiga & 4.922 & Eleita \\
\hline Wilma de Faria & PT do B & Católica & Leiga & 4.421 & Reeleita \\
\hline Franklin Capistrano & PSB & Católico & Leigo & 4.003 & Reeleito \\
\hline Sueldo Medeiros & PHS & Católico & Leigo & 1.829 & Eleito \\
\hline
\end{tabular}

Fonte: Quadro elaborado pelos autores.

Como se pode ver nos quadros acima, na região Nordeste é significativo o número de vereadores eleitos que acionaram o seu pertencimento ao catolicismo. Estão, desta forma, valorizando um importante componente religioso e cultural da região, sabendo que ele possui a sua importância na atração de votos. Porém, os evangélicos também se fizeram presente nas composiçôes dos legislativos municipais. Em Recife, foram eleitos 10 evangélicos e 1 católico, invertendo uma tendência. Aliás, Salvador também figura nesta direção, pois ali foram eleitos 8 evangélicos e 4 católicos. $\mathrm{Na}$ capital baiana, ainda, foram eleitos 2 afrorreligiosos o mesmo ocorrendo em São Luís, com a eleição de um afrorreligioso. Em ambas as cidades, como se sabe, o campo afrorreligioso, através do Candomblé e do Tambor de Mina, possui uma presença histórica, tendo se afirmado como patrimônio imaterial.

\section{Regiâo Norte}

A região norte apresenta a maior porcentagem de evangélicos do país e a menor porcentagem de católicos. Como podemos observar a seguir, a presença evangélica no processo eleitoral é grande e, assim como ocorreu no nordeste, a presença dos partidos cristãos entre os primeiros lugares indica a 
importância do apoio destes segmentos. Porém, diferentemente da prudência observada no nordeste, houve, na regiáo norte, uma forte tendência dos candidatos a se comprometerem com o meio evangélico.

Em Manaus/AM, Arthur Neto (PSDB) reelegeu-se como prefeito no segundo turno, tendo contado com o apoio de 10 partidos. Dividiu o apoio evangélico com o deputado federal Silas Câmara (PRB), pastor da Assembleia de Deus, que ficou em $3^{\circ}$ lugar e que contou com o apoio do PSC. Neto recebeu o apoio do Apóstolo Rêne Terra Nova, do Ministério Internacional Restauração (MIR), denominação que detém grande presença na capital amazonense. $\mathrm{O}$ apóstolo congregou lideranças e promoveu eventos de apoio ao candidato ${ }^{39}$. Marcelo Ramos (PR) ficou em $2^{\circ}$ lugar e obteve o apoio do PTC. Recebeu o apoio de Silas Câmara no segundo turno, embora seu passado de filiaçáo ao $\mathrm{PC}$ do $\mathrm{B}$ tenha pesado contra esta aliança. $\mathrm{O}$ candidato petista José Ricardo Wendling, que possui ligaçôes com a Igreja Católica, ficou em $5^{\circ}$ lugar. Também é digno de nota a candidatura do deputado federal Hissa Abrahão (PDT), da Aliança Evangélica, que chegou em $6^{\circ}$ lugar, e contou com o apoio do PSDC.

Para a Câmara de Vereadores de Manaus apresentaram-se 1.276 candidatos para as 41 vagas. Ao menos 54 deles explicitaram a sua vinculação religiosa. Foram 45 evangélicos, 7 católicos, 1 afrorreligioso e 1 que se declarou cristão. Foram eleitos 14 evangélicos, ou seja, um terço dos vereadores e 6 católicos e o candidato cristáo, conforme mostra o quadro que segue.

${ }^{39}$ Disponível em: <http://portalbare.net/2016/10/rene-terra-nova-lidera-ala-evangelicaa-favor-de-artur/>. Acesso em: 20 nov. 2016. 
Quadro 20 - Religiosos políticos eleitos para a Câmara de Vereadores de Manaus

\begin{tabular}{|c|c|c|c|c|c|}
\hline Candidato & Partido & Denominaçáo & Título & Votaçáo & Situaçáo \\
\hline João Luiz & PRB & IURD & Pastor & 13.978 & Eleito \\
\hline Reizo Castelo Branco & PTB & Madureira & Membro & 10.403 & Reeleito \\
\hline Marcel Alexandre & PMDB & MIR & Apóstolo & 9.566 & Reeleito \\
\hline Felipe Souza & PTN & Batista & Membro & 9.263 & Reeleito \\
\hline Gilmar Nacimento & PDT & Batista & Membro & 8.734 & Reeleito \\
\hline Roberto Sabino & PROS & Assembleia de Deus & Membro & 8.728 & Reeleito \\
\hline Roberto Sabino & PROS & Assembleia de Deus & Membro & 8.728 & Reeleito \\
\hline Jaildo de Oliveira & PCdoB & Evangélico & Membro & 8.011 & Eleito \\
\hline Joelson Silva & PSC & Assembleia de Deus & Pastor & 7.959 & Reeleito \\
\hline Wallace Oliveira & PTN & $\begin{array}{c}\text { Igreja de Deus } \\
\text { Pentecostal }\end{array}$ & Membro & 6.819 & Eleito \\
\hline Samuel da Costa & PHS & Adventista & Membro & 5.801 & Reeleito \\
\hline Chico Preto & PMN & Batista & Membro & 5.079 & Eleito \\
\hline Fred Mota & PR & $\begin{array}{c}\text { Igreja Internacional } \\
\text { da Graça }\end{array}$ & Membro & 4.881 & Eleito \\
\hline André Luiz Siqueira & PTC & $\begin{array}{c}\text { Mundial do Poder } \\
\text { de Deus }\end{array}$ & Missionário & 3.277 & Eleito \\
\hline Wilker Barreto & PHS & Católico & Leigo & 10.206 & Reeleito \\
\hline Álvaro Campelo & PP & Católico & Leigo & 9.573 & Reeleito \\
\hline Therezinha Ruiz & DEM & Católica & Leiga & 7.571 & Reeleita \\
\hline Elias Emanuel & PSDB & Católico & Leigo & 6.397 & Reeleito \\
\hline Marcelo Serafim & PSB & Católico & Leigo & 5.108 & Eleito \\
\hline Glória Carratte & PRP & Católica & Leiga & 5.059 & Reeleita \\
\hline William Abreu & PMN & Cristão & Membro & 3.820 & Eleito \\
\hline
\end{tabular}

Fonte: Quadro elaborado pelos autores.

Em Belém/PA, Zenaldo Coutinho (PSDB) reelegeu-se prefeito com o apoio de 15 partidos incluindo PSC, PR, PTC e PSDC. O prefeito de Belém mantém uma boa relaçáo com o meio evangélico, tendo participado de eventos promovidos por este segmento religioso durante todo seu mandato. ${ }^{40} \mathrm{Em} 2{ }^{\circ}$ lugar ficou Edimilson Rodrigues (PSOL), que recebeu

${ }^{40}$ Disponível em: <http://ww3.belem.pa.gov.br/www/em-pauta/igrejas-evangelicas-realizamculto-dedicado-aniversario-belem/>, <http://ww3.belem.pa.gov.br/www/em-pauta/ zenaldo-e-homenageado-por-obreiros-da-igreja-evangelica/>. Acesso em: 20 nov. 2016.

Debates do NER, Porto Alegre, ano i 8, N. 32, P. I 5-68, JUl./Dez. 2017 
algum apoio evangélico, principalmente das Assembleias de Deus ${ }^{41}$. O ex-reitor da UFPA, Carlos Maneschy (PMDB), chegou em $5^{\circ}$ lugar e contou com o apoio do PRB.

Para a Câmara de Vereadores de Belém apresentaram-se 815 candidatos para as 35 vagas. Destes, cerca de 34 explicitaram o seu pertencimento religioso. Foram 29 evangélicos, 3 católicos e 1 afrorreligioso e 1 candidato cristão. Foram eleitos 6 evangélicos, os 3 católicos e o candidato cristão.

Quadro 21 - Religiosos políticos eleitos para a Câmara de Vereadores de Belém

\begin{tabular}{|c|c|c|c|c|c|}
\hline Candidato & Partido & Denominaçáo & Título & Votaçáo & Situaçáo \\
\hline Simone Kahwage & PRB & IURD & Cantora & 9.575 & Eleita \\
\hline Ivanildo França & PRB & IURD & Membro & 8.801 & Eleito \\
\hline Paulo Bengtson & PTB & Quadrangular & Membro & 6.646 & Reeleito \\
\hline Moa Moraes & PC do B & Assembleia de Deus & Membro & 6.401 & Eleito \\
\hline Nemias Valentim & PSDB & Adventista & Membro & 5.934 & Reeleito \\
\hline José Dinely & PSC & Assembleia de Deus & Membro & 5.880 & Reeleito \\
\hline Mauro Freitas & PSDC & Católico & Leigo & 6.899 & Reeleito \\
\hline Toré Lima & PRB & Católico & Membro & 4.077 & Eleito \\
\hline Celsinho Sabino & PSC & Católico & Leigo & 4.398 & Eleito \\
\hline Sargento Silvano & PSD & Cristão & Membro & 3.903 & Eleito \\
\hline
\end{tabular}

Fonte: Quadro elaborado pelos autores.

Em Palmas/TO, Carlos Henrique Amastha (PSB) elegeu-se com 52.3\% com o apoio do PTC e de várias denominaçóes evangélicas como a Casa da Benção e a Igreja de Cristo, além da Coimadetins (Convenção de Igrejas e Ministros das Assembleias de Deus Missão no Tocantins). ${ }^{42}$ Raúl Filho

${ }^{41}$ Disponível em: <http://ed50.com.br/2016/10/15/liderancas-evangelicas-estao-comedmilson/>. Acesso em: 20 nov. 2016.

42 Disponível em: <http://www.t1 noticias.com.br/eleicoes2016/em-reuniao-com-amasthaevangelicos-reforcam-apoio-a-reeleicao-do-prefeito/79128/>,<http://www.gospelgeral. com.br/index.php/2016/10/02/evangelicos-ajudam-eleger-prefeito-carlos-amastha/>. Acesso em: 27 dez. 2016. 
(PR), tendo como vice o Pastor João Campos (PSC), da Assembleia de Deus, ficou em $2^{\circ}$ lugar. Cláudia Lelis (PV) chegou em $3^{\circ}$ lugar com o apoio do PRB e PSDC.

Para a Câmara de Vereadores de Palmas apresentaram-se 295 candidatos para as 19 vagas. Ao menos 26 explicitaram o seu pertencimento religioso. Foram 23 evangélicos, dos quais elegeram-se 7 e 3 católicos, 2 deles tendo sido eleitos.

Quadro 22 - Religiosos políticos eleitos para a Câmara de Vereadores de Palmas

\begin{tabular}{|c|c|c|c|c|c|}
\hline Candidato & Partido & Denominaçáo & Título & Votaçáo & Situaçáo \\
\hline Leo Barbosa & SD & Evangélico & Membro & 2.678 & Eleito \\
\hline Tiago Andrino & PSB & Evangélico & Membro & 2.499 & Eleito \\
\hline Rogério Freitas & PMDB & Igreja de Cristo & Membro & 2.253 & Reeleito \\
\hline Marilon Barbosa & PSB & Assembleia de Deus & Membro & 1.978 & Eleito \\
\hline Filipe Martins & PSC & Madureira & Membro & 1.831 & Eleito \\
\hline Diogo Fernandes & PSD & Batista & Membro & 1.636 & Eleito \\
\hline Milton Neris & PP & Minova & Membro & 1.537 & Reeleito \\
\hline Laudecy Coimbra & SD & Católica & Leiga & 1.784 & Eleita \\
\hline Major Negreiros & PSB & Católico & Leigo & 1.702 & Reeleito \\
\hline
\end{tabular}

Fonte: Quadro elaborado pelos autores.

Em Macapá/AP, Clécio Luís (REDE) obteve o apoio evangélico e foi reeleito como prefeito no segundo turno com $60,5 \%$ dos votos. Contou com o apoio de 7 partidos, entre eles o PSC. Em 2o lugar ficou o sociólogo e senador Gilvam Borges (PMDB), figura que não agrada o eleitorado cristão principalmente por propor a regulamentação da eutanásia no Brasil. Aline Gurgel (PRB), evangélica, ficou em 30 lugar, tendo alcançado 26,37\% dos votos. Contou com o apoio de 8 partidos incluindo o PR e o PSDC e dividindo o apoio evangélico com Clésio Luís. O PEN por sua vez, lançou a candidatura de Moisés Rivaldo, que ficou em $4^{\circ}$ lugar e obteve o apoio do PTC.

Para a Câmara de Vereadores de Macapá apresentaram-se 302 candidatos para as 23 vagas. Apenas 7 explicitaram sua vinculação religiosa, foram 6 evangélicos e um católico, elegendo-se 3 evangélicos e o candidato católico. 
Quadro 23 - Religiosos políticos eleitos para a Câmara de Vereadores de Macapá

\begin{tabular}{|c|c|c|c|c|c|}
\hline Candidato & Partido & Denominaçáo & Título & Votaçáo & Situaçáo \\
\hline Aristides Lopes & PRP & Evangélico & Pastor & 3.813 & Eleito \\
\hline Patriciana Guimarães & PRB & IURD & Membro & 3.767 & Eleita \\
\hline Odilson Nunes & PRB & Evangélico & Membro & 3.530 & Eleito \\
\hline Professor Rodrigo & Rede & Católico & Leigo & 2.090 & Eleito \\
\hline
\end{tabular}

Fonte: Quadro elaborado pelos autores.

Em Porto Velho/RO, Dr. Hilton de Lima (PSDB) foi eleito prefeito da cidade com $65.15 \%$ dos votos. Obteve o apoio do PSDC. Léo Moraes (PTB), que chegou em 2o lugar, teve o apoio do PSC. Dr. Mauro (PSB) ficou em 3o lugar e o PTC lhe deu apoio. Já Severino dos Ramos (DEM), pastor da Assembleia de Deus, concorreu como vice de Williames Pimentel (PMDB) ficando em 4o lugar e o Pastor James Melo (PR), da Igreja Cristo Verdade que Liberta, concorreu como vice de Dr. Ribamar Araújo (PR), ficando em $5^{\circ}$ lugar.

Para a Câmara de Vereadores de Porto Velho apresentaram-se 397 candidatos para as 21 vagas. Deles, ao menos 18 explicitaram sua vinculação religiosa. Foram 15 evangélicos, 2 afrorreligiosos e 1 católico. Foram eleitos 5 evangélicos e o candidato católico, como mostra o quadro abaixo.

Quadro 24 - Políticos religiosos eleitos para a Câmara de Vereadores de Porto Velho

\begin{tabular}{|c|c|c|c|c|c|}
\hline Candidato & Partido & Denominaçáo & Título & Votaçáo & Situaçáo \\
\hline Edésio Fernandes & PRB & IURD & Pastor & 3.738 & Eleito \\
\hline Joelna Holder & PMDB & Assembleia de Deus & Membro & 3.666 & Eleita \\
\hline Marcelo Cruz & PTB & Assembleia de Deus & Membro & 2.990 & Eleito \\
\hline Cristiane Lopes & PP & MIR & Membro & 2.887 & Eleita \\
\hline Da Silva do Sinttrar & PSB & Evangélico & Membro & 2.218 & Eleito \\
\hline Zequinha Araújo & PMDB & Católico & Leigo & 3.175 & Eleito \\
\hline
\end{tabular}

Fonte: Quadro elaborado pelos autores.

Já em Boa Vista/RR, Maria Teresa Saenz (PMDB) reelegeu-se prefeita com 79,39\%, com apoio da Omer (Ordem dos Ministros Evangélicos de Roraima), além do PR e do PSDC. Em 2o lugar ficou Sandro Baré (PP) 
cujo vice, Frankembergen Galvão (PSC), é pastor da Assembleia de Deus. Receberam o apoio do PTC, PRB e PSC. Maria Tereza, eleita para seu $5^{\circ}$ mandato como prefeita de Boa Vista, mantêm uma boa relação com os segmentos evangélicos, apoiando a realização da Marcha Para Jesus na capital. ${ }^{43}$

Para a Câmara de Vereadores de Boa Vista apresentaram-se 330 candidatos para as 21 vagas. Doze deles explicitaram a sua vinculação religiosa, destes, 9 eram evangélicos, elegendo-se 3, também foram eleitos 1 católico e 2 que se declararam cristãos.

Quadro 25 - Religiosos políticos eleitos para a Câmara de Vereadores de Boa Vista

\begin{tabular}{|c|c|c|c|c|c|}
\hline Candidato & Partido & Denominaçáo & Título & Votação & Situaçáo \\
\hline Manoel Neves & PRB & IURD & Pastor & 2.333 & Reeleito \\
\hline Mirian Reis & PHS & Assembleia de Deus & Membro & 2.045 & Reeleita \\
\hline Eduardo Jorge Rocha & PSC & Quadrangular & Pastor & 1.327 & Eleito \\
\hline Wagner Feitosa & SD & Cristão & Membro & 2.334 & Eleito \\
\hline Zélio Mota & PSD & Cristão & Membro & 1.415 & Eleito \\
\hline Vavá do Thianguá & PSD & Católico & Membro & 1.679 & Eleito \\
\hline
\end{tabular}

Fonte: Quadro elaborado pelos autores.

Em Rio Branco/AC foi eleito o único prefeito pelo PT. Marcus Alexandre reelegeu-se com 54,8\% dos votos e obteve o apoio de 14 partidos incluindo o PRB e PSDC. A peculiaridade é que logo após a sua eleição em 2012, Marcus Alexandre passou a congregar na Igreja Batista do Bosque (IBB), uma das maiores denominaçóes do Acre, que também o apoiou durante o pleito $^{44}$. Em $4^{\mathrm{o}}$ lugar ficou Raimundo Vaz (PR) que contou com o apoio de 5 partidos, incluindo o PTC, PSC e PEN.

${ }^{43}$ Disponível em: <http://www.portaluniversogospel.com.br/prefeitura-de-boa-vista-eomer-lancam-marcha-para-jesus-2015/>. Acesso em: $27 \mathrm{dez} .2016$.

${ }^{44}$ Disponível em: <http://www.ac24horas.com/2012/12/12/marcus-alexandre-pt-realiza-sonho-dos-crentes-e-vira-o-primeiro-prefeito-evangelico-da-historia-de-rio-branco/>. Acesso em: 27 dez. 2016. 
Para a Câmara de Vereadores de Rio Branco apresentaram-se 284 candidatos para as 17 vagas. Pelo menos 19 explicitaram a sua vinculaçáo religiosa, destes 18 eram evangélicos. Foram eleitos 4 evangélicos e 1 católico.

Quadro 26 - Políticos religiosos eleitos para a Câmara de Vereadores de Rio Branco

\begin{tabular}{|c|c|c|c|c|c|}
\hline Candidato & Partido & Denominaçáo & Título & Votaçáo & Situaçáo \\
\hline Elzinha Mendonça & PDT & Batista & Membro & 3.878 & Eleita \\
\hline Manuel Marcos & PRB & IURD & Pastor & 2.863 & Reeleito \\
\hline Raimundo Neném & PHS & Assembleia de Deus & Membro & 2.462 & Eleito \\
\hline Artêmio Costa & PSB & Evangélico & Membro & 2.131 & Reeleito \\
\hline Jackson Ramos & PT & Católico & Leigo & 3.615 & Eleito \\
\hline
\end{tabular}

Fonte: Quadro elaborado pelos autores.

Os quadros acima mostram que a regiáo mais evangélica do Brasil foi também aquela onde, proporcionalmente, mais se destacaram não somente os pertencimentos evangélicos dos candidatos como também a eleiçáo deles. Este fato reforça a força política que a população evangélica detêm no Brasil com diferenças, porém, segundo as regiôes e metrópoles, como estamos mostrando neste texto.

\section{CONSIDERAÇÓES FINAIS}

Como se pode notar neste sobrevoo das ocorrências relativas à relaçáo entre religióes e política nas eleiçóes municipais de 2016, em todas as capitais estaduais a presença de partidos religiosos e de candidatos religiosos se fez presente. Evidentemente, eles tiveram um peso diferenciado segundo as metrópoles e as regiōes brasileiras. Os partidos políticos que possuem alguma vinculaçáo religiosa a realizam no contexto cristáo. Por isso mesmo, carregam esta palavra na nominata partidária. Evidentemente que um estudo mais aprofundado poderia evidenciar até que ponto a especificidade cristâ na denominação partidária é portadora de especificidades programáticas e práticas dos líderes, políticos e membros dos partidos que carregam o apelo religioso. Igualmente, em todas as regióes brasileiras a maior incidência de candidatos 
que explicitaram o seu pertencimento religioso provem do campo cristáo, com destaque para o evangélico e talvez em menor importância o católico.

A representatividade evangélica provém tanto de denominaçōes históricas, como as Batistas, quanto de pentecostais tradicionais, como as Assembleias de Deus, e de igrejas neopentecostais, com destaque para a IURD. A propósito desta última igreja, um estudo interessante a ser realizado poderia recair sobre a sua representatividade nacional, tanto em termos de proposituras de candidatos quanto de eleitos e de suas práticas políticas, seja nos parlamentos municipais, estaduais e no Congresso Nacional. Seja como for, tornou-se lugar-comum falar-se de que os evangélicos eleitos para as assembleias legislativas formam as chamadas "bancadas evangélicas". Ressalve-se, porém, que por diversas razóes, que não cabe aqui explorar, em muitos casos tais bancadas náo chegam a constituir-se ou constituem-se parcialmente. Quando isto ocorre parece que os evangélicos assim procedem por espelharem-se nas estratégias de seus correligionários nas assembleias legislativas, e especialmente no Congresso Nacional, onde se tornou mais comum a oficialização de bancadas ou frentes de interesses.

Em termos gerais os dados indicam um crescimento nas últimas eleiçôes municipais das candidaturas religiosas em relaçáo a eleiçóes anteriores, cujas motivaçôes e/ou estratégias, porém, ainda não estão bem claras. No entanto, percebe-se nos discursos dos candidatos uma grande preocupaçáo com a crise política e moral que se instaurou nos últimos anos, principalmente no âmbito federal. Desta forma, além de bandeiras comuns à maioria das candidaturas, como saúde, educação e segurança, os candidatos evangélicos e católicos acionam discursos com ênfase na "defesa da família", "da moral" e de luta "contra a corrupçáo". Os candidatos afrorreligiosos, por sua vez, acionam discursos de "luta contra a intolerância religiosa", contra o "racismo", e em defesa dos "direitos das minorias".

Embora o objetivo deste texto não tenha sido o de avançar muito mais do que os dados apresentados, é relevante chamar a atenção para alguns fatos acerca dos prefeitos eleitos. Primeiramente, a maioria deles teve apoio dos aqui chamados partidos cristãos. Segundo, a maioria dos eleitos, e sobretudo 
dos reeleitos, manteve uma boa relação com os segmentos evangélicos locais, apoiando as suas manifestaçóes em espaços públicos, principalmente as chamadas Marchas para Jesus, chegando inclusive a participarem delas alguns candidatos a prefeitos. E terceiro, a questão ideológica dos candidatos a prefeitos, que poderia situá-los como sendo de direita ou de esquerda, em razão os seus vínculos ou alianças partidários, não se constituiu numa variável determinante para obter maior ou menor apoio dos segmentos evangélicos.

Para o legislativo, podemos observar que os evangélicos estão presentes nas Câmaras Municipais de todas capitais, sendo que a maioria destes religiosos políticos estão ligados a Assembleia de Deus, com 44 membros (32\%), seguido da IURD com 31 membros (22\%) e dos Batistas com 19 membros (13\%). Deve-se considerar que o destaque assumido pela IURD radica em sua eficiência em utilizar toda sua capacidade eleitoral através da candidatura oficial e do convencimento dos seus fieis em votarem nos candidatos propostos pelas cúpulas dirigentes das igrejas locais. ${ }^{45}$. As demais denominações, juntamente com aqueles que assumem a identidade religiosa genérica de "cristãos" ou "evangélicos" somam 43 membros (31\%). Como já mencionado anteriormente, podemos observar que a capacidade eleitoral do segmento evangélico está diretamente associado a sua presença proporcional em cada região, mas também está sujeita a especificidades locais.

O quadro abaixo explicita a correlação entre a presença evangélica nos legislativos municipais das capitais brasileiras nos anos de 2012 e 2016, assim como os dados do Censo 2010 sobre o pluralismo religioso existente, então, em cada uma delas.

45 Tal observação é valida apenas para as capitais, uma vez que não há um levantamento dos membros da IURD nas Câmaras Municipais dos demais municípios brasileiros. No entanto, se considerarmos a sua eficiência eleitoral é possível que este número supere o de outras denominaçóes. 
Quadro 27 - Vereadores evangélicos em 2012 e 2016 e dados do Censo 2010 das capitais brasileiras

\begin{tabular}{|c|c|c|c|c|c|c|c|c|}
\hline \multirow[t]{2}{*}{ Capital } & \multicolumn{2}{|c|}{$\begin{array}{c}\text { Vereadores } \\
\text { evangélicos } \\
(\%)\end{array}$} & \multicolumn{6}{|c|}{ Censo $2010(\%)^{46}$} \\
\hline & 2012 & 2016 & Católicos & Evangélicos & Espíritas & Afro & Outras & S/religião \\
\hline Rio Branco & 23,52 & 23,52 & 40,44 & 39,54 & 1,02 & 0,05 & 3,25 & 15,51 \\
\hline Manaus & 31,70 & 34,14 & 54,10 & 35,19 & 0,76 & 0,09 & 3,02 & 6,74 \\
\hline Palmas & 26,31 & 36,84 & 54,56 & 32,70 & 1,84 & 0,02 & 3,18 & 7,79 \\
\hline Porto Velho & 9,52 & 23,80 & 48,75 & 32,16 & 1,16 & 0,11 & 3,26 & 13,75 \\
\hline Boa Vista & 9,52 & 14,28 & 46,96 & 32,09 & 3,62 & 0,15 & 4,27 & 14,89 \\
\hline Goiânia & 14,28 & 14,28 & 51,25 & 32,07 & 4,42 & 0,1 & 3,05 & 9 \\
\hline $\begin{array}{l}\text { Campo } \\
\text { Grande }\end{array}$ & 34,48 & 20,68 & 51,93 & 30,22 & 3,65 & 0,27 & 3,30 & 10,38 \\
\hline Vitória & 33,33 & 33,33 & 54,57 & 29,19 & 2,77 & 0,16 & 2,55 & 10,61 \\
\hline Belém & 11,42 & 17,14 & 62,32 & 28,24 & 1,6 & 0,2 & 2,14 & 5,35 \\
\hline Macapá & 8,69 & 13,03 & 65,33 & 26,59 & 0,61 & 0,12 & 1,92 & 5,35 \\
\hline Cuiabá & 16 & 16 & 58,67 & 26,33 & 3,26 & 0,13 & 3,85 & 7,6 \\
\hline Recife & 17,94 & 25,64 & 54,74 & 24,80 & 3,68 & 0,25 & 2,23 & 14,21 \\
\hline $\begin{array}{c}\text { Belo } \\
\text { Horizonte }\end{array}$ & 26,82 & 31,70 & 60,32 & 24,6 & 4,15 & 0,17 & 2,66 & 7,95 \\
\hline Curitiba & 28,94 & 21,05 & 62,36 & 24,03 & 2,80 & 0,26 & 3,69 & 6,71 \\
\hline João Pessoa & 25,92 & 22,22 & 63,62 & 23,87 & 1,77 & 0,16 & 2,3 & 8,01 \\
\hline Maceió & 19,04 & 4,76 & 62,26 & 23,5 & 1,41 & 0,15 & 2,23 & 10,36 \\
\hline São Luís & 16,12 & 12,90 & 66,22 & 23,47 & 0,65 & 0,12 & 1,93 & 7,45 \\
\hline $\begin{array}{l}\text { Rio de } \\
\text { Janeiro }\end{array}$ & 17,64 & 17,64 & 51,47 & 23,05 & 6,05 & 1,32 & 4,54 & 1,32 \\
\hline São Paulo & 12,72 & 27,27 & 58,47 & 21,88 & 4,84 & 0,63 & 4,82 & 9,20 \\
\hline Fortaleza & 16,27 & 11,62 & 68,22 & 21,12 & 1,33 & 0,22 & 2,47 & 6,50 \\
\hline Natal & 10,34 & 10,34 & 67,64 & 20,65 & 1,86 & 0,08 & 1,89 & 7,79 \\
\hline Salvador & 13,95 & 18,60 & 51,94 & 19,42 & 3,33 & 1,08 & 6,57 & 17,28 \\
\hline Aracaju & 20,83 & 8,33 & 70,89 & 15,15 & 2,81 & 0,41 & 2,39 & 8,12 \\
\hline Teresina & 20,68 & 10,34 & 79,13 & 13,25 & 0,88 & 0,15 & 2,06 & 4,4 \\
\hline Florianópolis & 8,69 & 4,34 & 63,68 & 12,81 & 7,48 & 0,66 & 3,39 & 11,76 \\
\hline Porto Alegre & 11,11 & 13,88 & 63,85 & 11,65 & 7,03 & 3,35 & 3,64 & 10,38 \\
\hline
\end{tabular}

Fonte: Quadro elaborado pelos autores.

${ }^{46}$ Disponível em: <http://censo2010.ibge.gov.br/>. Acesso em: 15 dez. 2016. 
Como podemos observar, os dados indicam uma correlação entre a presença evangélica e sua proporção nas Câmaras de Vereadores. Em outras palavras, as capitais com maior representatividade evangélica tenderam a aumentar o número de representantes deste segmento. E, contrariamente, as capitais com menor representatividade evangélica, também tenderam a diminuir o número de eleitos deste segmento religioso. Neste ponto devemos considerar a constituição histórica de áreas de influência das principais denominaçóes. Assim, observamos uma maior presença da IURD em alguns centros urbanos regionais, como Salvador/BA, Rio de Janeiro/RJ, São Paulo/ SP e Porto Alegre/RS. Trata-se de grandes metrópoles onde se encontra uma ampla camada da população empobrecida, suscetível para buscar na religião a solução para os seus problemas e aflições. Igualmente, trata-se de cidades onde há uma importante presença das religióes de matriz africana, sendo estas o alvo preferencial da guerra espiritual que move a IURD (Silva, 2007). Já a Assembleia de Deus, fundada em Belém em 1911, possui forte influência no norte, sendo procurada pela maioria dos prefeitos eleitos como importante apoiadora na busca do seu sucesso eleitoral.

Em termos de gênero, nas eleiçóes municipais de 2016 a participação feminina manteve-se relativamente estável. As candidaturas de mulheres passaram de 32,5\% em 2012, para 31,89\% em $2016^{47}$. No entanto, devemos recordar que o número de mulheres eleitas ainda é bastante baixo, apenas $13 \%$ dos cargos. É de interesse imediato para o foco deste artigo frisar que embora a participação feminina nos segmentos evangélicos tenha sido inferior à média nacional do conjunto dos partidos, apenas $23,87 \%$, entre os eleitos ela foi superior, $18,54 \%^{48}$, contra $13 \%$ no quadro mais geral, o

47 Alteração na Lei no $12.034 / 2009$ reforçou a obrigatoriedade dos partidos de reservar $30 \%$ das candidaturas para mulheres, o que levou a uma série de casos de suspeitas de candidaturas fantasmas, ou seja, candidatas que se escreveram apenas para fechar as cotas do partido.

${ }^{48}$ Recordando que estes números devem ser relativizados por não representarem uma contagem absoluta. 
que em um momento de crescimento do conservadorismo e da militância antifeminista, pode parecer um contrassenso. No entanto, sugerimos que tal crescimento está associado diretamente à necessidade de dar conta da crescente demanda pelos direitos da mulher, nicho que é usualmente ocupado pelos movimentos feministas. Neste sentido, há ao menos uma década observa-se um crescimento do protagonismo feminino em alguns segmentos evangélicos, como o Batista e principalmente o neopentecostal, agora náo mais como sujeitos relativamente passivos, mas como porta vozes de uma moralidade nem sempre conservadora.

Como exemplo de tal dinâmica pode-se chamar a atenção para o crescimento do protagonismo feminino nas mídias neopentecostais, assim como o surgimento de lideranças femininas, embora figurando quase sempre em posição subalterna a uma liderança masculina. Dentro desta mesma lógica testemunhamos nos últimos anos o crescimento dentro dos partidos conservadores de espaços partidários voltados para a mulher, além do surgimento de um partido específico, o PMB (Partido da Mulher Brasileira), de ideologia conservadora ${ }^{49}$.

Ainda dialogando com a temática do gênero e dentro da lógica familiar bastante presente na política brasileira, destacamos que na maioria dos casos acima mencionados, as candidatas são esposas ou filhas de lideranças evangélicas, valendo-se, muitas vezes, mas nem sempre, do prestígio ou carisma pessoal de seus esposos ou pais. Em muitos casos estas candidatas ocupam o espaço deixado pelo familiar que assumiu outras esferas, como nos Legislativos estaduais, ou mesmo na Câmara Federal, contribuindo dali para a campanha de sua sucessora em nível municipal. Também devemos salientar que uma especificidade destas candidatas, especialmente no segmento neopentecostal, constitui-se em que ao contrário dos homens, elas não pertencem à hierarquia eclesial. Na maioria dos casos são lideranças de segmentos específicos das denominaçôes, como grupos de mulheres, administradoras e missionárias.

${ }^{49} \mathrm{O}$ partido foi fundado em 2008, mas só conseguiu o seu registro definitivo no TSE em 2015.

Debates do NER, Porto Alegre, Ano i 8, N. 32, P. I 5-68, Jul./Dez. 20 I 7 
Já entre denominaçôes pentecostais menores e independentes é comum encontrar lideranças femininas, como pastoras, bispas e apóstolas.

Cabe ressaltar que os candidatos católicos na maioria dos casos só assumem atitude militante comparável à dos evangélicos quando estão ligados a movimentos como a Renovação Carismática Católica. Nos demais casos, seu pertencimento é insinuado sutilmente ou mencionado com pouca ênfase. Outro aspecto das candidaturas católicas está associado às divisóes ideológicas dentro da própria instituição, ou seja, há candidatos que pertencem a uma ala conservadora e há candidatos associados a posiçóes mais progressistas, principalmente aqueles que iniciaram as suas práticas políticas sob influência da Teologia da Libertação nas CEBs (Comunidades Eclesiais de Base). Nestes casos, vinculam-se, em sua maioria, a partidos de esquerda, sobretudo ao PT. Lembrando ainda que foram aqui considerados somente os candidatos que explicitaram o seu pertencimento durante a campanha eleitoral. É certo que a maioria dos candidatos preferiu náo mencionar o seu pertencimento religioso, seja por valorizarem a laicidade seja por entenderem que acionar explicitamente o seu pertencimento religioso poderia náo ser uma estratégia eleitoral que reverteria em benefícios nas urnas.

No caso dos candidatos afrorreligiosos sua presença é pequena, inexistente ou velada na grande maioria das capitais. No entanto, como já dissemos acima, ao menos em Salvador/BA, Rio de Janeiro/RJ e Porto Alegre/RS, esses se apresentaram de forma significativa, sendo que na capital baiana dois deles foram eleitos. Sugerimos que nestas cidades esta disposição para o político eleitoral está diretamente ligada a uma maior organização deste segmento religioso, associado, também ao número de adeptos dessas religiôes existentes naquelas metrópoles ${ }^{50}$. Os afrorreligiosos têm também acionado como

50 Segundo o Censo 2010, as três capitais com maior presença afrorreligiosa no Brasil são as acima referidas: Porto Alegre com 3,35\%, Salvador com 0,89\% e o Rio de Janeiro com $0,34 \%$. No entanto, estas porcentagens devem ser relativizadas e provavelmente aumentadas uma vez que dizem respeito à autoafirmação estando esta sujeita a situaçóes histórico-culturais e especificidades locais, como nos adverte Reginaldo Prandi (2003).

Debates do NER, Porto Alegre, ano i 8, N. 32, P. I 5-68, Jul./Dez. 2017 
bandeira de ingresso no político institucional as possibilidades de reverter nesta esfera, e na instância jurídica, os ataques que sofrem diuturnamente de parte dos segmentos pentecostais e neopentecostais. Também mobilizam a narrativa de poderem atuar na instância política contra concepçóes evolucionistas ou racistas para assegurarem, baseados no princípio democrático da liberdade religiosa, a reprodução de suas práticas religiosas, sobretudo a sacralização de animais. ${ }^{51}$

Finalizando, pôde-se constatar mais uma vez, no contexto das eleições municipais de 2016, a estreita relação entre o religioso e o político, mostrando, como dissemos no início deste texto, a existência de uma porosidade de suas fronteiras. Obviamente que esta imbricação entre religião e política reforça a relevância do religioso no espaço público, sendo isto um componente cultural não somente do Brasil mas, como destaca Pablo Semán, também das sociedades latino-americanas. Este lado "não moderno" dessas sociedades, destaca o antropólogo argentino, constitui um "plâncton" que aproxima religião e política. Segundo as suas palavras:

O lado culturalmente "não moderno" das sociedades latino-americanas contemporâneas é uma base, um plâncton, que nutre o impulso religioso que se projeta na esfera pública ou pode ser trazido a ela pelos apelos de políticos e candidatos. Não é por acaso que o eleitorado popular responde tanto a apelos que sublinham a santidade do candidato quanto a possibilidade de ele ser metaforizado ou referido diretamente como um "homem de Deus". Ainda mais quando se considera que essa faixa "não moderna" das sociedades latino -americanas não apenas implica a existência de uma forte visão cosmológica, mas, também, uma perspectiva que entende a divisão entre público e privado de uma forma muito diferente da tradição liberal, que instaura essa divisão, e que leva a ver esse homem de Deus ao mesmo tempo como um bom pai de família. Do ponto de vista "tradicional", público e privado se conectam fluidamente através de formas de entender os papéis familiares, que chamamos privados (Semán, 2006, p. 21-22).

${ }^{51}$ A este respeito ver Oro (2005) e Oro e Carvalho (2015). 
Enfim, para retomar a questão da secularização, também anunciada na introdução deste texto, podemos afirmar, juntamente com Pierucci, que no Brasil, e na America Latina, a secularização do Estado no seu ordenamento jurídico (disestablishment) não coincide com a secularização da vida das pessoas. Ou seja, "secularização no plano jurídico-estatal, vitalidade religiosa no plano sociocultural" (Pierucci, 2012, p. 90).

\section{REFERENCIAS}

ACQUAVIVA, Sabino. L'Eclissi del sacro nella civiltà industriale. Milano: Edizioni di Comunità, 1961.

BERGER, Peter. $O$ dossel sagrado: elementos para uma teoria sociológica da religião. São Paulo: Editora Paulinas, 1985.

- A dessecularização do mundo: uma visão global. Religião \& Sociedade, Rio de Janeiro, v. 21, n. 1, p. 10-24, 2000.

BURITY, Joanildo. Identidade e política no campo religioso. Estudos Sociedade e Agricultura, Rio de Janeiro, n. 9, out. 1997/mar. 1998.

BURITY, Joanildo; MACHADO, Maria das Dores Campos. Os votos de Deus: evangélicos, política e eleições no Brasil. Recife: Fundação Joaquim Nabuco; Editora Massangana, 2006.

HERVIEU-LÉGER, Daniele. Vers un nouveau christianisme? Paris: Cerf. 1987.

LIMA, Antônio J. F. de et al. Vereadores católicos: elementos para a reflexão sobre a diversidade articulada no campo político. Debates do NER, Porto Alegre, ano 5, v. 2, n. 6, p. 35-62, dez. 2004.

MACHADO, Maria das Dores Campos; BURITY, Joanildo. A Ascensão Política dos Pentecostais no Brasil na Avaliação de Líderes Religiosos. Dados, Rio de Janeiro, v. 57, n. 3, p. 601-631, 2014. 
MARIANO, Ricardo; ORO, Ari Pedro. Religion and Politics in Brazil. In: SCHMIDT, Bettina; ENGLER, Steven. Handbook of Contemporary Religions in Brazil. London: Brill, 2016. p. 363-378.

MARIZ, Cecilia. Secularização e dessecularização: comentários a um texto de Peter Berger. Religiäo \& Sociedade, Rio de Janeiro, v. 21, n. 1, p. 25-39, 2000. ORO, Ari Pedro. A política da Igreja Universal e seus reflexos nos campos religioso e político brasileiros. Revista Brasileira de Ciências Sociais, São Paulo, v. 18, n. 53 , p. 53-69, 2003 a.

. "Religious Politicians" and "Secular Politicians" in Southern Brazil. Social Compass, Louvain, v. 54, n. 4, p. 583-592, 2007.

. O sacrifício de animais nas religiôes afro-brasileiras: análise de uma polêmica recente no Rio Grande do Sul. Religiäo \& Sociedade, Rio de Janeiro, v. 25, n. 2, p. 11-31, 2005.

ORO, Ari Pedro; MARIANO, Ricardo. The reciprocal instrumentalization of Religion and Politics in Brazil. In: MICHEL, Patrick; PACE, Enzo (Ed.). Religion and Politics. Paris; Padua: Brill, 2011. p. 245-266. (Annual Review of the Sociology of Religion, v. 2.)

ORO, Ari Pedro; CARVALHO, Erico Tavares de. Eleiçóes gerais de 2014: religiáo e política no Rio Grande do Sul. Debates do Ner, ano 16, v. 1, n. 27, p. $145-172,2015$.

- A reincidência da polêmica sobre o sacrifício de animais nas regióes afro-brasileiras do Rio Grande do Sul. In: REUNIÓN DE ANTROPOLOGÍA DEL MERCOSUR: DIÁLOGOS, PRÁCTICAS Y VISIONES DESDE EL SUR, 11., 2015, Montevideo. Atas... Montevideo: Universidad de la Republica, 2015. Disponível em: <http://xiram.com.uy/actas-delcongreso/mesas-redondas/ponencias-mesa-redonda-24>. Acesso em: 12 nov. 2016. 
PEDDE, Valdir. “Cabeça, sim; cauda, não!': um estudo antropológico sobre os evangélicos na Assembléia Legislativa do Rio Grande do Sul. 2005. 415 f. Tese (Doutorado em Antropologia Social)-Instituto de Filosofia e Ciências Humanas, Universidade Federal do Rio Grande do Sul, Porto Alegre, 2005. PIERUCCI, Antônio Flávio. O crescimento da liberdade religiosa e o declínio da religião tradicional: a propósito do censo 2010. Anuac, v. 1, n. 2, p. 87-96, nov. 2012.

SÉMAN, Pablo. Introdução. In: Oro, A. P. (Org.). Religião e política no Cone-sul. São Paulo: Attar Editorial, 2006. p. 9-31.

SILVA, Vagner G. (Org.). Intolerância Religiosa: impactos do neopentecostalismo no campo religioso afro-brasileiro. São Paulo: Edusp, 2007.

TADVALD, Marcelo. A reinvenção do conservadorismo: os evangélicos e as eleiçôes federais de 2014. Debates do NER, Porto Alegre, ano 16, n. 27, p. 259-288, 2015.

TREVISAN, Janine. A frente parlamentar evangélica: força política no estado laico brasileiro. Numen: revista de estudos e pesquisas em religião, Juiz de Fora, v. 16, n. 1, p. 581-609, 2013.

VASCONCELOS, Marta Chaves; MAGALHĀES, Ana Cristina Macedo; CASTRO, Eduardo Bernardes de. A importância do perfil dos vereadores na Governança Pública. O caso de Curitiba no ano de 2013. In: SEMINÁRIO NACIONAL DE PLANEJAMENTO E DESENVOLVIMENTO, 1., 2013, Curitiba. Anais... Curitiba: UTFPR, 2013. Disponível em: <http://200.19.73.116/anais2/wp-content/uploads/2015/08/ Marta_Chaves2.pdf>. Acesso em: 12 nov. 2016. 
WILSON, Bryan. The secularization thesis: criticisms and rebuttals. In: LAERMANS, Rudy; WILSON, Bryan; BILLIET, Jaak. Secularization and Social Integration: Papers in Honor of Karel Dobbelaere. Leuven: Leuven University Press, 1998. p. 45-65.

Recebido em: 04/04/2017 Aprovado em: 04/04/2017 
COMENTÁRIOS 



\section{ALGUMAS QUESTÓES INSPIRADAS PELAS ELEIÇÕES MUNICIPAIS DE 2016: COMENTANDO O ARTIGO DE ERICO TAVARES DE CARVALHO JUNIOR E ARI PEDRO ORO}

\section{Cecília Loreto Mariz ${ }^{1}$}

A política parece ser uma das dimensóes da vida social brasileira mais afetadas pela transformação do perfil religioso da população. Daí o grande número de estudos que buscam analisar a relação entre religião e política no Brasil, e que analisam mais especificamente, a relação entre evangélicos e política $^{2}$. Nesse período atual de intensas transformaçóes e tensóes políticas pelas quais o país passa, a cada dia há novidades que mudam alianças e configuraçóes políticas. Necessitam-se dados recentes constantemente. Portanto, é muito bem vindo o artigo de Erico Tavares de Carvalho Junior e Ari Pedro Oro com dados muito variados e ricos sobre as últimas eleições municipais de 2016. A pesquisa, que o artigo apresenta, tem várias qualidades, que a destacam e a tornam muito útil para ajudar a entender essa questão no Brasil contemporâneo. Além de recentes, seus dados refletem a situação do país como todo, já que foram coletados em todas as capitais. Também os seus dados quantitativos sobre resultados eleitorais dos candidatos a prefeitos e, além disso, os dos candidatos a vereadores, que se apresentaram com uma identidade religiosa, foram complementados com dados qualitativos sobre o contexto político de cada capital, o perfil dos candidatos a prefeitos e as alianças políticas que os elegeram. Também, diferentemente da grande parte da literatura sobre religião e política, essa pesquisa, como já foi dito, não se

1 Professora de sociologia no Departamento de Ciências Sociais da Universidade do Estado do Rio de Janeiro (UERJ). Contato: marizcecilia@gmail.com

2 Nas referências bibliográficas do texto de Tavares Jr. e Oro encontra-se listada grande parte desses trabalhos. 
reduz a estudar os evangélicos, mas pela importância que esse grupo toma no campo há mais dados e reflexôes sobre ele no artigo analisado.

Em termos genéricos, identificam-se duas variedades de pesquisas sobre evangélicos na política no Brasil. A primeira se volta para atuação, agenda proposta, discursos de legisladores evangélicos, enquanto a segunda avalia desempenho eleitoral desses políticos e a possível origem dos votos que os elegeram. Somando-se a esse último tipo de pesquisa, o artigo de Erico Tavares de Carvalho Junior e Ari Pedro Oro, que estuda as eleições municipais nas 26 capitais do país, se distingue da maior parte das pesquisas realizadas nesse campo que tem como foco as eleiçóes para as câmaras federais e estaduais, mas especialmente federais. Essa relativa ausência de estudos sobre desempenho eleitoral de candidatos a prefeitos e vereadores com identidade religiosa resulta numa lacuna que já tende a ser preenchida pelo presente estudo.

Como são as câmaras federais as encarregadas de legislar sobre as questóes relacionadas às agendas de grupos religiosos, em especial dos evangélicos e católicos, que se posicionam contra, por exemplo, a legalização do aborto, as eleiçóes para essas casas despertavam mais interesses de pesquisa. No entanto, a situação tem se modificado. Os evangélicos têm seus projetos para o executivo embora menos justificados pelas agendas políticas que em geral apresentam relacionadas às legislaçôes sobre família e vida moral. A prefeitura é um primeiro degrau no poder executivo e nesse sentido ganha importância também simbólica. Com efeito, eleição de prefeitos evangélicos já ocorria por muitos anos em cidades menores, mas a eleição de 2016 se destaca por conduzir um Bispo da Igreja Universal do Reino de Deus à prefeitura da ex-capital do Brasil, o Rio de Janeiro. A pesquisa de Tavares Jr. e Oro identifica também outros prefeitos evangélicos em capitais ${ }^{3}$.

3 Os autores identificam mais três, entre esses um que parece ter se tornado evangélico depois de eleito. Outro que dizem que é evangélico, mas ele próprio não afirmava isso na campanha.

Debates do NER, Porto Alegre, ano i 8, N. 32, P. 7 I-80, JUl./Dez. 20 I 7 
Somada à questão sobre o tipo de propostas e agenda que adotariam os candidatos ao executivo, em geral, e no caso específico a prefeitos, também pode se perguntar sobre a agenda apresentada pelos candidatos a vereadores. Um candidato a vereador não pode adotar a mesma plataforma moral de luta contra a legalizaçáo do aborto, por exemplo: não há como se colocar defendendo as mesmas bandeiras das eleiçóes federais. O que já foi observado e que hipóteses se colocam? Talvez esse tipo de eleição deixará mais evidente a força do simples compartilhamento de identidade religiosa, ou seja, do lema "irmão vota em irmão". Nesse caso não se precisa focar atenção no que esses candidatos propóem. Mas se a identidade seria assim importante, seria interessante se perguntar em que medida o discurso identificado por Joanildo Burity $(2015)^{4}$, por parte de políticos evangélicos, que coloca esse grupo religioso com uma minoria que precisa defender, seria acionado nas campanhas? Esse processo que o autor acima chamou de "minoritização da identidade evangélica” teria ressonância nas campanhas? Ou estariam as campanhas no nível municipal voltada para os interesses das áreas onde vivem os evangélicos que são, em geral, as mais pobres das cidades? E o que mais mobilizaria o voto evangélico? Para ter mais clareza do sentido desse voto seriam necessárias novas pesquisas tanto sobre os argumentos dos eleitores para escolher votar em um evangélico como também os argumentos da campanha para angariar votos por parte desses candidatos.

O comentário acima não deve ser de forma alguma interpretado como demanda de mais dados que deviam ter sido coletados nessa pesquisa ou apresentados no texto. O que não se criticaria nesse texto de forma alguma seria a falta de dados, muito pelo contrário. $\mathrm{O}$ artigo chama atenção pela variedade e quantidades de dados e já há dados mais do que suficientes. Disponibilizados em numerosas tabelas, os dados permitem comparaçóes de vários tipos: comparaçóes entre capitais, entre grupos religiosos, gênero, partidos. São tão numerosas as possibilidades de comparaçôes que evidentemente não havia condições de fazer todas em um único texto; os autores,

4 Ver também Machado e Burity (2015), entre outros. 
então, estão oferecendo a oportunidade de novas análises a outros pesquisadores a partir dos seus dados.

A envergadura da pesquisa realizada impressiona. $O$ trabalho de coleta de dados certamente exigiu o esforço de uma equipe integrada e também muito fôlego e tempo. Essa coleta de dados já se iniciou durante a campanha eleitoral, como já mencionado acima, por todas as capitais do país para identificar os candidatos que naquelas eleiçóes adotavam uma identidade religiosa. Os autores comentam que para isso foram analisados os mais diversos tipos de material de campanha de 17 mil candidatos! Após a identificação desses candidatos, foi registrado o desempenho eleitoral de cada um; isso resultou, como já foi dito, em muitas tabelas. A proposta de realizar análises comparativas tornou essa multiplicidade de tabelas com grande quantidade de informação inevitável. Como foi dito, os autores fazem muitas comparaçóes, mas como não há como fazer todas as possíveis em um artigo, eles disponibilizaram generosamente seus dados para o leitor trabalhar sobre eles.

Entre as tabelas comparativas do texto, os autores destacam aquela que relaciona o crescimento da proporção de vereadores evangélicos eleitos em cada capital com a população evangélica de cada uma. Esses dados revelam que há uma tendência de correlação positiva entre as duas variáveis sustentando empiricamente que a mudança no perfil religioso da populaçáo estaria impactando as eleiçóes. Esse processo observado com evangélicos, no entanto, pode não acontecer com outras religióes, como mostra também a presente pesquisa. Como foi dito, os autores esclarecem que foi realizada uma prévia e exaustiva análise de material de propaganda eleitoral que lhes permitiu identificar em cada capital os candidatos que nas eleiçóes municipais de 2016 explicitaram a identidade religiosa durante a campanha. Dessa forma encontram, além dos candidatos evangélicos e católicos, candidatos que acionavam outras identidades, como a afrorreligiosa, a esotérica, a judaica e a espírita. No caso do espiritismo, foi encontrado apenas um candidato. O espiritismo tem crescido, como apontou o último censo no Brasil como um todo e mais fortemente em algumas capitais, mas talvez as doutrinas e 
visão de mundo dessa religião não levem esse grupo para a política como ocorreu com os evangélicos. O que sugerem é que talvez o alto percentual de espíritas tenha resultado em maior rejeição dos evangélicos.

Trazendo mais dados de pesquisa para o caso de Porto Alegre, os autores realizaram uma análise mais detalhada sobre cada um desses candidatos incluindo os que perderam as eleiçôes. A partir desse caso se pode pensar numa tendência de menor sucesso eleitoral de identidades religiosas afro-brasileiras ou esotéricas, talvez não apenas, ou não tanto, pela falta de eleitores, mas também pela multiplicação de candidatos. Em contrapartida, os católicos proporcionalmente apresentam menos candidatos e elegem mais os que concorrem, e em termos relativos, até mais do que os evangélicos. Esse relativo sucesso parece resultar da menor quantidade de candidatos, que sugere maior união, talvez fruto de uma unidade institucional ou da experiência e vivência política desse grupo religioso que historicamente tem marcado mais presença na política, tanto no Brasil e no exterior.

Queria destacar ainda três outros tipos de dados encontrados pela pesquisa que inspiram outras questôes, estimulando reflexóes sobre os possíveis rumos futuros das alianças e perfil setor evangélico na política. $\mathrm{O}$ primeiro deles é a presença de políticos que se identificam como "cristãos" de forma genérica evitando se dizerem especificamente evangélicos e tampouco católicos. Embora a quantidade dos que assumiram esse tipo de identidade (cristã) seja pequena, o simples fato do termo "cristão" ser acionado como distinto em um campo onde se acostumou a falar de "bancadas evangélicas", já pode ser significativo em termos políticos e também religiosos. Indicaria essa identidade de fato um tipo de mobilização política distinta daquela dos que se dizem evangélicos? Estariam esses políticos procurando mobilizar a união de católicos e evangélicos, como tem feito tradicionalmente partidos europeus que se definem como "cristãos"? Qual a relação da adoção dessa identidade com as alianças entre evangélicos e católicos descritas por Maria das Dores Machado (2012) nas câmaras federais para defesa de determinada plataforma de defesa da "família" ou valores sexuais e morais? Somente seria possível saber qual o significado e motivo para assumir essa identidade com 
análise mais detalhada do contexto da candidatura, seus apoios e rede de sustentação e também uma análise do conteúdo da campanha eleitoral. Por exemplo, pode-se lembrar o ex-governador de Pernambuco Eduardo Campos, com vínculos conhecidos com o catolicismo, declarou-se, em sua campanha de 2014 à presidente do Brasil, quando fez aliança com a ex-senadora Marina Silva, "cristão". Essa declaração aparecia em especial quando perguntado sobre sua posição em relação ao aborto.

O que parece ficar claro, contudo, é que esses que se dizem "cristãos" não consideram o termo como sinônimo de protestante ou evangélico, como se fazia no passado recente. Era comum os evangélicos se reservarem o direito de serem chamados de cristãos, excluindo os católicos dessa categoria. Assim, acusavam os católicos de não serem cristãos por sua "idolatria" e outros comportamentos tidos como contrários aos ensinamentos bíblicos. Seria interessante a análise de possíveis novos significados do termo cristão no presente contexto quando se define uma agenda política moral compartilhada por políticos evangélicos e católicos. Seria essa uma tendência que poderia redefinir o campo político levando alguns setores evangélicos para votar nesse tipo de candidatos? Outras pesquisas para averiguar a presença dessa identidade em outros pleitos eleitorais serão necessárias para saber se é uma tendência ou trata-se apenas de experiências isoladas.

O segundo dado também relevante, que interpela na mesma direção sobre alianças, é uma freqüente observação feita pelos autores em suas descriçôes sobre as alianças e estratégias de campanha que elegeram os prefeitos em cada uma das capitais. Os autores recorrentemente afirmam que os evangélicos se dividiram no apoio a tal ou qual candidato. Comentando em cada contexto que evangélicos receberam ou não apoio dos políticos evangélicos, os autores procuram mostrar como esse apoio era importante. No entanto, há um número razoável de casos que os autores se referem à divisão entre as lideranças evangélicas quanto ao candidato escolhido para ser apoiado. Há até o caso de um candidato a prefeito que apesar de sua identidade evangélica, não recebeu de todos setores evangélicos. A desunião entre as lideranças políticas evangélicas já tem sido observada e é fato 
relativamente comum. Análises de outras eleições têm mostrado isso especialmente nas eleiçóes do executivo, como foi o caso por exemplo na última presidencial de 2014. Portanto, a identidade evangélica e religiosa em geral não resulta em defesa de uma única candidatura ou plataforma. Seria essa uma tendência a crescer de que lideranças evangélicas nem sempre peçam votos para os "irmãos"? Em que contextos pode isso ocorrer?

Por outro lado, como foi dito acima, os dados desse artigo sugerem que os fiéis evangélicos parecem preferir candidatos evangélicos. Essa foi uma conclusão inferida pela correlação positiva entre alta proporção de evangélicos na população da cidade e o sucesso dos candidatos com essa identidade religiosa nas eleiçôes municipais analisadas. Assim, evangélicos tendem a votar em candidatos de sua religião e, para o caso deles, o lema "irmão vota em irmão" parece proceder. No entanto, os candidatos supostamente "irmãos" nem sempre estão unidos numa mesma coligação. $\mathrm{O}$ que explicaria a desuniáo? Seria uma questáo de agenda? ou antes pessoal entre lideranças? seria uma estratégia de sempre ter evangélicos aliados ao poder executivo? Se essa desunião for uma tendência, que resultado terá em futuro próximo?

O terceiro dado, que quero destacar aqui, foi mais valorizado pelos autores do que os dois anteriores. Concordo com os autores sobre a relevância desse achado da pesquisa sobre o sucesso relativamente maior das candidaturas femininas evangélicas quando comparado ao sucesso das candidaturas femininas em geral. Para os autores, esse dado poderia se relacionar ao fato de que o campo evangélico também tem experimentado um crescimento do protagonismo feminino. Efetivamente essa observação explicaria um crescimento do número de candidaturas de mulheres evangélicas às eleiçóes que também ocorre. No entanto, o dado, que é relevante aqui, não é mais candidatas, mas maior voto proporcional nessas candidatas. Assim, esse argumento não explicaria o relativo maior sucesso das candidatas evangélicas em relação às mulheres em geral. Além do mais, sendo o feminismo maior na sociedade como um todo, por que os eleitores evangélicos votam mais em mulheres? Sugiro que podemos entender o fato das candidatas evangé- 
licas terem relativamente mais votos por ser tanto a população evangélica, como provavelmente o eleitorado evangélico, formados majoritariamente por mulheres. Assim, o eleitorado evangélico talvez seja mais feminino do que o eleitorado da sociedade mais ampla. Embora náo se esteja dizendo que mulher vá sempre votar em mulher, pode se pensar em uma tendência de mulher votar mais em mulher do que faria um homem. Essa seria uma explicação alternativa para esse dado muito significativo encontrado por essa pesquisa. Outra questáo para pesquisas futuras é se esse tipo de sucesso estimularia mais mulheres a se candidatarem e também a feminização se tornaria uma tendência no campo político evangélico.

Finalmente, gostaria de concluir essas reflexões comentando a interpretaçáo dos autores sobre o que significaria esse destacado papel da identidade religiosa nos pleitos eleitorais que ocorre atualmente no Brasil. Os autores consideram que esse tipo de relação entre política e religiáo se explicaria pela força do "não moderno" na sociedade brasileira. Identificam como náo moderno o fato da maioria de seus habitantes, tal como os da América Latina em geral, serem religiosos e não secularizados. No entanto, gostaria de chamar atençáa que mais do que a secularizaçáo e desencantamento em termos de atribuição de sentido à direçâo da vida pessoal e política, a modernidade tem sido relacionada à convivência de uma multiplicidade de valores, significados ideológicos e também identidades religiosas, cosmovisóes variadas e projetos diversos. A grande queda do catolicismo, que seria a religiosidade mais vinculada à tradiçâao brasileira, e o início de uma sociedade plural indicariam um movimento de afastamento da tradição. Muito tem se questionado sobre o conceito "modernidade", concebido metodologicamente como "tipo ideal" ou como um projeto quase mitológico. Também se tem argumentado sobre os vários tipos de modernidade, como Maria das Dores Machado (2012) analisando a religião e a política no Brasil. As sociedades que são consideradas modernas em geral convivem com religióes universais e éticas e esse tipo de religião náo pode deixar de tentar interferir na política e no estado pois sáo forçadas a isso para defender seus princípios éticos considerados válidos para toda humanidade. Países europeus considerados 
modernos, como a Alemanha e os Países Baixos, possuem partidos que se identificam como cristãos e esses são forças políticas importantes.

Votar em um candidato inspirado por seus princípios éticos-religiosos é muito distinto de defender um estado que seja gerido e absorvido por uma religião específica. A fusão entre política e religião, que ocorre em contextos considerados pré-modernos, é bem distinta da luta por parte de grupos religiosos em arena política entre vários outros grupos políticos religiosos e seculares. O que torna moderna é o fato da disputa ser regida por regras racionais legais e pelos grupos procurarem elaborar discursos com argumentos lógicos racionais e por defenderem projetos em princípio universais. Nas eleiçóes atuais nenhum grupo religioso se coloca com projeto de dominar o estado. Em suas campanhas e em atuação quando eleitos esses políticos, tal como os demais, apelam por valores éticos que consideram universais e que tentam defender racionalmente. Portanto, a opçáo de uma luta política via eleiçáo é uma prática mais moderna do que a usualmente adotada pela igreja católica de influenciar as instituições a partir de diálogos e trocas entre autoridades eclesiais e governamentais. A assinatura de concordata entre a Igreja católica e o governo brasileiro seria em exemplo desse tipo de prática menos democrática e mais vinculada ao estilo histórico da religiáo lidar com o poder. A influência sobre o governo por parte da instituição Igreja era a prática mais usual do passado que pode ser considerada mais vinculada à tradição.

Como já tem sido mostrado por vários autores, a modernidade não extingue a religiáo nem a reduz totalmente ao espaço da vida privada. Essa redução à vida privada significaria o abandono de um projeto ético e social. Uma religiấo preocupada com igualdade e justiça social não pode escapar de se imbricar com a política. Por outro lado, a religião continua como sendo uma das várias identidades possíveis de se adotar em várias sociedades modernas, representando grupos de interesses. A modernidade náo consegue impedir a imbricação entre religião e política, e nem nos países mais seculares, como 
os europeus. A porosidade entre religião e política é inevitável. A política, como a economia e outras esferas da vida social, perpassam a vida religiosa e a religião em princípio sempre tentará que essas dimensóes se submetam aos seus projetos e valores.

\section{REFERÊNCIAS}

BURITY, Joanildo. Políticas de minoritização religiosa e glocalização: notas para um estudo de redes religiosas de ativismo socio-político transnacional. Revista Latinoamericana de Estudios sobre Cuerpos, Emociones y Sociedad, Montevideo, ano 7, n. 18, p. 19-30, ago./nov. 2015.

MACHADO, Maria das Dores Campos; BURITY, Joanildo. A Ascensão Política dos Pentecostais no Brasil na Avaliação de Líderes Religiosos. Dados, Rio de Janeiro, v. 57, n. 3, p. 601-631, 2014.

. Religião, Cultura e Política. Religião e Sociedade, Rio de Janeiro, v. 32, n. 2, p. 29-56, 2012.

Recebido em: 07/08/2017 Aprovado em: 07/08/2017 


\section{A RELIGIÃO E AS ELEIÇÕES MUNICIPAIS BRASILEIRAS DE 2016: A VERDADEIRA NOVIDADE}

Paul Freston ${ }^{1}$

O texto de Tavares e Oro nos oferece dados extremamente valiosos para mapear e entender a participação religiosa na vida eleitoral brasileira, sobretudo porque o nível municipal é ao mesmo tempo o mais difícil (porque fragmentado) de pesquisar e, em certo sentido, o mais democrático (porque acontece em circunscriçôes eleitorais menores e, portanto, mais acessíveis a uma diversidade maior de candidatos). Evidentemente, os autores nos dão uma fotografia e não dados longitudinais (exceto quando é possível reconstitui-los a partir de outras fontes). Vemos o atleta correndo, mas não vemos se ele está acelerando ou desacelerando, se está correndo com facilidade ou com dificuldade, se controla a corrida ou se apenas reage às iniciativas dos outros corredores.

O texto faz um esforço para incluir todas as confissóes, uma tarefa nada fácil em parte pela amplitude exigida, mas acima de tudo pelos problemas metodológicos que implica. $\mathrm{O}$ texto não se delonga numa discussão da dificuldade de definir um candidato "católico" em contraposição a um "evangélico", mas a questão é extremamente complicada, a ponto quase de anular a utilidade da comparação. Por outro lado, o texto reconhece acertadamente que os candidatos católicos assumem atitude militante comparável a dos evangélicos quando ligados de alguma forma ao catolicismo carismático. Essa participação mais explicitamente católica deverá seguir aumentando, mais ou menos na mesma velocidade da diminuição da proporção católica na população. Como sabemos, alguns estados e municípios já têm minorias

1 Professor catedrático em Religião e Política em Contexto Global na Balsillie School of International Affairs, Wilfred Laurier University, Canada, e professor colaborador no Programa de Pós-Graduação em Sociologia da Universidade Federal de São Carlos. Contato: pfreston@gmail.com 
católicas. Mas o grau de explicitação da identidade católica, como de qualquer identidade religiosa, depende não apenas de uma relação inversa com a sua proporção na população, mas também de outros fatores, tais como uma certa "tradição" em cada segmento confessional a respeito do que é considerado "de bom tom" na articulação entre identidade religiosa e candidaturas políticas. Em cada confissão há uma certa inércia tradicionalista nesse sentido, a qual dificulta a consecução das mudanças indicadas pela realidade mutável das relaçóes dentro do campo religioso e em termos da sua imagem na sociedade como um todo.

A predominância carismática nesse tipo de identificação político-religiosa mais "evangélica” faz sentido, pois o catolicismo carismático é por excelência um catolicismo apropriado para um contexto em que a Igreja Católica se encontra cada vez mais como uma denominação entre outras, e não mais como "a Igreja” em sentido único. É um jeito de ser católico, nascido não por acaso nos Estados Unidos onde o catolicismo sempre teve que concorrer num contexto denominacionalista plural. É uma das formas do catolicismo brasileiro se adaptar à nova realidade social e religiosa do país e, embora com certo atraso e remando contra a inércia tradicionalista já mencionada, o estilo carismático de fazer política tenderá a crescer em importância como uma arma cada vez mais potente no arsenal católico extremamente variado de opçóes para exercer a sua influência no campo político. Mas é pouco provável que a hierarquia queira apostar muitas fichas nesse estilo carismático de fazer política, a ponto de deixá-lo tornar-se a forma predominante, como tem acontecido com os evangélicos, porque a hierarquia dispóe de outras armas e resistirá à "tentação" de ser vista como igualada aos evangélicos.

Vemos que os evangélicos controlam 5 das 26 capitais: Rio de Janeiro, Goiânia, Campo Grande, São Luís e Rio Branco. Isso representa um número um pouco abaixo do "esperado" (sete) pela sua porcentagem na população. Eram 22,2\% no censo de 2010 e sabidamente continuam crescendo; foram detectados em 26\% na pesquisa do Pew Fórum de 2014. Claro que a proporçáo demográfica pode não ser exatamente a proporçáo do eleitorado, 
devido à composição etária diferente de cada confissão; mas esta não deve discrepar muito daquela para as religióes maiores. Estes dados, então, nos dão uma base para colocar o desempenho eleitoral de cada confissão dentro de uma certa expectativa realista. Isso se aplica sobretudo aos evangélicos, devido à sua "segunda posição" no campo confessional, portanto minoritária mas ainda em crescimento acelerado, e a natureza da sua vida religiosa, constituída amplamente em congregaçóes e denominaçóes relativamente sólidas. No entanto, é de notar a mudança nesse campo no sentido de uma identidade "evangélica" desdenominacionalizada, já detectada no censo de 2010 e que agora passa a se refletir largamente na prática cada vez mais comum de candidatos se identificarem como genericamente "evangélicos", sem rótulo denominacional. Vinte e cinco dos 154 vereadores eleitos nas 26 capitais estaduais (meus totais diferem um pouco dos autores, mas utilizo os dados deles para cada cidade) são identificados no texto apenas dessa forma. Pode haver várias razóes para isso, inclusive estratégias de maximização do voto evangélico por candidatos evangélicos atuantes que não disponham de base eleitoral suficiente nas suas próprias denominaçôes; ou mesmo a invocaçáo de uma identidade evangélica genérica por evangélicos pouco atuantes que desejem dar mais lastro a suas candidaturas.

A categoria genérica de "evangélico" complica um pouco a análise fascinante dos vereadores eleitos que fazem Tavares e Oro. Mesmo assim, conseguem construir um quadro altamente informativo. Em todas as capitais há vereadores evangélicos, mas o número oscila enormemente, entre apenas 1 em Maceió e Florianópolis, para 13 em Belo Horizonte, 14 em Manaus e 15 em Sáo Paulo. Evidentemente, o tamanho das respectivas Câmaras Municipais influi nesses resultados, mas é digna de nota a quase ausência de vereadores evangélicos em uma capital do Nordeste (tradicionalmente a regiáo mais resistente ao avanço evangélico) e uma do Sul (o qual, nos seus dois estados mais meridionais, constitui hoje o Brasil menos suscetível ao crescimento protestante, uma vez subtraído o efeito da antiga imigraçáo de protestantes históricos europeus, chegando a ser um Brasil mais "Cone Sul" na sua conformaçáo religiosa). Na outra ponta da escala, a presença 
de São Paulo (além do mais, pelo tamanho) e de Manaus (maior representante da Região Norte, a mais evangélica) não surpreendem. Mas, sim, a de Belo Horizonte, refletindo talvez o recente avanço evangélico na outrora resistente Minas Gerais.

A região Nordeste, tradicionalmente resistente ao protestantismo, agora desenvolve um perfil mais diverso: as grandes metrópoles nordestinas começam a parecer mais com o restante do país, mas as capitais menores mudaram menos. Quanto à região Centro-Oeste, os resultados municipais são altamente contraditórios: um retorno relativamente pequeno em vereadores evangélicos, mas os melhores resultados do país nos pleitos majoritários. Em Goiânia, o primeiro e segundo colocados para prefeito são evangélicos; em Campo Grande deu-se o mesmo, sendo que o vice-prefeito eleito também o é.

Aliás, a porcentagem de vereadores evangélicos supera a média de evangélicos na população do município em apenas seis capitais: Palmas, Vitória, Recife, Belo Horizonte, São Paulo e Porto Alegre.

Em termos da composição denominacional dos vereadores evangélicos, a Assembleia de Deus (entende-se, Missão, já que Madureira é contada separadamente) detém uma pluralidade, como seria de esperar, com 42 eleitos nas capitais. Em seguida vem a Universal do Reino de Deus com 30 , resultado que representa um desempenho mais "eficiente", proporcional ao número de membros, do que o da $\mathrm{AD}$. Outros pentecostais somam 26, com destaque para os 5 eleitos da Quadrangular, 4 da Internacional da Graça de Deus e 3 da AD Madureira. Com isso, os claramente pentecostais constituem 98 dos 154 evangélicos eleitos. Mas é possível que outros sejam, já que 25 são definidos apenas como "evangélicos". Os claramente históricos são apenas 31, dos quais 7 adventistas, 5 presbiterianos e 2 luteranos. Mas a força dos históricos depende sobretudo dos 17 vereadores batistas. Mesmo assim, batistas se elegem em apenas dez capitais (quatro em Belo Horizonte), ao passo que assembleianos e universais vencem em 20 capitais cada, mostrando o caráter nacional de sua distribuição.

O texto de Tavares e Oro enfatiza os "partidos cristãos", mas a sua relevância é dúbia. Nenhum deles chega a ser "partido cristão" no sentido 
clássico, sobretudo num contexto partidário extremamente fragmentado e pouco ideológico, e nenhuma grande denominação concentra a sua atuação eleitoral neles.

Quanto à questão ideológica maior, os autores acertadamente concluem que não se constitui numa variável determinante para obter maior ou menor apoio dos evangélicos. De fato, em Vitória o prefeito de esquerda se reelegeu com o apoio de um senador batista e de alguns partidos cristáos. Em Belém, o segundo colocado para prefeito, pelo PSOL, recebeu apoio de meios evangélicos, principalmente da $\mathrm{AD}$. E o único prefeito que o PT elegeu em capital estadual em 2016, na cidade de Rio Branco, congrega na Igreja Batista. O quadro brasileiro continua complexo demais para falarmos numa "direita cristâ" que seja determinante no comportamento eleitoral evangélico no Brasil.

Enquanto isso, não resta dúvida em que reside a verdadeira novidade político-religiosa do pleito de 2016: a eleiçáo de Marcelo Crivella para prefeito do Rio de Janeiro. Nunca antes um político pentecostal havia conquistado, pela via eleitoral majoritária, um posto táo importante no Brasil. O corporativismo eleitoral pentecostal, capitaneado desde 1986 pela $\mathrm{AD}$ e pela IURD, por mais bem sucedido que fosse em eleiçôes proporcionais, sempre funcionou como estorvo às aspiraçôes majoritárias, devido à insuficiência de votos evangélicos para vencer eleiçôes para postos executivos em segundo turno e ao alto índice de rejeiçấo geralmente criado pela forte identificação sectária de candidatos pentecostais "oficiais" na vida pública. $\mathrm{O}$ problema havia afligido o próprio Crivella em suas três tentativas anteriores para prefeito ou governador. Em 2016, no entanto, a barreira foi finalmente superada. Sem dúvida, colaborou para isso o crescimento evangélico na populaçáo do Rio de Jeneiro, além do paciente trabalho de "normalização" política da figura de Crivella, já senador há 14 anos, e até de "normalização", ao menos parcial, da presença da IURD na sociedade brasileira (já vai longe o "chute na santa" e outros incidentes). Mas é improvável que tudo isso bastasse em tempos normais. A conjuntura política anormal de 2016, 
pós-impeachment; a ausência de uma forte candidatura peemedebista no pleito carioca; a passagem para o segundo turno, como adversário de Crivella, de um candidato do PSOL - tudo isso contribuiu para debelar a tradicional rejeição a um candidato pentecostal em segundo turno. Quão significativo esse breakthrough eleitoral será no engajamento político pentecostal como um todo, só o tempo dirá.

Recebido em: 07/08/2017 Aprovado em: 07/08/2017 


\section{MODUS OPERANDI POLÍTICO DE EVANGÉLICOS E CATÓLICOS: CONSOLIDAÇÓES E INFLEXÓES}

\section{Brenda Carranza ${ }^{1}$}

Resumo: Sustento a hipótese de que nas últimas décadas consolidou-se o modus operandi político dos evangélicos que impulsiona uma inflexão no histórico estilo de operar na esfera política da Igreja Católica. Se tal guinada no catolicismo não é um efeito mecânico de espelhamento, no mínimo constitui-se numa forte referência para o ativismo político católico e as militâncias de seus religiosos políticos nas casas legislativas do Brasil. A argumentação apóia-se na análise dos dados trazidos por Erico Tavares de Carvalho Junior e Ari Pedro Oro, no texto "Eleiçóes municipais 2016: religião e política nas capitais brasileiras", na literatura especializada e em pesquisa empírica realizada junto às lideranças católicas carismáticas.

Palavras-chave: Política; Catolicismo; Pentecostalismo; Ativismo político; Religiosos políticos.

Abstract: I support the hypothesis that in the last decades the modus operandi of the evangelicals has been consolidated that propels an inflection in the historical style of operating in the political sphere of the catholic church. If such a turn in Catholicism is not a mechanical effect of mirroring, it is at least a strong reference for Catholic political activism and the militancy of its political religious in the legislative houses of Brazil. The argument is based on the analysis of the data brought by Erico Tavares de Carvalho Junior and Ari Pedro Oro, in the text "Municipal elections 2016: religion and politics in Brazilian capitals", specialized literature and empirical research carried out with charismatic Catholic leaders.

Keywords: Politics; Catholicism; Pentecostalism; Political Activism; Religious Politicians.

1 Professora da Pontifícia Universidade Católica de Campinas. Contato: brenda_poveda@ terra.com.br 


\section{QUESTÓES INICIAIS}

A partir da leitura do texto "Eleiçôes municipais 2016: religião e política nas capitais brasileiras", de Erico Tavares de Carvalho Junior e Ari Pedro Oro, senti-me tentada a retomar um outro artigo, publicado exatos dez anos antes. Nesse, Ari Pedro Oro e Rosilene Schoenfelder (2006) faziam sua análise sobre as eleiçôes de 2006, com foco no Rio Grande do Sul. Já no título eles incluíram a pergunta: o que há de novo? Passou-se uma década, muita água correu debaixo da ponte política do Brasil, realizaram-se duas reeleiçôes petistas à presidência da República, inclusive o impeachment dessa última, a operação Lava-Jato desmantelou mais uma torrente de escândalos de corrupção. Evangélicos e católicos enquanto atores religiosos na política estabeleceram alianças e impuseram sua pauta moral nas eleições de 2010 e de 2014.

Diante disso, perguntei-me: como o ativismo religioso (Mariano, 2006) consolidou-se? Houve alguma mudança substantiva dez anos depois? E entre os políticos religiosos (Oro; Schoenfelder, 2006), a quantas andam suas estratégias eleitorais? Do lado dos evangélicos, as candidaturas oficiais das instituiçóes ou candidatos das membresias continuam a ser mecanismos certeiros de eleição? E do lado católico quais iniciativas se espelham no ativismo evangélico? Teve alguma inflexão significativa? Para alavancar pretensôes políticas os candidatos não religiosos ainda buscam e encontram significativo apoio nas lideranças e instituiçóes religiosas?

Respostas que em seu conjunto ajudam a perfilar a maneira como os segmentos religiosos agem para alcançar as instâncias de poder, negociam representaçôes partidárias, ampliam a presença de suas lideranças religiosas ou representantes leigos no pleito eleitoral, traçam estratégias para participar na vida partidária, aprimoram o sucesso nas urnas, utilizam critérios de coaliçóes partidárias, desenham táticas nas disputas eleitorais, interagem com outras militâncias políticas, constituem modelos corporativos de representação. Dito em latim: desenvolvem seu modus operandi na esfera política. 
Esse modus operandi terá finalidades diversas em cada grupo religioso. No caso evangélico, sobretudo (neo)pentecostal, de acordo com Machado e Burity (2014, p. 206), o horizonte é sair, de um lado, da condição de minoria e subalternidade cultural, diante do apoliticismo em que ficou recluso e, de outro lado, da invisibilidade para reclamar o acesso à esfera pública. No caso da Igreja Católica implica, entre outros motivos, seu reposicionamento de diálogo igreja-Estado, perante a ascensão dos evangélicos como atores políticos que disputam, a quase naturalizada, hegemonia do catolicismo de pautar a vida pessoal e coletiva nos valores de uma ética intramundana. Ética que inclui estabelecer limites estatais em temas como paticipação política, educação, relaçóes familiares e moralidade sexual, para os quais a instituição eclesiástica não só tem posicionamentos doutrinais claros, mas almeja que a sociedade como um todo os assuma como próprios (Esquivel, 2013, p. 414).

A partir dos dados fornecidos pelo texto "Eleiçóes municipais 2016: religião e política nas capitais brasileiras" estruturo em duas partes meus comentários. Na primeira, sistematizo as tendências que consolidam o que considero um modus operandi político evangélico. Na segunda parte, apresento quatro frentes de ativismo católico que mostram as inflexóes no modus operandi político da Igreja Católica. Finalmente, faço uma breve consideração sobre o espelhamento do modus operandi católico no estilo evangélico e uma sugestão a título de aprofundamento em pesquisas qualitativas que explorem o caudaloso e cuidadoso feixe de dados apresentados pelos autores, pois sem dúvida os desdobramentos da análise do material ultrapassam as contextualizadas eleiçóes de $2016^{2}$.

2 Agradeço ao Núcleo de Estudos da Religião a oportunidade de participar como comentarista desse texto, pois sua leitura obrigou-me a sistematizar algumas ideias cuja necessária formulação eu sempre adiava. 


\section{MODUS OPERANDI EVANGÉLICO: CONSOLIDAÇÃO DE TENDÊNCIAS}

À medida que avança a leitura sobre os dados e as reflexóes das eleições municipais de 2016, nas 26 capitais brasileiras, percebemos alguns elementos que persistem no modus operandi político do setor evangélico. Tudo indica que esses elementos tendem a se consolidar, não apenas por sua recorrência nos pleitos eleitorais, mas também porque acompanham o fenômeno da participação política dos evangélicos, que, para dilatar seu poder religioso, ingressam maciçamente na esfera pública. Podemos identificar tais elementos em três tendências.

A primeira se refere aos religiosos políticos que, na categorização de Oro (2003), ${ }^{3}$ são sujeitos que explicitam sua pertença religiosa e vinculação institucional ao assumirem candidaturas e cargos na esfera pública. Esses agentes passam a instrumentalizar o capital político que sua vinculaçáo religiosa pode render $^{4}$ junto à igreja de origem, que tende a ser a primeira base eleitoral do candidato, pois "irmão vota em irmáo". Se bem que, segundo Machado (2006, p. 64), o uso político da identidade religiosa é diferenciado entre candidatos, visto que pode ser acionado apenas em eventos evangélicos e náo para os eleitores em geral'5.

Quando comparado o desempenho desses políticos religiosos nos anos 2006 e 2016, notamos que uma década atrás, segundo Oro e Schoenfelder (2006, p. 10), a presença de candidatos pentecostais era maior do que a dos evangélicos históricos. Nas observaçôes de Carvalho Junior e Oro, nas eleiçóes municipais e estaduais de 2016, a primazia de candidatos religiosos pentecostais mantém-se, como em 2006, destacando-se que a precedência

3 Ver também: Oro e Shoenfelder (2006); Oro e Mariano (2010).

4 Lembro entre os políticos religiosos com projeção nacional Marcelo Crivella (PRB), bispo afastado da IURD, Prefeito eleito do Rio de Janeiro (2016), Anthony Garotinho e sua esposa Rosinha Garotinho, ambos do PR, com fortes referências evangélicas e pertenças difusas e Marina Silva (REDE), da Igreja Bíblica da Graça.

5 A autora refere-se a Benedita da Silva (PT) da AD. 
continua a ser da Assembleia de Deus - AD, (32\%) e da Igreja Universal do Reino de Deus - IURD, (22\%). ${ }^{6}$ Evidencia-se, também, que a instrumentalização da identidade religiosa, para obter cargos nos organismos legislativos de 2016, tende a ser um dado consolidado, realidade presente no desenvolvimento histórico da participação política pentecostal com seus embates, performances e ganhos, como a literatura especializada mostra ${ }^{7}$.

Outro dado retrospectivo do cenário eleitoral, do ano de 2006, será a diversificação interdenominacional dos políticos religiosos, sejam eles representantes oficiais das denominaçóes, seja por iniciativa da membresia, em ambos os casos com inserção pluripartidária e apoio institucional (Oro; Schoenfelder, 2006, p. 24). De acordo com Carvalho Junior e Oro, tal diversificação persiste nas eleiçóes de 2016 e acrescentam como esses políticos religiosos se alocam nos partidos denominados cristãos, por defenderem valores do cristianismo. $\mathrm{O}$ escopo partidário nos quais os candidatos religiosos figuram incluem: Partido Social Cristão (PSC), Partido Republicano Brasileiro (PRB) - fundado e controlado pela IURD -, Partido Republicano (PR), Partido Trabalhista Cristão (PTC) e Partido Social Democrático Cristão (PSDC), todos alinhados no espectro ideológico à direita.

Tanto a diversificação denominacional quanto o alinhamento ideológico são dados mensuráveis que soldam a orientação política do segmento evangélico, a tempo que engrossam a crescente "onda conservadora”. Nessa onda os políticos religiosos, segundo Almeida (2017, p. 78), "fazem parte desse movimento mais amplo, sendo constituintes e constituídos por ela. [Mas nem] todos os evangélicos são conservadores, assim como a pauta conservadora vai além dos evangélicos conservadores".

6 Os autores ponderam que a capacidade eleitoral dos evangélicos está diretamente associada a sua presença proporcional em cada Regiáo; quanto menor representatividade evangélica, menos eleitos. Também destacam a correlação social dos eleitores da IURD, camada empobrecida, e o fator regional para a $\mathrm{AD}$, o Nordeste.

7 Burity e Machado (2006); Corten, Dorzon e Oro (2003); Machado e Burity (2014); Mariano (2005); Natividade (2016); Oro e Mariano (2010); Vital e Lopes (2012). 
De outro lado, os religiosos políticos representam a capilarização das instituiçóes às quais estão filiados, a tempo que são sua expressão pública nos embates eleitorais. Por isso, o desempenho desses agentes será o termômetro que mede a temperatura da eficácia estratégica institucional no propósito de construir canais políticos que os comuniquem com as instâncias de poder. Entretanto, esses representantes nem sempre se conduzem como seu eleitorado espera e à altura ética que as instituiçôes pregam. Cabe lembrar que o envolvimento dos candidatos religiosos em celeumas de corrupção e a sua punição nas urnas, com a não reeleição ou eleição, atinge a reserva moral que outrora os fez ganhar respeitabilidade social e os sustentou perante os rebanhos inflamados pelo orgulho moral de ter "homens de Deus saneando o mal da política" (Mariano; Hoff; Dantas, 2006, p. 73).

Porém, se os inúmeros escândalos desencantam e produzem uma "ressaca moral" (Mariano; Hoff; Dantas, 2006, p. 20), e dificultam os projetos expansionistas que visam a credibilidade junto à opiniáo pública nacional (Machado, 2006, p. 162), não impede a reapresentação das candidaturas nem o afastamento temporário dos religiosos políticos. Basta relembrar o caso da super faturação de ambulâncias por uma máfia que incluia 28 parlamentares evangélicos em 2006. Esse escândalo de corrupção, conhecido como sanguessugas, teve seu impacto direto com a diminuição da bancada evangélica no Congresso Nacional, nas eleiçôes de 2006, passando de 60 a 15 membros $^{8}$. Mesmo sendo indiciado como responsável de liderar o esquema sanguessuga Magno Malta, pastor da Igreja Batista e cantor gospel (PR), foi reeleito senador pelo Estado do Espírito Santo em 2010.

A reapresentação dessa candidatura encontra, entre outras, sua explicação pela existência de mecanismos teológicos que, disparados por bispos e pastores, se constituem em arranjos discursivos que permitem a regeneração

8 Disponível em: <https://oglobo.globo.com/brasil/eleicoes-2006/quase-30-dos-deputadosenvolvidos-com-sanguessugas-desistem-da-reeleicao-5006189>. Acesso em: 2 set. 2017.

9 Disponível em: <https://www25.senado.leg.br/web/senadores/senador/-/perfil/631>. Acesso em: 2 set. 2017. 
dos "pecadores" que "sucumbiram ao mal", pois "a tentação do poder é grande e a carne fraca", consequentemente, os homens de Deus "não suportaram as forças do mal". Verbalização que nos fiéis ecoa pela percepção negativa que tem da política, encontrando ressonância ao terem internalizado o mal como componente estrutural da esfera pública. Por isso, na lógica da freguesia religiosa, a arena política pode ser desvirtuada e desvirtuar os religiosos políticos (Tadvald, 2006, p. 80). Mais ainda, é a certeza da superioridade ética que, alicerçada nas premissas religiosas de contarem com a força divina, faz com que os grupos religiosos se recomponham internamente no meio da avalanche de denúncias e continuem a apostar em seus representantes.

O discurso teológico triunfalista, dos anos noventa, que permitiu empoderar ideologicamente os grupos religiosos na tentativa de tomar posse dos postos de comando no país, desloca-se para um discurso teológico de humildade penitente. Tais acomodaçóes ideológicas, quer triunfalista quer de humildade, tem ressonâncias diferentes. Para as cúpulas das instituiçóes religiosas tornam-se um "lubrificante" que perpetua a legitimidade de continuar na lida política, não só com as fraquezas, mas apesar delas. Já para as membresias, enquanto comunidades fortalecidas na fé, significa impulsionar a esperança de gerar membros que representam certa "novidade" para fazer a "diferença" na política brasileira.

A segunda tendência, a localizamos no ativismo religioso, que Mariano $(2005)^{10}$ caracteriza como sendo uma atuaçáo orquestrada das instituiçóes/ igrejas evangélicas para a cooptação do apoio das lideranças eclesiásticas, representação partidária, nomeação de candidatos próprios, coligaçóes partidárias e o desenvolvimento de uma máquina narrativa, marcada pela

${ }^{10}$ No texto "Pentecostais e Política no Brasil”, Ricardo Mariano (2005) traça uma periodização desse ativismo político pentecostal. Fraccionado por décadas é possível acompanhar a genealogia e os motivos das igrejas que vão ingressando na esfera política, o perfil dos religiosos políticos e o processo do cortejo ideológico pelos grupos evangélicos. Ver também: Mariano, Hoff e Dantas (2006); Oro e Mariano (2010). 
síndrome persecutória e a Teologia da Prosperidade ${ }^{11}$, que transforma o rebanho evangélico em rebanho eleitoral. Esse último se explica, segundo Simone Bohn (2004 apud Mariano; Hoff; Dantas, 2006), por serem os fiéis uma clientela eleitoral mais exposta à autoridade dos dirigentes eclesiásticos, transferindo-se a autoridade pastoral à autoridade política, e por sua assídua assistência à igreja.

Rastreamos traços desse ativismo político nas tabelas da eleição a vereadores em 2016, nas quais percebemos que o número de candidatos evangélicos é quatro vezes maior do que os católicos. De um lado, nota-se que os resultados das urnas deve-se à forte capilarização dos políticos religiosos espalhados em todas as capitais, independetemente de sua performance eleitoral, como veremos mais adiante. Do outro lado, corroboram a eficácia, relativa, das estratégias de mobilização, coligaçóes e da teologia ad hoc do ativismo religioso. Assim, o investimento das instituiçóes nas candidaturas oficiais e nas filiações partidárias que garantem a intervenção parlamentar, está mais do que consolidado.

Como é sabido, para o ativismo político é essencial o exercício da pressão política que garanta a defesa de interesses corporativos, a intervençáo nas votaçóes de políticas públicas e a salvaguarda da estrita moralidade cristã - possibilitando erguer trincheiras contra discussóes e/ou políticas públicas que envolvam a discriminalização do aborto, os direitos reprodutivos, orientação e diversidade sexual, casamento igualitário, ideologia de gênero (Vital; Lopes, 2012; Natividade, 2016). Para tal, os representantes evangélicos se organizam municipal, estadual e federalmente em bancadas e frentes parlamentares nas casas legislativas, utilizando-se dos mesmos recursos disponíveis na política brasileira.

${ }^{11}$ Na visão de Machado e Burity, a "Teologia da Prosperidade promoveu um deslocamento das expectativas milenaristas de salvação para uma vida de graças no presente, favorecendo a inserção dos pentecostais na política” (2014, p. 604). Já a síndrome persecutória caracterizada pelo medo, temor, risco, perigo, perseguiçáo, sofrimento etc, acompanha e atualiza as bandeiras que justificam a inserção religiosa na política das igrejas, ora erguendo como inimigo a Igreja Católica, ora o PT (Mariano, 2005, p. 2). 
O resultado será uma maior visibilidade coletiva, o fortalecimento que aufere benefícios para parlamentares religiosos e suas igrejas, como a concessão de emissoras de rádio e televisão, e a conquista na reinvidicação de projetos de interesse das instituiçôes religiosas. Exemplo dessa eficácia organizacional está no trabalho realizado pela Frente Parlamentar Evangélica no Congresso Nacional que conseguiu a sanção da lei de No 10.825 , que garante total liberdade de culto no país, e a sanção do presidente Lula ao Código Civil, que mudou a personalidade jurídica das organizaçóes religiosas.

Nos dados das eleiçóes de 2016, para vereadores em Porto Alegre, Carvalho Junior e Oro mencionam a constituição, ainda que informal, de uma bancada religiosa, sobretudo cristá. Assim, também, mencionam um grupo de vereadores católicos, fundado em 2002, na Arquidiocese de Porto Alegre, sob a qual todos os candidatos eleitos formam parte. Ambos os registros (bancada e grupos) atualizam a incisiva tendência organizativa como traço estrutural e estruturante do ativismo político evangélico. Mas tudo indica que se estende, cada vez mais, ao catolicismo como modo de fazer política, o que logo veremos.

De outra parte, o reconhecido potencial eleitoral dos segmentos religiosos os tornam uma referência política que consolida a terceira tendência desse modus operandi evangélico. Daí que a procura de apoio de lideranças laicas turbina seu capital político, ancorado na capacidade de mobilização eleitoral junto à membresia e as lideranças eclesiásticas, oferecendo uma ampla margem de poder de barganha nas negociaçóes partidárias. Fortalecimento que, a cada eleição, faz com que os grupos evangélicos sejam contemplados como forças indispensáveis nos pleitos eleitorais e até temida a sua não inclusão. Prova contundente desse peso religioso foram as eleiçóes majoritárias de 2010, quando os candidatos à presidência tiveram que desenvolver estratégias eleitorais para minimizar a rejeição por motivos religiosos e 
negociar diretamente "acordos" e concessóes sobre posicionamentos morais que pautaram o pleito (Oro; Mariano, 2010, p. 24-31) ${ }^{12}$.

A partir das tabelas elaboradas por Carvalho Junior e Oro identificamos as estratégias acionadas pelos candidatos laicos ao executivo para se aproximarem aos segmentos evangélicos. Vejamos os dados.

No quesito participação em eventos religiosos encontramos os candidatos Pedro Paulo Carvalho (PMDB) do RJ, frequentando cultos da AD Madureira, Vitória em Cristo e da Igreja Mundial do Poder de Deus; o prefeito reeleito Rui Palmeira (PSDB) de Maceió/AL, em eventos da AD. Os reeleitos teceram na gestão anterior uma teia de avizinhamento com os evangélicios como Carlos Eduardo (PDT) de Natal/RN, que chegou a realizar culto de Ação de Graças (equivalente ao Te Deum católico); Zenaldo Coutinho (PSDB) Belém/PA durante todo o mandato participou de eventos evangélicos e Marcus Alexandre (PT) Rio Branco/AC, alinhou-se no mandato anterior com a maior denominação do Acre, Igreja Batista do Bosque, recebendo o apoio na eleição. Ao passo que o prefeito eleito João Dória em SP (PSDB), propôs uma parceria com entidades evangélicas e Emanuel Pinheiro (PMDB) de Cuiabá/MT garantiu apoiar a Igreja Batista e AD.

No maior evento evangélico a Marcha de Jesus, constituído jurídica e simbolicamente em Dia Nacional da Marcha ${ }^{13}$, destacam-se por sua participação Antônio Carlos Magalhães Neto (DEM-Democratas) de Salvador/ BA e o reeleito Roberto Cláudio (PDT) de Fortaleza/CE; Firmino Filho (PSDB) de Teresina/PI; eleito por segunda vez, Edvaldo Nogueira (PC do B) de Aracaju/SE, e no seu histórico consta o apoio aos shows gospel.

12 Os autores fazem uma etnografia de como os candidatos Marina Silva (REDE), José Serra (PSDB), Dilma Rousseff (PT) tiveram que cortejar os setores evangélicos e grupos católicos. No primeiro turno a candidata petista firmou propósitos de seu eventual governo não retomar a discussão temas polêmicos da pauta familiar e sexual.

${ }^{13}$ Lei No12.025, de 3.set. 2009 cujo Art. $1^{\circ}$ reza: É instituído o Dia Nacional da Marcha para Jesus, a ser comemorado, anualmente, no primeiro sábado subsequente aos 60 (sessenta) dias após o Domingo de Páscoa. Disponível em: <htpp//www.planalto.gov.br/ ccivil_03/_Ato2007-2010/2009/Lei/L12025.htm>. Acesso em: 12 out. 2017. 
Registramos na composição das chapas a integração como vice-prefeitos(as) 2 pastores, 2 pastoras e 2 membros de igrejas. São eles: Rodrigo Pacheco (PMDB) em BH/MG, pastor da Igreja Batista Lagoinha; Edvaldo Nogueira (PC do B) de Aracaju/SE, pastor da AD; Lauro Davi (PROS) de Campo Grande/MS, pastora da Igreja Missionária em Cristo; Sandró Baré (PP) de Boa Vista/RR, pastora da AD e Adriana Acorcci (PT) em Goiânia/ GO membro da AD e Jorge Bernardi (REDE), em Curitiba, membro da Igreja Presbiteriana.

Contaram com o apoio de partidos cristáos os dois candidatos do Recife: Geraldo Júlio (PSB) e João Paulo (PT), os candidatos de Porto Velho/RO Dr. Hilton de Lima (PSDB) e Léo Moraes (PTB), os dois candidatos de Florianópolis Gean Loureiro (PMDB) E Ângela Amin (PP) e Sebastião Melo (PMDB) de Porto Alegre.

Já Luciano Rezende (PPS) em Vitória/ES, obteve o apoio do senador Magno Malta (PR-ES), enquanto Clécio Luís (REDE) de Macapá/AP, ganha no setor evangélico um aliado. Enivaldo Holanda Júnior (PDT) de São Luís/MA e Luciano Cartaxo (PSD) de João Pessoa/PB conseguiram a declaração formal de apoio da $\mathrm{AD}$, que incentivou a votar nos "irmãos". Também recebeu amplo apoio da AD Rafael Grecca (PMN).

Angariaram suporte de organizaçóes religiosas Carlos Henrique Amastha (PSB) de Palmas/TO Convenção de Igrejas e Ministros das Assembleias de Deus, Missão no Tocantins (COIMADETINS) e Maria Teresa Saenz (PMDB) de Boa Vista/RR, Ordem de Ministros Evangélicos de Roraima (OMER). O releito Arthur Neto (PSDB) de Manaus/AM contou com o apoio explícito do fundador de uma das Igrejas neopentecostais de maior expressão da cidade, o Ministério Internacional da Restauração.

Todas as frentes de aproximação são cobertas: apoio partidário, declaração de igrejas e organizaçóes religiosas e o envolvimento explícito de lideranças eclesiásticas. A frente ecumênica, ao alinhar candidatos laicos frente ao público evangélico (assistir a cultos) reforçando um imaginário de respeito religioso, independente de ser ou não crente o candidato. A frente que baliza a presença pública das manifestaçóes religiosas evangélicas 
(Marcha de Jesus, shows gospel), outrora reservadas às procissōes católicas. A frente que valida a participação confessional na esfera partidária ora com candidatos nas chapas as prefeituras, ora os apoios dos partidos cristáos e das organizaçóes evangélicas. É nítido o percurso que recorrem os políticos não religiosos na procura de fortalecer suas candidaturas e na obtenção de garantias de apoio dos grupos religiosos.

Não resta a menor dúvida que os dados das eleiçóes a cargos executivos e legislativos municipais em 2016 atualizam a afirmaçáo de que, na última década, não existe eleição em que o ativismo político evangélico deixe de ser acionado. É possível visualizar os agentes e os religiosos políticos reagirem na disputa como uma extensa rede de neurotransmissores espraiados ao longo do embate eleitoral. Por essa laboriosidade os evangélicos, sobretudo pelo engajamento dos pentecostais, granjearam o reconhecimento que os tornou uma referência e garantiram seu espaço no sistema político, em especial no Legislativo.

Porém, mesmo que todo esse processo desague na consolidaçáo de tendências no modus operandi político, acompanhando a expansão evangélica, e possa parecer robusto na esfera política, de acordo com Machado e Burity (2014, p. 602), esse grupo religioso "é minoritário e se sente discriminado na sociedade civil e no sistema político brasileiro".

Se o segmento evangélico, minoritário demograficamente e no sistema político, consolida nos últimos tempos em três tendências seu modus operandi político, qual seria a novidade da maioria demográfica religiosa, historicamente parte do sistema político, no seu modus operandi político? Nos adentramos, na segunda parte deste comentário para focalizar os católicos carismáticos e conservadores. 


\section{NOVIDADE NO MODUS OPERANDI POLÍTICO DA IGREJA CATÓLICA}

No ano de 2006, Oro e Schoenfelder (2006, p. 10) afirmaram que o número de católicos na disputa eleitoral a cargos eletivos era baixo, sinalizando alguns motivos, entre eles a posição assumida da Igreja Católica no Brasil de não participar diretamente do político institucional, desaconselhando candidaturas do clero. Dez anos depois, Carvalho Junior e Oro apontam o aumento dos religiosos políticos católicos e seu perfil conservador. A partir das tabelas disponibilizadas pelos autores foi possível elaborar o seguinte quadro que lastreia comparativamente como evangélicos e católicos concorreram nas capitais e os resultados da sua performance eleitoral.

Quadro 1 - Candidatos e eleitos às câmaras de vereadores das capitais brasileiras, eleiçóes 2016

\begin{tabular}{|c|c|c|c|c|}
\hline Cidade & $\begin{array}{c}\text { Candidatos } \\
\text { Evangélicos }\end{array}$ & $\begin{array}{c}\text { Eleitos } \\
\text { Evangélicos }\end{array}$ & $\begin{array}{c}\text { Candidatos } \\
\text { Católicos }\end{array}$ & $\begin{array}{c}\text { Eleitos } \\
\text { Católicos }\end{array}$ \\
\hline 1. Porto Alegre/RS & 16 & 5 & 11 & 8 \\
\hline 2. Curitiba/PR & Não registrado & 8 & Não registrado & 18 \\
\hline 3. Florianópolis/SC & 5 & 1 & 1 & Não eleito \\
\hline 4. Rio de Janeiro/RJ & 26 & 9 & 17 & 9 \\
\hline 5. São Paulo/SP & 36 & 17 & 10 & 7 \\
\hline $\begin{array}{c}\text { 6. Belo Horizonte/ } \\
\text { MG }\end{array}$ & 46 & 13 & 11 & 8 \\
\hline 7. Vitória/ES & 11 & 3 & 3 & 2 \\
\hline 8. Goiânia/GO & 21 & 5 & 7 & 5 \\
\hline $\begin{array}{c}\text { 9. Campo Grande/ } \\
\text { MTS }\end{array}$ & 19 & 6 & 5 & 4 \\
\hline 10. Cuiabá/MT & 12 & 4 & 3 & 3 \\
\hline 11. Salvador/BA & 43 & 8 & 4 & 4 \\
\hline 12. Fortaleza/CE & 21 & 5 & 5 & 4 \\
\hline 13. Recife/PE & 49 & 10 & 1 & 1 \\
\hline
\end{tabular}


Quadro 1- Candidatos e eleitos às câmaras de vereadores das capitais brasileiras, eleiçóes 2016

\begin{tabular}{|c|c|c|c|c|}
\hline Cidade & $\begin{array}{l}\text { Candidatos } \\
\text { Evangélicos }\end{array}$ & $\begin{array}{c}\text { Eleitos } \\
\text { Evangélicos }\end{array}$ & $\begin{array}{c}\text { Candidatos } \\
\text { Católicos }\end{array}$ & $\begin{array}{c}\text { Eleitos } \\
\text { Católicos }\end{array}$ \\
\hline 14. São Luís/MA & 21 & 4 & Náo registrado & 5 \\
\hline 15. Teresina/PI & 16 & 3 & 7 & 5 \\
\hline 16. Aracaju/SE & 18 & 2 & 3 & 1 \\
\hline 17. Maceió/AL & 9 & 1 & 6 & 6 \\
\hline 18. João Pessoa/PB & 18 & 6 & Não registrado & 5 \\
\hline 19. Natal/RN & 16 & 3 & 12 & 8 \\
\hline 20. Manaus/AM & 45 & 14 & 7 & 6 \\
\hline 21. Belém/PA & 29 & 6 & 3 & 3 \\
\hline 22. Palmas/TO & 23 & 7 & 3 & 2 \\
\hline 23. Macapá/AP & Não registrado & 3 & Não registrado & 1 \\
\hline $\begin{array}{l}\text { 24. Porto Velho/ } \\
\text { RO }\end{array}$ & 15 & 5 & 1 & 1 \\
\hline 25. Boa Vista/RR & Náo registrado & 3 & Náo registrado & 1 \\
\hline 26. Rio Branco/AC & Não registrado & 4 & Não registrado & 1 \\
\hline Totais & 515 & 155 & 130 & 118 \\
\hline
\end{tabular}

Fonte: CARVALHO JUNIOR, Erico Tavares de; ORO, Ari Pedro. Eleiçôes municipais 2016: religiáo e política nas capitais brasileiras. Debates do NER, Porto Alegre, ano 18, n. 32, 2017.

Quando comparamos os evangélicos com os católicos, dos 515 candidatos evangélicos, são eleitos 155 e dos 130 católicos são eleitos 118. Como se disse páginas atrás, a capilaridade evangélica quantificada em número de candidatos (515) é maior que o número dos candidatos católicos (130). Entretanto, se comparadas proporcionalmente a performance eleitoral dos católicos é melhor, pois de 130 que comparecem ao pleito elegem-se 118, já os evangélicos colocam na disputa 515 elegendo apenas 155 , consequentemente, o segmento católico tende a ser mais eficaz nos resultados.

Sobre esse saldo positivo na performance eleitoral católica, chamou a minha atenção duas coisas. Uma, quando analisadas as eleiçóes em Porto Alegre, Carvalho Junior e Oro informam sobre a organização católica a qual 
pertencem os candidatos. Assim, candidatam-se 11 vereadores católicos, 8 foram eleitos e desses eleitos 7 fazem parte de um Grupo de Vereadores Católicos, fundado na Arquidiocese em 2002. Outra coisa: 130 são os candidatos católicos, no entanto, o número de religiosos políticos em formação nos últimos anos é bem maior, como apresentaremos adiante.

O "sucesso" eleitoral católico apoiado na confessionalidade dos religiosos políticos e sua organização tem contribuído para uma inflexão no modus operandi político católico no qual vocacionar membros do laicato e incentivar sua organização representativa tem adquirido diversas formas. Concentro especificamente minha análise nas candidaturas apoiadas pela Renovação Carismática Católica (RCC), face da pentecostalização cristã dentro da Igreja e alinhanda a sua ala conservadora. Como tenho abordado em outros textos (Carranza, 2009, 2011, 2015; Carranza; Mariz, 2016), a RCC converteu-se, no início do século XXI, no modelo hegemônico na igreja, quer seja na espiritualidade quer seja na pastoral, e agora soma-se seu ativismo político. ${ }^{14}$ Não pretendo fazer uma transposição mecânica das categorias ativismo político e religiosos políticos, advindas do segmento evangélico como dissecadas páginas atrás, entretanto, as utilizo aqui como referência para visualizar o possível espelhamento das mesmas no modus operandi político católico.

Começo com a constatação dos carismáticos reconhecerem a perda de hegemonia política do catolicismo que, segundo eles, se instala na assimetria trazida no poder eleitoral pentecostal evangélico e seu estilo corporativo na persecução dos próprios interesses ${ }^{15}$. Para o Presidente da RCC as lideranças

${ }^{14}$ Lembro as outras fases do ativismo católico conservador no século passado a começar pela Liga Eleitoral Católica de 1930, logo nos anos de 1970 se recompóe em torno da lei do divórcio, com o Concilio Vaticano II e a Teologia da Libertação teremos um breve giro progressista, ressurgindo novamente nos anos de 1990, com o catolicismo midiático-carismático (Carranza, 2011).

15 Os dados empíricos contidos neste texto formam parte do acervo do Centro de Estudos do Pentecostalismo Latino-americano, projeto de pesquisa (2010-2012) coordenado por Paul Freston, Maria das Dores Campos Machado e Cecília Mariz e financiado 
religiosas pentecostais "são extremamente clientelistas [...] elas vão [ao Congresso Nacional] para defender interesses muito particulares de igrejas, para se estabelecer na mídia e obter as concessões de canais de tv [...] espaços que só através de uma política clientelista você consegue. ${ }^{16}$ Conhecedores desse ativismo político evangélico, os carismáticos e os políticos religiosos conservadores intensificam seu próprio ativismo aumentando sua presença nas Câmaras Municipais e Assembleias Legislativas (Machado, 2015, p. 46). Por trás desses resultados observamos quatro "frentes" desenvolvidas simultaneamente nos últimos dez anos, todas como braços extensivos da Igreja Católica na esfera política que se propóem concretizar os ensinamentos da Doutrina Social da Igreja. ${ }^{17}$ Três dessas frentes influenciadas pela capilarização do pentecostalismo católico presente nas 275 dioceses e circunscrições católicas brasileiras.

A primeira frente é impulsionada pelo Ministério Fé e Política (MFP) que operacionaliza as diretrizes de inserção partidária formuladas pela RCC. Para isso, o MFP tem as seguintes atribuiçóes: articular as coordenaçóes diocesanas e estaduais; identificar as potenciais lideranças capazes de se transformar em candidatos (sob a premissa de vocação missionária para atuar na política partidária); mediar disputas internas entre candidatos, ajudar na nomeação dos candidatos para concentrar a plataforma eleitoral carismática; apoiar candidaturas e colaborar com a organização de eventos regionais, estaduais e nacionais, além de promover encontros anuais com os mandatários e seus assessores.

Durante as campanhas eleitorais, o MFP zela para que a identidade religiosa e filiação institucional seja explícita e que os conteúdos da propa-

pela Templeton Fundation/Pentecostal and Charismatic Research Initiative (PCRI) da University of Southern California, no qual atuei como pesquisadora. As informaçóes serão identificadas: Acervo PCRI, Entrevista n., iniciais dos informantes, mês, ano.

${ }^{16}$ Acervo PCRI, Entrevista n. 10, M.V., set. 2011.

${ }^{17}$ Corresponde ao corpo doutrinal que articula a intepretação moral e histórica da Igreja Católica sobre os acontecimentos, propondo os princípios de reflexão, critérios de juízo de valor e orientaçóes de ação para todos seus membros. 
ganda incluam as bandeiras defendidas pela RCC e a hierarquia católica. Isto é, posicionar-se contra: o aborto, liberação das drogas, casamento igualitário, direitos reprodutivos, ideologia de gênero. É responsabilidade do MFP conscientizar para a ação política e orientar processos sistemáticos de formação dos membros carismáticos, mediante a elaboração de cartilhas, palestras e cursos. No entanto, a heterogeneidade do Movimento Carismático mostra que nem todos os candidatos oficiais, nem todas as coordenaçóes e os grupos de oração, concordam com os procedimentos assumidos pelo MFP, quando não manifestam seu descontentamento pelos os religiosos políticos que só aparecerem nos grupos e eventos em época eleitoral (Freitas, 2016, p. 132). ${ }^{18}$

Em que pese o empenho de formar políticos religiosos vocacionados para a vida política, nem sempre o modo de inserção partidária é o mais condizente com os mecanismos democráticos, chegando às raias da jocosidade. Caso vivenciado pela vice-prefeita de uma cidade no interior de São Paulo que narra como, após receber uma revelação divina, escolheu por meio de um sorteio santo o partido político para disputar candidatura no pleito eleitoral. Ela conta que, com o marido, que já tinha sido prefeito por outra legenda partidária na mesma cidade, "colocamos todos os nomes dos partidos em papeizinhos. Rezamos. Perguntamos: o Senhor em que partido me quer? Pensamos: se sair duas vezes o mesmo papelzinho o Senhor me quer nesse partido" ${ }^{19}$. O Senhor escolheu o partido, ela candidatou-se, venceu a eleição, assumiu o cargo, agradeceu o apoio dos grupos de oração da cidade que votaram nela e o marido virou assessor de seu gabinete.

Anedota à parte, a participação político-partidária de caráter confessional traz algumas características semelhantes do ativismo evangélico, descritas

${ }^{18}$ Freitas registra as posiçôes da coordenação estadual de Rio de Janeiro que discorda da participação oficial em política da RCC, a da coordenação de Macapá que considera o campo da política demoníaco, portanto, não se envolve com ela (Freitas, 2015, p. 144-147).

${ }^{19}$ Acervo PCRI, Entrevista n. 7, S. P., set. 2011. 
anteriormente, enfatizando, no caso católico, a interlocução da Igreja com o Estado. Mesmo que a conversáo pessoal seja conditio sine qua non de atuação dos que representam a RCC no campo partidário, há as exigências de perícia na administração pública e, de certa maneira, pesa seu perfil que tende a ser de classe média, ensino superior completo, trabalhadores do serviço público, empresários, professores, profissionais liberais (Freitas, 2015; Machado, 2015).

Exemplo magistral dessa convergência vocacional para a política, gestão pública e perfil social encontramos no ex-seminarista Gabriel Chalita, originário de Cachoeira Paulista/SP, membro da comunidade católica Canção Nova e seu apresentador nos programas da TV Canção Nova. Com intenso transito partidário, como membro do PSDB/SP, Chalita é nomeado Secretário de Educação do Estado de Sáo Paulo (2003-2007), filiado ao PSB/SP, elegeu-se vereador por SP (2009-2012), deputado federal (PMDB/SP) no período 2011-2015, filiado ao PMDB candidatou-se, sem sucesso, para a prefeitura de São Paulo em 2012, em 2015 assume novamente, na gestão petista, a Secretaria de Educação (2015-2016), por sua vez candidata-se vice-prefeito como membro do PDT, na chapa de Fernando Hadaad, candidato a reeleição em 2016, não vence as eleiçôes. Desiludido da vida política, com diversas denúncias de corrupção e investigação criminal ${ }^{20}$ e após ser nomeado na operação Lava-Jato, Chalita abandona a carreira política e envereda carreira em Hollywood como roteirista. ${ }^{21}$

Interessa destacar aqui que, para as lideranças carismáticas ter um religioso político constitui-se numa forma de alinhamento com a agenda política da hierarquia católica e a possibilidade de usufruir do capital simbólico

${ }^{20} \mathrm{O}$ religioso político foi alvo de apuraçóes por formação de quadrilha, lavagem de dinheiro, peculato, corrupção passiva, fraude em licitação. Num outro processo é suspeito de ter recebido 50 milhóes quando estava à frente da Secretaria de Educação do Estado de São Paulo. Disponível em: <http://sao-paulo.estadao.com.br/noticias/geral,mpe-abreinvestigacao-criminal-contra-gabriel-chalita,1706271>. Acesso em: 7 out. 2017.

${ }^{21}$ Disponível em: <https://oglobo.globo.com/brasil/depois-de-mencionado-na-lava-jatochalita-tenta-carreira-em-hollywood-21050901 >. Acesso em: 2 out. 2017. 
que outorga esse reconhecimento de pertença (Carranza, 2015, p. 70-71). É também o mecanismo de manter acessos rápidos à máquina do Estado, cujos critérios que orientam a escolha partidária não são ideológicos, mas circunstanciais e pragmáticos, como entre os evangélicos, pois deve ser garantida a estrutura que vença as eleiçóes. Da parte dos partidos representa o acesso ao nicho eleitoral certo, no caso carismático católico, aumentando suas chances de assertividade nas urnas, mais tempo partidário na TV e acesso a recursos no fundo econômico partidário.

Mas, para a disputa eleitoral confessional são necessárias técnicas de marketing, profissionalização na gestão do mandato, qualificação dos assessores, competência na condução de campanhas políticas e formação na área fiscal. Arsenal estratégico necessário para os religiosos políticos carismáticos que, até 2011 não era dominado entre os 213 vereadores em exercício, 143 congressistas (federais e estaduais), nem pelos mais de 400 candidatos prestes a participar em futuras eleiçóes de 2012 (Freitas, 2011, p. 119). Sobre esse dado cabe uma observação.

Páginas atrás, vimos que foram 130 candidatos católicos que se apresentaram nas eleiçóes de 2016, segundo registrado por Carvalho Junior e Oro. No entanto, Freitas registra um elevado número de potenciais candidatos, indica 400, para essa mesma eleição. Cabe a pergunta: o que aconteceu com esses candidatos potenciais? Sendo tantos, como é que o número de católicos à disputa eleitoral não foi maior? Questôes e dados a serem pesquisados.

Retomamos a carência de formação específica dos candidatos católicos que deverá ser guarnecida. Para isso abre-se a segunda frente do ativismo político carismático com a criação, em 2009, do Instituto Thomas More. Considerado patrono dos políticos carismáticos, por ter contestado a autoridade de Henrique VIII sobre a Igreja Católica, o filósofo, diplomata, escritor e advogado inglês, Thomas More (1478-1535), canonizado como mártir em 1935, inspira o Instituto ligado ao MFP. A iniciativa surge da mobilização dos religiosos políticos carismáticos de São Paulo, pretende a formação de quadros políticos profissionais, oferece apoio financeiro para candidaturas e orienta com estratégias eleitorais. Sem sede física, funciona 
como uma instância promotora e articuladora dos processos de formação, contabilizando entre seus formados 41 vereadores eleitos nas eleições de 2012 (Freitas, 2015, p. 150).

$\mathrm{Na}$ concepção de seu mentor, o deputado federal Reginaldo Alguz (PV/ MG), o Instituto corresponde à conjuntura política porque: "precisamos unir nossos recursos como os evangélicos, pois não é a toa que eles estão na frente nas bancadas no Congresso Nacional" ${ }^{22}$. Esse instituto está sendo formado, afirma Evandro Gussi (PV/MG), assessor parlamentar de Alguz, "para ensinar a trabalhar as pessoas da RCC [...] a intenção é eleger pelo menos um representante em cada diocese" 23 .

Ainda que necessária, a proposta do Thomas More não foi bem recebida pelas outras instâncias de organização eleitoral da RCC, sobretudo quando começou a interferir nos critérios de nomeação de candidaturas oficiais, provocando a divisão interna no MFP. Disputas que frearam as intenções do Instituto de ampliar o comando nas candidaturas dos deputados federais Salvador Zimbaldi (PROS/SP) e Gabriel Chalita (então no PSDB), aos poucos o Instituto cedeu sua inspiração inicial ao Centro Nacional de Formação, promovido pela RCC na nova sede Nacional em Lorena/SP, inaugurada em setembro de 2017.

Na terceira frente do ativismo político carismático está o Encontro de Cristãos em Busca da Unidade e Santidade (ENCRISTUS), fundado em 2008 sob a liderança de representantes das Novas Comunidades Católicas, um desdobramento da RCC, e o apoio da CNBB e do $\mathrm{MFP}^{24}$. Em nome do "ecumenismo político" o ENCRISTUS nasce com o objetivo de articular

\footnotetext{
${ }^{22}$ Acervo PCRI, Entrevista n. 7, R. A., set. 2011.

${ }^{23}$ Acervo PCRI, Entrevista n. 9, C. M., set. 2011.

${ }^{24}$ A ideia original surgiu em 2003, em Buenos Aires - com o apoio do Cardeal Bergoglio (hoje Papa Francisco) -, sob o nome Comunhão Renovada entre Católicos e Evangélicos no Espírito Santo (CRECES), que reuniu milhares de pessoas, durante vários encontros anuais, no estádio Luna Park. Há outras iniciativas similares, como United in Christ (Canadá) e Kairós (Itália).
} 
parlamentares em exercício, católicos e evangélicos, para uma aproximação interdenominacional que favoreça viabilizar agendas políticas no tocante a temas comuns de defesa da moralidade cristã e intercâmbio de conhecimento sobre projetos sociais. O ENCRISTUS realizará diversos encontros de caráter nacional e a divulgação de materiais, digitais e impressos (Machado, 2015, p. 64). Entretanto, aos poucos, a proposta enveredou-se para instâncias mais estruturadas, colóquios teológicos, encontros bíblicos e intercâmbio de pregaçóes, levando à diluição da agenda política inicial ${ }^{25}$.

Até aqui tratamos das três frentes políticas promovidas pela RCC. De acordo com Procópio (2012, p. 81-81), a maneira como os carismáticos se relacionam com a política sugere três leituras: a catequético-conversionista, que coloca a ênfase na inserção partidária e nas esferas legislativas e executivas com a finalidade de transformá-las através do testemunho dos agentes religiosos. É o que identificamos no MFP. Outra leitura seria uma composição-bricolagem, advinda dos arranjos e mutaçóes que o projeto político da RCC sofre quando entra em colisão com os interesses internos e externos. Nesta análise corresponde ao Instituto Thomas More e o ENCRISTUS. A última leitura, seria perceber o caráter multiposicional que os carismáticos mantêm nas eleiçôes, "acionando representação múltipla onde elementos religiosos (defesa da igreja, da família, da vida etc.) serão somados à elementos políticos (desenvolvimento, ética, distribuição de benefícios etc.), que visem o sucesso ao final do escrutínio" (Procópio, 2012, p. 85).

A quarta e última frente do modus operandi político é a constituição da Frente Parlamentar Mista Católica Apostólica Romana (FPMCAR), lançada em 28 de maio de 2015. Inaugurada na sede da CNBB a FPMCAR foi ratificada com a tomada de posse que, segundo seu presidente o deputado federal Givaldo Carimbão (PROS/AL), "há muito atua na Câmara, porém, nunca tinha sido ratificada, pois o regimento da Casa pede uma série de

${ }^{25}$ Acervo PCRI, Entrevista n. 29, M. M., nov. 2011. 
requisitos que só agora conseguimos preencher" ${ }^{26}$. A proposta é a de ser vigilantes na Câmara para que "a lei dos homens não rasgue a lei de Deus [afirma Carimbão]. Sabemos que existe a Constituição, mas tem a Bíblia sagrada que é a lei de Deus. Nós não podemos deixar que fiquem violentando, rasgando aquilo que está na Bíblia sagrada”.

$\mathrm{O}$ argumento público do deputado Carimbão, que coloca a Bíblia como lei máxima nacional acima da Constituição, assemelha-se às posturas dos parlamentares pentecostais e contradiz o lugar "neutro" que a Constituição assume para a Igreja Católica (Vital, 2017). Isso porque não se pode colocar no mesmo registro a Bíblia e a Constituição, pois respondem a regimes distintos, um é secular e outro religioso.

A FPMCAR se ergue, segundo seu Presidente, como representação das posiçóes oficiais em matéria de doutrina e dogmas da Igreja Católica e "sem dúvida trabalharemos juntos com a Frente Parlamentar Evangélica, em determinados momentos estaremos juntos para discutirmos as questóes cristás". ${ }^{27}$ Para Carimbão, num primeiro momento a Frente não tem intençôes de desenvolver estratégias de intensificar campanhas eleitorais e de coordenar mecanismos de representaçáo para aumentar o número de religiosos políticos na Câmara, mas apenas articular açóes que garantam os interesses corporativos da Igreja nas casas legislativas. Propóe-se, também, organizar grupos de oração, encontros espirituais e um grupo de estudo para acompanhar os debates e discussōes na Câmara de projetos relacionados com a moralidade familiar e sexual. ${ }^{28}$

${ }^{26}$ Áudio gravado em entrevista. Disponível em: <http://www2.camara.leg.br/camaranoticias/ radio/materias/com-a-palavra/489102-deputados-lancam-frente-parlamentar-mistacatolica-apostolica-romana.html>. Acesso em: 12 out. 2017.

27 Áudio gravado em entrevista. Disponível em: <http://www2.camara.leg.br/camaranoticias/ radio/materias/com-a-palavra/489102-deputados-lancam-frente-parlamentar-mistacatolica-apostolica-romana.html>. Acesso em: 12 out. 2017.

${ }^{28}$ Disponível em: <http://www.prosnacamara.org.br/noticia/693/carimbao-toma-posse-nafrente-parlamentar-catolica/>. Acesso em: 28 set. 2017. 
Duzentos e quinze deputados aparecem como signatários da FPMCAR, divididos 173 parlamentares no seguinte espectro partidário: PMDB (29), PP (27), PT (25), PSDB (23), PR (15), PSB (14), PSD (13), DEM (11), PDT (8), PTB (8), os restantes 42 deputados encontram-se pulverizados em mais 15 partidos. Dentre os partidos tidos como cristãos encontramos no PRB (3), no PSC (2) e no PSC (3). Entre os deputados que integram a FPMCAR encontramos Eros Biondini (PROS/MG), cantor carismático, Flavinho (PSB/SP), membro da Cançáo Nova, e mais 5 senadores ${ }^{29}$.

Sacramentada a FPMCAR soma-se ao ativismo político católico que, em 1991, sofre a primeira inflexão com a criação da Pastoral Parlamentar Católica (PPC), alterando a caracterizada atuaçáo política de lobby e de acessos privilegiados de religiosos da CNBB a políticos e ao governo (Vital; Lopes, 2012, p. 37). Comandada fundamentalmente por sacerdotes a PPC visa integrar parlamentares católicos (deputados e senadores) dispostos a participar de celebraçôes litúrgicas e reflexôes diretrizes católicas sobre questóes sociais. ${ }^{30}$ Ambas organizaçóes, a seu modo, constitui-se numa outra modalidade de pressão a autoridades e políticos para legislarem, regular e implantar em conformidade com a ética intramundana católica.

Não pretendo discutir aqui a natureza dessas duas representaçôes confessionais no Legislativo, apenas sinalizo que são de natureza distinta, na sua configuração e modos de atuar. Porém, ambas sinalizam para uma mudança significativa no interior da Igreja Católica que, ainda insistindo em não ter representação institucional salienta oficialmente sua presença confessional através de representaçôes católicas no Congresso. Enquanto isso, o intenso ativismo político da RCC, como vimos nas primeiras três frentes carismáticas (Ministério Fé e Política, Instituto Thomas More e ENCRISTUS), prepara quadros dirigentes para assumirem postos na arena política e intensifica a

${ }^{29}$ Disponível em: <http://www.camara.leg.br/internet/deputado/frenteDetalhe.asp?id=53496>. Acesso em: 20 set. 2017.

${ }^{30}$ Disponível em: <https://goo.gl/eEY1e8>. Acesso em: 21 set. 2017. 
formação dos religiosos políticos como garantia da presença do catolicismo institucional na disputa eleitoral.

\section{SEMELHANÇAS, DIFERENÇAS, INFLEXÕES, SUSPEITAS}

Avanço na argumentação sobre essas inflexões do modus operandi político da Igreja Católica, saindo do lobby para uma representação confessional que nos últimos anos se consolida, sinalizando para uma nova expressão pública e para outra relaçáo da igreja com o Estado e com a diversificação interdenominacional do ativismo evangélico e seus religiosos políticos.

Neste ínterim, o ativismo carismático opera como uma corrente de transmissão da Igreja Católica que dá suas diretrizes por meio do papado, episcopado, sacerdotes e os leigos as incorporam como princípios a serem traduzidos politicamente (Esquivel, 2013, p. 427). Assim, ele lança mão da rede de influências que rende o peso institucional para legislar em consonância com os interesses da hierarquia, constituindo-se numa das inflexões e atualização do modus operandi político da igreja. Num vai-vém de aproximação política e de distanciamento identitário, os carismáticos terão que negociar a todo momento a presença do ativismo evangélico.

Do outro lado, é realidade que o ingresso na política nacional não é apenas um efeito do crescimento demográfico dos evangélicos, mas, também, fruto de seu tenaz ativismo, do fervor de seus religiosos políticos e do reconhecimento partidário, como já vimos. Ao mesmo tempo, eles refinam seu pragmatismo eleitoral com estratégias multiposicionadas que ampliam sua inserção partidária, admitindo negociaçóes ideológicas para sustentar bandeiras conservadoras nas casas legislativas. $\mathrm{O}$ amálgama dessas tendências favoreceu a construção dos degraus que permitiu os evangélicos ascender as instâncias de poder, o cortejo partidário e a atenção dos religiosos políticos católicos e suas instituiçóes.

Mas, se o pragmatismo eleitoral assemelha os ativismos religiosos na política, há diferenças entre eles. De acordo com Maria das Dores Machado, 
a ênfase das candidaturas oficiais nos carismáticos recaem no laicato, enquanto nos pentecostais recaem nos agentes eclesiásticos, bispos e pastores, que chegam até a renunciar as suas funçóes religiosas para atuar politicamente. Outra diferença está no alvo da formação política. Os pentecostais selecionam pastores(as) e missionários(as), enquanto que os carismáticos investem nos leigos, "convocados para integrar a 'Tropa de Elite Cristã', por isso requerem uma preparação de caráter mais espiritual" (Machado, 2015, p. 61). A autora sublinha a admiração que os carismáticos nutrem pela atitude apaixonada com que os religiosos políticos evangélicos defendem os valores da moralidade cristã, enfrentam os movimentos sociais e o poder Executivo para fazer prevalecer seus interesses. Admiração que se estende ao ativismo que, como vimos nos depoimentos, impulsiona o estilo político carismático.

Ambos ativismos, com seus ardorosos representantes nas instâncias legislativas constituem-se em portavozes de suas igrejas, manipulam suas identidades religiosas e institucionais e dão amostras de relativo sucesso na empreita eleitoral, como mostram os dados das eleiçóes de 2016. Quando se aproximam católicos e evangélicos para sancionar leis em sintonia com suas propostas de princípios éticos intramundanos acionam seus recursos institucionais e participam da dinâmica tensa de ter que negociar com outros atores políticos, como os movimentos sociais, para que suas propostas prevaleçam.

Ao contestar os movimentos sociais, os papéis sociais preestabelecidos, tidos como tradicionais, e reivindicarem direitos, parlamentares evangélicos, carismáticos e conservadores unem-se em conjecturações políticas com a finalidade de fazer valer um tipo de interpretaçáo da verdade cristã. Igualmente se aliam numa cruzada ferrenha, lançando mão de todas as armas teológicas, argumentos disseminadores de pânicos morais, campanhas difamatórias e passeatas multitudinárias, como atestam recentes trabalhos acadêmicos (Vital; Lopes; Lui, 2017; Natividade, 2016). Alianças que, de um lado, reverberam numa dinâmica social de intolerância religiosa desencadeadora de violências e no questionamento aos modos de apropriação dos mecanismos democráticos da razão, o consenso e a lei, para extinguir 
antagonismos ideológicos. Do outro lado, reforçam a generalização de estigmas que identificam os pentecostais (carismáticos e evangélicos) como fundamentalistas.

Enfim, a sistematização dos dados quantitativos coletados por Carvalho Junior e Oro, no texto "Eleiçóes municipais 2016: religião e política nas capitais brasileiras", mostram o firme avanço dos segmentos religiosos, representados por seus políticos, nas instâncias legislativas da esfera pública do país. Escondem, evidentemente, porque não é a intenção da pesquisa, a distância entre as bases do eleitorado religioso, igrejas e grupos, e seus representantes políticos nas instâncias de poder, esses últimos nem sempre atuam de forma subalterna a elas, mas como portadores de seus próprios interesses e hermenêuticas e a de determinados setores da liderança institucional (Vital; Lopes; Lui, 2017, p. 119).

Nessa trilha de distanciamento é possível imaginar que muitos dos serviços pastorais que visam o compromisso com açóes de resgate à cidadania, desenvolvidas no interior das igrejas evangélicas e da RCC podem enveredar, na prática, na contramão ideológica e teológica de seus representantes políticos. Inumeráveis desses serviços, rapidamente rastreados com um clique na Web, quando somados a outras açóes de iniciativa menos identificáveis compóem uma corrente subterrânea que irriga novas relaçóes entre religião e política, presente no cotidiano das práticas institucionais ou em modestas iniciativas de seus membros.

Se for assim, os protagonistas desses serviços talvez estejam abrindo brechas de dissidência interna que, mesmo não manifestando-se publicamente ou rompendo organicamente com suas instituiçóes, vão na contramão de seus representantes nas esferas de poder. Isso porque, talvez os agentes religiosos nas bases sociais das igrejas caminham no antifluxo dos modelos teológico-políticos tidos como oficiais, apropriando-se, na prática, do arcabouço teológico que lhes é disponibilizado. Tendo a concordar com Machado e Burity (2014, p. 625) que afirmam que há "um sentimento crescente, pelo menos entre a liderança mais jovem do pentecostalismo brasileiro, de 
autocrítica e engajamento". Acho que essa percepçáo encontra-se, também, nos protagonistas desses serviços pastorais.

É nessa percepção, entre as novas geraçôes e os ativistas sociais religiosos, que teremos que procurar como operam e se gestam outros mecanismos que articulam religiáo e política? Segundo Renato Janine Ribeiro, hoje no Brasil podemos distinguir dois tipos de direitas: a democrática (que não quer o controle do Estado sobre a economia, quer menos direitos sociais e trabalhaistas) e a comportamental (não se limita a uma pauta econômica, traz junto uma pauta moralista, muito conservadora ${ }^{31}$. A que tipo de direita se alinham esses protagonistas? Para onde são direcionados seus esforços? Quais matizes e conteúdos de conservadorismo germinam em suas práticas? Ou são religiosos progressistas? Quer dizer, comprometidos com defesa das minorias, críticos dos comporramentos extremistas e conservadores no espaço público e político, somam esforços com coletivos sociais nacionais e internacionais (Vital; Lopes; Lui, 2017, p. 122). Representam uma novidade no ativismo político ou confirmam o atual? Nessas brechas dissidentes implícitas, ou não, quem sabe estejam roendo as bases do establishment do ativismo político, católico e evangélico, dos últimos anos, provocando novas inflexôes em ambos. Eis aí mais um desafio de pesquisa qualitativa.

${ }^{31}$ Disponível em: <https://www.nexojornal.com.br/expresso/2017/10/03/Por-queobras-e-exposi $\% \mathrm{C} 3 \% \mathrm{~A} 7 \% \mathrm{C} 3 \% \mathrm{~B} 5$ es-de-arte-est $\% \mathrm{C} 3 \% \mathrm{~A} 30$-protagonizando-o-debatepol\%C3\%ADtico>. Acesso em: 4 out. 2017. 


\section{REFERÊNCIAS}

ALMEIDA, Ronaldo. Os Deuses do Parlamento. Novos Estudos CEBRAP, São Paulo, Especial 107, p. 71-79, jun. 2017.

BURITY, Joanildo Albuquerque; MACHADO, Maria das Dores Campos (Org.). Os Votos de Deus: Evangélicos, Política e Eleiçôes no Brasil. Recife: Massangana, 2006.

CARRANZA, Brenda. Cristianismo Pentecostal: nova face da Igreja Católica. In: MOREIRA, Alberto da Silva; TROMBETTA, Pino Lucà (Org.). Pentecostalismo globalizado. Goiânia: Editora da PUC-Goiás, 2015. p. 71-93. . Catolicismo midiático. Aparecida, SP: Ideias \& Letras, 2011.

. Perspectivas de neopentecostalizaçáo católica. In: Carranza, Brenda; Mariz, Cecília; Camurça, Marcelo (Org.). Novas Comunidades Católicas: em busca do espaço pós-moderno. Aparecida: Ideias \& Letras, 2009. p.33-58.

CARRANZA, Brenda; MARIZ, Cecilia. O catolicismo brasileiro de exportação: o caso Canção Nova. In: Rocha, Cristina; Vásquez, Manoel A. (Org.). A diáspora das religióes brasileiras. Aparecida: Ideias \& Letras, 2016. p.149-180. CORTEN, André; DOZON, Jean-Pierre; ORO, Ari Pedro. Igreja Universal do Reino de Deus: novos conquistadores da fé. São Paulo: Paulinas, 2003.

ESQUIVEL, Juan Cruz. Igreja, Estado e Política: estudo comparado no Brasil e na Argentina. Aparecida: Santuário, 2013.

FREITAS, Marcos Vinícius Reis. Politica e religião: participação política dos católicos carismáticos do Brasil. 2015. 196 f. Tese (Doutorado em Sociologia)-Universidade Federal de São Carlos, São Carlos, 2016.

. Política e Religião: o envolvimento dos católicos carismáticos na política brasileira. 2011. 119 f. Dissertação (Mestrado em Ciências Humanas)Universidade Federal de São Carlos, São Carlos, 2011. 
MACHADO, Maria das Dores Campos. Politica e Religião: participação dos evangélicos nas eleiçóes. Rio de Janeiro: Editora FGV, 2006.

. Religiáo e Política no Brasil Contemporâneo: uma análise dos pentecostais e carismáticos católicos. Religiäo \& Sociedade, Rio de Janeiro, v. 35, n 2, p. 45-72, 2015. Disponível em: <https://dx.doi.org/10.1590/ 0100-85872015v35n2cap02>. Acesso em: 12 out. 2017.

MACHADO, Maria das Dores Campos; BURITY, Joanildo. A Ascensão Política dos Pentecostais no Brasil na Avaliação de Líderes Religiosos. Dados, Rio de Janeiro, v. 57, n. 3, p. 601-631, set. 2014. Disponível em: <http://www.scielo. br/scielo.php?script=sci_arttext\&pid=S001152582014000300601\&lng=en \&nrm=iso>. Acesso em: 12 out. 2017.

MARIANO, Ricardo. Pentecostais e Política no Brasil. ComCiência, n. 65, mar. 2005. Disponível em: <http://www.comciencia.br/reportagens/ 2005/05/13.shtml>. Acesso em: 12 out. 2017.

MARIANO, Ricardo; HOFF, Marcio; DANTAS, Toty. Evangélicos Sanguessugas, presidenciáveis e candidatos gaúchos: a disputa pelo voto dos grupos religiosos. Debates do NER, Porto Alegre, ano 7, v. 2, n. 10, p. 65-78, jul./ dez. 2006.

NATIVIDADE, Marcelo. Margens da politica: Estado, direitos sexuais e religiosos. Rio de Janeiro: Garamond, 2016.

ORO, Ari Pedro. Religiáo e eleiçóes 2000 em Porto Alegre. Debates do NER, Porto Alegre, ano 2, n. 3, p. 9-70, 2003.

ORO, Ari Pedro; MARIANO, Ricardo. Eleiçóes 2010: Religiáo e Política no Rio Grande do Sul e no Brasil. Debates do NER, Porto Alegre, ano 11, n. 18, p. 10-38, jul./dez. 2010.

ORO, Ari Pedro; SCHOENFELDER, Rosilene. A religião nas eleiçôes 2006 no Rio Grande do Sul: o que há de novo. Debates do NER, Porto Alegre, ano 7, n. 10, p. 7-26, jul./dez. 2006. 
PROCOPIO, Carlos Eduardo Pinto. Carismatismo católico e eleições no Brasil. Ciencias Sociales y Religión/Ciências Sociais e Religião, Porto Alegre, ano 14, n. 16, p. 79-99, ene./jun. 2012.

TAVALD, Marcelo. Demonização da política ou a política demonizada? Os evangélicos e as eleiçóes federais de 2006. Debates do NER, Porto Alegre, ano 7, n. 10, p. 79-88, jul./dez. 2006.

VITAL, Christina. A ascensão do pentecostalismo: da religião à política. Revista IHU On-line, abr. 2017. Entrevista concedida a Patrícia Fachin. Disponível em: <http:/www.ihu.unisinos.br/159-noticias/entrevistas/ 566735-ascensao-do-pentecostalismo-da-religiao-a-politica-entrevistaespecial-com-christina-vital>. Acesso em: 12 out. 2017.

VITAL, Christina; LOPES, Paulo Victor Leite; LUI, Janayna. Religião e Política: medos sociais, extremismo religioso e as eleiçóes 2014. Rio de Janeiro: Fundação Heinrich Böll; Instituto de Estudos da Religiáo, 2017.

VITAL, Christina; LOPES, Paulo Víctor Leite. Religião e Política: uma análise da atuação de parlamentares evangélicos sobre direitos das mulheres e de LGBTs no Brasil. Rio de Janeiro: Fundação Heinrich Böll, 2012.

Recebido em: 11/10/2017 Aprovado em: 11/10/2017 


\section{RELIGIÃO E POLÍTICA NO BRASIL E AS ELEIÇÕES DE 2016: ALGUMAS TENDÊNCIAS}

\section{Marcelo Tadvald}

A imbricação entre religião e política é tema consagrado na academia brasileira desde, ao menos, as décadas de 1980 e 90, e seria exaustivo e desnecessário neste momento recuperar o grande número de trabalhos e de volumes importantes que observam esta questão. Tendo em vista que grande parte da pertinência de um tema de pesquisa reside em sua relevância social, a expressiva quantidade de estudos sobre religião e política ademais revela as múltiplas formas de sua relação e os mais diferentes lugares e instâncias de sua manifestação.

A análise das candidaturas de religiosos e da formação dos governos, como se pode resumir um fenômeno mais abrangente, por certo são aspectos fundamentais quando pensamos na relação entre religião e política sob o ponto de vista institucional, ou no Estado, propriamente. E são muitas as formas pelas quais esta relação pode ser percebida, constituindo-se os parlamentos em lócus privilegiados para a observação e análise. E o que outrora se restringia basicamente ao Poder Legislativo, atualmente se expande mediante o crescimento de candidaturas de religiosos aos cargos Executivos, o que amplia a nós, enquanto pesquisadores e pesquisadoras, o universo e as questóes por considerar.

Por se apresentar por todo o lugar a relação entre religião e política, e reputando a tradição antropológica de mirar para o particular, por vezes sentimos falta de trabalhos que busquem abarcar esta questão de forma mais abrangente. Por exemplo, sobre uma perspectiva brasileira que não se resuma ao Congresso Nacional - o panóptico supremo para se observar a religião e a política institucional neste país continental, mas antes de tomá-la

1 Doutor em Antropologia Social e Pesquisador do Núcleo de Estudos da Religião da UFRGS, Brasil. Contato: marcelotadvald@gmail.com 
segundo todos os Estados da Federação, a partir das eleiçôes municipais de suas capitais, por exemplo.

Desta forma, reside na atualidade do tema, mas especialmente no meritoso cumprimento do desafio acima proposto, a importância do trabalho de Erico Carvalho e de Ari Pedro Oro, disponível neste volume e que conduz os comentários aqui partilhados.

Faltava-nos este olhar mais abrangente sobre as recentes eleiçóes, perscrutadas pelo filtro religioso: uma tarefa hercúlea, levada ao cabo pelos pesquisadores que não se furtaram em avaliar os cerca de dezessete mil candidatos concorrentes ao pleito de 2016 nas capitais brasileiras, oferecendo-nos muitos dados por considerar e para refletir.

\section{A PRINCIPAL TENDÊNCIA: "SER CRISTÃO”}

Os dados apresentados por Oro e Carvalho afirmam ou revelam algumas tendências observadas nos estudos de casos e de localidades particulares ${ }^{2}$, desde a esfera municipal, estadual ou da representação parlamentar federal que indicam a presença constante das "candidaturas religiosas", assim consideradas por se valerem do expediente religioso como linguagem e capital político. A principal delas consiste na prevalência de candidaturas cristás, especialmente do campo evangélico mediante denominaçóes já consideradas tradicionais no jogo político, como a Assembleia de Deus (AD), A Igreja Batista (IB) e a Igreja Universal do Reino de Deus (IURD).

No âmbito nacional, outra tendência importante que dialoga com os dados apresentados consiste no alinhamento quase que absoluto destas "candidaturas cristâs" com o "espectro ideológico da direita", ou seja, aquele

2 Ver, por exemplo: Burity e Machado (2006); Lima et al. (2004); Oro (2003); Pedde (2005); Trevisan (2013); Tadvald (2015b). Também estão disponíveis à consulta diversas coletâneas e dossiês que abordam tal universo, como alguns dos volumes temáticos da revista Debates do NER (ano 5, n. 6; ano 7, n. 10; ano 11, n. 18; ano 14, n. 23 e ano 16, n. 27). 
mais conservador, assumindo que, em termos políticos e morais, o cristianismo em muito se aproxima de uma postura pouco progressista e atualizada no contexto moderno dos Estados democráticos de direito baseados na promoçáo secular de cidadanias e equidades, notadamente naquilo que se refere a temas pertencentes ao campo da moral e dos costumes.

Em termos ideológicos, éticos e morais não há nenhuma incoerência nesta condição conservadora, exceto que, quando de sua imbricação na arena política e diante do princípio constitucional de laicidade do Estado brasileiro desde o advento da República, a medida cristã na construção da política nacional instituída, ainda que progressista em certas ocasiōes, parece-nos na atualidade mais danosa e prejudicial a certos temas do que agente de equidades e de avanços sociais.

Em resumo, a religião em geral e o cristianismo brasileiro em particular supostamente não combinam com a premissa moderna de um Estado inclusivo e promotor da diversidade social de sua nação. São diversos os casos que exemplificam esta prerrogativa e agora não se deve avançar sobre eles, contudo esta realidade pode ser observada facilmente e de maneiras e em locais diferentes, como as sistemáticas açóes parlamentares promovidas por "religiosos políticos" ${ }^{3}$ que incitam a intolerância e a falta de equidade social $^{4}$ ou medidas e arranjos legais e constitucionais que implicam satisfazer grupos e comunidades específicas em detrimento de outros 5 .

Inspirado por alguns clássicos, dos quais destaco o trabalho de Antônio Flávio Pierucci $(1996,2004)$, tenho me ocupado da ideia de que a notória diversidade religiosa brasileira é deveras atravessada pelo cristianismo de

3 Segundo a tipologia de Oro (2003), são assim considerados os sujeitos detentores de um pertencimento religioso anterior a sua eleição, que se utilizam deste pertencimento como capital político, mesmo que de forma sutil, e que, uma vez eleitos, mantêm o seu vínculo religioso de forma explícita.

4 Ver, por exemplo: Mariano, Hoff e Dantas, 2006; Morais, 2012; Oro, 2005; Oro, Carvalho e Scuro, 2017; Silva Jr, 2007; Tadvald, 2007, 2015 b.

5 Ver, por exemplo: Baldi, 2016; Miguel; Biroli e Mariano, 2017; Pêcego, 2015; Ranquetat Jr., 2010. 
formas múltiplas e complexas (Tadvald, 2015a, 2015b, 2016). Isto decorre da tradiçấo imposta pelo catolicismo colonial e do típico caráter antropofágico de nossa cultura, mediante a assimilação das diferenças ao ponto de sua fusão e transformaçáo em algo novo no sentido de cumprir às exigências de certo modelo instituído: "comum", "normativo", "nacional", "brasileiro", portanto distinto de sua condiçâao original.

Em termos religiosos, neste país é possível professar uma fé diferente da cristá, contanto que ela seja um tanto cristä de alguma forma. O caráter encompassador e de proximidade semântica entre religião, ética e moralidade (Mayblin, 2010; Fassin, 2012; Dullo; Quintanilha, 2015) facilitam este modelo normativo e assimilacionista e, por certo, não é de se estranhar a sua intensa penetraçáo no campo político nacional, este tâo desacreditado e carente desta "verdadeira sementeira de novas energias" (Ribeiro, 2002) de que se trata a religiáo.

Portanto, no Brasil, "religiáo", "ética", "moralidade" e "cristianismo" se confundem, produzindo arranjos próprios e fundamentais de nossa matriz secular. Há também de se considerar a diversidade contida no termo "cristianismo", e as diferentes formas de ser e de se perceber cristáo por aqui. Contudo, do ponto de vista institucional, da arena e do jogo político, no Estado propriamente, o cristianismo que ali se apresenta revela a sua face mais conservadora e, porque náo, segundo certos pontos de vista legítimos e ideologicamente fundamentados, reacionária.

Todavia neste ambiente instituído, em seu aspecto partidário, o alinhamento ideológico conservador da religião/cristianismo está devidamente representado na tipologia dos chamados "partidos cristáos" que, segundo apontado pelos autores em diálogo, são aqueles que se propóem a representar diretamente este segmento religioso e que possuem como bandeira a "defesa de valores do cristianismo". A pergunta que se impóe é justamente saber quais "valores" seriam estes? E, decorrente desta primeira inquietação, resta saber se, em termos políticos e sociais, "cristianismo" é sinônimo de "conservadorismo". 
Ao último questionamento parece mais razoável não os considerarmos sinônimos, e diversos exemplos históricos e atuais podem assim atestar. Mas tendo em vista de que quase a totalidade dos "religiosos políticos" eleitos segue a fé cristã, afinal quais valores cristãos (religiosos) estão sendo acionados na cena politica nacional?

Independente de sua origem étnica ou pertencimento religioso, a maioria das pessoas nascidas e/ou criadas no Brasil foi ou é educada como cristâ, de modo que a nós não é difícil supor quais seriam alguns dos princípios fundamentais desta inscrição, como a: "caridade", "benevolência", "abnegação", "humildade" entre outros mais. Por certo todos são termos apropriados e bem-vindos a um modelo de república representativa como é o caso da brasileira. Mas seriam estes os valores propriamente evocados pelos politicos religiosos no atual cenário político?

Essas questóes são pormenores de um fenômeno maior que reconhece que no Brasil os partidos cristáos organizados consistem, portanto em um produto natural da relaçáo entre cristianismo, moral e ética, certamente imbricados na sociedade e, por extensão, na cena política nacional. Contudo, em sua atuação, partidos e políticos cristãos parecem reproduzir as mazelas "antiéticas" e "antimorais" de seus correligionários seculares. Aqui a religião se configura ao cabo uma "sementeira de novas energias", que agrega muito em termos de capital político durante os pleitos, mas bem pouco no avanço da res publica agente de uma cidadania inclusiva e promotora da diversidade.

Também é importante mencionar que esta penetração do religioso (cristianismo) na política institucional brasileira não se dá apenas mediante a atuação dos "políticos religiosos confessos" e que formam bancadas suprapartidárias, forças de poder ou frentes de interesse junto ao poder público, ainda que suas posiçôes políticas sejam costumeiramente julgadas devido ao seu pertencimento e identidade religiosa conforme o caso. Por exemplo, um parlamentar da "bancada ruralista", quando é convocado a votar sobre matérias do campo da moral e dos costumes e, malgrado se posicionar absolutamente de acordo com a posição de seus colegas da "bancada evangélica", 
não tem sua posiçáo avaliada socialmente mediante o caráter religioso. Entretanto, o efeito é o mesmo.

\section{OUTRAS CATEGORIAS, OUTRAS TENDÊNCIAS}

A pesquisa de Carvalho e Oro confirmou a prevalência de candidaturas evangélicas por todo o pleito de 2016 nas capitais brasileiras. Por conseguinte, é também mais expressivo o seu sucesso eleitoral e a sua presença em todas as Câmaras Municipais das capitais. E, mais uma vez, permanecem a $\mathrm{AD}, \mathrm{IB}$ e a IURD capitaneando e liderando as estatísticas de candidaturas e eleiçóes logradas. São denominaçôes que de fato investem bastante em estratégias políticas e nas chamadas "candidaturas oficiais", não se furtando em angariar votos para os seus representantes legítimos dentre os seus fiéis nos templos e mídias que possuem.

Ademais, sua presença e, consequentemente, as campanhas políticas costumam se desenrolar desenvoltas nas grandes cidades como: Salvador, Fortaleza, Recife, Rio de Janeiro, São Paulo, Belo Horizonte e Porto Alegre, onde se encontram os seus principais "currais eleitorais", distribuídos nas metrópoles empobrecidas, repletas de gente "desencaixada economicamente" e em busca de entretenimento sagrado e profano como sáo os "cultos como lazer", e dispostos à sedução de narrativas como aquelas evocadas pela "Teologia da Prosperidade" ou mediante a "Guerra Espiritual" (Da Silva, 2007; Oro, Carvalho e Scuro, 2017; Tadvald, 2015a), expedientes devidamente capitalizados pelas denominaçóes no chamado "tempo da política" (Palmeira, 2002).

Os dados também indicam a baixa presença de candidaturas de outras matrizes religiosas, como a africana ou a esotérica. Esta constatação não é nova, contudo uma vez mais revela o baixo capital político que estes segmentos possuem, devido a aspectos históricos e sociais, mas também de seu próprio modelo constituinte e de organizaçáo baseada em sistemas de 
alianças religiosas e ancestrais (matriz africana) ou de fragmentação ideológica e cultural (matriz esotérica).

Tendo em vista os casos de intolerância que acomete a tais populaçôes, incluindo certas perseguições desde o próprio campo político instituído, tarda neste país que sua representatividade, especialmente na instância legislativa, se faça mais presente, ao assumirmos a realidade da penetração do religioso no campo político e da nossa natureza política não secular. Neste sentido, dentre todas as capitais, apenas Salvador logrou eleger dois afrorreligiosos em 2016, todavia algo modesto, mas deveras significativo.

Em termos de gênero, o pleito de 2016, ainda que sob o ponto de vista religioso, escancarou uma triste realidade: a da baixíssima participação e representação política de mulheres no Brasil. Pois que produto direto do machismo incrustado na cultura nacional, faz-se oportuno recuperar alguns dados para efeito comparativo e ilustrativo desta histórica distorção.

No âmbito federal, na legislatura passada da Câmara dos Deputados, as mulheres representavam $8,8 \%$ do quadro parlamentar, sendo que, na atual, as eleitas em 2014 representam em torno de 9,9\%. Destas, cerca de dez participam da atual Frente Parlamentar Evangélica nacional (FPE), ou 6,7\% da totalidade da bancada. No Senado, aquele pleito renovou somente um terço da Casa, e foram eleitas cinco senadoras entre as 27 vagas disponíveis, totalizando onze mulheres em um total de 81 cadeiras existentes, cerca de 13,5\%. Quanto aos Estados, em 2014, elegeram-se sete vice-governadoras e apenas uma mulher se tornou líder de executivo: trata-se de Suely Campos (PP), eleita em Roraima por ter ido ao segundo turno após substituir de última hora o marido, Neudo Campos, considerado "ficha-suja" e inelegível naquele pleito (Tadvald, 2015b).

Segundo os dados de Carvalho e Oro, os números melhoraram um pouco no que se refere à candidatura de mulheres em 2016, muito em função da alteração na Lei $n^{\circ} 12.034 / 2009$ que reforçou a obrigatoriedade dos partidos em reservar um terço das candidaturas para as mulheres, ainda que esta medida tenha provocado casos de suspeitas de "candidaturas femininas fantasmas" apenas para fechar as cotas das legendas. No âmbito 
religioso, é curioso contrastar que, malgrado o evidente crescimento do protagonismo feminino em alguns segmentos evangélicos, como o Batista e principalmente o neopentecostal, este campo resiste e persiste a baixa candidatura de políticas religiosas, ou seja, a promoção de lideranças femininas e a consequente indicação de mulheres pelas diferentes denominaçôes que participam diretamente dos pleitos políticos é absolutamente modesta e reverbera certos parâmetros machistas vigentes.

Portanto, no caso das candidaturas evangélicas de religiosas, seguimos observando que a ascensão feminina é absolutamente relativa, pois que muitas vezes construída mediante uma figura masculina, dado que grande parte das candidatas existentes são esposas ou filhas de líderes evangélicos homens, valendo-se, muitas vezes, mas nem sempre, do prestígio ou carisma pessoal de seus esposos ou pais, além de dificilmente pertencerem à hierarquia eclesial e aos colegiados e instâncias que definem as estratégias políticas das diferentes igrejas.

Ainda assim, segundo apontado e ainda que de forma modesta e reduzida, tem crescido a participação das mulheres dentro dos partidos conservadores segundo a existência de espaços partidários voltados para elas, além do surgimento de um partido específico, o PMB (Partido da Mulher Brasileira), considerado de ideologia conservadora, fundado em 2008 e registrado no Tribunal Superior Eleitoral em 2015.

O caso do PMB é exemplar de outra tendência: por mais paradoxal que pareça, a verdadeira situação de guerra pela qual passam as mulheres no arranjo social machista constituído (Segato, 2016) não costuma encontrar em suas lutas emancipatórias muitas aliadas eleitas e partícipes do poder institucional. Por exemplo, quando analisada a participaçáo das mulheres, sobretudo na arena parlamentar, constatou-se que em sua grande maioria elas se alinham aos típicos posicionamentos conservadores e machistas, incluindo sua posição e atuaçáo diante de temas a priori predicados à emancipação feminina, como o de direitos reprodutivos e direito ao aborto (Miguel; Biroli e Mariano, 2017). 
Outra tendência importante de se observar tendo em vista a imbricação do religioso e da política desde o pleito de 2016 são as "bandeiras" ou plataformas comuns evocadas pelas candidaturas religiosas que, quando cristãs, notadamente são apresentadas com ênfase na "defesa da família", "da moral" e da "luta contra a corrupção", esta, a rigor, um subproduto do campo da moralidade, levando-se em consideração os motivos recentes que haviam levado ao golpe de Estado contra a presidenta Dilma Rousseff em 2016.

Estas ênfases específicas se somam aos temas consagrados da "saúde", "educação" e "segurança”, mas é interessante notar que são questóes e pautas políticas peculiares do chamado establishment, ou seja, as instâncias estabelecidas e normativas da nação, enquanto que outros segmentos, por exemplo, mediante os candidatos afrorreligiosos analisados, costumam acionar outros discursos, como os da "luta contra a intolerância religiosa", contra o "racismo" e em defesa dos "direitos das minorias".

A realidade religiosa engendrada no campo político, o modo de sua inserção, atuação e preocupaçóes prementes evocam diretamente as desigualdades sociais da nação e as diferenças existentes entre fés e crenças mais estabelecidas, porquanto cristãs, e as demais. Não por acaso, no Brasil, onde se considera que nos últimos anos a liberdade religiosa atingiu patamares surpreendentes em se tratando de um país com grandes dificuldades de desenvolvimento econômico e social (Pierucci, 1996), os maiores índices de percepção de liberdade religiosa ainda se encontram entre adeptos de religiōes cristãs.

Segundo a pesquisa coordenada por Ari Pedro Oro (2012) na cidade de Porto Alegre a respeito da percepção de liberdade religiosa entre um grupo aleatório de cerca de trezentas pessoas, uma vez questionadas se: "você se sente livre para viver a sua fé?", as respostas mais positivas ficaram entre os entrevistados de religióes cristâs: espiritismo kardecista (90\%), evangélicos históricos $(89,5 \%)$, pentecostais $(74 \%)$ e católicos $(73 \%)$ e os menores índices se encontraram entre outras religióes: afrorreligiosos $(28,5 \%)$, religióes contemporâneas da cena nacional (32\%) - neopagãos, neoxamânicos, 
neoesotéricos, neotradicionais, ayahuasqueiros, orientalistas - e os sem religião $(39,1 \%)$.

Ainda que desde o microcosmo da capital gaúcha, este levantamento parece significativo e infere-se corresponder relativamente ao contexto nacional, prevalecendo números mais positivos para certas religióes que contém o componente cristão e menos positivos para as demais segundo cada região do país.

Fato é que prevalece o preconceito e o conflito de verdades sobre a fé, a moral, a ética e o costume dos outros, em acordo ou desacordo a certos princípios religiosos estabelecidos, ainda que de natureza alheia ao universo político, social e secular a que se propóe regular.

\section{TENDÊNCIAS E RESULTADOS ESTRATÉGICOS}

Conforme mencionado, temos por aqui os chamados "partidos cristãos", caracterizados pelo conservadorismo político. São eles: o Partido Trabalhista Cristão (PTC), o Partido Social Democrata Cristão (PSDC), o Partido Republicano (PR), o Partido Social Cristão (PSC) e o Partido Republicano Brasileiro (PRB). Todas estas legendas, senão propriamente coordenadas pelas denominaçóes, como no caso do $\mathrm{PRB} / \mathrm{IURD}$ ou do $\mathrm{PSC} / \mathrm{AD}$, são formadas ou ao menos agregam forte presença evangélica nos seus quadros, mas também da ala conservadora da Igreja Católica.

Ainda que preponderante, a presença e atuação religiosa na política não se restringe no Brasil a expressóes do cristianismo, conforme comprovou o último pleito soteropolitano ao eleger dois políticos afrorreligiosos. Nestes casos excepcionais e dissidentes do parâmetro ordinário, costuma-se observar candidaturas religiosas pulverizadas nos mais diferentes partidos e ideologias. Todo modo, é digno de registro a presença em todas as capitais estaduais de "partidos religiosos" e de "candidatos religiosos", conforme mostrou o estudo de Carvalho e Oro. Isto revela a atenção renovada que detém o caráter religioso no campo político, inclusive nas candidaturas seculares 
que disputam os cargos públicos. O caso dos prefeitos eleitos em 2016 é exemplar deste fenômeno recorrente.

Conforme indicou o estudo, a maioria dos prefeitos eleitos em 2016 nas capitais brasileiras pertence a partidos conservadores. Todos eles contaram com o apoio dos "partidos cristáos", além de terem cultivado uma boa relação com o campo evangélico local, muitas vezes manifestando apoio a este segmento e, inclusive em alguns casos, participando publicamente de atividades junto aos religiosos. Todavia o mais importante destaque consiste no alinhamento ideológico geral desses grupos religiosos e candidatos e partidos políticos com o caráter mais conservador da nação, sobretudo no apupado pleito de 2016, marcado por forte crise social e política que assolou o país e que perdura na temporalidade desta publicação.

$\mathrm{Na}$ atual conjuntura, a crise se revela também de maneira ideológica e a partir do esvaziamento de capitais políticos e de representatividade. Aliás, algo severo para uma naçáo construída e acostumada à ética do patriarcado e do populismo. Momentos assim são mais difíceis para a ascensão de quaisquer "minorias", inclusive religiosas, que carecem de instituiçóes públicas fortes e consolidadas capazes de promover e de garantir a sua diversidade.

O que se reinventou em 2014 em âmbito federal foi confirmado municipalmente em 2016: a prevalência da onda conservadora que toma o país. Este cenário se torna mais hostil à mudança social e é produto também dos confusos e peculiares alinhamentos ideológicos praticados na política brasileira, onde se convencionou executar programas de poder ao invés de programas de governo, reforçando dicotomias e modelos já fora de moda, esvaziando certas realidades e instituições sociais e a própria problematização da pluralidade ideológica e social da nação.

Ao cabo os projetos políticos disponíveis na atualidade parecem muito semelhantes, reproduzindo e reafirmando certo conservadorismo, por suposto de matriz cristã, mas não só, onde se convém não tocar mais diretamente em certas questóes, como a defesa de direitos sexuais e reprodutivos, a criminalização da homofobia e do machismo, a equidade de gênero, o racismo, a intolerância religiosa, entre outros mais, sob pena de que se perca 
considerável e imprescindível capital político em tempos de democracia ampliada, difusa e confusa, onde a concorrência é sempre maior. No geral, a sociedade brasileira é conservadora e, portanto, harmoniza-se melhor com discursos conservadores.

\section{CONSIDERAÇÓES FINAIS: \\ POR UMA BREVE HISTÓRIA DA ATUALIDADE}

São fatos de nossa história social e religiosa que nos levam a considerar, sobretudo o aspecto conservador constituinte de nossa identidade nacional, que de forma tradicional e produzido por certas noções morais e metafísicas, revelou-se e se mantém incompatível com alguns princípios republicanos e seculares modernos.

A verdade é que a relação entre religiáo e política no Brasil data desde a formação da nação, e antecede o próprio estabelecimento do colonizador. Desde esta época, mediante o catolicismo colonial europeu, o cristianismo esteve atrelado à governança e à ordem social, produzindo marcas indeléveis na identidade da naçáo.

Nos anos escolares, uma das primeiras imagens que tomamos contato quando estudamos a chegada dos portugueses costuma ser a aquarela de Victor Meirelles, "A primeira missa no Brasil", datada de 1861. Afresco da descoberta e da posse, naquela profusão edenista de mata e praia, sobretudo das gentes "primitivas e curiosas", podemos encontrar sem esforço a cruz e a espada, erguida ou a tiracolo do invasor.

Desde então, a história e o desenvolvimento do cristianismo no Brasil revela a sua importância na esfera política sob os mais diferentes aspectos, desde aqueles tempos da colonização até a atualidade. Contudo, esta relação nem sempre foi desprovida de tensóes e de conflitos, de aproximaçóes e de afastamentos. Mas devido ao caráter particular e múltiplo do cristianismo nacional e sua tradicional relaçáo com a governança, a ordem social e a esfera da moral e dos costumes, a naçáo pode assim se conceber cristá e notadamente conservadora. 
Especialmente a partir do século XIX, mediante novas ondas imigratórias europeias e a ascensão de outros grupos sociais, o curso da história e a pluralidade social constituída no Brasil puderam ampliar o espectro do cristianismo para além dos grupos católicos. A partir de sua visão mais imanente e pragmática e conforme permitiu o contexto histórico e político, o múltiplo campo evangélico que se desenvolveu por aqui produziu o fenômeno das candidaturas religiosas ao perceber no Estado as novas frentes missionárias de estabelecimento do sagrado e de embate e enfrentamento do mal e dos demônios, afeitos que são aos locais de poder e de vaidade, como costumam ser quaisquer arenas políticas e partidárias.

Desta forma, os evangélicos foram pioneiros e planificaram a inserção direta na política de grupos sociais e religiosos não católicos. Ainda sob a égide cristã, por outro lado, os candidatos católicos na maioria dos casos só assumiram atitude militante comparável à dos evangélicos quando ligados a movimentos como o da Renovação Carismática Católica. Nos demais casos seu pertencimento é insinuado sutilmente ou mencionado com pouca ênfase.

Sob o ponto de vista eleitoral, a relação da política e da religião no país assim transbordou o catolicismo e mais recentemente tem transbordado o evangelismo, quer dizer, o próprio cristianismo, quando observamos cada vez mais a candidatura de outros representantes religiosos, como os da matriz africana ou esotérica, ainda que esses não alcancem o mesmo sucesso que gozam os representantes das esferas cristâs. É, ademais um tanto de nossa história social que se atualiza no jogo político da nação, qual seja a instância de poder ou de legitimação.

Em termos de Brasil, não soa conflitante, portanto a relação da religiáo com a política mesmo depois de auferido o princípio republicano constitucional secular de ordenamento social. Aliás, neste país, a cada dia soa mais atemporal esta máxima de Otávio Velho (2012, quarta capa): "quem acha que religiáo e política não se misturam, não entende nada de religião, nem de política”. 


\section{REFERÊNCIAS}

BALDI, C. A. Novo constitucionalismo, religióes afro e laicismo/secularismo: uma (não) discussão pendente. Empório do Direito, Florianópolis, ago. 2016. Disponível em: <http://emporiododireito.com.br/leitura/novo-constitucionalismo-religioes-afro-e-laicismo-secularismo-uma-nao-discussao-pendente-1>. Acesso em: 17 ago. 2016.

BURITY, J.; MACHADO, M. D. C. Os votos de Deus: evangélicos, política e eleições no Brasil. Recife: Fundação Joaquim Nabuco; Editora Massangana, 2006.

DA SILVA, V. G. (Org.). Intolerância Religiosa: impactos do neopentecostalismo no campo religioso afro-brasileiro. São Paulo: Editora da Universidade de São Paulo, 2007. p. 303-323.

DULLO, E.; QUINTANILHA, R. A sensibilidade secular da política brasileira. Debates do NER, ano 16, n. 27, p. 173-198, 2015.

FASSIN, D. (Org.). A companion to moral anthropology. Malden: Wiley -Blackwell, 2012.

LIMA, A. J. F. et al. Vereadores católicos: elementos para a reflexão sobre a diversidade articulada no campo político. Debates do Ner, Porto Alegre, ano 5, v. 2, n. 6, p. 35-62, dez. 2004.

MARIANO, R.; HOFF, M.; DANTAS, T. Y. S. Evangélicos sanguessugas, presidenciáveis e candidatos gaúchos: a disputa pelo voto dos grupos religiosos. Debates do NER, ano 7, n. 10, p. 65-78, 2006.

MAYBLIN, M. Gender, Catholicism, and Morality in Brazil: Virtuous Husbands, Powerful Wives. New York: Palgrave Macmillan, 2010.

MIGUEL, L. F.; BIROLI, F; MARIANO, R. O direito ao aborto no debate legislativo brasileiro: a ofensiva conservadora na Câmara dos Deputados. Opinião Pública, vol. 23, n. 1, p. 230-260, 2017. 
MORAIS, M. R. Políticas públicas e a fé afro-brasileira: uma reflexão sobre ações de um Estado laico. Ciencias Sociales y Religión/Ciências Sociais e Religião. Porto Alegre, v. 14, n. 16, p. 39-59, 2012.

ORO, A. P. Princípios religiosos e práticas políticas de "religiosos políticos" e "politicos laicos" no sul do Brasil. 2003. Palestra apresentada na Conferência Internacional da Societé Internationale De Sociologie Des Religions, 2003.

. O sacrifício de animais nas religióes afro-brasileiras: análise de uma polêmica recente no Rio Grande do Sul. Religião e Sociedade, Rio de Janeiro, v. 25, n. 2, p. 11-31, 2005.

. Liberdade religiosa no Brasil: as percepçôes dos atores sociais. In: ORO, A. P. et al (Org.). A religião no espaço público: atores e objetos. São Paulo: Terceiro Nome, 2012. p. 181-193.

ORO, A. P.; CARVALHO JUNIOR, E. T.; SCURO, J. O sacrifício de animais nas religióes afro-brasileiras: uma polêmica recorrente no Rio Grande do Sul. Religião e Sociedade, Rio de Janeiro, v. 37, n. 2, 2017. No prelo.

PALMEIRA, M. Política e tempo: nota exploratória. In: PEIRANO, M. (Org.). O dito e o feito: ensaio de antropologia dos rituais. Rio de Janeiro: Relume Dumará, 2002. p. 171-177.

PECCEGO, D. N. O tratamento jurídico-político conferido à religião pelo direito brasileiro: modelos, antecedentes e atualidade. Quaestio Iuris, Rio de Janeiro, v. 8, n. 3, p. 1879-1894, 2015.

PEDDE, V. “Cabeça, sim; cauda, não!”: um estudo antropológico sobre os evangélicos na Assembléia Legislativa do Rio Grande do Sul. 2005. 415 f. Tese (Doutorado em Antropologia Social)-Instituto de Filosofia e Ciências Humanas, Universidade Federal do Rio Grande do Sul, Porto Alegre, 2005.

PIERUCCI, A. F. Liberdade de cultos na sociedade de serviços. In: PIERUCCI, A. F; PRANDI, R. (Org.). A realidade social das religióes no Brasil. São Paulo: Hucitec, 1996. p. 275-293. 
. Bye bye, Brasil: o declínio das religiōes tradicionais no Censo 2000. Estudos Avançados, São Paulo, v. 18, n. 52, set./dez. 2004.

RANQUETAT JUNIOR, C. A. O acordo entre o governo brasileiro e a Santa Sé e a Lei Geral das Religiōes: Estado, religião e política em debate. Debates do NER, ano 11, n. 18, p. 173-191, 2010.

RIBEIRO, R. J. Religião e política no Brasil contemporâneo. In: FRIDMAN, L. C. (Org.). Política e cultura, século XXI. Rio de Janeiro: ALERJ; Relume Dumará, 2002. p. 99-110.

SEGATO, R. L. La guerra contra las mujeres. Madrid: Traficantes de Sueños, 2016.

SILVA JR, H. Notas sobre sistema jurídico e intolerância religiosa no Brasil. In: DA SILVA, V. G. (Org.). Intolerância Religiosa: impactos do neopentecostalismo no campo religioso afro-brasileiro. São Paulo: Editora da Universidade de São Paulo, 2007. p. 303-323.

TADVALD, M. Direito litúrgico, direito legal: a polêmica em torno do sacrifício ritual de animais nas religiôes afro-gaúchas. Caminhos, Goiânia, v. 5, n. 1, p. 129-147, jan./jun. 2007:.

- Veredas do sagrado: Brasil e Argentina no contexto da transnacionalização religiosa. Porto Alegre: Cirkula, 2015a.

- A reinvenção do conservadorismo: os evangélicos e as eleiçóes federais de 2014. Debates do NER, ano 16, n. 27, p. 259-288, 2015 b.

. Religião e diversidade no Brasil: questôes de identidade. In: MEIRELLES, M; MOCELIN, D; RAIZER, L. (Orgs.). Relaçôes étnico-raciais e diversidade na escola. Porto Alegre: Cirkula, 2016. p. 105-126.

TREVISAN, J. A frente parlamentar evangélica: força política no estado laico brasileiro. Numen: Revista de Estudos e Pesquisas em Religiáo, Juiz de Fora, v. 16, n. 1, p. 581-609, 2013. 
VELHO, O. Contracapa. In: ORO, A. P; STEIL, C. A; CIPRIANI, R; GIUMBELLI, E. A religião no espaço público: atores e objetos. São Paulo: Terceiro Nome, 2012.

Recebido em: 03/08/17 Aprovado em: 23/09/17 



\title{
RESPOSTA AOS COMENTÁRIOS
}

\author{
Erico Tavares de Carvalho Junior ${ }^{1}$ \\ Ari Pedro Oro ${ }^{2}$
}

Antes de tudo faz-se necessário expressar um par de agradecimentos: aos editores de Debates do NER, pela acolhida do nosso texto, e aos comentadores, pela disponibilidade em lê-lo e pela generosidade e qualidade dos seus comentários. Como o leitor observou, os quatro comentaristas (Paul Freston, Cecilia Mariz, Brenda Carranza e Marcelo Tadvald), cada um a seu modo, aprofundam as reflexóes presentes em nosso texto, avançam novas questóes, abrem novas pistas e sugerem novos desdobramentos. Isto mostra quão interessante e cientificamente produtiva é a dinâmica adotada por esta revista de convidar pessoas qualificadas para reagirem a um texto base, oportunizando aos seus autores a tréplica aos comentários. Entretanto, neste espaço não pretendemos responder as indagaçóes constantes nos textos acima, mas táo somente comentar alguns pontos e discorrer sobre algumas tendências compartilhadas e questionamentos comuns que permanecem e demandam aprofundamentos.

Iniciamos esclarecendo a intenção que nos moveu a produzir o conjunto dos dados constantes em nosso texto. Afinal, qual seria a utilidade de analisar em torno de 17 mil perfis de candidatos, quase que inteiramente por meios digitais, considerando as limitaçóes de um tal empreendimento? Pareceria óbvio afirmar que qualquer quantificação em um universo de pesquisa pouco conhecido é sempre útil. Porém, há que se considerar a relação custo-benefício de tal esforço. Neste sentido, pensamos que um movimento inicial e amplo de quantificação e análise poderia ter um efeito positivo na

1 Mestrando do PPGAS/UFRGS e colaborador do Núcleo de Estudos da Religião (NER/ UFRGS). Contato: erico.carvalho@hotmail.com

2 Professor titular do Departamento de Antropologia da Universidade Federal do Rio Grande do Sul e pesquisador do CNPq. Contato: arioro@uol.com.br 
medida em que oportunizaria a obtenção de uma visão do conjunto do cenário nacional, relativamente às candidaturas religiosas no pleito eleitoral de 2016, ao mesmo tempo em que poderia incentivar outras iniciativas semelhantes, mesmo que focadas em localidades ou regiōes específicas. Foi com este espírito que o trabalho foi realizado e todos os comentaristas o captaram bem, destacando também que entregamos aos leitores tabelas para serem analisadas mais do que nós pudemos fazê-lo no texto. E, mais ainda, nossos interlocutores levaram avante o nosso empreendimento, como realizou especialmente Carranza, mas todos, de alguma forma, apontaram novas frentes de pesquisa.

Assim, além do diálogo frutífero que os quatro comentaristas realizaram com o nosso texto vemos com satisfação que dois deles, Branda Carranza e Marcelo Tadvald, ampliaram o conteúdo por nós abordado com dados de pesquisas que eles próprios realizaram nos últimos anos.

De uma forma geral, compartilhamos com os quatro comentaristas a necessidade de se aprofundar a relevância ou o significado dos partidos políticos que carregam consigo a nominata de "cristãos". Trata-se simplesmente de um significante vazio ou carregam eles valores específicos? E, se assim for, qual seria a preeminência e a incidência da condição "cristâ" na conduta dos políticos filiados a aqueles partidos? Por outro lado, como também destacam os comentaristas, há que se averiguar as franjas de significados existentes em candidaturas provenientes do campo evangélico que se afirmam denominacionalmente daquelas que se apresentam como "evangélicas" ou "cristãs", bem como, de outra parte, daquelas inscritas no amplo espectro "católico". Ou seja, que identidade religiosa mobilizam os candidatos a cargos eletivos que se dizem "evangélicos" ou "católicos"? Que efeitos produz isto sobre os fiéis eleitores? Os comentaristas também nos induzem, direta ou indiretamente, a nos perguntarmos sobre os efeitos intra-institucionais dos religiosos políticos que deixaram as suas igrejas ou engajamentos religiosos e passaram a atuar na arena politica. Em outras palavras, e para além do que já sabemos sobre o papel desempenhado pelos religiosos políticos enquanto representantes das 
suas bases eleitorais, no caso, igrejas, e supostamente defensores da moralidade cristá, impor-se-ia indagar - especialmente sabendo, como destacou Carranza, que no campo evangélico os eleitos provem majoritariamente dos escalóes superiores das igrejas, enquanto pastores, presbíteros e bispos, diferentemente dos candidatos católicos, que pertencem majoritariamente ao laicado - o que ocorre no interior das denominaçóes quando as lideranças que antes cumpriam um papel de destaque nas igrejas agora, no exercício do mandato político, tendem a delas se distanciarem? Qual seria o "grau de satisfação" ou o "grau de frustração" que o novo papel social cumprido pelos líderes das igrejas produz institucionalmente, mas, sobretudo, do ponto de vista das relaçóes pessoais? Estes são alguns entre muitos outros questionamentos "genéricos" que os comentários que acabamos de ler nos provocam, no momento.

Há muitos tópicos ressaltados pelos comentadores como forma de problematização ao nosso texto. Tomemos somente alguns exemplos. Paul Freston destaca que há uma enorme dificuldade em realizar comparação entre pertencimentos religiosos distintos do ponto de vista da explicitação deste pertencimento, chegando a ser isto muito pouco revelador. De fato, a construção de uma imagem pública com finalidades eleitorais envolve, por um lado, uma estratégia individual e/ou coletiva, assim como o contexto em que se desenvolve tal candidatura. Assim, tomando os católicos como exemplo, encontraremos candidatos que afirmam seu pertencimento, há aqueles que não o afirmam diretamente, mas não o escondem, frequentando grupos e cultos católicos e expondo isto em suas redes sociais, e há aqueles cuja classificação formal torna-se é difícil uma vez que, já que estão entre a massa de brasileiros que assumem esta identidade católica genérica, incluindo aí aqueles que sobrepóem à imagem católica, uma imagem de político laico. Ainda dentro desta problemática, podemos tomar os dados referentes aos afrorreligiosos em Porto Alegre, onde podemos observar, não um crescimento das candidaturas de afrorreligiosos, mas a explicitação desta identidade por candidatos que já haviam concorrido ou mesmo sido eleitos 
em eleições anteriores. Desta forma, o contexto político e religioso, assim como a construção da candidatura com base na escolha de um eleitorado, faz com que esta explicitação seja relativa.

Tal argumentação vai ao encontro da colocação de Freston e de Carranza acerca das discrepâncias nos números levantados, uma vez que uma das fragilidades de tal tipo de dado reside justamente no desconhecimento em profundidade dos contextos locais de cada capital, o que dificulta o acesso a alguns dados que para um pesquisador local seriam bastante óbvios. Daí, reiteramos, a necessidade de pesquisas locais. Quanto ao questionamento de Carranza acerca da diferença entre o número de candidatos católicos levantados neste estudo em comparação com o estudo de Marcos Freitas, nos inclinamos a considerar um duplo efeito sobre o dado: o primeiro está relacionado com a dificuldade de acesso já referida e o segundo repousa na própria estratégia adotada pelo candidato, que pode ter preferido não explicitar o seu pertencimento, mesmo estando identificado como um "catolicismo militante". Assim, com base na pesquisa mais aprofundada realizada em Porto Alegre, propomos que a participação em um grupo de formação política para candidatos católicos não necessariamente resulta na adoção de uma identidade católica durante a campanha. Considerando ainda o lugar ocupado pelo catolicismo em cada contexto os dados de Curitiba parecem ir nesta direção, uma vez que o crescimento evangélico nesta capital parece pressionar os candidatos católicos a se posicionarem.

Ainda nesta direção, o questionamento de Freston quanto à incongruência entre o número de vereadores evangélicos eleitos no centro-oeste e a importância deste segmento para as eleiçôes a prefeito é de fato instigante, pois também nos pareceu intrigante a ponto de realizarmos uma cuidadosa revisão dos dados. Propomos a título hipotético que a identidade evangélica nesta região tornou-se lugar-comum, a ponto de igualar-se ao catolicismo. Assim sendo, se, por um lado, opor-se abertamente contra os segmentos evangélicos tornaria inviável o sucesso eleitoral, eliminando, desta forma, uma atitude militante por parte destes últimos, por outro, parece evidenciar 
que os evangélicos possuem mais força dos que se pode quantificar, e assim o dado apresentaria uma distorção, já que a especificidade local conduziria os candidatos a não explicitarem a sua religiosidade nas candidaturas a vereador, mas seria mobilizada pelos candidatos a prefeito em suas campanhas.

Já a observação de Mariz acerca das candidaturas femininas é bastante esclarecedora, posto que faz sentido um segmento com maior número de mulheres do que a média se sentir mais identificado com uma candidata. Mas, seguimos reforçando a ideia de associação familiar como modelo que se encaixa perfeitamente à visão de mundo evangélica, embora recorrente na política nacional. Uma ideia bastante comum no meio evangélico é a de "Família projeto de Deus", a qual vem se tornando um forte modelo de atuação política. Assim, contrariamente às demais relaçóes de parentesco existente na política nacional, onde predomina a relação pai e filho, nos meios evangélicos é cada vez mais comum uma relação marido e esposa, este primeiro ocupando lugar na hierarquia de sua denominaçáo.

Enfim, consideramos oportuna a reflexáo introduzida por Mariz acerca das categorias de pré-modernidade e modernidade relativamente ao campo religioso em geral e no Brasil em particular. Igualmente, apreciamos a convincente análise realizada por Carranza sobre a consolidação do modus operandi político dos evangélicos e sua produção de uma inflexão no histórico estilo católico de atuar na esfera política, com destaque para a sua parcela carismática. Não menos importante é a análise realizada por Tadvald sobre as principais tendências observadas nas relaçóes entre religiáo e política no Brasil, resultantes de anos de pesquisas por ele conduzidas e que encontram eco em nossas próprias observaçóes e análises. E por derradeiro, retomamos uma observação, já referida, presente em todos os comentários, acerca da adoção de identidades genéricas de "evangélico" e "cristáo". Não se pode descartar a estratégia política de ampliar as possibilidades eleitorais quando um candidato não se vincula a nenhum segmento religioso, ideia que se sustenta principalmente no fato de uma parte destes candidatos estarem associados a pequenas denominaçóes pentecostais autônomas, que só atingem uma 
votação expressiva ao se unirem a um número maior de denominações, assim como a identificação entre o projeto evangélico e católico sob a categoria cristão. No entanto, também gostaríamos de salientar, como apontaram os comentaristas, o crescimento no campo evangélico de um pertencimento mais difuso e não-denominacional, parece ser análogo ou acompanhando outro fenômeno mais geral do fortalecimento da identidade evangélica, a saber de cultura gospel.

Recebido em: 31/10/2017 Aprovado em: 31/10/2017 
ARTIGOS 



\title{
ANTROPOLOGIA E FILOSOFIA POLÍTICA: UMA RELAÇÃO ESTRANHA? OU COMO ANALISAR CONTROVÉRSIAS ENTRE CIDADÃOS SECULARES E RELIGIOSOS EM UMA DEMOCRACIA LIBERAL
}

\author{
Cleonardo Mauricio Junior ${ }^{1}$ \\ Roberta B. C. Campos ${ }^{2}$ \\ Eduardo Henrique Gusmão ${ }^{3}$
}

Resumo: Levando em consideração a presença constante da religião nos dilemas do século XXI, questionamos neste artigo como deve se dar a análise dos eventos que póem em rota de colisão as identidades religiosas e seculares no seio das democracias liberais. Reconhecendo que o tema em questão tem sido objeto privilegiado da Filosofia Política, pretendemos nos perguntar até onde a Antropologia, que sempre privilegiou a descrição etnográfica como modo privilegiado de conhecimento, deve acompanhar uma ciência abertamente normativa no intuito de dar conta dos inúmeros conflitos envolvendo a religiáo na esfera pública. Ao transpormos os termos da comparação feita por Joel Robbins entre a Antropologia e a Teologia para a nossa contraposição com a Filosofia Política, pretendemos mostrar como a Antropologia Brasileira tem assumido contornos normativos em detrimento da autorreflexáo ao encarar os dilemas de abordar o fenômeno religioso na esfera pública diante das transformaçôes que a disciplina enfrenta.

Palavras-chave: Religião; Controvérsias; Antropologia; Filosofia Política; Reflexividade.

1 Doutorando no Programa de Pós-Graduação em Antropologia da Universidade Federal de Pernambuco. E-mail: cleonardobarros@gmail.com

$2 \mathrm{PhD}$ em Antropologia pela University of Saint Andrews. Professora Associada II do Departamento de Museologia e Antropologia da Universidade Federal de Pernambuco e do Programa de Pós-Graduação em Antropologia da mesma universidade. E-mail: robertabivar@gmail.com

3 Doutor em Antropologia pela Universidade Federal de Pernambuco. Professor Adjunto III do departamento de Psicologia da Universidade Federal de Campina Grande. E-mail: eduardo.henrique@ufcg.edu.br 


\begin{abstract}
Taking into consideration the constant presence of religion in the dilemmas of the twenty-first century, we question in this article how the analysis of events that collide religious and secular identities within liberal democracies should be analyzed. Recognizing that the subject in question has been a privileged object of Political Philosophy, we want to ask ourselves how far Anthropology, which has always privileged ethnographic description as a mode of knowledge, must follow an openly normative science in order to deal with the numerous conflicts involving religion in the public sphere. As we transpose the terms of Joel Robbins' comparison between anthropology and theology for our contraposition to political philosophy, we intend to show how Brazilian anthropology has assumed normative contours to the detriment of self-reflection in addressing the dilemmas of approaching the religious phenomenon in the public sphere before the transformations that the discipline faces.
\end{abstract}

Keywords: Religion; Controversies; Anthropology; Political Philosophy; Reflexivity. 
No século XXI, discussóes e debates que tomam a religião como problema parecem ocupar todos os lugares. Artigos de jornais, documentários, grupos de discussão on-line, blogs, cada um destes espaços e veículos de comunicação, na sua específica esfera de atuação, busca transmitir a história ou narrativa mais envolvente e atual sobre a questão religiosa. São frequentes, por exemplo, relatos que associam a religiáo com atos de violência ou exploração. No tocante a esse aspecto, a consideração de que atitudes motivadas religiosamente precisam ser levadas mais a sério, pelo fato da sua possível associação com ideologias e açóes extremistas, é uma das expressóes mais repetidas atualmente, seja em universidades ou em redaçóes de jornais.

Compreensivelmente, os episódios relacionados ao 11/09 deram voz e destaque a argumentos desta natureza. Nomes da ciência e da cultura como Richard Dawkins, Sam Harris, Christopher Hitchens, entre outros, estão entre aqueles cujas consideraçóes denunciaram os riscos para o estilo de vida das sociedades ocidentais advindos de comunidades religiosas e defenderam a mecânica relação entre religião e arcaísmo, fé e sectarismo, crença e violência. Pares, portanto, que compóem as pautas de inúmeros programas e debates no mundo contemporâneo.

Um olhar mais atento sobre essas questóes, no entanto, revela o quão estreito e seletivo é o foco, seja midiático ou acadêmico, muitas vezes dirigido ao fenômeno religioso e temas correlatos. De um ponto de vista metodológico, não se costuma reconhecer, ou perceber, a diversidade intrínseca às manifestaçôes de um fenômeno social como a religião. Ora, se as expectativas acerca da modernização e do consequente desaparecimento da religião revelaram-se ingênuas, é porque o referido fenômeno, em diferentes fases da modernidade, adquiriu complexidade e relevância. Logo, se há talvez algum consenso no que diz respeito à religiáo, é que ela está em todos os lugares.

É, portanto, na direção dessa constante presença da religião nos dilemas e conflitos do século XXI que pretendemos apontar o foco neste trabalho. Tomamos como ponto de partida a constatação já levantada por Casanova (1994) de que nas sociedades europeias ocidentais, no seio das quais o moderno processo de secularização se desenrolou, a religião não foi mantida 
nos limites da esfera privada, muito pelo contrário, conseguiu ir além dos tradicionais marcos impostos pelo cuidado pastoral, alcançando a vida pública e apresentando-se como um ator cultural capaz de desafiar forças políticas e sociais dominantes. Tendo em mente justamente as implicaçôes que envolvem a atuação dos segmentos religiosos da sociedade como atores públicos, nos perguntamos: como devemos analisar os debates públicos acerca de temas controversos e que póem em rota de colisão as identidades religiosas e seculares no seio das democracias liberais? Estamos interessados também em refletir sobre em que medida a Filosofia Política, que tem se debruçado sobre essa questão já há algum tempo, pode juntar-se às Ciências Sociais, e, em nosso caso específico, à Antropologia, em um esforço de cooperação para que se dê conta dos inúmeros conflitos envolvendo a religião na esfera pública. Em suma, queremos discutir, do ponto de vista da Antropologia, os limites desse diálogo com a Filosofia Política. Colocando de outra maneira, nos perguntamos: qual seria a contribuição específica da Antropologia para esse debate?

Nossas ponderações giram em torno das análises desenvolvidas por três autores: Charles Taylor, Jürgen Habermas e Talal Asad. Seus escritos propóem reavaliaçóes da modernidade que vão ao encontro da proposta deste artigo. Seja no minucioso e extenso estudo desenvolvido por Taylor sobre os sentidos e o alcance da modernidade secular em sociedades ocidentais, nas distintas fases da reflexão de Habermas sobre a questão religiosa, ou na crítica genealógica de Asad dirigida ao universalismo das categorias formadoras do secularismo moderno, esses três autores, em síntese, compartilham a preocupação com a presença da religião na esfera pública de sociedades marcadas pelo pluralismo religioso e cultural. Após dedicarmos uma seção a cada um dos referidos autores, colocaremos suas perspectivas em contraste a fim de iluminarmos pontos que podem contribuir para uma análise mais profunda dos conflitos envolvendo a religião na esfera pública, mais precisamente o caso brasileiro, atualmente marcado pela disputa da moralidade pública entre as igrejas pentecostais e os movimentos por direitos sexuais e reprodutivos. Outros analistas brasileiros já se debruçaram sobre os autores 
que discutiremos neste artigo, seja para apresentá-los brevemente ao público nacional (Reinhardt; Dullo, 2011, em uma apresentação de Asad), apontar as transformaçôes nos modelos analíticos (Dullo, 2012; Montero, 2012) identificando limites e dilemas da abordagem antropológica (Montero, 2012), discutir mais a fundo temas que serão levantados aqui (Araújo, 1996 para a discussão sobre Habermas e a religião; Araújo; Martinez; Pereira, 2012 a respeito de Taylor, Habermas e o Secularismo), ou para empreender um esforço comparativo com outros autores (Montero, 2010 para uma crítica de Asad a Geertz; Giumbelli, 2011 para um diálogo “imaginado” entre Asad e Bruno Latour), ou ainda apontar como esses autores poderiam contribuir para a Antropologia (Montero, 2009 para uma contribuição habermasiana sobre o tema da religião na esfera pública). Nosso enfoque, porém, é partir de um contraste entre as obras desses três autores como forma de lançar luz sobre os conflitos envolvendo cidadáos religiosos e cidadãos seculares acerca de temas controversos, pretendendo também, a partir de um diálogo entre diferentes tradiçóes epistemológicas, neste caso, a Filosofia Política e a Antropologia, apontar as contribuiçóes específicas desta última para o debate.

Dessa forma, nos parece interessante indagar até onde uma ciência abertamente normativa, como a Filosofia Política, pode nos ajudar com os casos concretos de embates públicos entre cidadãos religiosos e seculares com os quais temos nos deparado em nossas análises. Dito de outro modo: Até onde devemos seguir esses autores que propóem uma solução normativa para um campo em conflito? Não se trata aqui de descartarmos as contribuiçôes de Taylor e Habermas, muito caras a compreensão mais aprofundada da relação entre a religião, o secular e a democracia liberal. Mas é imperativo que enfrentemos de forma mais reflexiva a questão da transformação da Antropologia, tendo por foco os estudos das religióes. Paula Montero (2012) considera esgotada a forma clássica de como os antropólogos se situam no campo teórico, i.e como especialistas da alteridade. Na sua visão, é preciso levar em conta as novas condiçóes do fazer antropológico, evitando a reificação ontológica das visóes de mundo, inadvertidamente produzida enquanto se pensava apenas descrever e analisar, sem cair na armadilha da 
normatização do campo. Já para Joel Robbins (2006), a antropologia falha por ter perdido justamente a alteridade como centralidade na imaginaçáo teórico-metodológica. Ao cotejar Antropologia e Teologia, Robbins reconhece nessa relação uma situação embaraçosa (an awkward relationship), surpreendentemente, para a primeira, na medida em que a Teologia dá o tratamento à alteridade que, segundo ele, aponta uma direção para a qual a Antropologia precisa voltar-se novamente. Faremos uso, assim, da reflexão de Robbins como inspiração para contrapormos Antropologia e Filosofia Política, tentando mostrar como a Antropologia Brasileira (especialmente), deixou para trás aspectos presentes no cerne da herança antropológica ao encarar os dilemas de abordar o fenômeno religioso na esfera pública em face às transformaçóes que a disciplina enfrenta.

Sendo assim, apresentaremos no desenvolver deste artigo, primeiramente, as contribuiçôes dos três autores: Taylor, Habermas e Asad; Em seguida, faremos um contraponto que deixa os trabalhos de Taylor e Habermas de um lado e, do outro, a Antropologia do Secularismo de Talal Asad. Nesse momento, traremos também à discussão algumas reflexões presentes no trabalho de Saba Mahmood $(2001,2009)$ a fim de reforçarmos nosso argumento a respeito da estranheza da relação entre uma ciência tradicionalmente normativa e outra que estabelece seus fundamentos na descrição em detrimento do arbitramento. Por fim, faremos a discussão sobre os limites do diálogo da Antropologia com a Filosofia Moral tomando como base, como dissemos, o trabalho de Joel Robbins (2006), logrando avançar no enfrentamento da transformação do fazer antropológico e seus dilemas analíticos na questão religião e democracia.

TAYLOR E A MORAL SECULAR COMO CONDIÇÃO DO PLURALISMO

Podemos afirmar, em termos gerais, que a preocupação de Taylor nas obras As Fontes do Self(1997) e Uma Era Secular (2010) é erguer um painel 
interpretativo capaz de mostrar como a modernidade secular pode ser compreendida como um mundo moral. Ao assumir o propósito de articular e elaborar uma história da identidade moderna, situada no intervalo temporal que segue do século XVI em diante, Taylor problematiza as mudanças ocorridas não como processos que teriam se desenvolvido em bases epistêmicas ou institucionais neutras, mas como experiências com fundamentos morais e espirituais.

Taylor, nos livros mencionados, problematiza dois significados geralmente associados à noção de secularização, ambos de natureza negativa. $\mathrm{O}$ primeiro concebe a secularização como o declínio das crenças e práticas religiosas; o segundo trata esse processo como equivalente à saída da religiáo da esfera pública. Às duas concepçôes correspondem explicações sobre a forma como o processo de secularização se desenrola na modernidade. De um lado, o declínio da fé seria o motor que dá força à secularização. Como consequência imediata desse processo teríamos o desaparecimento da religião dos espaços públicos. A outra possibilidade explicativa reverte essa relação: seria a marginalização da religião na vida social o fator que ampliaria o ocaso da fé individual. Se ao lado da primeira explicação teríamos a ciência como a principal força a tornar a crença religiosa problemática, a segunda perspectiva, ao enfatizar a saída da religião da esfera pública, traria como causa principal da secularização as mudanças institucionais provocadas pela modernidade.

Ora, Charles Taylor diverge de ambos os entendimentos. E ao fazê-lo, afasta-se das relaçóes causais que tomam o avanço da ciência como recurso explicativo exclusivo para a compreensão da dinâmica histórica da secularização. Primeiro, Taylor reconhece as contribuiçôes advindas da própria religião para o processo de secularização e o quanto de natureza religiosa os movimentos de laicizaçáo ocorridos no Ocidente possuem. Para isso o autor aponta como, a partir da Reforma e da feição assumida pelo Cristianismo do século XVI em diante, mediaçóes externas passaram a ser rejeitadas e o compromisso interior do crente ganha relevância, tornando-se o espaço da relação individual com Deus (Taylor, 2010). Para Taylor, mais do que qualquer coisa, a passagem para uma época de descrença ocorre devido ao 
150 Cleonardo Mauricio Junior, Roberta B. C. Campos, Eduardo Henrique Gusmão

apelo moral incontornável que determinadas configurações passam a exercer sobre a vida das pessoas. A ciência, portanto, longe de ter o monopólio do processo, faz companhia a outras fontes morais alternativas na composição de um cenário responsável por tornar a fé uma esfera problemática, sujeita a questionamentos.

Sendo assim, seguindo Taylor, o processo pelo qual a razão científica se consolida como modelo de compreensão do mundo tem a ver, acima de tudo, com a concepção de sujeito engendrada a partir de uma nova perspectiva moral. Essa concepção estaria firmada sobre uma ética da crença, que recomenda cautela e dúvida diante da realidade de experiências e eventos carentes de evidências (Taylor, 1997, p. 518). Taylor salienta ainda que uma das principais consequências da identidade moderna (baseada na ética da crença) foi a obtenção de certo ganho epistêmico (Taylor, 1997, p. 405), obtido a partir do advento de diferentes fontes morais, o que colocou princípios éticos até então inquestionáveis em contato com uma situação de pluralismo e abertura a outras possibilidades de posicionamento no mundo. Assim, é possível dizer que, para Taylor, uma época secular é aquela na qual o enriquecimento moral individual se desenvolve para além dos limites impostos por fronteiras religiosas ou teístas.

A partir daí Taylor irá identificar as tendências culturais que, em momentos distintos radicalizam posicionamentos sobre o modo como alguém deve realizar-se e expressar-se individualmente: uma expressão distinta do individualismo clássico e em oposição a discursos que prescrevem adaptaçôes a recomendaçóes externas ao indivíduo ou em conformidade com modelos de comportamento inspirados em discursos religiosos ou políticos. São movimentos de natureza democrática que irão dar força a uma ética da auto-orientação, a qual, por sua vez, facilitará o reconhecimento, da parte de diversas sociedades ocidentais, da importância de agendas políticas multiculturais. Neste cenário, o destaque que o multiculturalismo irá obter a partir da segunda metade do século XX, bem como a ampliação do alcance de um individualismo que não leva em consideração objetivos que ultrapassem os limites da realização humana, serão dois desdobramentos 
da modernidade secular. Se as religióes e principalmente o cristianismo precisam traduzir suas mensagens numa linguagem que ultrapasse os limites litúrgicos e formais, Taylor reconhece que isto se dá em decorrência da época atual ser marcada por dinâmicas e imagens como religiáo mínima, crença sem pertencimento, busca, espiritualidade, entre outras configuraçóes que compartilham uma mudança de imaginário social (Taylor, 2010, p. 210). Modificaçóes que recaem sobre o lugar ocupado pelo sagrado no imaginário de sociedades cujas disposiçôes são, cada vez mais, pós-durkheimianas, visto que a experiência ou o vínculo com o sagrado deixam de ser construídos em contato exclusivo com instituiçôes religiosas, e passam a ser definidos pelas preferências individuais.

Baseando-se nas explanaçóes de Taylor para respondermos a pergunta motivo deste artigo (como deve ocorrer o debate público entre cidadãos religiosos e seculares em espaços democráticos?), podemos afirmar que, a partir deste autor, teríamos as condiçóes epistêmicas para um debate democrático engendradas nesse processo de modernização aqui apresentado. Ou seja, os atributos indispensáveis ao debate democrático são decorrentes justamente do ganho epistêmico ocasionado pelo processo de secularizaçáo. A ética da crença e da auto-orientação, a horizontalização da vida social e a espiritualidade em torno da busca pela realização individual, ao possibilitarem a crítica dos pontos de vista últimos, sustentariam o debate democrático entre aqueles que são diferentes, fortalecendo as ferramentas do reconhecimento mútuo. Essa nova ordem moral teria possibilitado enfim, que vivêssemos no mundo do overlapping consensus rawlsiano, no qual diferentes grupos estariam aptos a concretizar acordos sobre temas públicos a partir de pontos de vista distintos.

Se Taylor elenca as potencialidades surgidas para tal em meio a uma nova ordem moral, ele não parece, no entanto, dar respostas concretas sobre como se deve proceder com esta deliberação democrática entre diferentes. Uma pergunta, portanto, permanece sem resposta: como deve ser o processo de construção de um consenso entre diferentes? 


\section{HABERMAS E O PROCESSO \\ DE APRENDIZAGEM COMPLEMENTAR}

Jürgen Habermas tem tentado responder essa questão mais diretamente. Em seu entendimento, o próprio processo de deliberação democrática seria responsável por aguçar as sensibilidades necessárias à busca de consensos. $\mathrm{O}$ que Habermas recomenda é o engajamento de cidadãos religiosos e seculares em um "processo de aprendizagem complementar" (Habermas, 2007b), a fim de que seja possível o diálogo e o alcance de objetivos comuns.

Antes de explicar como esse processo de aprendizagem funcionaria, é importante enquadrá-lo nas mudanças de entendimento de Habermas quanto à secularização e o papel das tradiçóes religiosas na esfera pública. Em um primeiro momento, Habermas concebe o religioso como uma atitude que justificaria uma realidade alienante, impedindo o homem de alcançar a liberdade. Essa só seria obtida quando sua busca se desvencilhasse do controle da metafísica, o que, por sua vez, só ocorreria a partir do momento em que se recorresse à racionalidade comunicacional, uma esfera cujos limites seriam marcadamente seculares e eticamente responsáveis (Habermas, 1987). Porém, já ao final da década de 1980, Habermas modifica a sua compreensão diante do fenômeno religioso, passando a reconhecê-lo como uma necessidade existencial. Deixando para trás as referências ao desaparecimento da religiáo, ele passa a enfatizar o processo de privatizaçâo da questáo religiosa, salientando a importância dos recursos explicativos oferecidos por dimensôes como a fé diante de experiências marcadas pela impossibilidade de compreensão. É a década de 1990 com os seus impactos decorrentes da expansão do capitalismo e do avanço da ciência que o leva a reconhecer a impossibilidade das questóes relacionadas à vida em sociedade serem resolvidas com a mediação exclusiva das razóes seculares.

A mudança mais significativa no pensamento habermasiano acerca do lugar da religião na esfera pública vem à tona no início do século XXI. O novo século traz consigo um desafio metodológico abraçado por Habermas: reconhecer a crescente relevância pública da religião. Vivemos, agora, ele 
afirma, em um mundo pós-secular (Habermas, 2002). Com isso, Habermas não quer dizer apenas que a religião conseguiu manter-se viva em meio a um ambiente cada vez mais secularizado. Nem que nos limitemos a reconhecer publicamente sua contribuição quanto à reprodução de motivos e atitudes. Para Habermas, na verdade, a expressão "pós-secular" se refere à possibilidade de comunicação entre as razóes secular e religiosa a respeito dos conteúdos de verdade que definem cada uma. Essa comunicação assumiria a forma de um processo comum de aprendizagem complementar (Habermas, 2007b, p. 52).

Essa proposta acerca da forma como cidadáos seculares e religiosos devem se relacionar diverge das explanaçóes anteriores de John Rawls sobre um dos princípios fundantes do Estado liberal: o de que todo debate democrático deve estar baseado em argumentos acessíveis a todas as pessoas, tornando possível a comunicação de princípios e condutas particulares entre grupos distintos (Habermas, 2007a, p. 137-138). A fim de cumprir esse princípio, Rawls havia estabelecido uma exigência (proviso) quanto ao uso público de argumentos não públicos nos debates democráticos - as doutrinas totalizantes (religiosas ou não) precisariam apresentar, na discussão pública, argumentos políticos apropriados e não razóes exclusivamente oriundas de suas visóes de mundo. Habermas, por sua vez, considera que essa imposição repercute de maneira assimétrica nas vidas dos cidadãos religiosos e seculares (Habermas, 2007a, p. 137-138). Não se pode esperar, diz Habermas, que todos os crentes fundamentem seus posicionamentos políticos deixando de lado suas convicçóes religiosas. Sendo o Estado liberal democrático considerado o protetor, de igual modo, de todas as formas religiosas de vida, não pode, portanto, obrigar "os cidadãos religiosos a levarem a cabo, na esfera pública política, uma separação estrita entre argumentos religiosos e não-religiosos quando, aos olhos deles, esta tarefa pode constituir um ataque à sua identidade pessoal" (Habermas, 2007a, p. 147).

O que fazer, então? São duas as soluções de Habermas para este dilema: primeiro, mesmo reconhecendo que o Estado democrático liberal não pode exigir uma "sobrecarga mental e psicológica insuportável para seus cidadãos religiosos” (Habermas, 2007a, p. 147), Habermas não anula o proviso rawl- 
siano, mas o desloca para o âmbito institucional. Em outras palavras, as opiniōes religiosas poderiam ser colocadas sem a necessidade de tradução no âmbito da esfera pública informal. A partir desta nova orientação, a barreira da traduçáo surgiria somente diante do limiar institucional.

A segunda solução habermasiana para anular a assimetria presente na relação entre cidadãos religiosos e seculares na esfera liberal democrática seria entender este trabalho de tradução como uma tarefa cooperativa. Caberia aos cidadãos seculares, portanto, uma participação ativa neste processo de tradução do religioso para a razão pública. Se aos cidadãos religiosos impóe-se o fardo da tradução de seus argumentos a fim de que se viabilize sua participação na esfera institucional, tal carga seria compensada, afirma Habermas, "pela expectativa normativa segundo a qual os cidadáos seculares se abrem a um possível conteúdo de verdade de contribuiçóes religiosas" (Habermas, 2007a, p. 147). Essa abertura possibilitaria, assim, um diálogo no qual "as razóes religiosas podem, eventualmente, aparecer como argumentos acessíveis em geral" (Habermas, 2007a, p. 149-150). Assim, diz ainda Habermas, o processo de secularização passa a ser compreendido como um processo comum de aprendizagem complementar, no qual ambos os lados estarão em condiçôes de levar a sério em público, por razóes cognitivas, as respectivas contribuições para temas controversos (Habermas, 2007b, p. 52).

\section{ASAD E O SECULARISMO COMO DOUTRINA POLÍTICA E REGIME DE SENSIBILIDADES}

Se Taylor e Habermas apostam, respectivamente, no ganho epistêmico da modernidade e no processo de aprendizagem duplo para estabelecer as bases de um debate democrático entre diferentes concepçóes de mundo e, mais especificamente no que diz respeito ao nosso objeto de análise, entre cidadáos seculares e religiosos, Talal Asad é bem menos esperançoso quanto à possibilidade de resultados igualitários advindos da esfera pública liberal. Em Formations of the Secular: Christianity, Islam, Modernity (2003, 
doravante Formations) o expediente de Asad é o da crítica contundente à intrincada relação entre secularismo e o capitalismo liberal democrático dos estados-nação (ver Cannell, 2010 e Dullo, 2012 para uma revisão sobre a Antropologia do Secularismo). O objetivo principal de Formations é, portanto, questionar a relação entre o secular como categoria epistêmica e o secularismo como doutrina política, com foco na questão do Islã em território europeu.

A premissa básica de Asad é, assim, mostrar como o secularismo vem a ser mais do que a simples exigência de separação entre a religião e as instituições do Estado. Exemplos dessa separação, afirma Asad, poderiam ser encontrados já na cristandade medieval e nos impérios islâmicos. O que haveria de verdadeiramente peculiar no secularismo ocidental é a maneira como ele serve, na companhia de outras instituiçôes (como o consumismo, a indústria, os direitos humanos, entre outros), para o sustento do projeto de modernidade, ou como Asad prefere dizer, para a manutenção de "uma série de projetos interligados que certas pessoas no poder visam colocar em prática” (Asad, 2003, p. 13, tradução nossa).

No que diz respeito ao objetivo principal deste texto, qual seja, o debate acerca de questôes de interesse nacional em uma esfera pública plural, Asad o aborda logo na introdução de Formations. Ali, dialoga diretamente com as consideraçôes de Taylor acerca de como esta nova ordem moral possibilitou que vivêssemos no mundo do overlapping consensus rawlsiano, onde diferentes grupos, diante de questóes que dizem respeito ao bem comum, estariam aptos a deixarem para trás suas razóes privadas alinhando-se em torno de uma razão pública, ou uma ética secular, transcendente. No entanto, um dilema acompanha o debate na esfera pública, e o próprio Taylor reconhece, lembra Asad, que as disputas em torno do que deve ser definido como razão pública e não pública não cessarão em uma democracia liberal plural. Se a aposta de Taylor para a resolução destas contendas inevitáveis recorre à persuasáo e à negociaçáo, Asad diverge ao salientar o quanto os mecanismos que diferenciam as razóes públicas e privadas são arbitrários. Estes, destaca o autor (Asad, 2003, p. 6), são postos em movimento pelo 
156 Cleonardo Mauricio Junior, Roberta B. C. Campos, Eduardo Henrique Gusmão

Estado e suas instâncias jurídicas, os quais, diante da impossibilidade do alcance de consensos, recorrem à violência como uma expressão legítima e necessária da força estatal.

Nesse quadro, se o que podemos chamar de mito de origem do secularismo o apresenta como responsável pelo fim da violência resultante das guerras religiosas, Asad aponta o que de fato aconteceu: uma mera substituição das guerras religiosas pela violência das guerras nacionais e coloniais. Apesar disto, a narrativa que deposita sobre as ideologias religiosas os motivos dos atos de violência e intolerância continua embasando os discursos que visam prevenir a entrada da religião na esfera pública.

São as sensibilidades que Asad nomeia de seculares as encarregadas pela perpetuação e sustentação do discurso que imputa às ideologias religiosas a responsabilidade por atos de violência e intolerância na esfera pública. Para refutar essa narrativa, cuja principal decorrência é o nivelamento entre religião e violência, ele afirma, bastaria lembrar os "inúmeros agentes seculares que tem perpetrado atos de grande crueldade" (Asad, 2003, p. 12 , tradução nossa). No entanto, para Asad, o mais interessante, ao invés de comparar a crueldade dos regimes seculares e religiosos, seria "analisar como as sensibilidades morais relativas à inflição deliberada de dor têm sido formadas na sociedade secular moderna” (Asad, 2011, p. 164). Em outras palavras, Asad está interessado em como as sensibilidades relativas à dor e à crueldade contribuíram para o estabelecimento de uma narrativa de superação da religião e consolidação de regimes seculares e, ao mesmo tempo, capitalistas.

E como agem essas sensibilidades? Enquanto, por exemplo, um dos paradigmas da ideologia secularista consiste na narrativa da eliminação da dor "gratuita" promovida pela religiáo contra os corpos das pessoas, as dores infligidas nas populaçôes das colônias do sistema imperialista eram consideradas "necessárias". Esse sofrimento fazia parte do inevitável processo de "humanização" de certas populações. Condená-los por seus costumes bárbaros e cruéis, portanto, estaria na pauta das dores aceitáveis pelas sensibilidades seculares, ao passo que as dores "desnecessárias", como 
o autoflagelo praticado em rituais religiosos dos nativos, seriam cruéis e desumanas. Enfim, as sensibilidades morais seculares aprovam certas dores, as que são geradas no processo de se tornar plenamente humano (de acordo com os padrôes morais ocidentais) e repudiam outras, colocando as dores repudiadas sob a rubrica do fanatismo religioso, portanto desnecessárias e desumanas (Asad, 2011).

Diante das colocaçóes de Asad, poderíamos concluir que o secularismo constitui-se em um mecanismo através dos qual o Estado busca manter os símbolos e sensibilidades necessários à construção de sua "personalidade". A própria noção de esfera pública, devedora do secularismo, não escapa de sua crítica: ao invés de consistir em um espaço de debate político, ela se revela como uma rede de conexóes emocionais que sustenta a imagem do cidadáo ideal (daquele Estado-nação específico, Asad, 2005, p. 50). Sendo assim, ainda que Asad não revele minuciosamente os mecanismos que constroem as sensibilidades seculares nos mesmos moldes com que expóe os modos de produção de discursos autoritativos na religião (ver Asad, 2010), ele nos oferece um instrumental para apontarmos as contradiçóes inerentes ao secularismo, iluminando as sensibilidades que o sustentam, possibilitando o desenvolvimento de uma crítica profunda dos binarismos (público-privado, secular-religioso, etc.) que pautam a relação entre religião, esfera pública e democracia liberal.

\section{FILOSOFIA POLÍTICA E ANTROPOLOGIA: UMA RELAÇÃO ESTRANHA?}

Após analisarmos os pontos de vista dos autores apresentados até aqui, parece inevitável apontarmos uma contraposição entre, de um lado, Taylor e Habermas e, do outro, Talal Asad (mesmo considerando as diferenças entre as abordagens dos dois primeiros). Não é preciso uma investigação pormenorizada para percebermos que o modus operandi da Filosofia Política dos primeiros trata a questão de uma maneira diferente da Antropologia 
de Asad. Enquanto a Filosofia é marcada por uma discussão normativa, não se eximindo de estabelecer parâmetros para uma situação de conflito, a Antropologia concebe seu modo de fazer a partir, primeiro, da descrição e depois do questionamento da pretensa universalidade das categorias que alimentam a contenda. Assim, ao invés de definir o modo como deve ser o debate na esfera pública entre crentes e cidadãos seculares, o fazer antropológico coloca sob escrutínio as próprias noçóes que informam o conflito, a exemplo das ideias de religiáo, crença, cidadania, laicidade, esfera pública, entre outras concepçôes que comunicam as gramáticas morais de vários dilemas da contemporaneidade.

De um lado, então, vimos Taylor e Habermas evidenciando tanto as virtudes requeridas quanto os modos necessários à promoção de um debate público que se desenrole com razoabilidade. $\mathrm{O}$ primeiro nos apresenta o advento na era secular das potencialidades responsáveis pela sustentação do debate democrático. Em sua narrativa, o surgimento de fontes morais alternativas abriu espaço para o alcance de consensos entre visóes de mundo divergentes. Impulsionados por uma ética da crença, os indivíduos tornaramse aptos a colocar em questâo seus pertencimentos e pontos de vista últimos, possibilitando o alcance do consenso sobreposto. Para Habermas, por sua vez, a fim de que ocorra a traduçáo de conteúdos religiosos para a razáo pública, de modo a se legitimar a participaçáo da religiâo na esfera política, é necessária a construçáo de uma nova mentalidade em torno da cidadania entre os envolvidos nos debates públicos. Enquanto dos cidadãos religiosos é cobrado deixarem suas crenças para trás ao cruzarem os umbrais das instituiçóes públicas, aos cidadãos seculares outorga-se o papel de cooperadores nesse processo. Com a ressalva de que os cidadáos seculares estejam abertos de antemão às contribuiçôes da religiáo para o debate público, eles estariam aptos a auxiliar na tradução dos preceitos religiosos para a razáo pública.

Do outro lado, aprofundando as ideias de Talal Asad, podemos trazer ao debate as críticas da antropóloga Saba Mahmood $(2001,2009)$ às resoluçôes de Taylor e Habermas, a fim de reforçar nosso argumento a respeito das diferenças de abordagem entre a Antropologia e a Filosofia Política. 
Ao modo tradicional da Antropologia, ou seja, baseando-se em um caso etnográfico, Mahmood mostra como esse detachment que ganha o status de virtude democrática nos trabalhos de Taylor, possibilitando o consenso sobreposto, e de Habermas, dando a possibilidade de se deixar para trás preceitos religiosos diante das instituiçóes públicas, é uma invenção do Ocidente, e da moral secular, que arbitrariamente define a forma ideal de religião (baseada no conceito de crença) e de cidadão (baseado no conceito de autonomia). No caso dos eventos que se sucederam à publicação das charges dinamarquesas representando Maomé, por exemplo, Mahmood (2009) mostra como as análises que consideraram exageradas as reaçóes de ultraje de muitos muçulmanos diante da publicação trazem à tona as implicações de se outorgar o estatuto de crença à religiáo na modernidade. Invoca-se, nesse caso, uma ideologia semiótica que estabelece a separação entre símbolos e ícones religiosos de um lado, e as figuras sagradas do outro. Tomar uns pelos outros revelaria, assim, uma falha em compreender que símbolos são arbitrariamente ligados ao que os seres humanos entendem como sagrado (o símbolo em questão é tão somente uma representação e não contém o sagrado em si mesmo). Mahmood mostra como esse tipo de compreensão empobrecida das imagens, dos ícones e dos signos ignora as práticas afetivas e incorporadas que ligam um sujeito a um determinado símbolo. No caso da participaçáo de mulheres de camadas médias em movimentos de avivamento islâmico, por sua vez, Mahmood (2001) aponta as consequências metodológicas de se transpor automaticamente uma noção de agência baseada na tradição liberal para a análise de mulheres envolvidas em tradiçôes religiosas patriarcais. Esta noção de agência como sinônimo de autonomia - "a capacidade de se realizar o seu próprio interesse contra o peso dos costumes da tradiçáo, da vontade transcendental ou de outros obstáculos (sejam eles individuais ou coletivos)" (Mahmood, 2001, p. 206, tradução nossa) - limitaria o entendimento sobre a vida de mulheres cujos desejos, afetos e vontades têm sido moldados por tradiçóes não liberais.

Diante do exposto, é possível afirmar que a relação entre uma ciência abertamente normativa e outra que se constitui a partir da discussão do 
potencial ameaçador dos juízos de valor compartilharia da mesma estranheza (awkwardness) verificada por Joel Robbins (2006) na contraposição da Antropologia com outro paradigma: o teológico. $\mathrm{O}$ incômodo na relação entre Teologia e Antropologia, diz Robbins, viria do embaraço causado pelo fato de cada uma delas alcançar com relativa facilidade algo que, apesar do esforço empreendido, geralmente escapa à outra. Resumindo o argumento de Robbins, os antropólogos teriam facilidade para relatar com eficácia seu encontro com a alteridade, sendo bem sucedidos, ainda, em mostrar como esses diferentes modos de viver não seriam inventados. No entanto, a dificuldade estaria em dar um passo adiante com relação ao propósito de sua agenda crítica: convencer as pessoas que essa alteridade tem algo a nos ensinar. Já a dificuldade enfrentada pelos teólogos estaria na tentativa de persuadir seus leitores a aceitarem que outras visóes de mundo são reais (ou, pelo menos, válidas). Por outro lado, eles estariam prontos a zombar do esforço empregado pelos antropólogos em fazer com que seu público "morda a isca e permita que estas diferenças mudem suas vidas" (Robbins, 2006, p. 288, tradução nossa). Replicando o raciocínio de Robbins desta vez na contraposição da Antropologia com a Filosofia Política, arriscamos dizer que os filósofos encontrariam elementos para zombar dos antropólogos diante das barreiras que estes encontram na tentativa de enquadrar os fenômenos que estudam em um horizonte normativo. "Treinado para exorcizar o fantasma do preconceito em qualquer de suas manifestaçôes", como diz Roberto Cardoso de Oliveira (1996, p. 52), o antropólogo encontraria a resistência da tradição que o ensinou a expurgar o etnocentrismo ao tentar atravessar o limiar entre a análise do que é e do que deve ser.

No entanto, ao nos debruçarmos sobre o caso brasileiro, cujo cenário político encontra-se marcado por uma disputa pela moralidade pública entre movimentos sociais que reivindicam direitos sexuais e reprodutivos de um lado e, do outro, os líderes de igrejas pentecostais, as ciências sociais, especialmente a Antropologia, aparentam estar encerradas em contornos normativos aos modos da Filosofia Política, ignorando as dimensóes mais reflexivas. Coloca-se diante de nós um caso paradigmático no qual, também 
arriscamos dizer, os antropólogos brasileiros parecem invejar os colegas desobrigados da resistência de uma tradição que privilegia a descrição etnográfica em detrimento do arbitramento. Com uma diferença: Se a Filosofia aborda sem rodeios seus dilemas a partir da ótica do dever-ser, a Antropologia, por sua vez, parece desconsiderar o peso normativo subjacente às categorias (discurso de ódio, fundamentalismo, extremismo, etc.) que tem lhe servido de base nesse contexto de conflito envolvendo o pentecostalismo na esfera pública brasileira.

Com isso surge diante de nós uma pergunta inevitável: considerando, como vimos, o deslocamento de perspectiva posto em prática nos trabalhos de Asad e Mahmood a partir da Antropologia do Secularismo - em uma tentativa de dar conta das implicaçóes que envolvem a relação de cidadáos muçulmanos com as maiores democracias liberais do mundo - por que ainda não é possível perceber a contento o mesmo deslocamento quando se trata do pentecostalismo no Brasil? Para nós, na medida em que são analisados na sua relação com naçôes que infligiram danos ao Oriente Médio com seus projetos imperialistas, os muçulmanos assumem o papel de refugiados ou migrantes, traduzindo-se em um exemplo perfeito do objeto privilegiado da atenção antropológica, nos dizeres de Robbins (2013), o suffering subject, ou seja, "o sujeito vivendo na dor, na pobreza, ou sob condiçôes de violência ou opressão” (p. 448, tradução nossa). Fica difícil, no entanto, encontrar um lugar para o pentecostalismo nessa narrativa que domina o modo corrente do fazer antropológico. A virtude incentivada no antropólogo para que este relate fielmente as vidas de seus sujeitos de pesquisa é que construa com eles um sentido de conexão, uma ligação empática. Se considerarmos que os pentecostais são opositores na esfera pública justamente dos sujeitos de pesquisa que permanecem como objeto privilegiado da atenção da antropologia brasileira (nossos suffering subjects), mais do que impossibilitar a referida ligação empática, sobra para os pentecostais nessa narrativa o papel definido por Susan Harding (1991) de o “outro repugnante”. Isto posto, não nos surpreendem, então, as dificuldades em refletir sobre as categorias utilizadas para dar conta do pentecostalismo. Essas dificuldades já foram 
apontadas por Mariz e Campos (2014), que mostraram como o impacto dos pentecostais na cultura brasileira é subestimado pelos cientistas sociais devido a questóes teóricas, metodológicas, e sobretudo ideológicas. Estas últimas diriam respeito a uma construção de uma ideia de cultura nacional, subjacente às análises, composta por uma matriz sincrética e identofágica de tudo o que seria estranho, como o pentecostalismo. Assim, "afirmar que o pentecostalismo não tem sucesso em mudar nossa cultura”, dizem as autoras, "corresponderia afirmar que fomos bem sucedidos resistindo à colonização de nossas consciências: somos fieis a nós mesmos" (Mariz e Campos, 2014, p. 204).

Dando continuidade a nosso argumento, é imprescindível ainda evocar o desafio proposto por Robbins (2006) à Antropologia como resultado da confrontação com a Teologia, uma vez que pretendemos nós mesmos lançar uma provocaçáo complementar à desse autor a partir do cotejamento com a Filosofia Política. Ao expor a contraposição feita pelo teólogo John Milbank (apud Robbins, 2006) entre o que ele define como a ontologia social subjacente a toda teoria social (uma ontologia da violência) e aquela para a qual a teologia deveria se voltar (uma ontologia da paz), Robbins quer apontar para algo deixado para trás por nós, antropólogos, e que Milbank nos teria lembrado: "a discussão sobre ontologias sociais alternativas pode avalizar argumentos críticos de grande força” (Robbins, 2006, p. 292, tradução nossa). Sendo assim, "é preciso comprometer-se novamente a encontrar alteridade real no mundo", reivindica Robbins (Robbins, 2006, p. 292, tradução nossa). Após nos resignarmos como antropólogos a "servir como testemunhas do horror no mundo" (Robbins, 2006, p. 292, tradução nossa), deveríamos aceitar o desafio de encontrar no mundo alteridades reais no nível da ontologia social. Náo como na Teologia, continua Robbins, devedora das premissas dos mitos cristãos. Precisamos, diz ele, "fundamentar as outras ontologias que trazemos à discussão da maneira que sempre fizemos - encontrando as pessoas que vivem em seus próprios termos e descrevendo como eles o fazem" (Robbins, 2006, p. 292, tradução nossa). Encontrar as pessoas que vivem em seus próprios termos e descrever como elas o fazem também deve 
ser uma das tarefas da Antropologia Brasileira quando se trata de analisar os debates públicos acerca de temas controversos e que póem em rota de colisão as identidades religiosas e seculares no seio das democracias liberais. Mas no contraste que propomos com a Filosofia Política avistamos ainda outra provocaçáo que, da mesma forma, procura reconduzir a Antropologia a mais um de seus fundamentos: a autorreflexão. Se se quer evitar arbitrariedades no plano normativo, é imprescindível a renovação do compromisso com a reflexividade do antropólogo diante de um campo onde se multiplicam dilemas morais nos quais o pesquisador está diretamente implicado. Enfim, a vocação crítica da Antropologia e a reflexividade do antropólogo não podem ser consideradas posiçóes mutuamente excludentes.

A atual tendência em proferir juízos de valor nas abordagens do fenômeno religioso das produçóes brasileiras acerca do pentecostalismo na esfera pública, produzindo estereótipos ao invés de evitá-los, não se explica somente pelas novas condiçóes do fazer antropológico, já bastante debatido e analisado na literatura pós-moderna, mas também pelo fato da Antropologia Brasileira tornar-se cada vez mais ativista e engajada. Se, por um lado, nesse processo de transformaçáo da disciplina, a Antropologia passa a ter papel cada vez mais importante nas transformaçóes sociais e na garantia de direitos humanos no que concerne aos direitos reprodutivos e LGBT, por outro, as análises parecem desconhecer ou não reconhecer o(a) antropólogo(a) ativista como ator nos embates, conflitos e controvérsias morais. Os pressupostos e categorias acionadas pela Antropologia ativista não são questionados, servindo apenas como referência de crítica dos outros atores sociais.

No entanto, é possível notar um movimento em direção à reflexão sobre o papel do(a) antropólogo(a) militante na construção do evangélico como o outro repugnante da Antropologia Brasileira. Regina Novaes (2017) se pergunta em trabalho recente, por exemplo, a quem interessam as generalizaçóes sobre os evangélicos. Ela admoesta pesquisadores e cidadãos a atentarem para as diferentes maneiras de ser evangélico, o que contribuiria, em seu modo de ver, para compreender o que chama de dissintonias entre os posicionamentos dos membros da Frente Parlamente Evangélica e o 
164 Cleonardo Mauricio Junior, Roberta B. C. Campos, Eduardo Henrique Gusmáo

conjunto das percepçóes de toda a população que os elege. Novaes faz ainda uma crítica contundente aos estudos que circunscrevem aos evangélicos "o mal da democracia", ignorando outros grupos sociais e econômicos beneficiados com a atuação dos parlamentares da bancada evangélica, e com isso "economizam reflexão sobre realidades interesses e disputas políticas presentes no Brasil de hoje". Além de evitar as generalizaçōes, é imprescindível colocar sob escrutínio as categorias que fazemos uso para dar conta das análises dos conflitos envolvendo os pentecostais na esfera pública brasileira, apontando seus limites, contradiçóes e peso normativo arbitrário. Começando com a própria noção de público e da subjacente ideia de que a religião contaminaria essa esfera com sua presença, nos moldes da coletânea sobre Religióes e Controvérsias Públicas, organizada por Paula Montero (2015): é preciso mostrar como a religião constrói e conforma a esfera pública a partir de determinadas disputas e agenciamentos, ao invés de medir e julgar sua presença nessa esfera. Dullo e Quintanilha (2015), por sua vez, propóemse a analisar as contradições da sensibilidade secular da política brasileira tendo como pano de fundo as eleiçôes presidenciais de 2014. Os autores mostram como uma declaração enunciada pela então candidata Dilma Rousseff em um culto evangélico afirmando ser "feliz a nação cujo Deus é o Senhor" não foi vista como uma ameaça ao Estado Laico, mas, ao contrário, foi entendida como uma estratégia de aproximação de setores evangélicos a fim de conquistar-lhes o voto, ao passo que o fato de Marina ser evangélica tê-la-ia colocado como um perigo à laicidade, mesmo a candidata não tendo acenado aos evangélicos da forma como Dilma Rousseff, que ganharia a eleição, o fez. Campos, Gusmão e Mauricio Junior (2015), analisando o debate entre Silas Malafaia e o deputado Jean Wyllys em uma sessão da Câmara sobre o projeto que ficou conhecido como "cura gay", constatam a incomensurabilidade dos conceitos de laicidade representados pelos debatedores e apontam as contradiçóes na fala do deputado na medida em que se depreende de seu discurso uma exclusão por antecipação da religião do debate público, ao mesmo tempo em que ele se empenha em promover o pluralismo de visóes de mundo como valor inerente à democracia liberal. Por 
fim, Peter Fry e Sergio Carrara (2016) questionam o apego de antropólogos a categorias essencialistas outrora superadas pela Antropologia na ocasião do embate entre, mais uma vez, o pastor Silas Malafaia e o geneticista Eli Vieira a respeito das causas genéticas da homossexualidade, após a polêmica entrevista concedida pelo pastor a um programa de televisão. Em comum, esses autores assumem o expediente de trazerem à tona a narrativa secularista de substituição progressiva do engano, que seria a religião, pela razão secular subjacente às análises das controvérsias envolvendo pentecostais na esfera pública brasileira, apontando, como diz Hirschkind (2011), a sensibilidade secular que contribui para esta narrativa progressiva e, mais ainda, a contribuição das ciências sociais, e aqui especialmente, da Antropologia, na consolidação dessa narrativa.

\section{CONSIDERAÇÕES FINAIS}

Após percorrermos as contribuições de autores chave no que diz respeito às implicaçôes do debate público entre cidadãos religiosos e cidadãos seculares para uma democracia liberal com pluralismo de valores e visóes de mundo, queremos ressaltar que não é nossa intenção apontar uma proeminência de nossa abordagem do tema, baseada na tradição antropológica, com relação às contribuiçóes da filosofia política para o debate em questão. Não se trata de forma alguma, portanto, de afirmar que os trabalhos de Taylor e Habermas sucumbiram à narrativa secularista de subsumir (ainda que inconscientemente) a religiáo ao domínio do privado ou de um modo de vida a ser superado progressivamente. Basta relembrar alguns conceitos trabalhados por esses autores como a noção habermasiana de sociedade pós-secular, que não se restringe ao simples reconhecimento da importância da dimensão da fé, mas se configura em um momento no qual se deve desenvolver um esforço cooperativo visando estabelecer parâmetros através dos quais consciências defasadas - pertencentes indistintamente a cidadáos seculares e religiosos - aprendam a debater na esfera pública; como também 
apontar a recusa de Taylor em aceitar a tese liberal que destaca uma suposta singularidade da religiáo: a de ser um resíduo de um modo de vida ainda não plenamente racional.

Nosso objetivo sempre foi, a partir da contraposição dessas diferentes formas de tratar do fenômeno aqui analisado, questionar como nós, cientistas sociais e, especialmente, antropólogos, podemos enriquecer nossas abordagens perguntando-nos, primeiro, sobre até onde uma episteme normativa pode contribuir para um modo de construir conhecimento que trabalha diretamente com contextos empíricos específicos, enfim, com a realidade sempre mais complexa e, por sua vez, inerentemente multiforme. A fim de superar a estranheza dessa relação, concluímos, é indispensável fomentar o diálogo com a Filosofia Política, mas fazê-lo em nossos termos, como diria Geertz (2001), examinando dragóes sem abominá-los ou domesticá-los.

No caso específico do panorama brasileiro sobre o qual discorremos até aqui, é necessário, por fim, reafirmar o compromisso com a reflexividade do antropólogo. Os ganhos que a Antropologia brasileira logrou acumular em sua face militante não podem nos levar a esquecer de implicar o antropólogo no mesmo horizonte epistemológico em que se investigam os sujeitos de pesquisa. Sem isso, a Antropologia perde a principal contribuição que pode dar ao debate sobre uma questáo tão cara às democracias liberais no mundo atual, a da presença da religião na esfera pública. 


\section{REFERÊNCIAS}

ARAÚJO, Luiz Bernardo Leite. Religião e Modernidade em Habermas. São Paulo: Loyola, 1996.

ARAÚJO, Luiz Bernardo Leite; MARTINEZ, Marcela Borges; PEREIRA, Taís Silva (Org.). Esfera Pública e Secularismo: Ensaios de Filosofia Política. Rio de Janeiro: Eduerj, 2012.

ASAD, Talal. Formations of the Secular: Christianity, Islam, Modernity. Stanford: Stanford University Press, 2003.

. Reflections on Laïcité and the Public Sphere. Items and Issues, New York, v. 5, n. 3, 2005.

- A construção da religião como uma categoria antropológica. Tradução de Bruno Reinhardt e Eduardo Dullo. Cadernos de Campo, São Paulo, n. 19, p. 263-284, 2010.

. Reflexôes sobre crueldade e tortura. Tradução de Bruno Reinhardt e Eduardo Dullo. Revista Pensata, Guarulhos, v. 1, n. 1, p. 164-187, 2011. CAMPOS, Roberta Bivar Carneiro; GUSMÃO, Eduardo Henrique Araújo de; MAURICIO JUNIOR, Cleonardo Gil de Barros. A disputa pela laicidade: uma análise das interaçôes discursivas entre Jean Wyllys e Silas Malafaia. Religiäo \& Sociedade, Rio de Janeiro, v. 35, n. 2, p. 165-188, 2015.

CANNELL, Fenella. The Anthropology of Secularism. Annual Review of Anthropology, Palo Alto, v. 39, p. 85-100, 2010.

CARDOSO DE OLIVEIRA, Roberto; CARDOSO DE OLIVEIRA, Luís R. Ensaios Antropológicos sobre Moral e Ética. Rio de Janeiro: Tempo Brasileiro, 1996.

CASANOVA, José. Public Religions in the Modern World. Chicago: University of Chicago Press, 1994. 
168 Cleonardo Mauricio Junior, Roberta B. C. Campos, Eduardo Henrique Gusmão

DULLO, Eduardo. Após a (Antropologia/Sociologia da) Religião, o Secularismo? Mana, Rio de Janeiro, v. 18, n. 2, p. 379-391, 2012.

DULLO, Eduardo; QUINTANILHA, Rafael. A sensibilidade secular da política brasileira. Debates do NER, Porto Alegre, ano 16, n. 27, p. 173-198, 2015.

FRY, Peter; CARRARA, Sérgio. "Se oriente, rapaz!”: onde ficam os antropólogos em relação a pastores, geneticistas e tantos "outros" na controvérsia sobre as causas da homossexualidade? Revista de Antropologia, São Paulo, v. 59, n. 1, p. 258-280, 2016.

GEERTZ, Clifford. Anti antirrelativismo. In: . Nova luz sobre a antropologia. Rio de Janeiro: Jorge Zahar, 2001.

GIUMBELLI, Emerson. A noção de crença e suas implicações para a modernidade: um diálogo imaginado entre Bruno Latour e Talal Asad. Horizontes Antropológicos, Porto Alegre, v. 17, n. 35, p. 327-356, 2011.

HABERMAS, Jürgen. The theory of communicative action: reason and the rationalization of society. Boston: Beacon Press, 1987.

2002.

A inclusão do outro: estudos de teoria política. São Paulo: Loyola,

- Religião na esfera pública: pressuposiçôes cognitivas para o "uso público da razão" de cidadãos seculares e religiosos. In: . Entre naturalismo e religiáo: estudos filosóficos. Rio de Janeiro: Tempo Brasileiro, 2007a. . Fundamentos pré-políticos do Estado de direito democrático? In: HABERMAS, Jürgen; RATZINGER, Joseph. Dialética da secularização: sobre razão e religião. Aparecida, SP: Ideias \& Letras, 2007 b.

HARDING, Susan. Representing fundamentalism: the problem of the repugnant cultural other. Social Research, New York, v. 58, n. 2, p. 373-393, 1991. HIRSCHKIND, Charles. Is there a secular body? Cultural Anthropology, v. 26, n. 4, p. 633-647, 2011. 
MAHMOOD, Saba. Feminist theory, embodiment, and the docile agent: some reflections on the Egyptian Islamic revival. Cultural Anthropology, v. 16, n. 2, p. 202-236, 2001.

. Religious Reason and Secular Affect: An Incommensurable Divide? In: ASAD, Talal et al. (Ed.). Is Critique Secular? Blasphemy, Injury, and Free Speech. Los Angeles: University of California Press, 2009. p. 64-100. (Townsend Papers in the Humanities, 2).

MARIZ, Cecília; CAMPOS, Roberta Bivar C. O pentecostalismo muda o Brasil? Um debate das ciências sociais brasileiras com a antropologia do cristianismo. In: SCOTT, Parry; CAMPOS, Roberta Bivar C.; PEREIRA, Fabiana. Rumos da Antropologia no Brasil e no mundo: geopolíticas disciplinares. Recife: Editora UFPE, 2014. p. 191-214.

MONTERO, Paula. Jürgen Habermas: religiáo, diversidade cultural e publicidade. Novos Estudos CEBRAP, São Paulo, n. 84, p. 199-213, jul. 2009.

MONTERO, Paula (Org.). Religiöes e controvérsias públicas: experiências, práticas sociais e discursos. Sáo Paulo: Editora Terceiro Nome; Campinas: Editora da Unicamp, 2015.

- Talal Asad: para uma crítica da teoria do símbolo na antropologia religiosa de Clifford Geertz. Cadernos de Campo, São Paulo, n. 19, p. 259-261, 2010.

. Controvérsias religiosas e esfera pública: repensando as religióes como discurso. Religião e Sociedade, Rio de Janeiro, v. 32, n. 1, p. 167-183, 2012. NOVAES, Regina. Os "evangélicos" e a política: reflexōes necessárias sobre o Brasil de hoje. Teoria \& Debate, Rio de Janeiro, ed. 158, 29 mar. 2017. Disponível em: <http://www.teoriaedebate.org.br/index.php?q=materias/politica/os-evangelicos-e-politica-reflexoes-necessarias-sobre-o-brasil-de-hoje> . Acesso em: 19 jul. 2017.

REINHARDT, Bruno; DULLO, Eduardo. Apresentação. Revista Pensata, Guarulhos, v. 1, n. 1, p. 160-163, 2011. 
170 Cleonardo Mauricio Junior, Roberta B. C. Campos, Eduardo Henrique Gusmão

ROBBINS, Joel. Anthropology and Theology: an awkward relationship? Anthropological Quarterly, Washington, DC, v. 79, n. 2, p. 285-294, 2006. . Beyond the suffering subject: toward an anthropology of the good. Journal of the Royal Anthropological Institute, London, v. 19, n. 3, p. 447-462, 2013.

TAYLOR, Charles. As fontes do self: a construção da identidade moderna. São Paulo: Edições Loyola, 1997. . Uma era secular. São Leopoldo: Editora UNISINOS, 2010.

Recebido em: 22/04/2017 Aprovado em: 20/09/2017 


\title{
EXPERIÊNCIA E CONHECIMENTO VIVIDO NO TERREIRO: ASPECTOS DA UMBANDA DE PAI JOAQUIM ${ }^{1}$
}

\author{
Lucas Gonçalves Brito
}

Resumo: Durante pesquisa de campo etnográfica, pude registrar que os filhos de Oxalá da Casa de Pai Joaquim concebem a Umbanda como uma religiáo-ciência. Asseveram também que grande parte de seu conhecimento não está nos livros, pois é adquirido por meio da experiência cotidiana, com os pés descalços, dentro do terreiro. A partir dessa hipótese, busco esboçar algumas relaçóes entre a epistemologia da umbanda de Pai Joaquim e a experiência vivida. Deste modo, extraio o conhecimento vivido por meio de três narrativas, as quais se inserem no escopo de uma teoria nativa da mediunidade, do desenvolvimento mediúnico e do processo mediúnico. Uma das conclusóes é de que a abordagem das umbandas enquanto epistemes pode consistir em uma alternativa teórico-metodológica à reiterada perspectiva sociológica que acompanhou o estudo do tema.

Palavras-chave: Umbanda; Experiência Vivida; Mediunidade; Conhecimento Umbandista.

1 Este artigo é uma versão atualizada de alguns excertos do que, em minha dissertação de Mestrado, constituía o terceiro capítulo. Agradeço às pessoas que contribuíram, direta ou indiretamente, para a produção do texto - dentre elas, Izabela Tamaso e Luis Felipe Kojima Hirano -, bem como aos pareceristas.

2 Mestre em Antropologia Social pelo PPGAS/UFG e doutorando em Antropologia Social pelo PPGAS/UFRGS. E-mail: lucasgb25@gmail.com 


\begin{abstract}
During my ethnographic field research, I registered that the "filhos de Oxalá da Casa de Pai Joaquim" conceive Umbanda as a "science-religion". The people assert that large amount of their knowledge is not found in books, but rather acquired through their day-to-day experience inside the temple, with bare feet. From this hyphotesis, I try to outline some relations between the epistemology of Pai Joaquim's umbanda and the lived experience. Therefore, I will extract lived knowledge by means of three narratives, which are inserted within the native theory concerning mediumship, mediumistic development and mediumistic process. One of the conclusions is that the approach of umbandas as epistemes could provide an alternative both theoretical and methodological to the reiterated sociological perspective which has accompanied the study topic.
\end{abstract}

Keywords: Umbanda; Lived Experience; Mediumship; Umbandista Knowledge. 


\section{INTRODUÇÃO}

Para os filhos de Oxalá da casa de Pai Joaquim³, há um conhecimento que não está nos livros e que é transmitido por meio do cotidiano de trabalho no Centro, através da intuição e pelos contatos mediúnicos; em uma palavra, através da experiência.

O conhecimento corporificado e vivido é um dos aspectos de uma questão mais ampla que surgiu durante a pesquisa de campo desenvolvida junto ao Centro Espiritualista de Umbanda Pai Joaquim de Angola, em Goiânia, Goiás: lá, as pessoas não consideram Umbanda somente religião, mas também uma ciência. Tal religião-ciência, segundo o que me diziam, integra a arte, a filosofia, a magia e a religião e dá-se a esta síntese o nome de Umbanda.

Esta concepção endógena me conduziu a considerar a umbanda de Pai Joaquim como uma episteme, mas também como uma epistemologia. Ora, as pessoas, reflexivas, além de viverem, elaborarem e pensarem - não exatamente nesta ordem - as técnicas e concepçóes umbandistas, apresentam uma (meta)linguagem cujo conteúdo é o próprio conhecimento.

Tal concepção de Umbanda enquanto conhecimento colide o pressuposto evolucionista de hierarquizaçáo entre magia, ciência e religiáo para colocá-las em um mesmo plano e, deste modo, a umbanda de Pai Joaquim surge como uma epistemologia híbrida. Há, na Casa de Pai Joaquim, uma busca pela síntese de linguagens distintas sobre as coisas e seres do mundo e isso vai na contramão da fragmentação ocasionada pelo pensamento moderno, afeito a separar os saberes em áreas homogêneas e monolíticas. Lembro-me que, durante um ano de pesquisa de campo, em certos momentos,

3 A categoria êmica "filhos de Oxalá da Casa de Pai Joaquim" é usada no Centro para se referir a todas e todos filiados. Para indicar o lugar em que acontecem os ritos, as pessoas dizem ora "Casa de Pai Joaquim", ora "Centro" e ambas categorias aparecerão no decorrer deste texto. O termo "umbanda de Pai Joaquim" é usado pelas pessoas para classificarem a modalidade de Umbanda que praticam e, neste artigo, refere-se também à epistemologia nativa. 
causava-me surpresa algumas das inúmeras palestras assistidas. No curso de um mesmo ciclo de palestras - chamadas Portal do Céu, requisito para qualquer pessoa que quisesse trabalhar como médium no Centro - havia temas tão diversos como física quântica, magia, magnetismo, esoterismo, história da Umbanda e psicologia.

A abordagem da umbanda de Pai Joaquim enquanto conhecimento fornece um caminho teórico-metodológico alternativo aos eixos analíticos centrados na questão das origens. Diversos estudos enfocaram os aspectos sociais e históricos do que se convencionou chamar "período de formação da Umbanda”, cuja delimitação estaria ligada aos processos de transformação do Brasil na passagem do século XIX para o XX; tais como a Abolição da escravatura, a Proclamação da República, a emergência de uma economia capitalista, a industrialização, o "sentimento nacional" do Estado Novo e o embranquecimento das expressóes culturais negras ${ }^{4}$. Parece evidente que muito já foi dito sobre isso e o objetivo aqui não será revisar bibliograficamente tais inúmeras e valiosas linhas.

Tomando a umbanda de Pai Joaquim como epistemologia, este texto consiste em um esboço de antropologia da experiência com o objetivo de extrair da experiência o conhecimento vivido. Partirei da proposição de que, ao contrário de outros conceitos, a categoria "experiência" é algo peculiar ao modo de produção do conhecimento antropológico (Turner, 1985). Se é impossível viver a mesma experiência dos outros, e há quem diga que isso não é ao menos desejável, a solução que se abre é a descrição e exegese das expressóes da experiência. Tendo a narrativa sido a expressão escolhida, a relação intersubjetiva que permeia a exegese não configura uma relação de tipo "eu-isso", mas uma relação "eu-tu” (Turner, 1985).

4 Ver Magnani (1986); Bastide (1989); Negrão (1993); Isaia (1999); Ortiz (1999); Belmont (2007); Nogueira (2009); Giumbelli (2010); Sá Junior (2012) e Costa (2013). Apesar dos distintos contextos de pesquisa, tais autores e autora abordam, ora explícita ou menos diretamente, o que tenho chamado de paradigma teórico de busca por origens.

Debates do NER, Porto Alegre, ANo i 8, N. 32, P. I7I-20 I, JUl./DeZ. 20 I 7 
A escolha dessa forma de apresentação do material etnográfico se deve a que etnografia não é aqui considerada simplesmente um método, mas também uma "relação melodiosa" em que o etnógrafo procura ajustar o diapasão e vibrar em sintonia com as pessoas. Etnografia, nesse sentido, requer "atenção generosa, profundidade relacional e sensibilidade ao contexto" (Ingold, 2014, p. 384, tradução nossa). Estar no mesmo plano, horizontalmente, com os interlocutores, evoca o esforço de exercício da coetaneidade, pois "se a ascendência - o elevar-se em uma posição hierárquica - está excluída, as suas relaçóes devem se dar num mesmo plano: elas serão frontais" (Fabian, 2013, p. 179). A isso chamei humildade epistemológica - a posição do pesquisador que busca eliminar os sentidos de hierarquia e de colonialidade do saber que são evocados quando acontece o encontro etnográfico e/ou a relação entre conhecimento acadêmico e conhecimento nativo.

Há, na singeleza das narrativas, algumas características que poderiam ter-me levado a considerá-las performances - aspectos como ruptura no fluxo contínuo da vida cotidiana, reflexão sobre o vivido, experiência intensificada, comunicação e transformação de conhecimento, audiência do pesquisador receptivo no processo de comunicação (função fática da linguagem) e relevo do conteúdo da narrativa (função poética da linguagem) (Hartmann, 2011; Langdon, 2007, 2011). Como diria Schechner (2006, p. 38, tradução nossa), "não existe nada inerente a uma ação nela mesma que a transforme numa performance ou que a desqualifique de ser uma performance". Prefiro, pois, tomar essas narrativas simplesmente como expressóes da experiência vivida. Pode-se dizer que o objeto aqui é a experiência e o conhecimento aprendido através da experiência; o que me permitiu alcançá-lo foi a narrativa e, esta, por sua vez, propiciou às pessoas refletirem e organizarem a experiência vivida (Erlebnis).

As narrativas foram induzidas por algumas perguntas como "O que te levou ao Centro?"; "Como você chegou ao Centro?"; "O que você sente quando está no terreiro e conversa com o preto-velho?" e "O que seu guia espiritual te ensina?”. Com exceção do texto de Tia Maria, as entrevistas foram gravadas em áudio, transcritas e minimamente reorganizadas, no 
sentido do recorte de trechos os quais as pessoas não se sentiriam à vontade em ver divulgados. Também houve inserção de algumas alteraçôes sintáticas (organização de frases) e palavras que articulam os trechos, sem prejuízo do conteúdo e significados das falas das pessoas. Em alguns trechos foram mantidas as perguntas que precediam as respostas, explicitando o diálogo entre quem narrava e o pesquisador.

Embora haja nas narrativas certa nuance poética, a preocupação aqui náo foi conferir aos textos todos os mecanismos de oralidade das pessoas/ narradoras, como Hartmann (2011) fez, até mesmo porque, não obstante a autorização livre e esclarecida, algumas pessoas/narradoras quiseram demonstrar a expectativa de que os elementos eminentemente orais seriam de algum modo formalizados.

Na sequência, encontrar-se-á narrativas de três médiuns da Casa de Pai Joaquim. As experiências e o conhecimento aprendido através delas sáo vinculados ao quadro da epistemologia nativa. Porém, antes, parece-me necessária a delimitação do que estou tomando por experiência.

\section{O CONCEITO DE EXPERIÊNCIA VIVIDA}

Para Desjarlais (1997), um dos problemas metodológicos com que os antropólogos se defrontam ao trabalhar com o termo "experiência" é que ele muitas vezes foi usado sem uma definição mais rígida.

Embora a experiência se constitua de elementos da inteligência e elementos afetivos, esses últimos foram convencionalmente preteridos. Lévy-Bruhl (2014) sublinhou que a noçáo de experiência, contudo, teria sido elaborada desde a antiguidade clássica, o que salienta o racionalismo que comumente marca a sua definição:

O papel essencial da experiência, tal como essa tradição a descreve e analisa, depois de Platão e seus predecessores até Kant e seus sucessores, é o de informar o sujeito senciente e pensante sobre as propriedades dos seres e objetos com os quais ela o póe em relação; de lhe fazer perceber os movimentos, os choques, 
os sons, as cores, as formas, os odores, etc.; o de permitir ao espírito humano refletir sobre os dados e sobre suas condições e o de construir uma representação do mundo. A noção geral da experiência que assim se desenvolve é "cognitiva" (Lévy-Bruhl, 2014, p. 5, tradução nossa).

De um ponto de vista diametralmente oposto, Bruner (1986a) e Turner (1985) conceituam a experiência enquanto um processo. Aqui temos uma tentativa contemporânea de coadunar os elementos afetivos e cognitivos da experiência. Retomando Dewey, Turner salienta que a experiência tem uma iniciação e uma consumação (expressão). Soma-se a isso a noção de Dilthey, segundo a qual a experiência é processada através de etapas distinguíveis, as quais envolvem "uma totalidade de repertório vital humano, constituído de pensamento, vontade e sentimento" a que Dilthey chamou de "estrutura de experiência” (Turner, 1986, p. 35, tradução nossa).

Derivado da hermenêutica de Dilthey, o conceito de Bruner e Turner opera uma distinção entre a simples experiência e uma experiência - Erlebnis. A primeira refere-se ao modo como cada pessoa recebe os dados sensórios e os interpreta por meio de processos mentais ou "como eventos são recebidos pela consciência” (Bruner, 1986a, p. 4, tradução nossa). A segunda diz respeito à "articulação intersubjetiva da experiência, a qual tem um começo e um fim e que então se transforma em expressão" (Bruner, 1986a, p. 6, tradução nossa).

Tal concepção transcende um dualismo estrito entre sensação e intelecção; entre percepção e cognição. Esse é um elemento teórico fundamental para a reflexão sobre a experiência vivida das pessoas com as quais dialoguei.

Estou interessado especialmente nas Erlebnisse, ou seja, as experiências que formam unidades de sentido e que tenham importância específica na vida das pessoas que as narram, a tal ponto de tornarem-se relevantes para serem expressas, consumadas, objetificadas. E é através da expressão a outras pessoas que a mera experiência se transforma em uma experiência (Turner, 1986). 
Como disse um filho da Casa em uma palestra no dia de desenvolvimento mediúnico: "Como a Umbanda não tem codificação, grande parte de nossas liçóes vem com a experiência". A abordagem da experiência no terreiro empreendida aqui diz respeito especialmente ao que sentem as pessoas durante os rituais, contudo, a experiência é um processo mais amplo que envolve pensamento, sentimento, ação, reflexão. $\mathrm{O}$ conhecimento que se aprende pela experiência é um aprendizado da pessoa inteira. Não é somente aprendizado da cabeça, mas também do coração.

O "desenvolvimento mediúnico" figura não só como um meio de educação da própria mediunidade, mas também como formação no sentido mais lato 5 . Essa educação da mediunidade poderia ser compreendida como um rito iniciático paulatino, cuja duração é relativa a cada médium e que se desenrola durante o tempo necessário à criação de um "vínculo fluídico" entre guia espiritual e a pessoa.

Quando os médiuns estabelecem a "sintonia" com os mentores e guias, aprendem a "receber" ou "captar" um conhecimento transmitido vibratoriamente pelos seres do plano astral aos seres do plano físico. Embora os filhos de Oxalá da casa de Pai Joaquim concordem que os processos mediúnicos são o que há de esotérico no Centro, no sentido de que não podem ser "vistos", "tocados", de modo tangível, náo definem a umbanda de Pai Joaquim como esotérica. Segundo Sr. Valério, dirigente do Centro, "o que tem de esotérico são as forças espirituais, as energias que se sente no lugar e os momentos nos quais alguém vê os espíritos através da clarividência" (notas de campo, 04/04/2016). Os efeitos desses processos causam profundas impressóes na consciência das pessoas, como poderemos verificar adiante através das narrativas.

5 A aprendizagem de técnicas e a "corporificação" de conhecimento ou habilidades, que não se limitam a conceitos apreendidos intelectualmente, poderiam também ser pensadas em termos de "educação da atenção" (Ingold, 2015). Para uma pesquisa que enfoca as habilidades imbricadas na prática da mediunidade, ver Bergo (2011).

Debates do NER, Porto Alegre, ANo i 8, N. 32, P. I7I-20I, JUl./DeZ. 20 I7 
Cada uma das narrativas traz a reflexão e interpretação da pessoa ao que viveu e não são aqui tomadas simplesmente enquanto dados a serem analisados. Neste sentido, os comentários que teço entre cada uma das narrativas têm como objetivo ressaltar e explicitar, nos termos da epistemologia nativa, o conhecimento aprendido pelas pessoas através da experiência, uma vez que considero as narrativas seguintes instrumentos metodológicos para registrar o conhecimento vivido.

\section{NARRATIVAS}

\section{Tia LAURINHA ${ }^{6}$}

Chovia muito naquela tarde de domingo. As ruas do bairro Crimeia Oeste estavam alagadas. Tia Laurinha procurava suas fotografias, guardadas entre os copos do armário da cozinha de seu antigo imóvel. Isso a auxiliaria a contar sua estória, coisas de cinquenta anos atrás. Afinal, quando chegou na Casa de Pai Joaquim, tinha mais ou menos vinte anos.

- Eu fui no Centro assim: eu fiquei doente, fiquei doente, sabe? E uma amiga minha falou assim... Eu ia na igreja e me sentia todinha dormente. Toda vida eu fui católica. Sentia todinha dormente. Foi uma amiga lá em casa. Não. Eu fui na casa dela, lá na rua 68 , cá embaixo. Cê não conhece Goiânia tudo não, né?

- A 68 lá no Centro da cidade? Conheço.

- É. Ela morava lá. Aí cheguei lá, ela falou assim: "Eu tô achando cê tão esquisita”. Porque fiquei meia passada, né? "Você tá?". "Tô”. E ela falou assim: "Tô frequentando um centro tão bacana, tão bom”. E eu tinha medo, morria de medo, sabe? Minha mãe, quando minha mãe era viva, eu era pequena ainda, tinha um compadre que chamava Francisco. Aí minha mãe ia lá... eu não sabia, mas eu lembro que era passe... dava passe na minha

6 Grande parte dos nomes são pseudônimos. Os nomes das pessoas que já "abandonaram" o corpo físico foram mantidos. 
mãe. E, como é que fala? Hoje a gente não pode pegar guia nenhum dentro de casa. Ele já era velho, né? Eu escondia de baixo da cama, mijava minha roupa todinha. Ele falou assim: "Olha, dona Umbelina, a senhora vai ter uma filha que vai ser médium de centro”. E não era eu? Eu morria de medo, tinha um medo dele. E aí fui crescendo, crescendo e fiquei doente. Eu não olhava assim mais, não enxergava as flores mais, era só pra baixo. Já tava criando uns caroços do lado de cá, assim. E uma amiga, Aparecida, falou assim: "Amanhã é segunda-feira, lá no Centro tem trabalho e nós vamo pra lá. Eu vou te levar lá”. Falei: "Não, vou de jeito nenhum!”. "Não, vai! Precisa ficar com medo não, cê vai". Falei: "Não gosto desses trem não". Eu tinha medo desse povo. Por causa desses centro que era violento, brabo. Porque tem uns centro que é brabo, né? E ela disse: "Não, esse não tem não. Conheço a mulher lá, ela é que dirige o trabalho". Aí nós fomos na segundafeira. Tia Maria tava trabalhando, ela trabalhava num quartinho. Aí Tia Maria veio, deu passe em mim. Tinha pouquinho médium, tinha médium nenhum quase. Deu passe... e nunca mais eu saí do Centro da Tia Maria. Nunca mais. Achei até bom, sabe? Aí depois já fui enxergando o verde, fui olhando pra cima, vendo os verde, sabe? Até que um dia, eu peguei logo meu guia porque eu já tava tão em cima pra ser média, né? Aí eu ia dormir e o guia vinha em mim e me fazia dar passe, sabe? O preto-velho Estrela d'Alva... me fazia dar passe nas pessoas. Minha mãe tinha uma amiga que não saía daqui de casa, ela era doente, né? Vinha da roça assim, em tempo de morrer, vinha pra ir no médico. O preto-velho descia em mim, dava o passe nela, ela ficava boa, não precisava ir no médico. Depois ela voltava pra roça de novo. Aí eu perguntei pra Tia Maria: "Tia Maria, eu tô assim, assim, assim. Desce o guia em mim e faz eu dar passe". Ela disse: "Não, minha filha, é assim mesmo. Você é mais recente no Centro. Em casa, você não pode pegar essa carga, não. Pode vir carga pesada e você depois não sabe..." Como é que a gente fala?

- Não sabe lidar? Não sabe limpar depois?!

-É. Pois é. Ela falou desse jeito pra mim. Aí depois eu fui acompanhando ela. Onde que ela ia, eu tava junto com ela. A gente trabalhava muito na 
pecuária, sabe? Tia Maria levantava 4 horas da madrugada, fazia as empadas pra gente vender lá na exposição agropecuária. Ela fazia as empadas e a gente fazia o jantar. Acho que ela falava "As coroas de Goiás". Que a gente era muita, que ajudava, né? Agora não tá nem metade de difícil de fazer as coisas.

- A senhora chegou no Centro, como a senhora tava dizendo, com vinte anos, mais ou menos, e aí a senhora tava com sintomas, sintomas de mediunidade mesmo, né?

- Acho que era. Sofri muito pra... sofri muito náo! Porque eu nem desenvolvi. Nem fui no terreiro fazer igual aquele povo lá.

- Foi natural, né?

- Foi natural. Aí tem uma parte mais bonita ainda. Quando eu comecei a ser médium, um dia, deitei e vi as guias, as sete guia, direitinho, em cima da minha cama, as guia, coisa mais linda. Não tinha guia esse tempo, depois que eu fui arrumar as guia, né? Por isso que eu tenho aquele tanto de guia no pescoço. Não sei se cê já viu.

- Como que era o momento que a senhora entrou, não sei se a senhora pode falar, se vai lembrar, quando a senhora entrou no Centro, tinha algum ritual pra começar a trabalhar? Ou náo teve isso? Uma reza, uma benzeção especial quando a senhora começou a trabalhar no Centro?

- Tinha a Tia Maria, que era a cabeça do Centro. Ela dava passe, ela me orientava. Falava como que era. Orientava. Eu não pego só preto-velho, não. Eu pego caboclo, pego as crianças, pego Yemanjá. Vem quase todos em mim. É que eu não gosto de demonstrar muito.

A narrativa de Tia Laurinha demonstra alguns aspectos da história do Centro e todo esforço e sacrifício dos pioneiros. Tia Laurinha, como se vê, chegou no Centro quando ele ainda funcionava no barracão que Tia Maria, a fundadora, tinha nos fundos de casa. Tendo acompanhado toda a peregrinação de lugar em lugar, Tia Laurinha lembrou, saudosamente, o tempo em que foi construído o Centro no terreno doado pelo entáo prefeito da cidade. 
Entre pedras, panelas e sofrimento, o trabalho dos pioneiros era coletivo. Foi através do braço de cada um e através da venda de comida na exposição agropecuária de Goiânia que angariaram os recursos para a construção do Centro. O trabalho como experiência corporificada é também um aspecto do conhecimento vivido, pois está intimamente ligada à noção de pessoa na umbanda de Pai Joaquim: considera-se a/o médium uma pessoa que "precisa trabalhar". Este trabalho envolve o auxílio em atividades práticas do Centro, mas também é um trabalho interno, calcado no autoconhecimento, que garante à/ao médium cumprir diligentemente sua tarefa.

Tia Laurinha conta que desde pequena teve contato com técnicas de passe e transe, pois um compadre de sua mãe era adepto de práticas espirituais e foi através desse senhor que Tia Laurinha veio a saber, anos antes, que seria "médium de Centro". Mesmo conhecendo premonitoriamente seu destino, Tia Laurinha continuou amedrontada com as práticas do compadre de sua mãe. Na realidade, foi através da dor que Tia Laurinha chegou ao Centro.

Muitos filhos de Oxalá da Casa de Pai Joaquim - em palestras, conversas e nas narrativas de Tia Maria e Vitória - citam o papel do sofrimento físico para a tomada de consciência quanto à responsabilidade de ser médium. Isto porque, na teoria nativa, a mediunidade é uma escolha prévia do espírito reencarnante. Antes de (re)encarnar, a pessoa prepara uma espécie de roteiro que lhe pontua os eventos principais da vida que entấo se inicia, sendo a mediunidade um aprendizado do serviço desinteressado ao próximo e também um modo de reparar erros cometidos em vidas passadas. Como "quem colhe planta", cada pensamento, palavra e ação engendra no futuro da pessoa responsabilidades que a mantém presa ao ciclo de reencarnaçóes. O "dom" da/o médium é a faculdade de sentir as vibraçóes mais sutis que circundam o espaço, de forma que isso lhe possibilite compreender a eternidade da vida e perceber que a matéria, o corpo físico e o que lhe é inerente são apenas um aspecto da existência. A percepção das leis divinas e a abertura a outras realidades corresponde à "evolução espiritual".

Toda pessoa tem a capacidade de sentir vibraçóes espirituais, mas médiuns, em decorrência de alguma causa anterior - como, por exemplo, 
ter sido uma "sinhâ" cruel aos seus escravos em uma vida anterior - estão "destinados" e têm a responsabilidade de servir de veículo dos seres intangíveis para auxiliar outras pessoas a evoluírem e, no mesmo lance, ajudarem a si mesmos, limpando sua "ficha cármica".

Como a/o médium é sensível às vibrações espirituais, é necessário a educação mediúnica, que propicia o equilíbrio. A/o médium que chega no Centro doente é, na verdade, uma pessoa que precisa aprender a lidar com as forças espirituais que sente de modo demasiado agudo. E é através dessa busca de equilíbrio que muitos médiuns descobrem - ou melhor, "lembram" - a tarefa a que estão "destinados".

Guimarães (1992) sustentou que, no terreiro estudado por ela, o desenvolvimento mediúnico e a educação do transe configuravam uma espécie de terapia e que a própria Umbanda seria um ritual terapêutico. A autora afirmou que "a mediunidade é a experiência espiritual da Umbanda por excelência” (Guimarães, 1992, p. 75). E se mediunidade é a via de acesso à Espiritualidade, então “o corpo é sempre tido como um 'aparelho' para que as forças espirituais possam se expressar” (Guimarães, 1992, p. 76).

Tia Laurinha conta que não havia curso de desenvolvimento mediúnico como acontece hoje na Casa de Pai Joaquim e, neste sentido, para ela o desabrochar de sua faculdade mediúnica "foi natural". Entretanto, isto não quer dizer que não havia, em seu cotidiano vivido, o cultivo de uma relação educativa entre ela e seu guia espiritual, o preto-velho Estrela d'Alva. Quando Tia Laurinha começou a ter contato com seu guia espiritual, ele transmitia as vibraçóes dele e fazia com que tinha Laurinha, receptiva a isso, "desse passe" nas pessoas. Tia Laurinha, em sua humildade, logo aprendeu que não se deve "pegar guia" em casa, isto é, não é permitido "incorporar" ou ter essa espécie de intercâmbio mediúnico em lugar inapropriado, fora do Centro, porque a Casa de Pai Joaquim protege os médiuns. Sendo o cosmos permeado de seres intangíveis, há aqueles que buscam atrapalhar o desenvolvimento dos médiuns ou até mesmo se passar pelos genuínos guias espirituais, confundindo e distorcendo o conteúdo das mensagens do plano astral. 
Como se pode observar através da narrativa de Tia Laurinha, no ato da narração, há certa relação intricada entre presente e passado, que não necessariamente se dá de modo linear. A pessoa pode muito bem começar sua narrativa in media res (no meio dos acontecimentos) ou até mesmo começar do "fim".

Apesar de apresentar-se linear e fixa, a narrativa é aberta. A própria estrutura da narrativa a constrange à sistematização por meio de sequências, quando o tempo parece experienciado sequencialmente (Bruner, 1986b). A narrativa, articulando presente (contexto atual) e passado (memória), pode ser considerada o final, a consumação, a expressão de uma estrutura da experiência, Erlebnis. Essa estrutura de experiência configura um processo de interpretação e de atribuição de significado ao vivido.

A experiência vivida é um processo que se estrutura através de cinco momentos: 1) o prazer ou a dor, relativos a uma situação, são sentidos mais intensamente do que nos comportamentos repetitivos e rotineiros; 2) imagens de experiências passadas são evocadas com clareza; 3) os sentimentos originalmente atados aos eventos passados são revividos; 4) o significado é gerado pela reflexão sobre as interconexóes entre os eventos passados e presentes e 5) a experiência se completa através da expressão, da sua comunicação de modo inteligível aos outros - e assim, torna-se uma experiência (Turner, 1982).

O que fiz foi somente traduzir a narrativa de Tia Laurinha - enquanto expressão de sua Erlebnis - nos termos mais gerais da epistemologia da umbanda de Pai Joaquim. A premissa do aprendizado pela dor e do aprendizado pelo amor se repetirão na narrativa de Tia Maria e na narrativa de Vitória.

\section{TIA Maria}

"Muitas lágrimas, muitas dores, mas venci”. Foi assim que Tia Maria, fundadora do Centro, definiu sua jornada. Respondia, solícita e atenciosa, o que lhe perguntava o pesquisador. Estávamos no galpão, um espaço no 
terreno do Centro, usado para festividades. Era dia de festa junina, tradiçâo da Casa desde o início. Os trabalhadores do Centro estavam arrumando alguns detalhes e as pessoas convidadas ainda não haviam chegado. Ali, sentada à mesa, em frente a barraquinha na qual, dentro em breve, ela iria vender tapetes, panos de prato e delicados enfeites para porta, em forma de pomba, como ela disse, representando o Divino. Tia Maria, que era "uma católica apostólica romana de fita no pescoço", recebeu uma missão inimaginada - fundar um Centro de Umbanda em Goiânia. Não obstante ela fosse sobrinha de Dr. Colombino Bastos, um dos fundadores de uma das primeiras casas de Umbanda da cidade de que se tem notícia, a Tenda Irmãos do Caminho, nunca pensou que teria a responsabilidade de dirigir ela mesma um templo. Nos idos dos anos 60, Tia Maria, adoentada de moléstia renal, não encontrava solução para o problema na medicina alopática. Uma sua prima de Niterói a levou para um tratamento espiritual no Centro Espiritualista de Umbanda Pai Joaquim de Aruanda. Lá, Tia Maria recebeu, das mãos de Pai Joaquim de Aruanda, a sua tarefa. Jaubert Cândido e Silva, dirigente do Centro de Niterói, veio a Goiânia e, junto com Pai Joaquim de Aruanda, passou o cajado para Tia Maria. A primeira incorporaçáo de Pai Joaquim de Angola com sua médium renitente, tornou-se inolvidável. Tia Maria sentiu nojo quando percebeu que, de seu nariz, saía uma secreção estranha. Ela achava que não tinha merecimento, até hoje, disse ela, acha que não tem. Pai Joaquim de Angola falou: "Você não é nada, a partir de agora você é meu cavalinho e vai seguir o que eu mandar”. A partir desse momento começou sua peregrinação. Ela teria que realizar a Sessão das Almas uma vez por semana, mas não tinha um lugar. Em um dia 8 de dezembro, tendo Nossa Senhora da Conceição como advogada, dirigiu-se ao prefeito Iris Resende. Tia Maria não lembra o que falou, mas o prefeito e os quatro vereadores que estavam com ele não contiveram o choro. Iris era afilhado do marido de uma mulher do círculo íntimo de Tia Maria e prometeu doar um terreno. Hoje, com um templo maior e um terreno com espaço 
ainda vazio, Tia Maria, sentada à mesa junto com esse jovem que a ouvia atenta e curiosamente, sorriu leve. $\mathrm{Na}$ sua maturidade firme e resoluta, ela foi sentar-se por detrás da banquinha, com seu xale roxo. Noite de junho, sem fogueira. $\mathrm{O}$ que aquece vem de dentro, vem de longe.

Como se vê, Tia Maria, fundadora do CEUPJA, também chegou à Umbanda através da dor. Dizem que a doença foi um processo conduzido pela Espiritualidade para levar Tia Maria ao encontro de sua missão.

Primeiramente, deve-se compreender que, na umbanda de Pai Joaquim, o termo Espiritualidade diz respeito aos seres intangíveis que habitam no plano suprassensível. Os guias espirituais das pessoas têm múltiplos meios de orientá-las nas encruzilhadas da vida e auxiliá-las em seus caminhos. Os guias não são escolhidos a torto e a direito; eles muitas vezes têm relaçôes anteriores, "cármicas", com seus protegidos. Tendo a pessoa-médium escolhido sua tarefa incomum antes mesmo de encarnar-se e seu corpo astral ajustado para afastar-se com mais facilidade do corpo físico, não seria menos lógico que os seres espirituais que a assistem também se irmanem a ela através de laços anteriores. Esses laços, às vezes milenares, entre protetor e protegido, impelem a ambos recobrarem situaçôes em que cometeram delitos e faltas contra si mesmos e contra alguma coletividade.

Assim como a/o médium tem responsabilidade em relação ao cumprimento desinteressado e leal de suas atividades, o guia espiritual também tem deveres em relação à/ao médium, pois o intercâmbio mediúnico depende de ambos para acontecer e é primeiramente a ambos que ele beneficia. É neste sentido que se pode compreender o recado de Pai Joaquim de Angola para Tia Maria durante a primeira incorporação: "Você não é nada, a partir de agora você é meu cavalinho e vai seguir o que eu mandar”. A/o médium renitente, ainda incompreensivo quanto à sua tarefa, precisa ser domado, como um "cavalo" (termo com o qual os umbandistas se referem aos médiuns). 
A peregrinação que os filhos de Oxalá empreenderam, procedendo com a sedimentação da Casa de Pai Joaquim, fundada em 1968, acabou quando Tia Maria recebeu a intuição de ir pedir ao prefeito de Goiânia um terreno. Tia Maria, que nunca deixou completamente o catolicismo - veja-se que o CEUPJA anualmente sempre organiza a Festa de Santos Reis e que Tia Maria, na festa junina, estava vendendo artefatos como a pomba, símbolo do Espírito Santo - pediu auxílio à Nossa Senhora da Conceição e falou algo que, segundo ela, arrancou lágrimas aos políticos.

Essa narrativa foi extraída de uma conversa ocorrida algum tempo antes dos convidados chegarem para a festa junina, no dia dezoito de junho de dois mil e dezesseis. Trabalhávamos todos na organização e pedi a Tia Maria que me contasse um pouco de sua experiência no Centro. É interessante notar que ela narrou suas experiências de modo sequencial e linear. A tarefa foi inscrever essas sequências no bloco de notas, articulando-as em um outro momento. Essa conversa pôde acontecer somente após quase um ano de pesquisa de campo, quando os filhos de Oxalá da casa de Pai Joaquim já estavam confiantemente tranquilos quanto à presença de um pesquisador entre eles.

\section{VITÓRIA}

Solícita e séria, Vitória, com um olhar meditativo, sentou-se na primeira fileira de bancos dentro do templo. Estar ali evocava respeito e sinceridade.

- Eu cheguei no Centro há dez anos atrás. Foi em março. Eu tive um problema alérgico. Eu mudei para Goiânia com dezessete anos e eu morava no "Parque da Poeira" em Brasília. Um lugar que não era asfaltado. Convivi com poeira a minha vida inteira e, quando eu mudei para cá, desenvolvi uma alergia à poeira. Isso era o diagnóstico dos médicos. Eu me coçava a apareciam feridas nas minhas pernas. Somente nas pernas. Coçavam e abriam feridas - era uma coisa absurda. Na fase boa da adolescência, passei por um momento bem complicadinho, uma fase difícil. Minha família sempre foi espírita; meu avô; meu bisavô era palestrante em centro; minha avó já 
frequentou e minha mãe é médium e trabalha desde muito nova. E eu sentia coisas, mas eu queria negar - eu náo queria. Não era algo que eu queria para $\mathrm{mim}$. Quando eu era criança eu tinha um tio que tinha umas manifestaçôes muito grotescas mesmo, ele se machucava. E aquilo me traumatizou muito e eu falava: "Eu não quero isso pra mim". Às vezes eu via um vulto. Uma vez eu acordei no quarto à noite com os meus avós. Meu avô eu conheci, o meu avô paterno, minha avó não. Eu acordei com um casal me olhando na ponta da minha cama. Eu olhei aquilo e fiquei assustada. Sumiu. No outro dia, eu falei para meu pai: "Eu vi o meu vô com uma mulher assim, assim, assim no meu quarto". Meu pai falou: "Minha mãe!". Eu devia ter uns dezoito anos. Eu nunca vi uma foto da minha avó. Eu não tinha ideia de como ela era. E eu a vi no meu quarto. Tinha coisa que eu não podia negar que acontecia comigo. Eu sabia que tinha mediunidade, mas eu queria fugir disso por conta das experiências que eu tive na infância.

Quando começou a ter esse problema de alergia, minha máe falou assim: "Minha filha, cê precisa firmar em alguma religiāo". Eu ia de vez em quando na igreja católica. Cheguei a fazer primeira comunhão, mas náo me sentia muito à vontade. Eu sabia que não era ali, mas eu ia. A alergia nas pernas foi ficando muito difícil. Eu fui ficando meio triste, não saía mais de casa. $\mathrm{Eu}$ andava com roupas grandes tentando cobrir o corpo, era aquela coisa. E um dia minha máe veio com meu pai conhecer o Centro, antes de me trazer. À noite, no mesmo dia que veio aqui, ela sonhou com um dos pretos-velhos pedindo a ela que me trouxesse. Como minha mãe é médium desde muito criança, ela falou assim: “Eu tenho que levar ela lá. Pediram, né?”. É um negócio muito engraçado, que eu cheguei passando muito mal porque eu era uma médium em desequilíbrio. Emocionalmente, eu náo estava estável. Energeticamente, eu não estava bem. Eu cheguei aqui sentindo tudo. Tudo. Eu ficava dormente inteira. Mas eu sabia que era aqui, mesmo com todo aquele mal-estar. Eu cheguei e sabia que era aqui. Aquela sensaçáo de "cheguei em casa". Eu me senti à vontade desde a primeira vez que eu botei o pé aqui. Eu sabia que era meu lugar. Eu sentia mal, muito mal e vim na segunda-feira, conversei com preto-velho e ele me passou para sete sextas-feiras seguidas. 
Fiz as sete sextas-feiras. Tinha sexta-feira que meu corpo estava tão dormente que minha mãe tinha que me segurar na cadeira e me trazer para a corrente. Sozinha eu não dava conta. Por isso que eu entendo as pessoas passando mal aqui. Eu vejo mediunidade em desequilíbrio.

Um dia eu estava na corrente. Na época Tia Maria incorporava Pai Joaquim na sexta-feira e ele passava conversando com as pessoas. Ele passou, olhou para mim e falou para o cambono dele: "Essa daí é cavalinho, né?" E eu não entendi o que ele falou: "O quê?". "Você é um cavalo. Cavalo na Umbanda é o médium. Cê é médium, cê sabia?” Eu falei: "Eu desconfiava, mas é a primeira vez que alguém me afirma”. Ele pediu para eu vir conversar com ele na segunda-feira. Uma das poucas vezes que eu falei com Pai Joaquim. Vim conversar com ele na segunda. Eu fui sentando lá e ele falou assim: "Quantas luas a fia tem?”. “Tenho dezenove”. Ele falou assim: “Já tá madura, é dando que se recebe, vamo trabalhá”. Desse jeito. Já me pôs para trabalhar, de cara. Ele pediu para eu conhecer os trabalhos da Casa, para eu ver os trabalhos de estudo, para eu começar. Falou que eu já estava madura, já estava passando da época de realmente trabalhar. Como Pai Joaquim me orientou, fiz o curso de Umbanda, curso de passe, curso de desenvolvimento mediúnico, o 1 e o 2, tudo que aparecia eu ia fazendo. E fui melhorando, melhorando. $\mathrm{O}$ último estágio que eu passei foi na quarta-feira, que estou nessa experiência de sentir ainda. Mas foi desse jeito que eu cheguei aqui. E eu falo que eu cheguei aqui pela dor, mas graças a Deus não foi por ela que eu permaneci. Permaneço aqui por amor. Aqui eu me sinto em casa.

Eu já estou no trabalho de quarta-feira há mais de cinco anos. Eu comecei a sentir mesmo vibração para incorporar com mais segurança - de falar: "Isso não sou eu" - há dois anos. Então, assim, foi um processo. Eu sei que em alguns centros, a gente ouve falar, que tem um período que a pessoa tem que se preparar. A ideia da Casa de Pai Joaquim é que desde o Portal do Céu você já está sendo preparado. Então quando você é encaminhado para um trabalho como um trabalho de terreiro, há orientação da dirigente. Ela chama a gente, tem uma conversa. Nos fala da paciência porque a maioria chega no terreiro achando que o preto-velho já vai chegar dando informação 
e dando consulta. Se a gente chegar lá querendo a coisa para ontem... A comunicação mediúnica são dois lados. Eu estou me preparando daqui, mas o espírito que vai se comunicar comigo, ele também está se adequando à minha vibração. Existem dois lados que precisam ser trabalhados e essa coisa nem sempre é rápida. Então, a dirigente nos pede muita paciência e disciplina porque é um trabalho que exige constância. Não tem como você esperar se afinizar vibratoriamente com um ser vindo um dia, uma vez no mês. Isso náo acontece.

A energia no terreiro é muito diferente de tudo aqui na Casa. Parece um mar de energias. Quando eu entrei no desenvolvimento, eu só suava muito as mãos. Minhas mãos, quando eu estou trabalhando, ficam muito quentes ou ficam muito frias. É uma coisa interessante que eu nunca consegui identificar em que momentos acontece, pois isso varia bastante. Mas elas esquentam muito ou esfriam muito. E era o que eu sentia. Às vezes um arrepio, alguma coisa. De uns dois anos para cá que eu realmente comecei a sentir presenças e aí foi um processo porque eu sou uma pessoa muito... desconfiada, vamos dizer assim. Não que eu náo queria aceitar, mas eu ficava achando que era coisa da minha cabeça. Falava assim: "Isso aqui eu tô inventando, que eu já tô há tempo demais no terreiro e nunca mudou". Eu achava que era coisa da minha cabeça. Até que um dia a Tia Maria e o Valério vieram assistir o trabalho. A Tia Maria, no final do trabalho, falou pra mim: "Por que que cê segura tanto? Eles estão lá girando ao redor". Ela ainda brincou: "Estão te rodeando e você não dá abertura". Eu falei: "Achava que era coisa da minha cabeça". Depois que ela falou assim, eu comecei a ser um pouco mais flexível, mas continuei com as dúvidas. $\mathrm{Na}$ verdade, eu tenho até hoje; dúvida. $\mathrm{E}$ um dia a dirigente do trabalho me deu uma orientaçáo que achei muito fantástica. Ela falou assim: "O preto-velho quer andar, anda. Preto-velho quer sentar, senta". Eu falei assim: "Como é que eu sei se sou eu ou se é ele mesmo?". Ela respondeu: "Cê vai estar sentada lá no toco. Se você achar que é você, levanta". Um dia eu tentei e não consegui levantar. Falei: "Ah, náo sou eu". Nesse início de comunicaçáo a nossa presença é grande demais porque a gente é muito consciente. Entáo, como a minha presença é muito 
grande, eu fico com muita dúvida do que é meu e o que não é. E eu, como eu sou muito desconfiada, eu questiono o tempo inteiro. Isso às vezes até atrapalha a comunicação, porque eu começo a questionar tanto que perco a sintonia. Mas eu já estou aprendendo a permitir mais.

Como eu sou muito cautelosa, eu fico prestando atenção na sensação que me provoca o tempo inteiro. Não sei identificar se é um preto-velho ou uma preta-velha porque é muito novo. Mas eu tenho sentido. Ela costuma ficar pouquíssimo, pouco tempo comigo. Acho que talvez devido à diferença de vibração, não sei. Ela deixa uma energia tão grande que as minhas pernas ficam bambas, as minhas mãos, tudo em mim. Sinto arrepio nas costas. Geralmente, quando é preto-velho você sente uma energia muito forte na altura da cintura ou quando é caboclo, no peito, como se o peito crescesse, varia muito de Linha. É uma emoção que me dá vontade de chorar, mas não de tristeza. Um amor. A gente começa a sentir um pouquinho do que eles sentem. Acho que por isso que essa fase de desenvolvimento mediúnico é táo importante, porque preciso ir, a partir da experiência, pautando o que é meu e o que não é. Mas, fisicamente é isso. Agora, emocionalmente, por exemplo, tem o caboclo. Ele dá uma sensação de força, de coragem. É difícil explicar energia, mas eu sinto isso. Já com preto-velho náo, é uma coisa mais amorosa. E eu aproveito porque a gente não fica, eu não fico tanto tempo incorporada. Incorporação é um termo meio equivocado. Mas é difícil tirar algo que é usado há tantos anos. A ideia é que você sente a energia porque, pelos estudos, a gente sabe que o nosso corpo astral vai se expandindo e, nessa expansão, o espírito consegue se aproximar do nosso corpo astral e é por isso que a gente sente tanto fisicamente. Entáo, os momentos em que eu sinto essas presenças, eu fico conversando mentalmente. Pedindo para eles me ajudarem a compreender o que está acontecendo. Pedindo para eles me intuírem de que forma eu posso melhorar para que essa aproximação aconteça de forma mais equilibrada, mais harmoniosa. Entáo, além de prestar atenção no que eu sinto quando eles chegam, como que chegam, para eu começar a identificá-los, depois que eu sinto que chegou eu começo a travar essa conversa mental, para tentar entender. Você sente essa energia e é como 
se tivesse alguém pensando dentro da sua mente. É uma coisa interessante. Tanto que às vezes eu queria entender como é a mediunidade de audiência, como é ouvir de fora por quê a sensação que eu tenho, a minha, pessoal, é que estão falando dentro da minha cabeça. Eu não ouço uma voz. É como se brotasse um pensamento na minha cabeça. É difícil de explicar: como se estivesse dentro da minha mente. É essa a questáo. Eu sou cautelosa. Dependendo da resposta eu fico: “Será que é minha? Será que não é?" Na quarta-feira, às vezes senta um médium na frente da gente para saudar os pretos-velhos e às vezes dá vontade de falar alguma coisa. E eu seguro muito isso porque eu náo sei se sou eu. Entáo eu fico me policiando mesmo. E às vezes vêm ideias que não tinham passado pela minha cabeça. Falo: "Nunca tinha pensado nisso. Eu acho que esse não é meu, não". E eu fico fazendo esse jogo mental de tentar filtrar. "Eu acho que isso realmente não foi meu". Quando é algo que eu já refleti a respeito, que eu já cheguei a algumas conclusóes, eu fico me questionando: "Não, isso aqui eu acho que é meu". Eu perguntei pra dirigente do trabalho: "Que dia que eu vou ter certeza que sou eu?" Ela falou assim: "Nunca". Nunca. Você sempre vai estar na dúvida. É muito recente essa coisa de manifestar, em mim. Eu comecei a sentir há uns dois anos, mas de um ano para cá é que realmente eu sei que náo sou eu. Eu aceitei. Não sou eu. É pouco tempo para ter certeza das coisas. Então, eu prefiro não ter certeza.

A narrativa de Vitória, além de registrar a dor como motivo de sua chegada ao Centro, traz elementos de uma teoria nativa do desenvolvimento mediúnico, os quais ressalto a seguir. 
Figura 1. Os sete corpos da pessoa

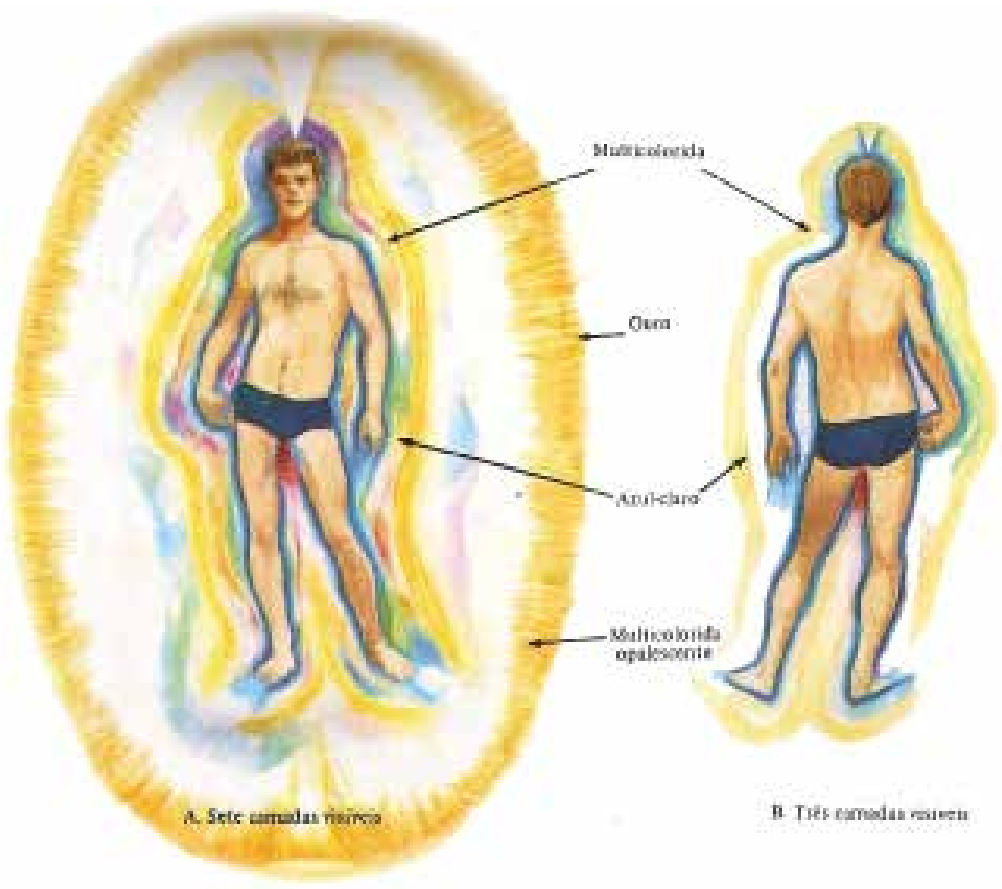

Fonte: Brennan (2006, p. 81). Na umbanda de Pai Joaquim, concebe-se que a pessoa tem sete corpos, os quais são camadas de uma mesma energia que vibra em frequências distintas. Como as moléculas de água apresentam-se no estado sólido, líquido e gasoso, os corpos são constituídos de um substrato único modalizado em estados diferentes. No caso dos “espíritos”, eles náo possuem o corpo físico nem o etérico.

Faz-se necessário reiterar que a/o médium é uma pessoa preparada, antes do início de sua encarnação, para ter sensibilidade mais aguçada e perceber as vibrações espirituais de modo "ostensivo". Isto significa que, se toda pessoa encarnada capta as ondas intangíveis através de suas glândulas pituitária e pineal (a hipófise e a epífise), a médium ou o médium é considerado um ser humano mais suscetível, mais receptivo a tais ondas. E esta suscetibilidade está presente desde a infância, como pontua Vitória. Isto parece acarretar 
sérias implicaçóes para a pessoa. Se a pessoa-médium é sensível às energias de variados matizes, frequências e tonalidades vibratórias e "funciona" como uma "antena", sempre pronta a captar vibraçóes, então ela tem, em seu cotidiano, um cuidado muito sutil em relação a si.

Quando a/o médium chega ao Centro adoentado ou triste - "em desequilíbrio", como diz Vitória - talvez haja, circulando em seus corpos espirituais, energias com as quais ele não consegue lidar. Sua hipersensibilidade faz com que ele passe o tempo todo recebendo essas vibraçóes, ainda sem meios conceituais ou técnicos que possibilitem continuar sereno ao senti-las. Essa hipersensibilidade pode também gerar manifestaçôes descontroladas, como no caso do tio de Vitória.

As vibraçóes que as glândulas pineal ou pituitária captam podem tanto ser elevadas como densas, isto é, tanto vibraçóes agradáveis - aquelas correspondentes a sentimentos de paz, amor, harmonia, respeito, altruísmo - como vibrações desagradáveis - aquelas correspondentes ao ódio, à raiva, ao desequilíbrio, ao egoísmo. A frequência com que essas vibraçóes se movimentam são rápidas ou vagarosas e, assim, caracterizam-se como "positivas" ou "negativas". É daí que decorre a "responsabilidade" mediúnica, pois, uma vez entendida a tarefa escolhida antes de encarnar e iniciado o processo de desenvolvimento mediúnico, dificilmente ele ou ela deixa de perceber as vibraçôes espirituais que antes sentia inadvertidamente.

$\mathrm{Na}$ umbanda de Pai Joaquim, a educação ou desenvolvimento mediúnico é um processo de transmissão de conhecimento e técnicas que tornam a/o médium mais atenta/o e permitem compreender e até mesmo controlar, relativamente, suas inevitáveis percepçôes "sutis". O termo sutil parece mais adequado que "extra-sensorial" pois, embora intangíveis, as vibraçóes causam efeitos tangíveis e concretos no corpo físico dos médiuns. Exemplificam esses efeitos concretos mãos exageradamente quentes ou frias, pernas bambas e arrepios nas costas. Segundo os filhos de Oxalá da Casa de Pai Joaquim, o corpo astral da pessoa "capta" as ondulaçóes vibratórias do pensamento e do movimento do guia espiritual, os quais ressoam no corpo físico. 
A educação da mediunidade começa desde o momento em que a pessoa participa das palestras do Portal do Céu. Após um ciclo de Portal do Céu, de um ano, a pessoa, sentindo a vontade, é encaminhada ao desenvolvimento mediúnico da quinta-feira. Ali, também durante um ano, a cada dia do curso, ela aprende conceitos na parte teórica e, na segunda metade, aprende praticamente. Todos são convidados a sentar-se à mesa e, enquanto se canta os pontos e chamam-se seres das diversas Linhas da Umbanda para manifestarem-se, os médiuns-aprendizes aprendem a identificar as vibraçóes dos guias espirituais que os acompanham. O guia espiritual, por sua vez, também se prepara e busca criar uma sintonia com seu médium; ambos se adequam às vibraçôes dos corpos um do outro. Apenas após dedicar-se a esse curso é que são definidas as pessoas para cada tipo de trabalho, de acordo com as tendências mediúnicas de cada uma.

Como se vê, ao contrário do que poderia parecer, a pessoa-médium não chega na Casa de Pai Joaquim e simplesmente começa a "incorporar", "psicografar", "magnetizar”. É preciso paciência, pois as técnicas para uso das faculdades mediúnicas levam tempo para serem apreendidas. A pessoa traz consigo uma ou várias delas, como uma pedra bruta ainda não desbastada. Não cabe aqui discorrer sobre todas, então enfoco aquela que diz respeito à técnica de "incorporação", citada por Vitória.

Antes de mais nada, o termo "incorporação" é, segundo Vitória, equivocado. O guia espiritual - uma pessoa, um sujeito consciente, com sua vontade, inteligência, movimento individualizados, embora não tenha o corpo físico e o corpo etérico - não entra, e nem poderia entrar, no corpo físico da médium ou do médium. Há, simplesmente, uma transmissão de vibraçôes. Uma médium, por exemplo, sintonizada ao guia, percebe a sua presença e capta, através da pineal e da pituitária, o pensamento do guia. Por outro lado, o corpo astral da médium se dilata e o guia espiritual - preto-velho, criança, caboclo ou qualquer outro ser intangível que estabeleça alguma sintonia com a médium, entrando na mesma faixa de frequência vibratória - aproxima seu corpo astral do corpo astral da médium, possibilitando a comunicação. Influenciando o corpo astral da médium, o 
guia entâo transfere as vibraçóes de seu movimento ao chacra coronário da médium, localizado no corpo etérico. $\mathrm{O}$ chacra coronário está ligado à glândula pineal, que retransmite as informaçóes para o cérebro, o qual, por sua vez, "traduz" o gesto do ser intangível, que ressoa em todo corpo físico da médium. Essa técnica é chamada, no espiritismo, de psicofonia.

Somente após cinco anos de desenvolvimento mediúnico no terreiro, durante as quartas-feiras, é que Vitória se sentiu mais segura em relação às energias que sentia, compreendendo há dois anos que os movimentos, pensamentos e vibraçóes que percebia não eram realmente seus, mas pertenciam a outras pessoas, desencarnadas, as quais são caracterizadas por inúmeros epítetos: espíritos, guias, almas, protetores, mentores, a depender da categoria de ser intangível a que se refere. Vitória ainda não está liberada para realizar atendimentos na Sessão da Caridade junto aos guias que a acompanham.

A faculdade mediúnica de Vitória a permite ouvir mentalmente seus guias espirituais. Ela náo ouve uma voz externa, falando ao seu ouvido, mas sim capta as vibraçóes sutis emitidas pelo pensamento dos mentores e protetores, através da glândula pineal, que traduz essas vibraçóes e retransmite ao seu cérebro a mensagem emitida pelo ser espiritual. Nesse processo, o aparelho fonador de Vitória é impelido a emitir sons, mas Vitória ainda não transmite muito as mensagens orais, pois ela é bastante cautelosa e teme influenciar demais o conteúdo. Isso por quê ela tem embates consigo, questionando a si mesma se o pensamento que se reflete no espelho de sua mente é realmente dela ou não. Ela precisa conscientemente filtrar e diz que, na realidade, nunca terá plena certeza da medida exata em que ela "borra" a mensagem. Vitória ainda "trava" um pouco e obstrui o livre curso da informação através de seu corpo físico, especialmente a sua concretizaçáo na fala. Neste sentido, ela testa a sua própria faculdade mediúnica, quando, sentada no toco no momento da "incorporação", tenta levantar e nấo consegue. Através desta técnica, ela tem entâo a certeza de que está curvada e sentada no toquinho sob a influência da vontade de uma outra pessoa, o guia espiritual.

Nesta espécie de mediunidade, a/o médium tem relativo controle de si e pode influenciar a comunicação. $\mathrm{O}$ peso da personalidade da/o médium 
nessa forma de comunicação "consciente" assemelha-se a uma pessoa que, traduzindo um texto de alta erudição filosófica, não tem palavras para transladar certa frase de uma língua a outra, de um suporte a outro, e acaba por usar vocabulário um pouco menos profundo do que os símbolos metafísicos do filósofo. É apenas com o tempo e através do treino que a/o médium, de fato e de direito, obstrui menos sua tradução da mensagem, permitindo-a ser veiculada através de si com o mínimo de interferências.

\section{CONSIDERAÇÓES FINAIS}

A Erlebnis (experiência vivida) consiste, como vimos, em uma unidade de sentido. Considerei as narrativas como expressão de experiências significativas e como movimento aberto, contextual e interpretativo, que evoca o círculo hermenêutico - compreende-se, explica-se, expressa-se, compreendese, ad infinitum.

Alguém pode, no presente, interpretar sua própria experiência e, olhando para o passado, atribuir significado a ela, tornando-a uma experiência. Expressando-a, consumando-a, a pessoa fecha o círculo, que pode ser novamente aberto quando os outros experienciam essa expressão e a interpretam. Aqui, temos um ouroboros; o símbolo da serpente circular que morde a própria cauda, remetendo a imagens de ciclicidade. Os textos apresentados, autorreflexivos, configuram a exegese das pessoas sobre o que viveram. Eles são a consumação, a expressão e o fechamento de um ciclo de experiência vivida e, em certo sentido, bastam-se a si mesmos. Evitando uma separação rígida entre teoria antropológica e etnografia, busquei respeitar as reflexóes das pessoas sobre sua experiência vivida. Limitei-me, portanto, a ressaltar, entre cada narrativa, o conhecimento vivido.

Como já dito, não estive interessado apenas na experiência vivida enquanto sensaçóes e percepçóes analiticamente consideradas anteriores ou opostas à reflexão e à cognição. Interessou-me mais captar uma experiência - ou, se se quiser, a estrutura de experiência - enquanto processo de 
atribuiçáo de significado ao vivido, como unidade de sentido que envolve percepção, reflexão, ação e expressão. Uma experiência é uma Erlebnis. Como ensina Turner (1985, p. 211, tradução nossa), "uma Erlebnis é distinguível de outra naquilo que tem de específica em relação à vida de um indivíduo ou um grupo como um todo - cada experiência é uma parte de um todo".

Ora, qual é o todo do qual uma experiência (Erlebnis) faz parte? Uma Erlebnis vincula-se a um contexto cultural que provê muito do conteúdo e da forma com a qual a pessoa compreende a si mesma e dá sentido e significado ao que ela vive individualmente. Os termos com os quais a pessoa expressa sua experiência são compartilhados e culturalmente localizados, mas isto não equivale a dizer que o significado está fora da experiência. É através da experiência, entendida como processo, que surge o conhecimento vivido. As narrativas, portanto, demonstram os vínculos existentes entre o conhecimento vivido das pessoas e a epistemologia da umbanda de Pai Joaquim, a qual foi considerada um conjunto de premissas cosmo-ontológicas inter-relacionadas através das quais as pessoas refletem sobre suas próprias concepçôes e técnicas.

Parece-me que o conceito de Umbanda enquanto conhecimento possibilita uma alternativa teórico-metodológica a pesquisas de viés mais sociológico, reiterado em muitos textos sobre o tema. A abordagem da experiência vivida através da qual as pessoas aprendem "um conhecimento que não está nos livros" trazem questóes teóricas e etnográficas para pesquisas subsequentes sobre as múltiplas umbandas, no âmbito dos estudos afro-brasileiros, mas também para estudos que lidem com narrativas, experiência e noção de pessoa em perspectiva antropológica. 


\section{REFERÊNCIAS}

BASTIDE, Roger. As Religióes Africanas no Brasil. 3. ed. São Paulo: Pioneira, 1989.

BELMONT, Rafael Neves Flôres. Opção mágica: conversão de kardecistas à umbanda na cidade de Goiânia. 2007. 128 f. Dissertação (Mestrado em Sociologia) - Faculdade de Ciências Sociais, Universidade Federal de Goiás, Goiânia, 2007.

BERGO, Renata Silva. Quando o santo chama: o terreiro de umbanda como contexto de aprendizagem na prática. 2011. $249 \mathrm{f}$. Tese (Doutorado em Educação) - Faculdade de Educação, Universidade Federal de Minas Gerais, Belo Horizonte, 2011.

BRENNAN, Barbara Ann. Mãos de luz: um guia para a cura através do campo de energia humana. São Paulo: Editora Pensamento, 2006.

BRUNER, Edward. Experience and its expressions. In: TURNER, Victor; BRUNER, Edward. The Anthropology of Experience. Urbana; Chicago: University of Illinois Press, 1986a. p. 3-30.

. Ethnography as narrative. In: TURNER, Victor; BRUNER, Edward. The Anthropology of Experience. Urbana; Chicago: University of Illinois Press, 1986b. p. 139-155.

COSTA, Hulda Silva Cedro da. Umbanda, uma religiäo sincrética e brasileira. 2013. 177 f. Tese (Doutorado em Ciências da Religião) - Departamento de Filosofia e Teologia, Pontifícia Universidade Católica de Goiás, Goiânia, 2013. DESJARLAIS, Robert. Rethinking experience. In: . Shelter blues: sanity and selfhood among the homeless. Philadelphia: University of Pennsylvania Press, 1997. p. 10-17.

FABIAN, Johannes. O tempo e o outro: como a antropologia estabelece seu objeto. Petrópolis: Vozes, 2013. 
GIUMBELLI, Emerson. Presença na recusa: a África dos pioneiros umbandistas. Esboços, Florianópolis, v. 17, n. 23, p. 107-117, 2010.

GUIMARÃES, Maria Beatriz Lisboa. A "lua branca" de Seu Tupinambá e de Mestre Irineu: estudo de caso de um terreiro de umbanda. 1992. $124 \mathrm{f}$. Dissertação (Mestrado em Ciências Sociais) - Instituto de Filosofia e Ciências Humanas, Universidade Federal do Rio de Janeiro, Rio de Janeiro, 1992.

HARTMANN, Luciana. Gesto, palavra e memória: performances narrativas de contadores de causos. Florianópolis: Editora da UFSC, 2011.

INGOLD, Tim. That's enough about ethnography! Hau: Journal of Ethnographic Theory, London, v. 4, n. 1, p. 383-395, 2014.

. O dédalo e o labirinto: caminhar, imaginar e educar a atenção. Horizontes Antropológicos, Porto Alegre, v. 21, n. 44, p. 21-36, 2015.

ISAIA, Artur Cesar. Ordenar progredindo: a obra dos intelectuais de umbanda no Brasil da primeira metade do século XX. Anos 90, Porto Alegre, v. 7, n. 11, p. 97-120, 1999.

LANGDON, Esther Jean. Performance e sua diversidade como paradigma analítico: a contribuição da abordagem de Bauman e Briggs. Antropologia em Primeira Mão, Florianópolis, n. 94, 2007.

. Prefácio. In: HARTMANN, Luciana. Gesto, palavra e memória: performances narrativas de contadores de causos. Florianópolis: Editora da UFSC, 2011. p. 17-21.

LÉVY-BRUHL, Lucien. Introduction. In: . L'expérience mystique et les symboles chez les primitifs. Paris: Dunod, 2014. p. 3-24.

MAGNANI, José Guilherme Cantor. Umbanda. São Paulo: Ática, 1986.

NEGRÃO, Lísias Nogueira. Umbanda: entre a cruz e a encruzilhada. Tempo Social, São Paulo, v. 5, n. 1/2, p. 113-122, 1993. 
NOGUEIRA, Léo Carrer. Umbanda em Goiânia: das origens ao movimento federativo (1948-2003). 2009. 132 f. Dissertação (Mestrado em História) Faculdade de História, Universidade Federal de Goiás, Goiânia, 2009.

ORTIZ, Renato. A morte branca do feiticeiro negro. 2. ed. São Paulo: Brasiliense, 1999.

SÁ JUNIOR, Mario Teixeira. A Invenção do Brasil no Mito Fundador da Umbanda. Revista História em Reflexão, Dourados, v. 6, n. 11, p. 1-14, 2012. SCHECHNER, Richard. What is performance? In: . Performance studies: an introduction. New York; London: Routledge, 2006. p. 28-51. TURNER, Victor. Introduction. In: . From ritual to theatre: the human seriousness of play. New York: PAJ Publications, 1982. p. 7-19. . Experience and Performance: Towards a New Processual Anthropology. In: . On the Edge of the Bush: Anthropology as Experience. Tucson: The University of Arizona Press, 1985. p. 205-226.

. Dewey, Dilthey, and Drama: An Essay in the Anthropology of Experience. In: TURNER, Victor; BRUNER, Edward (Ed.). The Anthropology of Experience. Urbana; Chicago: University of Illinois Press, 1986. p. 33-44.

Recebido em: 17/04/17 Aprovado em: 25/05/17 



\title{
O SIGNIFICADO DO DAIME COMO FONTE DE CONHECIMENTO
}

\author{
Amurabi Oliveiral \\ Felipe Boin ${ }^{2}$
}

Resumo: O presente trabalho busca explorar como o daime é percebido por alguns agentes que fazem uso da ayahuasca em rituais de caráter religioso, mais especificamente, como tais agentes percebem o daime como fonte de conhecimento. Parte-se da crítica pós-colonial à monocultura do saber, reconhecendo a multiplicidade de formas de se produzir conhecimento no mundo. Os dados aqui apresentados são resultantes de entrevistas realizadas com daimistas da cidade de Florianópolis, SC, e buscam explorar a percepçáo destes sobre o daime, contribuindo assim para um debate mais amplo sobre a produção de outros saberes.

Palavras-chave: Santo Daime; Epistemologias do Sul; Saberes Alternativos.

Abstract: The present work seeks to explore how the daime is perceived by some agents that use of ayahuasca in rituals of religious character, more specifically, how such agents perceive the daime as a source of knowledge. It starts from postcolonial criticism to the monoculture of knowledge, recognizing the multiplicity of ways of producing knowledge in the world. The data presented here are the result of interviews conducted with daimists from the city of Florianópolis, SC, and seek to explore their perception of daime, thereby contributing to a wider debate about the production of other knowledge.

Keywords: Santo Daime; Epistemologies of the South; Alternative Knowledge.

1 Doutor em Sociologia pela Universidade Federal de Pernambuco (UFPE), professor da Universidade Federal de Santa Catarina (UFSC). Pesquisador do CNPq. Contato: amurabi_cs@hotmail.com

2 Bacharel em Ciências Sociais e mestrando em Antropologia Social pela Universidade Federal de Santa Catarina (UFSC). Contato: fbboutin@gmail.com 


\section{INTRODUÇÃO}

O campo das Ciências Sociais vem passando por uma forte crítica relacionada à existência de um exclusivismo epistemológico da ciência moderna e diversos autores como, por exemplo, Lander (2005) e Santos (2008) vêm desenvolvendo debates pautados sobre esse paradigma epistemológico que separa absolutamente o conhecimento ${ }^{3}$ científico, marcado por concepções de validade e rigor até então inquestionáveis, e outras formas de conhecimento. Nesse trabalho, pretendemos explorar uma fonte de conhecimento singular, como assim afirmado pelas tradiçóes indígenas e religióes neo-xamânicas: a ayahuasca.

A ayahuasca é uma bebida de origem indígena preparada a partir da infusão do cipó Banisteriopsis caapi e da folha Psychotria viridis ${ }^{4}$. Como aponta Albuquerque (2014), ela é conhecida por uma diversidade de nomes, dentre os quais: natema, yagé, nepe, kahi, caapi, nixi pae, shori, kamarampi, cipó, além de daime, vegetal, entre outros. Ela é utilizada tanto por grupos indígenas quanto pela população mestiça ou cabocla da Amazônia, bem como por diversos sujeitos dos centros urbanos, com diferentes finalidades: medicinais, religiosas, divinatórias, pedagógicas, dentre outras (Labate, 2002).

De acordo com Cemin (2002) tanto o Santo Daime quanto a Uniấo do Vegetal são oriundas do chamado "xamanismo ayahuasqueiro", ou seja, "são parte da grande tradição de muitos índios da Amazônia de entrar em contato com o sagrado através da ayahuasca” (Cemin, 2002, p. 347). Este artigo volta-se para a religiấo do Santo Daime, tendo como base os estudos anteriormente desenvolvidos sobre essa religião bem como a minha inserçáo pessoal em seus rituais.

3 Apesar das diferenças linguísticas, faremos o uso das palavras "conhecimento" e "saber" como sinônimos durante o desenvolvimento do trabalho.

4 Este é o modo "clássico" de se preparar ayahuasca. Existem, contudo, outras espécies que podem ser acrescentadas, além de outra forma de preparo que náo prevê o cozimento das plantas. Para maiores informaçôes ver Sáez (2014) e Luna (2005). 
O Santo Daime foi fundado em 1930 pelo maranhense Raimundo Irineu Serra, o Mestre Irineu, em Rio Branco, no estado do Acre. Na década de 70, após a morte do Mestre Irineu, Sebastião Mota Melo, também conhecido como Padrinho Sebastião, funda o Centro Eclético da Fluente Luz Universal Raimundo Irineu Serra (CEFLURIS), dando início assim à expansão do Santo Daime.

O Santo Daime é considerado como um movimento religioso possuidor de um caráter híbrido já que, ao mesmo tempo, articula características de religiôes cristâs, de matrizes africanas, de correntes espíritas, como também utiliza a ayahuasca dentro da sua própria cosmologia. Nesse contexto religioso, ocorre uma ressignificação da milenar bebida indígena de nome ayahuasca e seus adeptos costumam chamar a própria bebida de "Santo Daime" ou apenas daime $e^{5}$ Esse novo nome indica também uma invocação do espírito da bebida (dai-me), a quem seus adeptos pedem para "dar" iluminação, luz, saúde (Albuquerque, 2011).

Como aponta Groisman (1999), por ser uma substância psicoativa, a utilização do daime foi investigada pelo Conselho Federal de Entorpecentes (COFEN). As investigaçóes confirmaram e permitiram o uso religioso do daime e não apontaram fatores prejudiciais à saúde física ou psíquica daqueles que tomam essa bebida.

Por ser uma substância psicoativa, muitas vezes ela é classificada como "alucinógena", deturpando seus efeitos e distorcendo a complexidade que envolve a sua utilização. Como aponta Groisman (1999), ser "alucinógeno" é ser veículo de um estado "alucinatório", onde experienciam-se fantasias e ilusôes. Dentro dessa visão, a experiência seria apenas uma fuga da realidade. Portanto, definir o daime como alucinógeno ou tóxico não nos ajuda a compreender a sua utilização, que envolve diversos componentes sóciosimbólicos corroborados pela aprovação coletiva.

5 Durante todo o trabalho, iremos nos referir à religião como Santo Daime ou Daime. Se tratando da bebida, nos referiremos à mesma como daime, em itálico. 
Neste movimento religioso é através da experiência proporcionada pela ingestão da bebida, da relação da bebida com aqueles que a ingerem, que esse conhecimento é desenvolvido. Esse aspecto pedagógico atribuído à ayahuasca está relacionado à ideia de que uma "planta professora" é portadora de uma inteligência com a qual é possível obter conhecimentos. Para Luna (2002, p. 183) 'algumas plantas teriam a faculdade de 'ensinar' às pessoas que os procuram. A ayahuasca seria uma dessas plantas mestras, porta de entrada que permitiria um conhecimento cada vez maior do mundo natural e que por sua vez indicaria a presença e uso de outras plantas de poder".

Metzner (2002) também aponta que a "educação pelas plantas", como modalidade de prática educativa, difere dos processos de aprendizagem formais da modernidade. Sob um estado de expansão da consciência que resulta da ingestáo da ayahuasca, o indivíduo que a utiliza entra em um estado de êxtase cuja sabedoria remete às lógicas da tradição xamânica. Groisman aponta o xamanismo como "um sistema complexo de conhecimento do mundo, cuja definição está submetida às diferentes manifestaçôes que assume nos grupos em que aparece como sistema simbólico central" (Groisman, 1999, p. 40).

Dentre os vários artigos, teses e dissertaçóes que compōem o balanço bibliográfico referente ao uso da ayahuasca, diversos autores apontam que para os indígenas a ayahuasca "[...] é a planta que dá o conhecimento, ela é a fonte do conhecimento necessário para se viver corretamente" (Luz, 2009, p. 62). Labate e Araújo, no agradecimento de $O$ uso ritual da ayahuasca $(2009)^{6}$, agradecem à ayahuasca e a exibem como uma fonte de conhecimento. Mas que conhecimento seria esse? $\mathrm{O}$ que querem dizer com conhecimento e, ainda, como esse conhecimento é transmitido?

Interessa-nos neste trabalho explorar o daime como uma fonte de conhecimento. Desse modo, objetivamos compreender, a partir de categorias

6 Como apontam Labate e Araújo (2009) a organização desse livro surgiu a partir do Primeiro Congresso sobre o Uso Ritual da Ayahuasca, cujo objetivo era estudar os usos rituais da ayahuasca em diferentes contextos que vão das cerimônias indígenas aos cultos urbanos.

Debates do NER, Porto Alegre, ANo i 8, N. 32, P. 203-23 I, JUl./Dez. 2017 
nativas dos daimistas, como ocorrem os processos de produção e transmissão dos conhecimentos do daime dentro das cerimônias do Santo Daime.

Portanto, o que pretendemos realizar nesse trabalho é um diálogo epistemológico, uma vez que estamos estudando uma bebida que é considerada pelos daimistas como uma planta professora, portadora de inteligência, através da qual é possível obter conhecimentos. Como apontam Santos, Nunes e Meneses (2004) não é possível conceber a possibilidade de uma epistemologia descolada de uma ontologia, portanto, de forma a compreendermos no que se funda a concepção do daime ser uma fonte de conhecimento e explorarmos como ele é produzido e transmitido, devemos considerar em primeiro lugar a ontologia, a cosmologia daimista.

\section{BREVE HISTÓRICO DO SANTO DAIME}

Para uma melhor compreensão por parte do leitor do contexto no qual estamos situados realizaremos aqui uma breve contextualização histórica acerca do Santo Daime, que constitui uma religião brasileira de caráter híbrido, formada a partir de um conjunto muito diverso de elementos culturais. A cosmologia e as formas rituais daimistas correspondem a um conjunto de mudanças que aconteciam quando emergia a religião, que surgiu no interior da floresta amazônica no início do século XX e cuja principal característica é a ingestão da bebida psicoativa chamada daime. Sua fundação remonta aos anos de 1920 e 1930 no interior do estado do Acre, no Brasil e sua organização, bem como sua cosmologia e suas características rituais, remontam aos processos de urbanização que ocorriam no país na época.

Essa religiáo pode ser definida como um movimento eclético de caráter espiritualista, pensando esse ecletismo mais como um conjunto de valores do que uma escola de pensamento. Essa denominação é adequada, pois representa a existência de diversos sistemas religiosos e cosmológicos dentro da doutrina do Daime: umbanda, esoterismo, espiritismo kardecista, catolicismo, entre outros. A palavra doutrina, aqui, serve tanto para delimitar 
a identidade social e grupal daqueles que estáo ligados ao grupo como representa também o conjunto de significados que define as motivaçóes grupais (Groisman, 1999). Originalmente, o grupo que formou o Santo Daime era composto, praticamente, de ex-seringueiros que, com o declínio da exploração da borracha, passaram a viver na cidade de Rio Branco, Acre (Goulart, 2009).

Um desses seringueiros foi Raimundo Irineu Serra (1892-1971), o Mestre Irineu $^{7}$, maranhense e fundador do primeiro núcleo do Santo Daime no Brasil. Enquanto exercia o seu ofício de seringueiro, entrou em contato com os nativos da Amazônia, perto da fronteira acreana com a Bolívia e, a partir daí, iniciou-se no uso ritual da ayahuasca. Mestre Irineu foi um dos líderes espirituais mais importantes da doutrina, em conjunto com Sebastiáo Mota de Melo (1920-1990), ou Padrinho Sebastião.

Como aponta Albuquerque (2011), na década de 30 do século XX, na periferia da cidade de Rio Branco, estado do Acre, Brasil, Raimundo Irineu reuniu um pequeno grupo de pessoas que eram negras em sua maioria e

[...] começou o trabalho com a ayahuasca operando, nesse processo, uma cristianização do uso da bebida que passou a obter o status de sacramento religioso, além de outra denominação: daime. A expressão daime, além de mais fácil de ser pronunciada (do que ayahuasca) remete ao verbo dar, indicando a invocação que deve ser feita ao espírito da bebida no momento de sua ingestão (ALBUQUERQUE, 2011, p. 153).

No que tange à transformação simbólica da ayahuasca em daime, sacralizando a bebida, é exatamente o "resgate crístico pela via enteógena" (Alverga, 1998, p. 20), um dos fundamentos essenciais do Santo Daime. Diferentemente de outras religióes e caminhos espirituais, o contato com o sagrado nessa religião se dá por meio da utilização das plantas sagradas, neste caso, pela ingestão do daime. Uma evidência imediata disto é a centralidade da

7 La Rocque Couto (1989) fornece uma biografia de Raimundo Irineu Serra, apresentando a trajetória pessoal do mesmo até se tornar Mestre Irineu. 
bebida para a sobrevivência da religião e, portanto, a consequente necessidade da matéria prima (a folha e o cipó) para o seu preparo. Isto implica em uma preocupação com o plantio das espécies e o cuidado com a floresta amazônica, seu habitat natural (Albuquerque, 2011).

Como aponta Metzner (2002), o uso de enteógenos aparece como uma possibilidade de o sujeito reencontrar a divindade que habita dentro de si, fazendo com que esse sujeito possa "voltar a ser ele novamente" (Metzner, 2002 , p. 20). O processo de expansão de consciência, aqui, se aproxima do sentido socrático do autoconhecimento ${ }^{8}$, integrando-se à visão dos xamãs que utilizam a ayahuasca, "pois eles afirmam que a beberagem não só lhes dá uma ideia mais profunda de si mesmos como também uma nova e melhor maneira de viver" (Metzner, 2002, p. 23).

A religião do Santo Daime engloba duas vertentes principais: A "linha do Alto Santo" e a "linha do Padrinho Sebastião". O levantamento feito por Labate, Rose e Santos (2008) aponta que "a linha do Alto Santo" permaneceu praticamente restrita ao estado do Acre e que seus centros funcionam de maneira autônoma, apesar de reivindicarem uma origem comum e manterem relaçóes de proximidade. Em 2008, de acordo com o levantamento realizado, essa vertente do Santo Daime contava com oitocentos adeptos.

Já a "linha do Padrinho Sebastiāo" se expandiu nacional e internacionalmente a partir do final da década de 70 e o principal grupo dessa linha é a Igreja do Culto Eclético de Fluente Luz Universal (ICEFLU), originalmente conhecida como Centro Eclético da Fluente Luz Universal Raimundo Irineu Serra (CEFLURIS), entidade civil e instituição religiosa que articula e coordena o funcionamento de núcleos daimistas ligados ao ramo do Padrinho Sebastião, como é o caso do Céu do Patriarca São José, localizado em Florianópolis, no estado de Santa Catarina, Brasil. Atualmente, o líder do ICEFLU é o Padrinho Alfredo Gregório (1950-), filho de Sebastião de Mota Melo e de Rita Gregório de Melo (1925-), também conhecida como Madrinha Rita.

8 Para Sócrates, o autoconhecimento seria a auto-observação, o conhecer-te a ti mesmo. 
Quando Raimundo Irineu Serra morreu, o Padrinho Sebastiāo introduziu mudanças organizacionais no Santo Daime como, por exemplo, a inclusão de práticas de incorporação em suas cerimônias, aproximando-se assim tanto da umbanda como do kardecismo espírita (Labate, 2002). Essas diferentes práticas ainda estão em fase de consolidação dentro do corpo doutrinário do Santo Daime e são características da "Linha do Padrinho Sebastiáo", fator que distancia o grupo da sua matriz original, o Alto Santo?.

Além disso, Padrinho Sebastião adicionou uma nova missão à doutrina do Santo Daime, que consistia em realizar um êxodo da religiâo. O CEFLURIS começou a se espalhar pelos principais centros urbanos no Brasil, em cidades como Sáo Paulo e Rio de Janeiro e, atualmente, como aponta o sítio eletrônico do Santo Daime ${ }^{10}$ existem aproximadamente cinquenta igrejas do Santo Daime no Brasil. Assis e Labate (2014) ${ }^{11}$ apontam que o processo de diáspora do Santo Daime alcançou ao menos 43 países, entre eles Estados Unidos, Canadá, México, Espanha, Holanda, Japão entre outros, totalizando cerca de 60 centros. O ICEFLU conta atualmente com cerca de seis mil participantes filiados no Brasil e no exterior.

\section{O DAIME COMO SUJEITO DE CONHECIMENTO}

Como já indicamos, nosso trabalho insere-se no lastro de uma série de reflexôes que vêm sendo realizadas no campo das Ciências Sociais e que visam, justamente, a criticar o que Santos (2008) define como uma monocultura do saber, que segundo o autor "consiste na transformaçáo da ciência moderna e da alta cultura em critérios únicos de verdade e de qualidade

9 Labate (2002) também aponta que até momento não havia sido realizada nenhuma pesquisa sobre o processo de modulação dessas diferentes práticas dentro do conjunto simbólico daimista.

${ }^{10} \mathrm{O}$ sítio eletrônico do Santo Daime está disponível em: <www.santodaime.org>.

${ }^{11}$ A obra apresenta um panorama sobre a internacionalização das religiōes ayahuasqueiras brasileiras. 
estética, respectivamente" (Santos, 2008, p. 102). De forma a substituir esse posicionamento, o autor propóe uma ecologia do saber, na medida em que reconhece que não existe nem ignorância em geral, nem saber em geral. Mais que isso, o autor afirma que "a aprendizagem de determinados saberes pode implicar o esquecimento de outros e, em última instância, a ignorância destes" (Santos, 2008, p. 106).

Compreendemos assim, que explorar as possibilidades de pensarmos o daime enquanto sujeito de conhecimento nos possibilita ampliar a compreensão acerca das formas de aprender e dos saberes aí implicados. Trata-se, portanto, de partir da realidade empírica para a realização de uma crítica epistêmica, o que será articulado a partir do entendimento dos próprios nativos - que experienciam a ingestão do daime - acerca dos processos de aprendizagem vivenciados nos processos ritualísticos.

Reafirmamos aqui a compreensão do daime enquanto uma planta professora (Luna, 2002) ou, como aponta Goulart (2009), uma planta espírito, em conjunto com a necessidade de explorarmos diferentes concepçôes de conhecimento (Santos, 2008), buscamos entender a partir dos próprios daimistas e de suas categorias como o conhecimento do daime é produzido e transmitido.

Para isso, entrevistamos cinco pessoas de perfis sociais diferentes e realizamos perguntas que abordavam aspectos relacionados às trajetórias dos entrevistados, à inserção dos deles no Santo Daime, como também perguntas que tratavam das compreensóes dos mesmos sobre o daime.

No que tange aos perfis sociais e às trajetórias dos mesmos, essas possuem aproximaçóes e distanciamentos. Foram entrevistadas duas mulheres e três homens, cujas idades variam dos 25 aos 55 anos. Nenhum dos entrevistados apresenta uma formação semelhante ou sequer em áreas semelhantes, sendo elas: naturologia, educação física, história, administração e um dos entrevistados não possui formação em nível superior, apesar de exercer a atividade de designer gráfico. Ainda que não seja significativa estatisticamente a amostra aqui utilizada, ela conflui com uma tendência mais geral que observamos 
no campo das "terapias alternativas", que é uma forte presença de classes médias escolarizadas (Martins, 1999).

Quando questionados sobre possuírem alguma religiáo, as respostas foram distintas. Todos os entrevistados são fardados no Santo Daime e a compreensão dessas pessoas no que diz respeito à religião nos ajudará a compreender o entendimento dos mesmos em relação ao daime, nos aproximando assim do objetivo de nossa pesquisa. Os que consideram o Santo Daime como uma religião relatam:

Considero o Santo Daime a minha religião. Assim, é um caminho né, que eu baseio a minha evolução nesse caminho aí. Sigo nesse caminho para poder ir compreendendo melhor essa questão da vida, da espiritualidade. Acredito que esse é um caminho seguro de seguir na vida, tenho o daime como mestre.

Considero o Santo Daime uma religião, uma filosofia, o Santo Daime é meu terapeuta, me induz ao autoconhecimento. Eu era da igreja católica e fiquei muito tempo sem frequentar religião nenhuma... Antes de ir no Daime eu estava frequentando Allan Kardec, hoje sou daimista, sou fardada.

Por sua vez, os outros entrevistados declararam que mesmos sendo daimistas não consideram o Santo Daime uma religião, mas uma filosofia de vida ou um segmento espiritual de conexão com o divino. Esses demonstraram interesse também em outras religióes, declarando-se cristãos, daimistas, umbandistas, budistas, espíritas. Um desses relatos merece destaque por destoar dos outros:

Eu nasci dentro de uma família umbandista, mas não me considerava uma pessoa religiosa com relação à umbanda. Eu frequentava umbanda, quimbanda, qualquer lugar que me chamasse eu ia. Aí eu comecei a ir no centro espírita, gostava muito, tomar passe, mas não tinha assim como religião. Aí eu conheci o Santo Daime e consegui compreender melhor esse aspecto religioso. Conheci a doutrina e por um tempo fiquei assim com esse conceito de religião. Hoje vejo diferente, não me considero religioso, mas um homem de fé, um livre pensador que conhece umbanda, Santo Daime, kardec, budismo. 
Eu me considero uma pessoa que faz essa doutrina do Santo Daime, esses trabalhos, mas não estou preso a esse padrão religioso. Acho importante religião, todas essas ferramentas são importantes na vida da pessoa. Estou inserido nesse contexto do Santo Daime, mas não me considero daimista, assim... Estamos em um processo de evolução dentro do planeta, entâo não podemos estar presos numa religiáo ou sistema religioso. Se eu disser que o daime é a melhor coisa do mundo estou sendo fanático. Devemos questionar tudo, inclusive Deus.

Esse entrevistado, em particular, comentou que "a religião, todo caminho espiritual, é como uma bicicleta com rodinhas, para ajudar a gente na nossa evolução". E que "não existe espiritualidade sem estudo, se não estudar é uma ferramenta enferrujada, pode tomar daime 300 anos que não aprende nada, porque você está ignorante em relação às coisas que estão à sua volta”. Apesar da curiosa e questionadora posição desse entrevistado em relação às religióes, notamos que, como os outros entrevistados, ele possui um conjunto de valores e concepçôes que podem ser definidos por possuírem um caráter espiritualista.

Como vimos, o próprio Santo Daime apresenta em sua constituição um caráter híbrido que articula diversos sistemas religiosos, entretanto, os entrevistados apontam uma ligação externa com esses sistemas, seja visitando centros espíritas, centros de umbanda, templos budistas, entre outros. $\mathrm{O}$ interessante aqui é a maneira com que esses diversos sistemas se integram no que os entrevistados chamam de "caminho espiritual".

No que tange à relação desses sujeitos com o Santo Daime um dos entrevistados toma o daime há 22 anos, dois deles tomam há 9 anos, um há 7 e ainda, uma outra pessoa toma há 2 anos. Todos conheceram o Santo Daime através de amigos ou familiares. O entrevistado que toma o daime há 22 anos conheceu o Santo Daime em Porto Alegre e a que toma há 2 anos conheceu a ayahuasca em uma cerimônia indígena, mas em seguida começou a participar somente dos trabalhos do Santo Daime. Os outros tomaram a primeira vez no Céu do Patriarca São José, em Florianópolis. 
Todos relataram a intensidade e a importância que deram à primeira vez que tiveram uma experiência com o daime. Um dos aspectos interessantes apontados pelas pessoas entrevistadas e que as levou a continuar tomando o daime é que ele as fez mudar de vida.

Foi importante pra mim na época. Eu era católico, tinha dezoito anos, saí de casa e estava tentando buscar coisas diferentes. Foi bem intenso, uma porta de entrada para um outro mundo, transformou a minha vida de várias formas. Eu andava em um caminho e o daime abriu um novo portal que me fez mudar totalmente de vida. Tudo o que me aconteceu depois que eu tomei o daime até hoje foi o daime que me trouxe, ele me fez trilhar todo esse caminho até aqui.

Foi muito forte, muito forte. Foi um inferno. Eu trabalhava num meio que era uma coisa maluca, achava que estava no céu e estava no inferno, tirou um peso das minhas costas... Mas foi um renascimento que me abriu uma cortina, a medicina abriu uma cortina e me mostrou coisas que eu náo estava conseguindo ver, sentir, isso me tocou profundamente e mudou minha vida profundamente.

Pra mim foi uma surpresa e uma descoberta, porque eu sabia que tinha que mudar de vida. Eu estava como todo mundo vive, não tinha muita fé. Aí quando fui no Daime foi assim, uma revelaçâo. Eu tive uma revelação assim que eu senti a força da Virgem Maria, de Jesus e de José. Quando veio aquela força apagou tudo, as memórias, a mente vai pro espaço, o ego, vai tudo. E o que me segurou foi isso, Jesus, Maria e José, porque era muito forte, assim, muito forte. A partir dali eu nunca mais parei, nunca mais.

Chama a atenção o fato de todos os participantes relatarem que todas as vezes que eles tomam o daime a experiência é diferente e que não existiu, desde que começaram a tomar, nenhum trabalho semelhante. Repete-se ainda a ideia de uma ruptura em termos de biografia após a ingestão do daime. Notadamente esse aspecto é possibilitado - mas não limitado - pelas próprias mudanças que ocorrem no campo religioso na modernidade, que 
implica no fim das identidades religiosas herdadas e na ampliação do leque de escolhas para se vivenciar o sagrado (Hervieu-Léger, 2008).

Ainda que fuja ao escopo deste artigo, é importante compreender que as mudanças vivenciadas no campo religioso com a modernidade têm ampliado a possibilidades postas para os sujeitos no nível das experiências, isso fica ainda mais evidente no movimento Nova Era (Amaral, 2000; Oliveira, 2014). Retomando as ideias desenvolvidas por Hervieu-Léger (2008), na modernidade religiosa torna-se possível inclusive "acreditar sem pertencer" e "pertencer sem acreditar". O que observamos no Daime é um fenômeno que só poderia ser vivenciado, ao menos nestes moldes e para estes sujeitos, na modernidade religiosa, quando as experiências e as possibilidades são ampliadas.

As diferenças relatadas em comparação às primeiras vezes que tomaram o daime vão desde enjoos e desconfortos que tendem a diminuir, como também ter um emocional, uma mente mais limpa, trabalhar de maneira integrada com o daime, de uma maneira mais leve. Relatam também diferenças que dizem respeito ao antes e ao depois do fardamento, onde contam que esse corresponde a uma responsabilidade que eles assumiram com eles mesmos e com o Santo Daime, dando um voto de confiança ao mesmo.

Ser fardado é uma responsabilidade com a egrégora que tu se encontra, é como se fosse uma graduação. É assumir uma responsabilidade espiritual.

Pra mim ser fardado é totalmente diferente, mas nada místico ou religioso, porque minha forma de lidar com o daime é bem mental, bem espiritual. Quando você se farda você dá um voto de confiança total no Mestre Irineu ali, pra o que ele fez. É um voto de confiança que te faz estar mais ali dentro do daime.

Meu processo de fardamento foi um processo de comprometimento maior comigo mesma, com o autoconhecimento. Eu vejo o daime sempre como ferramenta para o autoconhecimento. Entra no meu organismo pra me levar a ver coisas, facilitar a minha visáo de mim mesma, é uma ajuda para que eu enxergue coisas que não consigo enxergar na densidade da matéria. Eu tenho 
uma visão mais ampla sobre meu ser. Me ajuda a identificar algumas coisas que eu preciso melhorar, as partes inferiores que eu preciso trabalhar. Então foi uma questão de mergulhar mais fundo nesse processo.

Alguns dos entrevistados possuem também um comprometimento maior com o Santo Daime. Como supracitado, todos eles são fardados, mas, além disso, ao menos três deles exercem o trabalho de fiscal durante os trabalhos. Quando questionados sobre a relação dos ensinamentos do daime com os hinos, relataram que o daime pode ensinar sem os hinos, mas que esse seria um outro tipo de trabalho espiritual. Para eles, os hinos vêm do astral, do mundo espiritual, e dentro do Santo Daime servem como guias, coordenadas para a experiência das pessoas, para que essas tenham algum direcionamento dentro das cerimônias.

Um outro aspecto abordado na entrevista trata do que os entrevistados consideram que o daime como bebida é, sem levar em conta os aspectos religiosos do Santo Daime. Foram questionados sobre o que eles acham que o daime ensina, as mudanças percebidas após a utilizaçáo da bebida, de onde vem esse conhecimento do daime e se os diferentes tipos de daime (com graduaçóes diferentes) ensinam coisas diferentes. As respostas para essas perguntas foram diversas.

Como vimos em relatos acima, alguns dos entrevistados tratam o daime também como uma ferramenta, um atalho que leva ao chamado autoconhecimento. Essa ideia de autoconhecimento é possivelmente uma das mais difusas em meio às novas espiritualidades que se difundem a partir da segunda metade do século XX (Amaral, 2000; D’Andrea, 2000; Siqueira, 2003; Tavares, 2012; Oliveira, 2015), e encontra espaço também no Santo Daime. Sem embargo, chamamos a atenção que neste contexto esse processo origina-se a partir de um processo de inteligibilidade mútua entre dois diferentes sujeitos, o daime e aquele que o ingere.

De acordo com uma das entrevistadas: "É como se fosse ver a minha vida de um ângulo de fora da minha perspectiva, abre uma cortina pra olhar para o inconsciente com mais facilidade”. Dois entrevistados ainda disseram que o daime é como se fosse um terapeuta particular. 
É uma bebida divina, uma bebida de cura, simplesmente isso pra mim. Cura interior, cura física, emocional, mental e cura do planeta, que eu considero. $\mathrm{O}$ daime é dai-me, né? É pedir mesmo, é pedir e agradecer. Pede ao daime que sempre funciona.

A bebida é um sacramento. Eu até acho assim, Santo daime acho exagero, prefiro o nome ayahuasca... Santo? Uma coisa santa, não sou a favor desse nome. Acho muito preso a uma religião. É uma bebida que expande a consciência e que serve para ajudar muitas pessoas, tira as pessoas do adormecimento que a pessoa tem no cérebro dela.

Especificamente o que a ayahuasca faz, não o daime, não a religião, tudo junto, mas a função da ayahuasca é assim, te mostrar uma função diferente, uma lógica diferente, um mundo diferente. É uma bebida que faz com que tu mude teu estado de consciência... Traz vários sentimentos juntos, de felicidade, realização, medo. Eu super parto do princípio que o daime é uma entidade senciente, um ser senciente.

Observamos novamente o caráter terapêutico dado ao daime como algo que realiza curas sejam elas físicas, mentais ou espirituais. Um dos entrevistados, inclusive, o chama de "medicina da floresta". Essas curas podem se manifestar na forma de vômitos ou diarreias, porém é relevante destacar que esse processo de cura o leva a um estado novo, diferente daquele que anteriormente ele acessou. Não se trata, portanto, de simplesmente voltar a um estado anterior de "saúde", mas sim, de acessar outro nível de experiência (Csordas, 2008).

O nome daime ou ayahuasca parece ser indiferente para dois dos entrevistados, que inclusive questionam o nome "Santo" dado a bebida e apontam que a importância está no aspecto da alteração de consciência e abertura para uma lógica diferente, uma compreensão de mundo diferente. Ainda, esse caráter de entidade dado ao daime por um dos entrevistados também está presente na fala de outras pessoas. 
O daime ensina porque ele é um ser de cura, um ser espiritual. Assim como a gente tem em todas as plantas, todos os pássaros, todas as árvores, toda terra, a gente tem um espírito ali. $\mathrm{E}$ a gente, a gente tem um espírito dentro da gente também.

A bebida é um remédio pra mim, pro corpo, pro espírito, pra alma. Um ser divino. É uma medicina da floresta. $\mathrm{O}$ daime é aquela consciência superior que você tem, ele vai e te conecta com ela, com teu eu superior, e a partir daí que vem o conhecimento. Acredito que seja por aí.

Essa concepção dos entrevistados sobre o daime ser um ser, uma entidade com espírito, pode ser compreendida a partir do perspectivismo ameríndio de Viveiros de Castro (2015). Como vimos, nessa concepção o mundo é habitado por diferentes espécies de sujeitos ou pessoas, humanas e náo humanas, que o apreendem segundo pontos de vista distintos. Todas essas espécies de sujeitos são centros de intencionalidade e considerar o daime como um ser implica, ainda de acordo com o perspectivismo ameríndio, em trabalhar com a dissolução entre humanos e não humanos, compreendendo-os a partir de um mesmo campo sociocósmico.

As mudanças causadas pelo daime na vida das pessoas estão relacionadas ao que elas dizem aprender com a bebida, aos ensinamentos que ela passa. Um aspecto interessante comentado por ao menos três entrevistados é que para aprender algo com o daime é necessário que se esteja disposto a aprender. Caso não haja essa disposição, relatam que é possível passar a vida inteira tomando o daime e não aprender nada. Observamos aqui uma concepção de que não adianta apenas tomar o daime para aprender algo com o mesmo, é necessário pedir o ensinamento. Como relata um dos entrevistados acima, "o daime é dai-me, é pedir".

Ele ensina a gente a se curar, ensina a ter amor, compaixáo pelas pessoas, pela sociedade, pelo mundo. Me trouxe o entendimento da natureza, das plantas, do que as energias trazem pra ti. Mudou completamente tudo na minha vida, minha relação com a minha família, eu aprendi a compreender, 
aceitar, respeitar. Mudou minha relação perante a sociedade. Tudo mudou pra melhor, entendimento da vida, do próprio coração. Eu sinto vigor, às vezes fico mais sensível, é raro, mas sempre me revigora e traz disposição. Mas é muito complexo, é o entendimento às vezes interior de cada um. Pra mim conhecimento é o que a gente guarda no nosso coração.

O daime traz essa relaçáo de coisas que consegui aprender e vivenciar, as informaçôes que eu consigo aproveitar pra minha vida. Ser eu mesmo, sem máscaras, sabe? Porque a gente carrega muita máscara, de querer agradar os outros ou querer atençáo também.

O que você precisa aprender ele ensina, o que você achar importante, o que você quer aprender. $\mathrm{O}$ que você estiver precisando aprender ele vai facilitar, seja música, seja processo de raciocínio, de criatividade. Facilita todo o aprendizado que você queira aprender, o propósito que você tenha, você potencializa ele com o daime. A mudança fundamental é de consciência, mas também favorece tua saúde, tu sente o vigor que ela dá.

Albuquerque (2012) aponta, a partir de uma análise das etnografias sobre o uso da ayahuasca entre indígenas e seringueiros da Amazônia, os saberes da ayahuasca - não especificamente do daime - em saberes "de natureza ecológico-ambiental, saberes cognitivos, estéticos, medicinais, e para a paz" (Albuquerque, 2012, p. 355). Podemos observar em todos os relatos expostos até agora a existência de diversas aproximaçóes com esses saberes relatados por Albuquerque (2012).

Os entrevistados comentaram sobre uma mudança clara em relação à ética, na importância de se ter mais educação e respeito ao próximo. Relataram a importância do daime para uma mudança de consciência, no aprendizado de se relacionar melhor com as pessoas, no processo de conscientização de seus relacionamentos. Ainda, relataram saberes relacionados a curas físicas, mentais, espirituais, processos criativos, entre outros.

No que diz respeito aos diferentes tipos de daime ensinarem coisas diferentes, os entrevistados relataram que em um sentido mais amplo poderia se 
dizer que sim, há uma diferença entre os tipos de daime, mas que se tratando das experiências que esses proporcionam a concepção geral é que os efeitos sempre variam de pessoa para pessoa e, certas vezes, um daime mais forte, mais concentrado, pode náo surtir efeito e, em seguida, ao tomar um daime considerado menos apurado, a experiência pode ser intensa.

Já se tratando de onde vem os conhecimentos transmitidos pelo daime, alguns entrevistados sustentaram a posiçấo do daime ser um ser divino, como aponta o próprio hino Ser Divino: "esse ser divino, transformado em líquido [...]". Por outro lado, um dos entrevistados comentou: "Não é que ele ensina, ele me estimula a enxergar os meus valores". Destacamos dois comentários de pessoas que buscaram especificar de onde vem o conhecimento transmitido pelo daime.

Ele traz conhecimento porque traz uma transformação pessoal, mas acho que pra entender que isso é um tipo de conhecimento a gente tem que ampliar o que a gente entende enquanto conhecimento. Para mim a gente adquire conhecimento através de experiências, não só a partir do conhecimento formal. E o daime é uma experiência que não é simples como ler um livro ou ter uma conversa, porque tu ingere uma bebida que faz com que tu mude teu estado de consciência e é a partir dessas experiências conseguimos adquirir conhecimento. $\mathrm{O}$ daime causa uma indução meditativa, ele trabalha com outras dimensões, dissociação do espaço e tempo, para entrar em contato com o mundo espiritual. É de lá que vem esses ensinamentos. Uma coisa muito básica quando você faz um trabalho de daime é que parece que passou um milênio e passou uma hora. Eu acho que o daime consegue criar uma lógica social diferente da racionalista urbanizada europeia, né? As pessoas se organizam em comunidade, por exemplo. A coisa ligada ao bem estar de vida... E acho que isso está ligado a uma transformação que o daime faz na tua cabeça. É muito parecido com o conhecimento que a meditação traz. Traz também um conhecimento que pode te colocar dentro dos vários pontos do conhecimento espiritual. Não tem nenhuma explicação racional de como isso acontece, mas tem vários elementos da meditação que eu associo a o que eu 
recebia do daime. Um conhecimento que não tem tempo, não tem espaço, é universal, de energias, cármico, não somente racional.

É um conhecimento que vem das estrelas, do universo. Nós estamos inseridos aqui na Terra que tem uma energia espiritual densa, essas medicinas, esses veículos te conectam com uma outra vibração energética, com outra energia, isso acelera o processo de espiritualidade.

Por fim, outras perguntas realizadas aos entrevistados e que contribuem para que alcancemos o objeto dessa pesquisa, dizem respeito ao que os mesmos compreendem a partir de alguns conceitos usualmente utilizados pelos daimistas como, por exemplo, força e miração. De acordo com Groisman (1999), a miração é uma palavra usada para definir o estado de consciência no qual é possível ter contato com a espiritualidade ou percebê-la. A miração revela as experiências mais profundas da espiritualidade e pode "se manifestar na maneira de um insight sobre o cosmo, ou sobre o próprio eu. Pode ser uma visão, sons e cheiros que não fazem parte da situação em que se está, pode ser uma introdução em um outro universo, uma experiência cognitiva" (Groisman, 1999, p. 55). Um entrevistado relata que, para ele, miração é ter um insight e o que interessa é se essa informação é útil para seja para ele ou para a humanidade.

De maneira geral, os entrevistados relataram que as miraçóes são visóes que se tem mesmo de olhos fechados. Lembramos que as miraçóes devem também ser compreendidas a partir das categorias nativas e não devem ser consideradas simplesmente como alucinaçôes. Dois entrevistados articularam os conceitos de força e miração para explicar o que eles entendiam por isso. De acordo com esses entrevistados, a força "está ai", para todos, mas não a percebemos. Eles consideram essa força "a força da vida”, uma energia vital ou divina que está em todas as coisas que existem. Ao tomar o daime, a ideia é que nos abrimos para essa força e, assim, podemos ter visões de entendimento, vivências que podem ser emocionais ou visuais também. 
A miração eu entendo como um estado em que você se mescla com a força. É uma experiência, uma vivência e você não consegue separar o que é você, o que é a força. É como se tudo formasse uma substância só e aí você está naquela vivência, que pode ser emocional ou visual também.

A miração são visóes, como o daime é muito inteligente, muito esperto, ele faz coisas com a gente, entra no nosso organismo e uma das coisas que ele faz são essas visóes. Não tem como explicar elas, mas são visóes de entendimento assim. Tem coisas no daime que é só tomando daime, não tem como falar, é só quem vivencia mesmo.

Notamos aqui o fato de uma das pessoas entrevistadas atribuir o caráter de inteligência ao daime, o que nos aproxima da ideia supracitada de pensarmos o daime como um ser dotado de intencionalidade. Há ainda quem utilize conceitos não daimistas para explicar o que entende por miraçáo.

Miração é um conceito, assim, vou te dar uma explicação do budismo, bem racional. A meditação é uma forma de entrar em contato com a força, outra forma é no trabalho do daime. A gente entra em contato com uma energia mais refinada e essa energia é esse conhecimento, esse conhecimento transcendental. O contato com ela faz com que tu tenha um processo que te leva para outros caminhos de entendimento, te auxilia e entrar em contato com o mestre interno. Então a miração nada mais é que esse contato com essa energia superior.

Podemos ver, a partir dos relatos acima, que os entrevistados articulam concepçóes que provêm de religióes distintas, inclusive as que fazem parte da cosmologia daimista, para explicarem o seu ponto de vista sobre o daime. Entre elas, podemos citar a noção de espiritualidade. Groisman (1999) aponta que dentro do Santo Daime a noção da espiritualidade está articulada com a noção de doutrina e, juntas, estão associadas à compreensão de que a realidade tem duas dimensóes, o mundo material e o mundo espiritual, e que esses dois mundos se interpenetram. 
Deve-se considerar também que as trajetórias de sujeitos em "sociedades complexas" envolvem um intenso processo de articulação de categorias que não necessariamente encontram-se a priori no mesmo plano discursivo (Velho, 2003), são os sujeitos que a partir de suas experiências passam a produzir sentido para suas múltiplas vivências.

Dentro da cosmovisão daimista e como podemos ver nos relatos supracitados, os seres humanos não compreendem essa dualidade porque a ignoram e o daime é capaz de "expandir a consciência, mostrar uma lógica diferente, te conectar com uma outra energia". O processo de expansão de consciência induzido pelo daime aparece nas narrativas articulado com a ideia de autoconhecimento, constituindo assim uma possibilidade do sujeito reencontrar a divindade que habita dentro de si, fazendo com que esse sujeito possa "voltar a ser ele novamente" (Metzner, 2002, p. 20).

As noçóes que os ditos daimistas possuem do daime não necessariamente estão relacionadas ao Santo Daime e apontam para diversos sistemas religiosos - teístas e não teístas - e fazem sempre parte de uma concepção de base espiritual que, como aponta Groisman (1999), é semelhante àquela formulada por Allan Kardec. As narrativas daimistas adotam um conceito de que o espírito é um ser, uma entidade que evolui. Da mesma forma, compreendem o daime como um ser divino, uma "medicina da floresta" que age como facilitadora dessa evolução espiritual.

Ainda, os entrevistados também utilizam o conceito de carma e evolução espiritual, que estão presentes em diversas vertentes religiosas. Nenhum dos hinos do Santo Daime fala de carma, mas essa é uma concepção que faz parte da cosmovisão daimista. Para Groisman (1999, p. 52), as concepçôes de evolução espiritual e carma pressupóem "uma autoavaliação permanente na qual o indivíduo busca melhorar a sua conduta pessoal, tentando mudar seu comportamento tendo como parâmetro a ideologia e cosmovisão do grupo".

Um aspecto que chama a atenção nas narrativas coletadas é que podemos considerar que há, por parte dos entrevistados, uma maior relaçáo com o daime, propriamente falando, do que com o Santo Daime como religião. O Santo Daime possui um caráter híbrido devido à articulação de diversos sistemas 
religiosos dentro de uma mesma religiáo, mas, como supracitado, é o daime, uma entidade não humana, que articula as pessoas em um mesmo grupo.

Como vimos, para os daimistas, o daime aparece como um mediador, uma ferramenta que abre as pessoas a tipos específicos de conhecimentos como, por exemplo, conhecimentos de caráter ético, cognitivo, conhecimentos espirituais, entre outros. Ao mesmo tempo, esse mediador é considerado um ser espiritual, um ser senciente.

Portanto, partindo do pressuposto de o daime ser uma planta-mestre que pode ser considerada como uma fonte de conhecimento e, após o perfil do Santo Daime, bem como os dados referentes ao trabalho de campo e as narrativas dos entrevistados terem sido expostas, faz-se necessário que voltemos às nossas questóes iniciais. Se daime possui conhecimento, que tipo de conhecimento é esse? Ele se aproxima de alguma característica de conhecimento predefinido ou, ainda, pode ser considerado uma alternativa a essas tipificaçōes?

No que tange aos saberes proporcionados pelo daime, a singularidade desses processos de aprendizagem reside no fato desses saberes serem mediados por uma bebida que resulta da mistura de duas plantas. Contudo, como aponta Albuquerque (2012) esses saberes são compartilhados pelos humanos uma vez que o daime não ensina a si mesmo. Considerando essa reflexão, dentro dos moldes da ciência moderna um dos limites dos conhecimentos proporcionados pelo daime é que os critérios para sua avaliação e validação devem buscados dentro da própria experiência. Nos termos de Albuquerque (2012), é um saber vivido, ligado à experiência.

Entretanto, pensando nos termos do perspectivismo ameríndio, onde conhecer é dessubjetivar, tomar o ponto de vista do outro, náo é possível compreender um saber que está pautado em critérios de inteligibilidade xamânicos se as práticas utilizadas para essa compreensão não estiverem pautadas pelos mesmos critérios. É necessário que se estabeleça uma relação com aquilo que se procura conhecer. É necessário beber o daime caso queira aprender com ele e sobre ele. É apenas assim que esse conhecimento pode ser transmitido. 
Portanto, uma coisa é fornecer uma explicação científica dos efeitos do daime e como é que ela atua quimicamente, mas há, ainda, o aspecto da experiência que deve ser vivenciado. "O conhecimento científico dificilmente pode dar conta, sozinho, da maneira pessoal como a ayahuasca é vivida diferencialmente por cada sujeito" (Albuquerque, 2012, p. 26). De qualquer forma, o procedimento de tradução se mostra essencial ao tentarmos transmitir quais são esses saberes, o que eles fazem na vida e no mundo daqueles que tomam o daime.

Dadas as características expostas nas narrativas dos daimistas, podemos considerar que o conhecimento transmitido pelo daime aproxima-se da categoria de autoconhecimento. Entretanto, não podemos considerar a bebida exclusivamente como "fornecedora" de uma filosofia de autoconhecimento, já que existe toda uma dimensão moral, ética e social desde o ritual de ingestáo da mesma até a ação final daqueles que ingerem a bebida, considerando suas próprias motivaçôes e objetivos que o levaram até o Santo Daime.

Além disso, o conhecimento transmitido pelo daime configura também o que Albuquerque (2012) chama de inteligência existencial, sendo pensado como a fonte do conhecimento necessária para se viver corretamente tanto no aspecto moral e da conduta pessoal. Aqueles que bebem o daime são levados a refletir sobre si mesmos buscando a harmonia de suas relaçóes sociais e espirituais e, conforme a epistemologia indígena - que não se estrutura a partir de oposições binárias - esses saberes não se excluem mutuamente, mas podem ser considerados ao mesmo tempo medicinais, espirituais, sociais, morais, cognitivos, artísticos, entre outros.

Portanto, da mesma forma que na lógica xamânica, como aponta Viveiros de Castro (2015), há uma relação de interdependência entre todas as coisas (tudo sendo subjetivado), os conhecimentos que advém do daime - assim como apontados pelas narrativas dos daimistas em conjunto com os apontamentos de Albuquerque (2012) - também possuem esse caráter de interdependência. Trata-se, assim, de outra forma de conhecer, que não coincide com aquele conhecimento que se afirma na modernidade enquanto único conhecimento válido e universal. 


\section{CONSIDERAÇÓES FINAIS}

A ciência moderna é marcada por uma "ruptura ontológica entre ser humano e natureza" (Santos, 2009, p. 13), o que implica em dizer que no Ocidente há uma ideia de total separação entre natureza e ser humano, fator que desconsidera a possibilidade do daime poder ser um sujeito de conhecimento. Mas, por outro lado, dentro das lógicas xamânicas, todas essas espécies de sujeitos são centros de intencionalidade, ou seja, há uma dissoluçáo entre humanos e não humanos, que devem ser compreendidos a partir do mesmo campo sociocósmico.

$\mathrm{Na}$ compreensão de mundo daimista, como vimos, não há uma separação entre corpo e alma e há também a crença em um mundo espiritual. Assim, dentro dessa cosmologia e considerando a experiência proporcionada pelo daime, que está atrelada a critérios de inteligibilidade xamânicos, o pressuposto dessa bebida ser um sujeito de saber se mostra verdadeiro.

Uma epistemologia ayahuasqueira pressupóe que a efetividade dos aprendizados proporcionados pelo daime depende de determinados fatores, considerados pela ciência moderna como superstição, como a crença na espiritualidade. E essa crença tem consequências ou efeitos efetivos na vida daqueles que nelas acreditam. Para aqueles que ingerem o daime, por exemplo, os saberes provenientes dessa bebida são considerados como absoluta verdade e importam mais do que os saberes provenientes dos livros ou do saber científico.

Desses fatores resulta a incapacidade do paradigma científico de compreender estes saberes proporcionados pelo daime, principalmente ao estabelecer uma separação entre epistemologia e ontologia. Como apontam Santos, Nunes e Meneses (2004), compreender essas outras epistemologias nos obriga a compreender também a forma como se pensa do que é feito o mundo o que, por sua vez, nos obriga a pensar a própria separação moderna entre epistemologia e ontologia a partir da distinção histórica entre qualidades primárias e qualidades secundárias. As qualidades primárias são aquelas que dizem respeito à ontologia, a compreensão de como o mundo é, de que 
ele é feito; já as qualidades secundárias resultam da atividade humana, da intervenção humana, do modo de se conhecer e interagir com o mundo.

É importante apontar que não buscamos afirmar aqui que o conhecimento transmitido pelo daime é uma outra forma de conhecimento que substitua a do conhecimento científico. Não se trata de recusar ou negar o conhecimento científico, mas sim de enriquecê-lo com outras perspectivas que advém de outras cosmologias que também são válidas dentro de seus próprios contextos. A questão não é atribuir igual validade a todos os tipos de saber, mas "permitir uma discussão pragmática que não desqualifica $a$ priori tudo que seja diferente ao cânone epistemológico da ciência moderna" (Santos, 2002, p. 247), ou seja, criar uma inteligibilidade mútua entre experiências possíveis e disponíveis.

De maneira complementar, é importante trabalharmos com a ideia de que os diversos saberes são incompletos em si mesmos e que o diálogo epistemológico entre o paradigma científico e outras formas de conhecimento tem mais a adicionar do que subtrair nessas relaçôes. Ao substituirmos uma monocultura do saber por uma ecologia do saber, tornamos os saberes náo científicos complementares aos saberes científicos (Santos, 2008).

Podemos, portanto, considerar que os conhecimentos aprendidos a partir da ingestão do daime e as transformaçóes que ele causa na vida daqueles que o tomam, como relatado pelos daimistas, estão inseridos na concepção da sociologia das ausências apresentada por Santos (2008), ao tornar presentes percepçôes que são produzidas como inexistentes, irracionais ou supersticiosas pelo modelo global de racionalidade científica. Nesse trabalho, tendo como base essa sociologia das ausências, buscamos transformar a impossibilidade do daime ser considerado uma fonte de conhecimento, em algo inteligível, transformando assim a sua ausência em presença. 


\section{REFERÊNCIAS}

ALBUQUERQUE, Maria Betânia. Religião e educação: os saberes da ayahuasca no Santo Daime. Revista Brasileira de História das Religióes, Maringá, ano IV, n. 10, p. 149-173, maio 2011.

- Saberes da ayahuasca e processos educativos na religião do Santo

Daime. Revista Latinoamericana de Ciencias Sociales, Manizales, v. 10, n. 1, p. 351-365, 2012.

. Epistemologia da ayahuasca e a dissoluçáo das fronteiras natureza/ cultura da ciência moderna. Fragmentos de Cultura, Goiânia, v. 24, n. 2, p. 179-193, abr./jun. 2014.

ALVERGA, Alex Polari de (Org.). O Evangelho segundo Sebastião Mota. Boca do Acre: CEFLURIS Editorial, 1998.

AMARAL, Leila. Carnaval da alma: comunidade, essência e sincretismo na Nova Era. Petrópolis: Vozes, 2000.

ASSIS, Glauber de Loures; LABATE, Beatriz Caiuby. Dos igarapés da Amazônia para o outro lado do Atlântico: a expansão e internacionalizaçáo do Santo Daime no contexto religioso global. Religião e Sociedade, Rio de Janeiro, v. 34, n. 2, p. 11-35, 2014.

CEMIN, Arneide Bandeira. Os rituais do Santo Daime: sistemas de montagens simbólicas. In: LABATE, Beatriz Caiuby; ARAÚJO, Wladimir Sena (Org.). O uso ritual da ayahuasca. Campinas: Fapesp; Mercado de Letras, 2002. p. 275-310.

CSORDAS, Thomas. Corpo/significado/cura. Porto Alegre: Editora da UFRGS, 2008.

D'ANDREA, Anthony Albert Fischer. O self perfeito e a nova era: individualismo e reflexividade em religiosidades pós-tradicionais. São Paulo: Loyola, 2000. 
GOULART, Sandra Lúcia. O contexto de surgimento do culto do Santo Daime: formação da comunidade e do calendário ritual. In: LABATE, Beatriz Caiuby; ARAÚJO, Wladimir Sena (Org.). O uso ritual da ayahuasca. Campinas: Fapesp; Mercado de Letras, 2009. p. 277-302.

GROISMAN, Alberto. Eu venho da floresta: um estudo sobre o contexto simbólico do uso do Santo Daime. Florianópolis: Editora da UFSC, 1999. HERVIEU-LÉGER, Daniele. O peregrino e o convertido: a religião em movimento. Petrópolis: Vozes, 2008.

LA ROCQUE COUTO, Fernando de. Santos e Xamãs. 1989. Dissertação (Mestrado em Antropologia) - Universidade de Brasília, Brasília, DF, 1989.

LABATE, Beatriz Caiuby. A literatura brasileira sobre as religióes ayahuasqueiras. In: LABATE, Beatriz Caiuby; ARAÚJO, Wladimir Sena (Org.). O uso ritual da ayahuasca. Campinas: Fapesp; Mercado de Letras, 2002. p. 231-276. LABATE, Beatriz Caiuby; ARAÚJO, Wladimir Sena (Org.). O uso ritual da ayahuasca. Campinas: Fapesp; Mercado de Letras, 2009.

LABATE, Beatriz Caiuby; ROSE, Isabel Santana de; SANTOS, Rafael Guimarães dos. Religiōes ayahuasqueiras: um balanço bibliográfico. Campinas: Fapesp; Mercado de Letras, 2008.

LANDER, Edgardo. Ciências sociais: saberes coloniais e eurocêntricos. In: LANDER, Edgardo (Org.). A colonialidade do saber. Buenos Aires: CLACSO, 2005. p. 21-54.

LUNA, Luiz Eduardo. Xamanismo amazônico, ayahuasca, antropomorfismo e mundo natural. In: LABATE, Beatriz Caiuby; ARAÚJO, Wladimir Sena (Org.). O uso ritual da ayahuasca. Campinas: Fapesp; Mercado de Letras, 2002. p. 181-200. 
. Narrativas da alteridade: a ayahuasca e o motivo de transformação em animal. In: LABATE, Beatriz Caiuby; GOULART, Sandra Lúcia (Org.). $O$ uso ritual das plantas de poder. Campinas: Fapesp; Mercado de Letras, 2005. p. 333-354.

LUZ, Pedro. O uso ameríndio do caapi. In: LABATE, Beatriz Caiuby; ARAÚJO, Wladimir Sena (Org.). O uso ritual da ayahuasca. Campinas: Fapesp; Mercado de Letras, 2009. p. 37-68.

MARTINS, Paulo Henrique. As terapias alternativas e a libertação dos corpos. In: CAROZZI, María Julia (Org.). A Nova Era no Mercosul. Petrópolis: Vozes, 1999. p. 80-105.

METZNER, Ralph (Org.). Ayahuasca: alucinógenos, consciência e o espírito da natureza. Tradução de Márcia Frazão. Rio de Janeiro: Gryphus, 2002.

OLIVEIRA, Amurabi. Age of Aquarius. In: GOOREN, Henri (Org.). Encyclopedia of Latin American Religions. New York: Springer International Publishing, 2015. p. 1-5.

. A Nova Era com Axé: Umbanda Esotérica e Esoterismo Umbandista no Brasil. Revista Pós Ciências Sociais, São Luís, v. 11, n. 21, p. 167-183, 2014. SÁEZ, Oscar Calavia. Teorías, Actores y Redes de la Ayahuasca. Ilha: Revista de Antropologia, Florianópolis, v. 16, n. 1, p. 7-40, 2014.

SANTOS, Boaventura de Sousa. Para uma sociologia das ausências e uma sociologia das emergências. Revista Crítica de Ciências Sociais, Coimbra, n. 63, p. 237-280, out. 2002.

. A gramática do tempo: para uma nova cultura política. Sáo Paulo: Cortez, 2008.

. Um discurso sobre as ciências. São Paulo: Cortez, 2009. 
SANTOS, Boaventura de Sousa; NUNES, João Arriscado; MENESES, Maria Paula. Introdução: para ampliar o cânone da ciência: a diversidade epistemológica do mundo. In: SANTOS, Boaventura de Sousa (Org.). Semear outras soluçôes: os caminhos da biodiversidade e dos conhecimentos rivais. Porto: Ediçóes Afrontamento, 2004. p. 19-101.

SIQUEIRA, Deis. Novas religiosidades, estilo de vida e sincretismo brasileiro. In: SIQUEIRA, Deis; LIMA, Ricardo Barbosa de (Org.). Sociologia das adesóes: novas religiosidades e a busca místico-esotérica na capital do Brasil. Rio de Janeiro: Garamond; Vieira, 2003. p. 25-64.

TAVARES, Fátima. Alquimistas da cura: a rede terapêutica alternativa em contextos urbanos. Salvador: EDUFBA, 2012.

VELHO, Gilberto. Projeto e metamorfose: antropologia das sociedades complexas. Rio de Janeiro: Jorge Zahar Editor, 2003.

VIVEIROS DE CASTRO, Eduardo. Metafisicas canibais. São Paulo: Cosac Naify, 2015.

Recebido em: 23/04/17 Aprovado em: 12/07/17 



\title{
AS FACES DE DEUS: UM ESTUDO EXPLORATÓRIO COM CRIANÇAS E ADOLESCENTES ${ }^{1}$
}

\author{
Lorena Santos Ricardo ${ }^{2}$ \\ Antônio Carlos Ortega ${ }^{3}$ \\ Heloisa Moulin de Alencar ${ }^{4}$
}

Resumo: As representaçôes sobre Deus são elaboradas com o mesmo objetivo que o são todas as representações sobre as quais versa o conhecimento social (organizar, explicar e significar o que ocorre em seu meio). Assim, objetivou-se investigar as representaçôes de crianças e adolescentes acerca de Deus, por meio de entrevistas baseadas no método clínico piagetiano, com sujeitos de 6, 10 e 14 anos. Foram elaborados critérios para análise das repostas, baseados no trabalho de Delval e Muriá Vila (2008), de forma a permitir identificar diferentes níveis de elaboração dessa representação. Os resultados não apresentam diferenças relevantes entre as idades em relação ao nível da representação de Deus. Contudo, colaboram com as discussóes acerca da construção de tais representações. Novas pesquisas se fazem necessárias com um número maior de participantes e uma amostra mais

1 Os autores agradecem à Fundação de Amparo à Pesquisa e Inovação do Espírito Santo (FAPES) e à Coordenaçáo de Aperfeiçoamento de Pessoal de Nível Superior (CAPES) pelo apoio financeiro.

2 Mestre em Psicologia. Doutoranda em Psicologia pela Universidade Federal do Espírito Santo. Contato: lorena.sricardo@gmail.com

3 Pós-doutor em Psicologia. Professor Colaborador do Programa de Pós-Graduação em Psicologia da Universidade Federal do Espírito Santo. Contato: acortega@terra.com.br

4 Doutora em Psicologia Escolar e do Desenvolvimento Humano pela Universidade de São Paulo (2003). Professora Titular da Universidade Federal do Espírito Santo. Coordenadora do Laboratório de Psicologia da Moralidade (LAPSIM) da UFES. Pesquisadora Capixaba da Fundação de Amparo à Pesquisa e Inovação do Espírito Santo (FAPES), bolsa suspensa em março/2017. Bolsista da CAPES no Programa Estágio Sênior no Exterior em março/2017 (proc. no 88881.118916/2016-01) na University of California, Berkeley. Contato: heloisamoulin@gmail.com

Debates do NER, Porto Alegre, ano i8, N. 32, P. 233-258, JUl./Dez. 2017 
homogeneizada, a fim de identificar as variáveis que podem influenciar o processo de construção do conceito de Deus.

Palavras-chave: Conhecimento Social; Representação de Deus; Método Clínico.

\begin{abstract}
Representations about God are elaborated with the same purpose as are all representations about social knowledge (organizing, explaining and meaning what occurs in social environment). The objective was to investigate the representations of children and adolescents about God, through interviews based on the Piagetian clinical method, with subjects of 6,10 and 14 years old. Criteria for analysis of the answers were elaborated, based on the work of Delval and Muriá Vila (2008), in order to identify different levels of elaboration of this representation. The results do not present relevant differences between the ages about the level of God's representation. However, they collaborate with the discussions about the construction of such representations from the person that apprehends them and, actively, rework them. New research is needed with a larger number of participants and a more homogenized sample in order to identify the variables that can influence the process of building the concept of God
\end{abstract}

Keywords: Social Knowledge; Representation of God; Clinical Method. 


\section{INTRODUÇÃO}

Ao nascer, o homem não dispóe de seus instrumentos intelectuais completos, nem de representaçóes da realidade que o rodeia, portanto, precisa ir construindo ambos paralelamente, ao longo de seu desenvolvimento, a partir de um trabalho que é pessoal, mas possível apenas com ajuda dos outros. Há, assim, uma dialética entre o individual e o social que faz com que se desenvolvam mutualmente (Delval, 1989). A construção das representaçóes da realidade, incluindo nela o próprio sujeito e os outros, é, de acordo com Delval (2007), o maior legado da espécie humana. De fato, Piaget (2005) defende que uma das principais capacidades que os seres humanos possuem é a de construir representaçóes da realidade que o cerca, uma vez que o conhecimento do ambiente é uma forma essencial de adaptação ao meio.

O termo representação é empregado por Piaget (2005) em dois sentidos. Em uma definição mais ampla, representação abarca toda a inteligência de esquemas mentais. De forma mais restrita, faz referência à modelos mentais (evocação simbólica de realidades ausentes). A posição construtivista, baseada na teoria piagetiana, estabelece que não é possível ao sujeito conhecer a realidade tal como é sem a representar. Portanto, as representaçóes criadas são frutos tanto do que é socialmente transmitido quanto do que é construído pelo próprio do sujeito (Osti; Silveira; Brenelli, 2013). Logo, segundo autores que se fundamentam na abordagem piagetiana (Delval, 1992, 1994, 2007; Enesco et al., 1995; Denegri, 1998), os sujeitos elaboram representaçóes, apoiados sobre as estruturas cognitivas de que dispóem, a partir da própria experiência sobre os objetos que busca conhecer e das informaçóes recebidas das pessoas com quem convive, dos meios de comunicação e das instituiçôes sociais como família, escola e religião, por exemplo.

Essa última, podendo ser considerada uma das mais importantes, é capaz inclusive de gerar costumes e determinar comportamentos. Delval (2013, p. 26) aponta que a religião "é um fenômeno social de considerável complexidade e que está presente de alguma maneira em todas as sociedades, mas 
que também atende a necessidades diferentes, a diversas funções”. Pode, por exemplo, trazer conforto quando os homens são confrontados com eventos que fogem ao seu domínio e à sua capacidade de intervenção. Portanto, a religião exerce fascínio sobre o ser humano (Konings, 1997). Apesar deste não compreender completamente suas origens ou da ideia de Deus nela implicada, não consegue desvencilhar das curiosidades e questionamentos que ela provoca ou os quais procura responder.

Vergote (2001), defende que as pessoas que vivem nas sociedades formadas pela modernidade podem colocar-se fora da religiáo metodologicamente ou por convicção. Ou seja, nessas civilizaçóes, os homens têm o direito e a possibilidade cultural e social de crer ou de não crer naquilo que é pregado pela religiáo dissociada em seu contexto. Assim, eles podem, numa atitude científica, colocar-se do lado de fora da religiâo e estudá-la objetivamente. Nas palavras do autor:

Estudam-se filologicamente os textos sagrados, historicamente as igrejas, sociológica e psicologicamente a religião. A ciência é sem Deus, neutra com relação à fé religiosa; ela observa e explica o que pode. Isso não é ateísmo filosófico, mas ateísmo metodológico (Vergote, 2001, p. 15).

Vergote (2001), ao discutir o assunto, sob a ótica da Psicologia, assume essa atitude metodológica e indaga se a religião é, de fato, necessária para o bom funcionamento psicológico do homem. Argumenta que ela é, por excelência, um fenômeno propriamente humano e, paradoxalmente, não é uma construção puramente racional. E, como a Psicologia se propóe a estudar cientificamente aquilo que não é nem a lógica nem o corpo, a religião e, portanto, a representaçáo de Deus se constituem objetos de seu interesse.

Assim, sendo o Brasil um país religioso, com $86,8 \%$ da população declarando-se cristã - entre católicos e protestantes, segundo dados do Censo de 2010 divulgados pelo Instituto Brasileiro de Geografia e Estatística (2010) -, pesquisadores têm buscado compreender, do ponto de vista psicológico, o alcance da religião nas diversas áreas da vida humana. Dentre os estudos 
realizados no país, estão aqueles que investigam a influência religiosa no processo de enfretamento de doenças (Cerqueira-Santos; Koller; Pereira, 2004; Faria; Seidl, 2005; Panzini; Bandeira, 2007; Gobatto; Araujo, 2010; Duarte; Wanderley, 2011; Paiva, 1998), na saúde mental (Peres; Simão; Nasello, 2007; Dalgalarrondo, 2006, 2007, 2008; Menezes Jr.; Alminhana; Moreira-Almeida, 2012), na sexualidade (Silva et al., 2008), no que tange à qualidade de vida (Panzini et al., 2011), na dependência química (Dalgalarrondo et al., 2004; Silva et al., 2010; Pillon et al., 2011) e na educação (Paiva, 2006). Também há trabalhos, no campo da Psicologia, sobre a experiência e o desenvolvimento religioso (Amatuzzi, 1998a, 1998b, 1999, 2000, 2001), a religiosidade nos grupos de ajuda/apoio (Roehe, 2004; Lagercrantz, 2007), a experiência religiosa na religião institucionalizada (Mendonça, 2004), entre outros.

Outra representação fortemente influenciada pela religião é a ideia de Deus. De fato, apesar de ser diferente entre hinduístas, islamitas, judeus e cristãos, a representação sobre Deus traz consigo características específicas, já que são construídas fora do alcance da experiência (Delval; Muriá Vila, 2008), ou seja, não é possível agir sobre o Ser divino, apenas sobre seu conceito. Assim, para construir uma representação sobre Deus, independentemente de qual Deus seja, é necessário que haja uma transmissão social. Seja por meio de um ensino religioso sistemático, dos meios de comunicação, das trocas interindividuais, ou de qualquer outra forma de difusão, as representações sobre Deus sempre serão (re) construídas pelos sujeitos a partir de um elemento que é social.

Portanto, supóe-se que tais representaçóes, em alguma medida, podem fazer parte também do imaginário infantil. Delval e Muriá Vila (2008) assinalam que apesar de não serem produzidas espontaneamente em crianças pequenas, as ideias sobre Deus não são recebidas passivamente: são reelaboradas pelas crianças a partir das capacidades cognitivas de que dispóem. Além disso, Piaget (1970) afirma que as ideias vão sendo transformadas e sofisticadas na medida em que os sujeitos se desenvolvem, assim, pode-se inferir que o conhecimento sobre Deus é apreendido e representado de 
diferentes formas pelas crianças durante o processo de desenvolvimento. $\mathrm{Ou}$ seja, os sujeitos vão elaborando, ao longo desse processo, suas ideias sobre Deus, embasados nos instrumentos intelectuais de que dispóem e de forma compatível com o conjunto de crenças que compartilha (Delval, 1989).

Amatuzzi (2000, p. 17), ao ponderar sobre o desenvolvimento religioso, entendido como "o desenvolvimento pessoal no campo das indagaçóes por um sentido último (campo religioso)", estabeleceu como hipótese que os sujeitos passariam por nove etapas sucessivas, durante o seu percurso de vida. Para o autor, o desenvolvimento religioso se processa em paralelo com o desenvolvimento humano (tal qual proposto por Piaget) e, portanto, em cada etapa desse desenvolvimento, o sujeito encontra um desafio que precisa superar em direção ao sentido último. Baseando-se na teoria de Piaget (sobre o desenvolvimento cognitivo), nas pesquisas de Fowler (sobre os estágios da fé), na teoria de Kolberg (sobre o desenvolvimento moral) e em sua própria experiência como investigador do tema, Amatuzzi (2000) definiu essas etapas do desenvolvimento pessoal caracterizadas pelos seus desafios e experiências básicas.

Segundo Amatuzzi (2000), na 1. ${ }^{a}$ etapa ( 0 a 1,5 anos), o desafio central é descobrir um mundo independente do eu e a experiência básica ligada à superação deste desafio é a confiança estabelecida na relação com os pais. Essa confiança básica é o fundamento de todas as formas posteriores de fé ou religião. Na 2. ${ }^{a}$ etapa (2 a 6 anos), o desafio é abrir-se a uma relação onde o outro é aceito em sua separaçăo e autonomia. A experiência ligada à superação deste é a linguagem, enquanto reconstrução simbólica. A religião estará encontrando suas primeiras expressóes simbólicas concretas, a partir do que vai sendo recebido. Na 3. ${ }^{a}$ etapa ( 7 a 12 anos), O desafio é descobrir-se ativo e capaz. Sendo superado, desenvolve-se a auto segurança e a autoestima. A religiáo começa a se expressar agora através de histórias que condensam seu sentido. Na 4. ${ }^{a}$ etapa (13 a 18/20 anos), o desafio é descobrir uma verdade pessoal mais profunda e a experiência ligada à superação deste relaciona-se à escolha pessoal. Nesse momento, a religiáo, como parte da identidade recebida, tende a ser questionada. Na 5.a etapa (18/20 a 30 anos), o desafio é 
abrir-se para uma relação mais pessoal e profunda, associada à experiência de intimidade. A sustentação de uma postura religiosa diante da vida passa a ser condicionada a uma experiência pessoal, mais crítica e refletida. $\mathrm{Na} 6 .^{\mathrm{a}}$ etapa (30 a 35/40 anos) o desafio é gerar e cuidar. Se houver uma vivência religiosa autêntica, tende a se expandir criativamente no meio, em um sentimento de integração maior. Na 7.a etapa (35/40 a 60 anos), o desafio é superar rotinas e padróes assumidos, relativizando normas e papéis sociais, o que pode levar a uma fé mais pessoal, superando aspectos rígidos e estereotipados, ou então a um abandono da religião até então professada. Na $8 .^{\text {a }}$ etapa (60 a 80 anos), o desafio é aprofundar a libertação iniciada na etapa anterior. O sistema de orientação, religioso ou não, se relativiza. $\mathrm{O}$ conceito é vivido apenas como instrumento da experiência. $\mathrm{Na} 9 .^{\mathrm{a}}$ etapa (depois dos 80 anos), a última proposta por Amatuzzi (2000) acerca do desenvolvimento religioso, o desafio é passar da vida individual para algo radicalmente diferente, e entregar-se em paz nessa passagem. A preparação para a entrega absoluta, ou ela própria, se constitui no supremo ato religioso (ou implicitamente religioso quando a referência ao transcendente não é conceituada).

Os autores já citados Delval e Muriá Vila (2008) investigaram, a partir de uma abordagem piagetiana, no México e em Madri, como crianças de 6 a 15 anos, estudantes de colégios católicos, representam Deus, as origens e a morte. Ao discutir especificamente o desenvolvimento da representação de Deus, Delval e Muriá Vila (2008) o fazem a partir de cinco aspectos dessa representação: a concepçáo de Deus, o lugar onde Deus vive, as coisas sobre as quais Deus intervém, o poder de Deus e a comunicação com Deus. Os autores propóem que o desenvolvimento dessa representação pode ser considerado em três níveis distintos: o 1. o nível, "imagens fantásticas populares" (Delval; Muriá Vila, 2008, p. 27), vai até aproximadamente aos 10-11 anos, a concepção de Deus vincula-se estritamente com a ensinada pela religião; nesse nível, Deus é aquela imagem transmitida e adaptada à capacidade de compreensão dos sujeitos dessas idades, com traços humanos, semelhante às pessoas. $\mathrm{O} 2 .^{\circ}$ nível, "Deus torna-se independente dos homens" (Delval; Muriá Vila, 2008, p. 38), a partir dos 10-11, aproximadamente, até os 13-14 
anos, as representaçóes caminham para uma espiritualização de Deus, ainda que sua imagem tenha traços materiais. Nesse nível, contudo, começa-se a duvidar destes traços e começa-se a ver Deus como algo mais imaterial. O 3. ${ }^{\circ}$ nível, "um Deus abstrato e imaterial" (Delval; Muriá Vila, 2008, p. 48), a partir dos 13-14 anos, aproximadamente, Deus é concebido claramente como um ser imaterial. Deus passa a ser entendido como uma ideia interna, que tem a ver com a consciência dos indivíduos.

Uma pesquisadora que investigou a representação de Deus com crianças brasileiras, a partir de um enfoque piagetiano, foi Santos (2007). Em seu trabalho, a autora objetivou explorar como a concepção infantil sobre Deus evolui. Para tanto, solicitou a dez crianças de 7 e 11 anos que fizessem um desenho sobre Deus e utilizou um roteiro de entrevista semiestruturado para investigar a concepção de seus participantes. A partir da categorização das respostas, Santos (2007) observou que as crianças de 7 anos priorizaram, durante a entrevista, a moradia de Deus, suas funçóes, a concepção de um Deus punitivo e poderoso e também relacionaram Deus com a morte. Para as crianças de 11 anos, ressalta-se a ideia de Deus como criador, suas qualidades, a imagem de Deus como Pai e sua associação com a Bíblia. Em todas as categorias as crianças construíram a partir de ensinamentos religiosos de base cristã suas próprias concepções sobre a existência e a natureza de Deus. Santos (2007) assinala que a principal religião do ocidente (o cristianismo), sendo um desdobramento do judaísmo, é uma religião monoteísta que, entre seus ensinamentos, defende que Deus é um ser espiritual e pessoal, perfeito e santo. Também é concebido como o criador do universo, aquele que o conduz e governa. É um Ser constituído dos poderes de pensar, sentir, querer e, ainda mais, de consciência. $\mathrm{O}$ que, de certa forma, apareceu nos discursos de seus participantes.

O que fica claro nesses trabalhos (Amatuzzi, 2000; Santos, 2007; Delval; Muriá Vila, 2008) é que a ideia de Deus não é inata e não é estática, ela sofre alteraçóes na medida em que o indivíduo se desenvolve, amadurece, sendo influenciado com o que aprende em seu meio, e, nesse processo, aprende a dar significados, explicaçóes, diferentes para um mesmo fenômeno. $\mathrm{O}$ 
que se pode afirmar do ponto de vista psicogenético (Piaget, 1970, 2005) é que os sujeitos, no decurso do processo de desenvolvimento, têm seus instrumentos intelectuais alterados, modificados, lhes possibilitando pensar e construir representaçóes (incluindo aí as representações sobre Deus), de formas distintas, durante todo o processo.

Outros trabalhos sobre o tema que podem ser citados são o de Núñez (2012), desenvolvido em Bogotá, acerca das ideias infantis sobre Deus; o de Tamminen (1994) sobre a experiência com Deus na perspectiva de crianças e adolescentes finlandeses e o estudo realizado por Dickie et al. (1997) sobre a relação entre o relacionamento com o pai e a concepção de Deus de crianças norte americanas com idades entre 4 e 11 anos. $\mathrm{O}$ que há de acordo, na maioria dos estudos, é que as ideias sobre Deus que aprendem e desenvolvem as crianças parecem ser influenciadas pela cultura, pelas experiências delas com os adultos que compartilham sobre a fé e também pelos símbolos e ensinamentos da religião dominante em seu círculo social.

Como as representaçôes sobre Deus são elaboradas com o mesmo objetivo que o são todas as representaçôes sobre as quais versa o conhecimento social (organizar, explicar e significar o que ocorre em seu meio), e tendo em vista que as representaçóes de que dispóem os sujeitos influenciam inclusive a forma como agem e interagem no mundo social, objetivou-se investigar a concepção sobre Deus, de crianças e adolescentes, analisando, assim, sua (re) elaboração em diferentes momentos do processo de desenvolvimento, e verificar, se houver, diferenças e semelhanças entre crianças de diferentes idades, em relação a tais concepçôes.

\section{METODOLOGIA}

\section{Participantes}

Participaram da pesquisa 6 sujeitos, selecionados por conveniência (portanto, não se definiu religião, classe social, escolaridade), igualmente divididos quanto sexo, sendo dois de 6 anos, dois de 10 anos e dois de 14 
anos. Definiram-se três faixas etárias distintas (6, 10 e 14 anos) pela possibilidade de compreender três momentos distintos no processo desenvolvimento.

Como as concepçôes sobre Deus são construídas a partir da religião na qual se está inserido (Delval; Muriá Vila, 2008), importante ressaltar que os participantes tinham contato com a religião institucionalizada (cristianismo), frequentavam assiduamente as missas (ou cultos) e programaçóes da igreja. De fato, se autodeclararam católicos ou protestantes e afirmaram que eram levados aos eventos religiosos pelos pais, amigos da família e/ou familiares.

\section{Instrumentos e Procedimentos}

Primeiramente foi feito um contato com os responsáveis pelos participantes explicando o objetivo da pesquisa e solicitando que, caso concordassem com a participação do (a) filho (a), assinassem o Termo de Consentimento Livre e Esclarecido para Participação em Pesquisa. Em seguida, foi acordado com cada um o melhor local para realização da mesma. Assim, foi realizada a entrevista individual sobre representação de Deus, baseada no método clínico. Tomando por base o trabalho de Delval e Muriá Vila (2008), foram elaboradas 15 questóes que visavam investigar quatro diferentes aspectos da representação de Deus (1. Como Deus é, 2. Habitação de Deus, 3. Relacionamento com Deus e 4. Função de Deus). A entrevista foi registrada com um gravador digital e, posteriormente, transcrita para análise.

\section{Resultados e Discussão}

Os dados obtidos na entrevista permitiram a elaboração de quadros de organização e avaliação. Tais quadros abrigam os critérios de análise organizados segundo a sequência de perguntas do roteiro, elaborado em função dos quatro aspectos investigados na representação de Deus, e a frequência de respostas encontradas em cada um deles. Cada aspecto possui quadro específico, com critérios específicos. Isso se fez necessário uma vez que cada um deles investiga características e conteúdos diferentes, o que implica em quantidades diferentes de perguntas e, consequentemente, de critérios esta- 
belecidos para a análise. Os critérios de análise e níveis utilizados na análise das respostas foram baseados na proposta de Delval e Muriá Vila (2008).

Os critérios permitem avaliar o processo de desenvolvimento da representação de Deus, tal qual proposto por Delval e Muriá Vila (2008), em três níveis evolutivos que serão discutidos ao apresentar os dados. Importante observar que os quadros apresentam a frequência de resposta em todos os níveis, contudo serão discutidos apenas aqueles nos quais foram encontradas respostas dos participantes.

Além dos quadros, alguns trechos de entrevistas seráo apresentados durante as discussóes. Nestes, as falas dos entrevistados estarão em itálico para diferenciá-las das falas da pesquisadora. Esses trechos objetivam exemplificar as respostas consideradas em cada nível e ressaltar a qualidade do dado, a saber, a elaboração pessoal e íntima de cada sujeito acerca da própria concepçáo de Deus.

Dessa forma, os resultados serão apresentados separadamente em função dos quatro aspectos investigados na representaçáo de Deus: 1. Como é Deus, 2. Habitação de Deus, 3. Relacionamento com Deus e 4. Função de Deus.

As questóes que buscavam investigar o Aspecto 1, Como é Deus, referiam-se às características, qualidades e defeitos que os participantes atribuíam a Deus.

Os critérios de análise, então, foram delimitados para identificar os três Níveis de desenvolvimento da noção de Deus, no que concerne ao Aspecto 1. Assim, pode-se considerar uma resposta como Nível I quando: a. Descreve características antropomórficas, tal qual apresentadas em livros religiosos; b. Delimita o sexo masculino; ou c. Compreende Deus como uma pessoa, mas provida de perfeição e características excepcionais. A resposta é classificada no Nível II quando: d. Descreve características e referências a traços morais; e. Atribui ambos os sexos; ou f. Compreende Deus como uma pessoa, mas diferente dos humanos por sua natureza divina, embora também apresente defeitos. E, no Nível III, a resposta: g. Não descreve características antropomórficas; h. Não atribui sexo; ou i. Compreende 
Deus como uma ideia interna e pessoa. O Quadro 1 apresenta a frequência de respostas encontradas em cada nível.

Quadro 1 - Frequência das repostas sobre Como é Deus

\begin{tabular}{|c|c|c|c|}
\hline Níveis & $\mathbf{6}$ anos & $\mathbf{1 0}$ anos & $\mathbf{1 4}$ anos \\
\hline I & 4 & 3 & 4 \\
\hline II & 2 & 4 & 3 \\
\hline III & 0 & 1 & 0 \\
\hline
\end{tabular}

Fonte: Elaborado pelos autores.

Em relação ao Aspecto 1 da representação de Deus, a maioria das respostas dos participantes de 6 anos se concentra no Nível I; dos de 10 anos, nos níveis I e II, como também dos de 14 anos. Ao falar sobre as características de Deus, explicando como ele é, no Nível I os sujeitos descrevem Deus de forma mais material, com traços físicos humanos. Deus também é identificado como uma pessoa do sexo masculino, e isso se justifica tanto por seus traços masculinos (barba, bigode) quanto por seu nome ("se fosse mulher seria Deusa”, argumentou um participante). A seguir, os fragmentos das entrevistas exemplificam o que foi encontrado sobre essa questão.

Para você como é Deus? Poderia me explicar? - Eu acho que ele tem o cabelo até aqui (mostra os ombros), ai tem barba em volta, tem o olho preto e o nariz dele é meio pontudo e a bochech a assim (coloca as mãos apertando as bochechas) $e$ a boca assim (sorri). Você acha que Deus é uma pessoa ou não? - Acho que é. Deus é homem, mulher, os dois ou nenhum dos dois? - Homem. Por quê? - Porque ele tem... bigode, tem... tem um monte de coisas de homem. (Gabriela, 6 anos)

Para você como é Deus? - Uma pessoa que não é como a gente. É diferente. Como assim? Poderia me explicar? - Não dá. Não dá para explicar Deus. Então você acha que Deus é uma pessoa ou não? - É. Deus é homem, mulher, os dois ou nenhum dos dois? - Homem. Por quê? - Porque o nome já diz: "Deus". Se fosse mulher seria "Deusa". (Roger, 14 anos) 
As falas desses participantes estão em acordo com o exposto por Amatuzzi (2000) ao ponderar que, nas primeiras fases do que denomina desenvolvimento religioso, os símbolos religiosos já fazem algum sentido para a criança, mas este sentido ainda é vivenciado pela criança como algo externo a ela, ainda estritamente ligado aos conteúdos concretos das histórias que lhe são contadas.

No Quadro 1 é possível observar que participantes de todas as idades emitiram respostas classificadas como Nível II. Isso implica dizer que tais respostas contém a descrição de traços físicos, mas também apresentam uma análise que os ultrapassa, de certa forma, mostrando Deus como algo mais imaterial. A fala a seguir pode exemplificar:

Para você como é Deus? - Deus é tudo na minha vida. Poderia me explicar como você acha que Deus é? Como você O imagina? - Imagino que Ele seja bom, que ajuda todas as pessoas que pedirem a Ele. Você acha que Deus é uma pessoa ou não? - Mais ou menos. Ele tem corpo de uma pessoa, mas não daqui. Ele é do céu, não daqui. Deus é homem, mulher, os dois ou nenhum dos dois? - Os dois. Por quê? - Porque Ele é como um pai e como uma mãe, um irmão e uma irmã. Como você precisar, Ele é. (Kaio, 10 anos)

Kaio (10 anos) afirma que Deus tem um corpo de uma pessoa, "mas náo daqui", inferindo que é algo diferente. O que se comprova na ausência de traços antropomórficos ao descrever Deus, já apontando para uma característica de resposta de Nível III. Ou seja, respostas que explicam Deus de forma mais abstrata. Essa nuance de respostas de níveis diferentes emitidas pelo mesmo sujeito pode ser compreendida a partir dos trabalhos de Delval e Muriá Vila (2008) e Amatuzzi (2000) nos quais os autores discutem que, embora haja uma tendência em se prender a realidades externas, em determinado momento a relação estabelecida com a ideia de Deus náo é de mera passividade: o sujeito passa a significar sua experiência, ou seja, Deus é uma "pessoa", mas também é entendido com traços de personalidade ("bom", "ajuda as pessoas") e o sujeito ainda lhe atribui significado pessoal ("Deus é tudo na minha vida"). 
Ao falar sobre as qualidades e defeitos de Deus, os seis participantes afirmam que Deus tem qualidades. A bondade de Deus foi citada por todos, outras qualidades mencionadas referiam-se ao fato de Deus ter poder, abençoar e ser "legal". Apenas um participante, Kaio, de 10 anos, afirmou que Deus também tem defeitos, uma vez que, mesmo podendo evitar, ele permite que algumas pessoas o abandonem.

As questôes que investigavam sobre o Aspecto 2, Habitaçáo de Deus, referiam-se ao local onde Deus vive e com quem vive. Os critérios de análise delimitados visavam identificar os três níveis de desenvolvimento da noção de Deus, no que concerne ao Aspecto 2. Nesse sentido, ao falar sobre a habitação de Deus, a resposta pode ser considerada como Nível I quando: a. Identifica o céu (ou outro lugar concebido como material) como local da habitação de Deus; e/ou b. Afirma que Deus vive rodeado de personagens bíblicos e/ou familiares que já morreram. A resposta é classificada no Nível II quando: c. Indica que Deus está presente/vive de forma mais imaterial nas pessoas; e/ou d. Afirma que Deus vive sozinho. E, no Nível III, a resposta: e. Alega que, ao mesmo tempo em que náo vive em um lugar específico, Deus está em todos os lugares simultaneamente; e/ou f. Desconsidera a possibilidade de Deus viver só ou em companhia. O Quadro 2 destaca as respostas em cada nível.

Quadro 2 - Frequência das repostas sobre a Habitação de Deus

\begin{tabular}{|c|c|c|c|}
\hline Níveis & $\mathbf{6}$ anos & $\mathbf{1 0}$ anos & $\mathbf{1 4}$ anos \\
\hline I & 4 & 2 & 4 \\
\hline II & 0 & 2 & 0 \\
\hline III & 0 & 0 & 0 \\
\hline
\end{tabular}

Fonte: Elaborado pelos autores.

Em relação ao Aspecto 2 da representação de Deus, as respostas dos participantes de 6 e 14 anos se encontram no Nível I; dos de 10 anos, entre o Nível I e o Nível II. Sobre a Habitação de Deus, as respostas identificadas como Nível I referem-se a um lugar concreto, um espaço que pode ser 
delimitado, como o céu, por exemplo, como ensinado pela religião. Para a maioria dos participantes, Deus vive no Céu, e, sobre com quem vive são citados os anjos (em 4 respostas), Jesus (em 2 respostas), Maria (1 resposta) e familiares que já morreram (1 reposta).

Diferentemente dos dados aqui mencionados, em sua pesquisa sobre concepção de Deus, Santos (2007) constatou que a ideia de vincular Deus a um local preestabelecido (uma moradia) era mais comum em crianças menores.

No Nível II identificam-se as respostas que não delimitam um local específico, indicam que Deus está presente e/ou vive de forma mais imaterial nas pessoas. Embora ainda ligada à ideia de espaço, este, bem como o próprio Deus é concebido de forma mais imaterial e, sendo assim, Ele vive sozinho. A resposta de Helena pode exemplificar respostas classificadas como Nível II:

Você acha que Deus vive em algum lugar? - Não. Ele vive em lugar nenhum?

- É... por aí... Me explica isso então. - Ele vive em qualquer casa, nas pessoas. Ele vive só ou com alguém? - Ele vive sozinho. (Helena, 10 anos)

As questôes que objetivavam compreender o que os participantes pensavam sobre o Relacionamento com Deus, referiam-se a possibilidade de se relacionar com Deus, ao tipo de relacionamento estabelecido, a possibilidade de se comunicar com Deus e a possibilidade de resposta divina. Os critérios de análise delimitados para identificar o Nível I do Aspecto 3, são: a. A comunicação não é possível ou possível apenas por meio da oração; b. A comunicação gira em torno das orações aprendidas e os pedidos (coisas materiais concretas); c. Deus não responde ou responde concedendo o que lhe foi pedido; e/ou d. O relacionamento com Deus é impessoal. A resposta é classificada no Nível II quando: e. A comunicação é possibilitada pela oração e pelo pensamento; f. A comunicação relaciona-se às oraçôes aprendidas e aos pedidos (coisas não materiais); g. Deus responde por meio do pensamento, da alma ou coraçáo; e/ou h. O relacionamento é visto como pessoal. Nas respostas de Nível III: i. A comunicação é indireta e relaciona- 
se mais a uma reflexão moral e/ou confissão; j. A “comunicação” implica encontrar ajuda para pensar sobre as próprias ações ou tomar decisões; $\mathrm{k}$. Deus responde indiretamente, como uma ajuda na tomada de decisóes; 1 . O relacionamento implica um processo subjetivo de conversação consigo mesmo. O Quadro 3 apresenta a frequência de resposta em cada nível.

Quadro 3 - Frequência das repostas sobre o Relacionamento com Deus

\begin{tabular}{|c|c|c|c|}
\hline Níveis & $\mathbf{6}$ anos & $\mathbf{1 0}$ anos & $\mathbf{1 4}$ anos \\
\hline I & 6 & 5 & 6 \\
\hline II & 0 & 3 & 4 \\
\hline III & 0 & 1 & 0 \\
\hline
\end{tabular}

Fonte: Elaborado pelos autores.

Em relação ao Aspecto 3 da representação de Deus, a maioria das respostas dos participantes encontra-se no Nível I. Entretanto, os participantes de 6 anos apresentam respostas apenas de Nível I; os de 10 anos, de todos os níveis e os de 14 anos, apresentam respostas de Nível I e II. Sobre o Relacionamento com Deus, no Nível I estão as respostas que afirmam não acreditar na possibilidade de falar com Deus (por se tratar de um ser invisível), bem como aquelas que indicam a possibilidade de falar com Deus, através da reza ou oração, mas não acreditam que Deus responda, ou que Deus fale com as pessoas. Assim, o relacionamento com Deus (quando é apontada a possibilidade), é visto como impessoal, Deus é um ser distante, como ilustram os trechos a seguir:

Você acha que é possível falar com Deus? - Não. Por que não? - Porque Ele é invisivel. Você fala com Ele? - Não... E você acha que é possível ter um relacionamento com Deus? - Não. Ele mora longe, ele só fica no céu. (Igor, 6 anos)

Você acha que é possível falar com Deus? - Sim. Você fala com ele? - Sim. Como? - Orando, eu peço a ele as coisas que preciso. E você acha que Deus te responde? - Sim. Ele faz o que eu peço. (Helena, 10 anos) 
A explicação de Helena (10 anos) está em acordo com o que Oser e Gmünder (1991 apud Amatuzzi, 2000) observaram em seu estudo sobre os estágios do julgamento religioso: em determinado momento no curso do desenvolvimento, os sujeitos acreditam que é possível influenciar Deus por meio das preces, oraçôes, obediência às regras e etc. A prova dessa "influência", ou dessa interação com o divino, seria a resposta de Deus às oraçóes, o que se evidencia, na fala de Helena (10 anos), ao afirmar que Deus faz aquilo que ela pede.

No Nível II encontram-se as respostas que sinalizam a possibilidade de falar com Deus, por meio das oraçóes e do pensamento, bem como a possibilidade de resposta, sendo esta compreendida por meio do pensamento, da alma ou do coração. O relacionamento com Deus começa a ser visto, assim, como algo mais pessoal. Para os participantes (com exceção do Igor, de 6 anos) existe a possibilidade de se relacionar com Deus. Alguns disseram que é possível se relacionar com Deus como Pai (Kaio, de 10 anos, e Eliza, de 14 anos), os outros não identificaram um tipo específico de relacionamento, mas afirmaram que, com Deus, o relacionamento é melhor do que o relacionamento com as pessoas (Helena, de 10 anos) e que só com sinceridade é possível estabelecer esse relacionamento (Roger, de 14 anos). O trecho a seguir exemplifica as respostas encontradas nesse nível:

Você acha que é possível se relacionar com Deus? - Sim, porque Deus é como um pai. Ele cuida da gente, nos protege. E você acha que é possível falar com Deus? - Sim. Orando... E também no pensamento, assim, falando no seu pensamento o que está no seu coração. Você fala com Ele? - Falo... eu peço perdão pelos meus pecados, peço para cuidar da minha família, me abençoar, assim. E ele te responde? - Sim, mas não é algo que eu ouço, é algo que eu sinto. Eu não ouço a resposta, eu a sinto... (Eliza, 14 anos)

Entre os participantes, apenas Kaio (10 anos) apresentou resposta considerada de Nível III, por refletir, na oração, sobre o que deve fazer, sobre "o que é certo". 
Ele te responde? - Sim... mas não é assim. Não é ouvindo, eu sinto. Como? - Eu pergunto: Deus, você quer que eu faça isso? Eu devo fazer aquilo? Eu penso sobre o que devo fazer, então sinto a vontade dele. Eu náo ouço o que Ele diz, mas sinto no meu coração o que é certo. (Kaio, 10 anos)

Esse dado assinala certa disparidade em relação aos dados encontrados por Delval e Muriá Vila (2008), uma vez que esse tipo de resposta foi encontrado apenas entre participantes mais velhos (14 anos). Isso porque as respostas apontam para uma abstração maior, já que a comunicação é indireta e relaciona-se mais a uma reflexão moral e o relacionamento implica em um processo subjetivo de conversação consigo mesmo.

As questôes que buscavam investigar o Aspecto 4, Função de Deus versavam sobre o que Deus faz, se interfere na vida das pessoas, como interfere e apresentava um exemplo específico para que os participantes analisassem se e como, naquela situação, Deus interferiria.

Os critérios de análise, então, foram delimitados para identificar os três Níveis de desenvolvimento da noção de Deus, no que concerne ao Aspecto 4. Assim, pode-se considerar uma resposta como Nível I quando: a. Infere que Deus participa/interfere diretamente e concretamente em cada uma das coisas que acontecem no mundo; e/ou b. Atribui a Deus a responsabilidade de evitar que as pessoas se machuquem. A resposta é classificada no Nível II quando: c. Infere que Deus participa fundamentalmente nas coisas boas e age por meio dos sentimentos e pensamentos; e/ou d. Atribui a Deus a responsabilidade de manter as coisas em ordem. E, no Nível III, a resposta: e. Infere que Deus está consciente de tudo o que acontece, mas não intervém; e/ou f. Atribui a Deus a responsabilidade de criar as coisas para então funcionarem por si mesmas. O Quadro 4 apresenta a frequência de respostas em cada nível. 
Quadro 4 - Frequência das respostas sobre a Função de Deus

\begin{tabular}{|c|c|c|c|}
\hline Níveis & $\mathbf{6}$ anos & $\mathbf{1 0}$ anos & $\mathbf{1 4}$ anos \\
\hline I & 3 & 1 & 1 \\
\hline II & 1 & 2 & 2 \\
\hline III & 0 & 0 & 0 \\
\hline
\end{tabular}

Fonte: Elaborado pelos autores.

Em relação ao Aspecto 4 da representação de Deus, a maioria das respostas dos participantes de 6 anos se concentra no Nível I. Sobre a Função de Deus, o Nível I é caracterizado por respostas que atribui a Deus a função de evitar que as pessoas se machuquem ou se sintam infelizes. Além disso, inferem a Deus participação e interferência divina diretamente e concretamente em cada uma das coisas que acontecem no mundo. A interferência divina é vista de forma material, como se o próprio Deus se materializasse para intervir, como pode ser observado na fala da participante:

Para você, qual é a função de Deus, o que ele faz? - Ele ajuda as pessoas. Se a pessoa pediu uma coisa, e a pessoa rezar, ele faz. E eu acho que ele é o homem mais bonzinho do mundo. Você acha que Deus interfere ou não na vida das pessoas? - Eu acho que quando dois estão brigando, Deus interfere e fala assim: "para! por favor...". Como Deus fala com eles? - Ele chega e fala: "para!". E por que Deus faz isso? - Para os meninos não se machucarem. (Gabriela, 6 anos)

Sobre o que Deus faz, ou qual seria a função de Deus, os participantes falaram sobre "ajudar as pessoas" (4 respostas), "abençoar" (2 respostas), "salvar" (2 respostas), atender a pedidos/oraçôes (2 repostas), "ficar no céu" (1 resposta).

Em relação a esse aspecto, a maioria das respostas dos participantes de 10 e 14 anos, encontra-se no Nível II. Para estes, alguns conflitos como entre a bondade de Deus e a maldade percebida no mundo, ficam claros. Contudo, o conflito é resolvido de forma simples, como pontuam Delval e Muriá Vila (2008), ao indicar que Deus interfere apenas nas coisas boas. 
Além disso, Deus age por meio de pessoas que aconselham, bem como dos próprios sentimentos e pensamentos.

Você acha que Deus interfere ou não na vida das pessoas? - Sim. De que forma? - Se alguém está fazendo alguma coisa errada, ele coloca uma pessoa ali para dizer que aquilo está errado. (Roger, 14 anos)

Imagine que duas crianças estão brigando, uma é mais forte e está batendo muito na outra. Você acha que Deus interfere nessa situação? - Sim. De que forma? - Ele pode fazer assim... Dar um jeito na mente dele. Ai o outro pensa, ai depois Deus conversa e volta ao normal. (Helena, 10 anos)

Assim, ao inferir que pessoas veiculam a vontade de Deus, de alguma forma Roger (14 anos) percebe as pessoas como parte do mundo religioso. Deus, dessa feita, não está limitado apenas às histórias contadas pela religiāo, mas ele "fala", "age" no sujeito, como aponta Helena (10 anos), e por intermédio do sujeito, como aponta Roger (14 anos). O que também foi constatado por Oser e Gmünder (1991 apud Amatuzzi, 2000).

\section{CONSIDERAÇÓES FINAIS}

As ideias sobre Deus, advindas dos diversos segmentos da sociedade na qual a criança está inserida, são assimiladas por ela de diferentes formas ao longo do processo de desenvolvimento, conforme apontado por Santos (2007), Delval e Muriá Vila (2008), Amatuzzi (2010), entre outros. Essa pesquisa, portanto, colabora para a discussão da construção de tais ideias a partir do sujeito que as apreende e, de forma ativa, as reelabora. Também confirma as contribuiçóes do método clínico na investigação do conceito de Deus e evidencia a possibilidade de utilização dos critérios baseados no trabalho de Delval e Muriá Vila (2008) para análise desse conceito.

Nos resultados obtidos, diferente do esperado, considerando a pesquisa de Delval e Muriá Vila (2008), não foram constatadas semelhanças e diferenças relevantes entre as idades, aparecendo, entretanto, uma diferença qualitativa nas respostas de Kaio (10 anos) por serem mais elaboradas, 
inclusive, que as dos participantes mais velhos. Essa disparidade, contudo, aponta para certa limitação do estudo, que, selecionando os participantes por conveniência, acabou por impossibilitar a identificação e discussão das possíveis influências nesse resultado.

Portanto, novas pesquisas se fazem necessárias, com um número maior de participantes e uma amostra mais homogeneizada, a fim de identificar outras variáveis que podem influenciar o processo de construção do conceito de Deus, bem como outros conceitos (como justiça, honra e generosidade) que podem ser influenciados por ele.

\section{REFERÊNCIAS}

AMATUZZI, Mauro Martins. Experiência religiosa: busca de uma definição. Estudos de psicologia, Campinas, v. 15, n. 1, p. 49-65, 1998a.

. A experiência religiosa: estudando depoimentos. Estudos de psicologia, Campinas, v. 15, n. 2, p. 3-27, 1998 b.

. Religião e sentido de vida: um estudo teórico. Temas em Psicologia, Ribeirão Preto, v. 7, n. 2, p. 183-190, 1999.

. O desenvolvimento religioso: uma hipótese psicológica. Estudos de psicologia, Campinas, v. 17, n. 1, p. 15-30, 2000. Disponível em: <http://www.scielo.br/pdf/estpsi/v17n1/02.pdf>. Acesso em: 9 ago. 2014.

. Esboço de teoria do desenvolvimento religioso. In: PAIVA, Geraldo José de (Org.). Entre necessidade e desejo: diálogos da psicologia com a religião. São Paulo: Ediçóes Loyola, 2001. p. 25-52.

CERQUEIRA-SANTOS, Elder; KOLLER, Sílvia Helena; PEREIRA, Maria Teresa Lisboa Nobre. Religião, saúde e cura: um estudo entre neopentecostais. Psicologia: Ciência e Profissão, Brasília, DF, v. 24, n. 3, p. 82-91, 2004. Disponível em: <http://www.scielo.br/scielo.php?script=sci_arttext \&pid=S1414-98932004000300011\&lng=pt\&tlng=pt.10.1590/S141498932004000300011>. Acesso em: 4 ago. 2014. 
DALGALARRONDO, Paulo. Relações entre duas dimensões fundamentais da vida: saúde mental e religião. Revista Brasileira de Psiquiatria, São Paulo, v. 28, n. 3, p. 177-178, set. 2006. Disponível em: <http://www.scielo.br/scielo. php?script=sci_arttext\&pid=S1516-44462006000300006\&lng=pt\&tlng=pt. \%2010.1590/S1516-44462006000300006>. Acesso em: 4 ago. 2014.

. Estudos sobre religião e saúde mental realizados no Brasil: histórico e perspectivas atuais. Revista de Psiquiatria Clínica, São Paulo, v. 34, supl. 1, p. 25-33, 2007. Disponível em: <http://www.scielo.br/scielo.php?script= sci_arttext\&pid=S0101-60832007000700005\&lng=pt\&tlng=pt. 10.1590/ S0101-60832007000700005>. Acesso em: 4 ago. 2014.

. Religião, psicopatologia e saúde mental. Porto Alegre: Artmed, 2008.

DALGALARRONDO, Paulo et al. Religião e uso de drogas por adolescentes. Revista Brasileira de Psiquiatria, São Paulo, v. 26, n. 2, p. 82-90, 2004. Disponível em: <http://www.scielo.br/scielo.php?script=sci_arttext \&pid=S1516-44462004000200004\&lng=pt\&tlng=pt. 10.1590/S151644462004000200004>. Acesso em: 4 ago. 2014.

DELVAL, Juan. La representación infantil del mundo social. In: TURIEL, Elliot; ENESCO, Ileana; LINAZA, Josetxu (Org.). El mundo social en la mente infantil. Madrid: Alianza, 1989. p. 245-328.

. El constructivismo y la adquisición del conocimiento social. Apuntes de Psicología, Sevilla, n. 36, p. 5-24, 1992.

. El desarrollo humano. Madrid: Siglo XXI, 1994.

- Aspectos de la construcción del conocimiento sobre la sociedad. Educar em revista, Curitiba, v. 23, n. 30, p. 45-64, 2007. Disponível em: <http:/www.scielo.br/pdf/er/n30/a04n30.pdf>. Acesso em: 28 maio 2014.

. O desenvolvimento psicológico humano. São Paulo: Vozes, 2013.

DELVAL, Juan; MURIÁ VILA, Irene. Los niños y Dios: ideas infantiles sobre la divindade, los orígenes y la muerte. Ciudad de México: Siglo XXI, 2008. 
DENEGRI, Marianella. La construcción de nociones económicas en la infancia y adolescencia. In: BAYONA, Jesús Ferro; AMAR, José Juan; LLANOS, Raimundo Abello (Ed.). Desarrollo humano: perspectivas siglo XXI. Barranquilla: Ediciones Uninorte, 1998.

DICKIE, Jane R. et al. Parent-child relationships and children's images of God. Journal for the Scientific Study of Religion, v. 36, n.1, p. 25-43, mar. 1997.

DUARTE, Flávia Meneses; WANDERLEY, Kátia da Silva. Religião e espiritualidade de idosos internados em uma enfermaria geriátrica. Psicologia: teoria e pesquisa, Brasília, DF, v. 27, n. 1, p. 49-53, jan./mar. 2011.

ENESCO, Ileana et al. La comprensión de la organización social en niños y adolescentes. Madrid: Cide, 1995.

FARIA, Juliana Bernardes de; SEIDL, Eliane Maria Fleury. Religiosidade e enfrentamento em contextos de saúde e doença: revisão da literatura. Psicologia: reflexão e crítica, Porto Alegre, v. 18, n. 3, p. 381-389, 2005.

GOBATTO, Caroline Amado; ARAUJO, Tereza Cristina Cavalcanti Ferreira de. Coping religioso-espiritual: reflexôes e perspectivas para a atuação do psicólogo em oncologia. Revista da SBPH, Rio de Janeiro, v. 13, n. 1, p. 52-63, jun. 2010.

INSTITUTO BRASILEIRO DE GEOGRAFIA E ESTATÍSTICA (IBGE). Censo demográfico 2010: características gerais da população, religião e pessoas com deficiência. Rio de Janeiro: IBGE, 2010.

KONINGS, Johan M. H.; ZILLES, Urbano (Org.). Religião e cristianismo. Porto Alegre: EDIPUCRS, 1997.

LAGERCRANTZ, Luciana Neves. A experiência religiosa no grupo dos alcoólicos anônimos. 2007. 76 f. Monografia (Graduação em Psicologia) - Centro Universitário de Brasília, Brasília, DF, 2007. 
MENDONÇA, Antônio Gouvêa. A experiência religiosa e a institucionalização da religião. Estudos Avançados, São Paulo, v. 18, n. 52, p. 29-46, 2004. Disponível em: <http://www.scielo.br/scielo.php?script=sci_arttext \&pid=S0103-40142004000300004\&lng=en \& $\operatorname{lng}=$ es. 10.1590/S010340142004000300004>. Acesso em: 9 ago. 2014.

MENEZES JR., Adair; ALMINHANA, Letícia; MOREIRA-ALMEIDA, Alexander. Perfil sociodemográfico e de experiências anômalas em indivíduos com vivências psicóticas e dissociativas em grupos religiosos. Revista de Psiquiatria Clinica, São Paulo, v. 39, n. 6, p. 203-207, 2012. Disponível em: <http://www.scielo.br/scielo.php?script=sci_arttext\& pid=S0101-60832012000600005\&lng=pt\&tlng=pt.10.1590/S010160832012000600005>. Acesso em: 4 ago. 2014.

NÚNEZ, César Fernando Franco. La experiencia de Dios en la infancia. Reflexiones Teológicas, n. 9, p. 57-72, enero/jul. 2012. Disponível em: $<\mathrm{http}$ //dialnet.unirioja.es/ servlet/articulo?codigo $=4087616>$. Acesso em: 4 ago. 2014.

OSTI, Andréia; SILVEIRA, Cristina Andrade Ferreira; BRENELLI, Rosely Palermo. Representaçóes sociais: aproximando Piaget e Moscovici. Schème: Revista Eletrônica de Psicologia e Epistemologia Genéticas, v. 5, n. 1, p. 35-60, 2013. Disponível em: <http://www2.marilia.unesp.br/ revistas/index. php/scheme/ article/view/3176>. Acesso em: 4 ago. 2014.

PAIVA, Geraldo José de. O Estado e a educação religiosa: observações a partir da psicologia. Psicologia: Teoria e Pesquisa, Brasília, DF, v. 22, n. 1, p. 63-67, jan./abr. 2006. Disponível em: <http://www.scielo.br/scielo.php? script=sci_arttext \&pid=S0102-37722006000100008\&lng=pt\&tlng=pt. 10.1590/S0102-37722006000100008>. Acesso em: 4 ago. 2014.

. AIDS, psicologia e religião: o estado da questão na literatura psicológica. Psicologia: Teoria e Pesquisa, Brasília, DF, v. 14, n. 1, p. 27-34, 1998. 
PANZINI, Raquel Gehrke; BANDEIRA, Denise Ruschel. Coping (enfrentamento) religioso/espiritual. Revista de Psiquiatria Clínica, São Paulo, v. 34, supl. 1, p. 126-135, 2007. Disponível em: <http://www.scielo.br/scielo. php?script=sci_arttext\&pid=S0101-60832007000700016\&lng=pt\&tlng=pt. 10.1590/S0101-60832007000700016>. Acesso em: 4 ago. 2014.

PANZINI, Raquel Gehrke et al. Validação brasileira do Instrumento de Qualidade de Vida/espiritualidade, religião e crenças pessoais. Revista de Saúde Pública, São Paulo, v. 45, n. 1, p. 153-165, 2011. Disponível em: <http://www.scielo.br/scielo.php?script=sci_arttext\&pid= S0034-89102011000100018\&lng=pt\&tlng=pt.\%2010.1590/S003489102011000100018>. Acesso em: 4 ago. 2014.

PERES, Julio Fernando Pietro; SIMÃO, Manoel José Pereira; NASELLO, Antonia Gladys. Espiritualidade, religiosidade e psicoterapia. Revista de Psiquiatria Clínica, São Paulo, v. 34, supl. 1, p. 136-145, 2007. Disponível em: <http://www.scielo.br/scielo.php?script=sci_arttext\&pid= S0101-60832007000700017\&lng=pt\&tlng=pt.10.1590/S010160832007000700017>. Acesso em: 4 ago. 2014.

. A construção do real na criança. Rio de Janeiro: Zahar, 1970.

PIAGET, Jean. A representação do mundo na criança. São Paulo: Idéias \& Letras, 2005.

PILLON, Sandra Cristina et al. Uso de álcool e espiritualidade entre estudantes de enfermagem. Revista da Escola de Enfermagem da USP, São Paulo, v. 45, n. 1, p. 100-107, mar. 2011. Disponível em: <http://www.scielo.br/ scielo.php?script=sci_arttext\&pid=S0080-62342011000100014\&lng=pt\& tlng=pt.\%2010.1590/S0080-62342011000100014>. Acesso em: 4 ago. 2014. 
ROEHE, Marcelo Vial. Experiência religiosa em grupos de auto-ajuda: o exemplo de neuróticos anônimos. Psicologia em Estudo, Maringá, v. 9, n. 3, p. 399-407, set./dez. 2004. Disponível em: <http://www.scielo.br/ scielo.php?script=sci_arttext\&pid=S1413-73722004000300008\&lng=en\& tlng=pt.\%2010.1590/S1413-73722004000300008>. Acesso em: 9 ago. 2014.

SANTOS, Elaine Franciny. A noção de Deus em crianças. 2007. 51 f. Monografia (Graduação em Psicologia) - Centro Universitário do Leste de Minas Gerais, Ipatinga, 2007.

SILVA, Cristiane Gonçalves da et al. Religiosidade, juventude e sexualidade: entre a autonomia e a rigidez. Psicologia em Estudo, Maringá, v. 13, n. 4, p. 683-692, out./dez. 2008. Disponível em: <http://www.scielo.br/ scielo.php?script=sci_arttext\&pid=S1413-73722008000400006\&lng=pt\& tlng=pt.\%2010.1590/S1413-73722008000400006>. Acesso em: 4 ago. 2014.

SILVA, Cristiane Schumann et al. Relação entre prática religiosa, uso de álcool e transtornos psiquiátricos em gestantes. Revista de Psiquiatria Clínica, Sáo Paulo, v. 37, n. 4, p. 152-156, 2010. Disponível em: <http://www.scielo.br/ scielo.php?script=sci_arttext\&pid=S0101-60832010000400002\&lng=pt\& tlng=pt.\%2010.1590/S0101-60832010000400002 >. Acesso em: 4 ago. 2014.

TAMMINEN, Kalevi. Religious experiences in childhood and adolescence: a viewpoint of religious development between the ages of 7 and 20. The International Journal for the Psychology of Religion, v. 4, n. 2, p. 61-85, 1994. VERGOTE, Antoine. Necessidade e desejo da religiấo na ótica da psicologia. In: PAIVA, Geraldo José de (Org.). Entre necessidade e desejo: diálogos da psicologia com a religiáo. São Paulo: Ediçóes Loyola, 2001. p. 9-24.

Recebido em: 18/11/2016

Aprovado em: 03/07/2017 


\section{AS MUITAS FACES DE NOSSA SENHORA DOS REMÉDIOS}

\section{Lidice Meyer Pinto Ribeiro ${ }^{1}$}

Resumo: Através da análise da iconografia de Nossa Senhora dos Remédios, o objetivo deste trabalho é identificar a difusão desta devoção e suas características marcantes e diferenciadoras no que tange a sua íntima correlação com o ideal de libertação de cativos. Para tanto realizou-se pesquisas de campo na França, Espanha, Portugal, Itália (Roma, Arquivos Secretos do Vaticano) e em diversos locais do Brasil, sempre em busca de imagens representativas de Nossa Senhora dos Remédios. Observou-se que a mudança ocorrida na devoção do século XII ao século XXI pode ser percebida através das alteraçôes sofridas pelas representaçóes físicas desta invocação.

Palavras-chave: Nossa Senhora dos Remédios. Ordem da Santíssima Trindade e Redenção de Cativos. Trinitários. Nossa Senhora do Leite.

Abstract: This paper analyse the spread of Our Lady of Good Remedy's devotion and its distinguishing characteristics in relation to its intimate correlation with the ideal of captive liberation. through its iconography In orther to obtain this, the research was carried out in France, Spain, Portugal, Italy (Rome, Vatican Secret Archives) and in various places in Brazil, always searching for representative images of Our Lady of Good Remedy. It was observed that the change in devotion from the twelfth to the twenty-first century can be perceived through the changes undergone by the physical representations of this invocation.

Keywords: Our Lady of Good Remedy. Order of Saint Trinity and Redemption of Captives. Trinitarians. Our Lady of the Milk.

1 Pós-doutoranda em Estudos de Globalização pela Universidade Aberta de Lisboa/ CLEPUL. Pós-Doutora em Antropologia e História pela Universidade de Sáo Paulo. Doutora em Antropologia Social pela mesma Universidade. Docente do Programa de Pós-Graduação em Ciências da Religiáo da Universidade Presbiteriana Mackenzie. Contato: lidice.ribeiro@mackenzie.br 


\section{INTRODUÇÃO}

Segundo Megale (2008, p. 16), as primeiras imagens de Maria foram as Virgens Orantes das Catacumbas, representadas sempre em pé, com os braços abertos. Teria sido apenas após o Concílio de Calcedônia, em 451 d.C., que defendeu ser Maria a "portadora de Deus" ou "mãe de Deus"2 (Theotókos) que as imagens de Nossa Senhora começaram a ser diversificadas e cada vez mais difundidas.

Achados arqueológicos do período Paleolítico, porém, mostram a existência de divindades femininas representadas através de esculturas e pinturas simbolizando a fertilidade e a sacralidade da vida na Grande Mãe. Desde os seus primórdios, o homem já demonstrava uma veneraçáo especial pela figura feminina. A religiáo refletia a importância da mulher como fonte de fertilidade e preservação da vida.

Alguns autores, como Chiavenato (2002), apontam para uma correlação simbólica entre a devoção a Maria e a crença mitológica na Grande Mãe, que teria sido assimilada pelos cristáos primitivos na figura da Virgem. Nas regiốes do antigo império romano, restam alguns indícios desta correlaçáo, sendo alguns deles relacionados no estudo Origens Orientais da Religiáo Portuguesa, de Moisés Espírito Santo, e em As religióes da Lusitânia ${ }^{3}$, de Leite Vasconcelos. Carvalhinhos (2005, p. 165) considera que "a figura de Maria é um símbolo ou um arquétipo da Grande Mãe, ou das antigas divindades pagãs" apontando para o fato da valorização de Nossa Senhora ser uma "manobra de sucesso, por parte da Igreja Católica, para consolidar seu poder no Império Romano, através da criação de um símbolo feminino divino".

2 “...nosso Senhor Jesus Cristo.... gerado, segundo a divindade, antes dos séculos pelo Pai e, segundo a humanidade, por nós e para a nossa salvaçáo, gerado da Virgem Maria, mãe de Deus (Theotókos)" (Concílio de Calcedônia, Actio V. Mansi, VII, 116s. In: BETTENSON, H. Documentos da Igreja Cristã. São Paulo: ASTE, 1998. p. 101).

3 VASCONCELOS, José Leite de. Religiōes da Lusitânia. Lisboa: Imprensa Nacional, 1988-1989. 
Moisés Espírito Santo (1988, p. 29) classifica o culto mariano através de duas designaçóes: tópico, quando se relaciona a uma determinada povoação ou lugar, caracterizando a devoção como "protetora ou fundadora de um grupo étnico ou territorial”, ou quanto à funçâo da invocação: "Nossa Senhora tem de ter um nome particular, de outro modo não existe, não tem personalidade própria, e, portanto, náo pode agir”. Para esse autor, portanto, as devoçóes a Nossa Senhora estáo fortemente ligadas a uma localidade como no caso de Nossa Senhora de Fátima, por ter aparecido na cidade deste nome, ou, a uma referência direta a uma característica ou qualidade de Maria, como "das dores", "da saúde" etc.

O progresso do papel da iconografia cristã está intimamente ligado ao desenvolvimento do cristianismo. Em seus primórdios, a figura de Cristo era representada por símbolos como pão e vinho, cordeiro ou peixe. Foi só a partir do final do século III que começam a representar Jesus com figura humana nas catacumbas. Foi especialmente com a afirmação da humanidade de Cristo e o desenvolvimento do culto à sua mãe que houve um impulso ao desenvolvimento de uma cultura visual cristã.

Se a Igreja conferiu um papel crescente às imagens no culto e na devoção, foi porque as imagens, mais do que a palavra dos pregadores (a leitura dos livros não sendo acessível senão a uma pequena minoria), exercia sobre a imaginação dos fiéis uma ação decisiva considerada benéfica (Schmitt, 2007, p. 353).

Dentro de uma sociedade, em sua maioria composta por analfabetos, sem acesso ao estudo da Bíblia por si só, criou-se naturalmente uma "religião das imagens". A imagem se tornaria uma fonte de inspiração para o fiel, mas também de ensino. É dentro desta perspectiva que o culto às imagens foi transladado de Portugal para as suas colônias.

A importância da iconografia nas missóes católicas no Novo Mundo é bem expressa por uma carta datada de 1633, onde o frei Gabriel do Espírito 
Santo, missionário da Ordem Franciscana no Brasil solicita uma licença especial para a importação de imagens e de relíquias de santos ${ }^{4}$.

O catolicismo denominado santorial (Camargo, 1973, p. 32) tem como característica o culto aos santos, e é uma das formas mais tradicionais de catolicismo presente no Brasil desde o período da colonizaçáo. "É um catolicismo leigo, não apenas pela escassez histórica do clero, mas pela própria estrutura da experiência religiosa em que se baseia" (Antoniazzi, 1989, p. 14). Foi este tipo de culto que marcou a dinâmica religiosa do Brasil colonial, com caráter predominantemente leigo, seja nas irmandades, confrarias, como nos oratórios particulares, capelas de sítio ou de beira de estradas.

Os santos penetram na vida dos que os veneram, misturando-se com seus problemas, suas necessidades mais urgentes, nos negócios, na vida familiar, nos casamentos, nos amores. E tudo isso sem cerimônia, sem se precisar de apresentação, sem intermediário. Tudo se passa entre o santo e seu devoto (Rolim, 1976, p. 159).

Nesse sentido há, da mesma forma que ocorre com os santos, a identificação de características e "poderes" atribuídos à mãe de Jesus e às necessidades do cotidiano, dando origem às diversas invocaçôes de Marias. Muitas destas invocaçóes foram táo bem aceitas dentro da religiosidade popular que

4 Archivio Romano di Propaganda Fide, Scritture originali riferite nelle Congregazioni Generai, cod. 260, f. 283 apud DELL'AIRA, Alessandro. Le navire de la reine et du sainte esclave de la Mediterranée au Brésil. Cahiers de la Méditerranée, Nice, n. 65, p. 329-339, 2002. p. 338.

5 A Igreja Católica Romana orienta os devotos a distinguirem os cultos a Deus, a Maria e aos Santos, dando a estes designaçôes diferentes. O culto de latria (adoração) deveria ser prestado apenas a Deus (Santíssima Trindade), aos santos deve-se prestar veneraçáo (culto de dulia) e a Maria, admite-se um culto intermediário (hiperdulia), maior que uma veneração, mas sem ser adoração. Apesar destas orientaçóes canônicas, o catolicismo popular não distingue estes três tipos de culto, fazendo separaçáo apenas entre o culto a Deus (não imagético) e o culto a Jesus, ao Divino Espírito Santo, a Maria e aos Santos (aproximados aos fiéis através de imagens).

Debates do NER, Porto Alegre, ano i 8, N. 32, P. 259-287, JUl./Dez. 20 I7 
acabaram por adquirir personalidade própria, como que separada da pessoa de Maria. É comum encontrarmos diversas imagens de diferentes devoçôes marianas como Nossa Senhora de Fátima e Nossa Senhora Aparecida, ocupando lugar lado a lado nos altares e oratórios particulares ou em igrejas, e recebendo invocaçôes e devoçóes próprias, como se representassem santas diferenciadas. Muitas vezes, dentro do imaginário popular, estas devoçóes se distanciam da associação com a figura da mãe de Jesus. No imaginário do fiel, as imagens que trazem o menino Jesus ao colo e a de Nossa Senhora das Dores, estas sim, representam a "mãe de Deus". As demais, vão aos poucos se distanciando de sua origem, adquirindo histórias próprias, oraçóes próprias e fieis próprios. As invocaçóes que Maria recebe individualizam, particularizam e criam em elo afetivo maior entre a comunidade e o alvo da devoção.

"São tantos os títulos que a Santa Igreja ou a devoção, a piedade, a gratidão e a confiança dos fiéis deram à mãe de Deus que de muitos deles nem todos sabem a origem" (Aducci, 2003, p. 11). Estudando estes títulos, Aducci classifica alguns como litúrgicos e outros como históricos, situando-os por ordem de aparição do século I ao século XX. Em sua maioria considera que os títulos foram dados por causa de apariçóes ou de imagens encontradas ou por certa circunstância comprobatória da intervenção milagrosa de Maria.

Mas, se por um lado, a multiplicação de invocações marianas facilitou a penetração do catolicismo nas camadas populares brasileiras, por outro lado criou uma ideia de multiplicidade de personalidades na mesma pessoa, a saber, a Virgem Maria, e facilitou a ocorrência de um sincretismo, como o demonstrado por Sidney da Silva entre imigrantes bolivianos que sintetizam a Virgem e a divindade andina Pachamama em uma única persona: "uma vez que para os indígenas aimarás o termo virgem corresponde a divindade feminina, o que permitiu a identificação da Virgem Maria com a divindade andina Pachamama" (Barnadas, 1977, p. 45 apud Silva, 2003, p. 105).

Renata Menezes (2005, p. 26) ressalta que o culto aos santos é interessante como objeto de estudo por sua ambivalência: demarca fronteiras dentro do mundo cristáo e extrapola os limites do catolicismo indo de encontro a religiosidades ou espiritualidades difusas. De fato, a imagem da Virgem é 
um dos aspectos mais distintivos das duas vertentes do cristianismo, separando católicos e protestantes em dois blocos distintos, onde um a venera enquanto o outro procura por muitos modos dessacralizá-la. Há uma espécie de recusa do protestantismo em reconhecer em Maria um destaque perante todas as demais mulheres do mundo. Apesar da própria Bíblia a considerar "bendita entre as mulheres" (Lucas 1:42), em resultado contrário aos dogmas católicos da Maternidade Divina, da Virgindade Perpétua, da Imaculada Conceiçấo e da Assunçáo aos Céus, os protestantes criaram uma espécie de rejeição incondicional a Maria e a tudo que lhe diz respeito.

Por outro lado, a feminilidade e a maternidade de Maria a aproximam do indivíduo brasileiro comum, carente dos cuidados celestiais e muitas vezes seguidor de uma espiritualidade difusa, sincrética, que se apropria de características de diversas religióes. Assim, Maria, em suas diversas associaçóes aparece comumente nos lares, nas vestimentas e nos adereços de um brasileiro que pode se denominar católico ou mesmo sem religiâo.

Quanto às formas mais comuns de se dirigir a Maria: Virgem Maria ou Nossa Senhora, vemos que a primeira delas é mais teológica por estar diretamente vinculada ao dogma da Virgindade Perpétua instituído pelo Concílio de Nicéia em 325 d.C. Já a segunda designaçấo, demonstra um elo entre o fiel e o objeto da veneraçáa: a Senhora, através do emprego do pronome possessivo, diminuindo a distância entre os dois e criando uma relação de intimidade.

Devido a estas características interessantes é que a devoção a Nossa Senhora ou a Maria se torna digna de estudo e compreensão. E, dentre todas as invocaçóes da Virgem no Brasil, que passam de 200 (123 no livro de Megale e 260 no livro de Zanon ${ }^{6}$ ), cabe-nos aqui estudar em especial a iconografia e a devoção a Nossa Senhora dos Remédios, devoçáo presente no Brasil desde os tempos coloniais e que tem uma íntima relação com o processo abolicionista em nossas terras.

6 ZANON, Frei Darlei. Nossa Senhora de Todos os Nomes: orações e história de 260 títulos marianos. São Paulo: Paulus, 2011.

Debates do NER, Porto Alegre, ANo i 8, N. 32, P. 259-287, JUl./DeZ. 2017 


\section{NOSSA SENHORA DOS REMÉDIOS: HISTÓRIA E ICONOGRAFIA}

No estudo histórico do surgimento dos títulos marianos, Aducci (2003) não se refere a Nossa Senhora dos Remédios, foco deste trabalho, mas nota-se que após o século XI, que coincide com o momento histórico da Reconquista ${ }^{7}$ o número de invocações aumenta expressivamente. Curiosamente, as imagens mais antigas de que se tem conhecimento com a denominaçáo de "Nossa Senhora dos Remédios" datam do século XII e relacionam-se diretamente às batalhas travadas entre cristáos e mouros.

É dentro desta perspectiva da Reconquista que surge a Ordem da Santíssima Trindade, reconhecida pelo Papa Inocêncio III em 1199 com o propósito de libertar os cativos cristáos sob o domínio dos Mouros, com sede em Cerfroid, França. A Ordem dos Trinitários tem sua fundaçáo datada em 1193 e em 1230 institui Nossa Senhora dos Remédios como patronesse e protetora da Ordem (Stroobants, 1991, p. 13). Apesar disto, esta devoçáo só seja associada oficialmente a esta Ordem em 6 de novembro de 1620, na Bula Papal de Paulo V, que une o título de Nossa Senhora dos Remédios a Confraria da Santíssima Trindade, contribuindo para a difusão da devoção (Porres Alonso, 1985, p. 101).

O fundador da Ordem, São João da Mata teria tido sua primeira visão de Nossa Senhora dos Remédios em Valência, no ano de 1202, quando este orava, atormentado pela imposiçấo dos Mouros em dobrar a quantia exigida pela redenção dos cativos dos quais viera para comprar a liberdade. Durante a oração a Virgem lhe apareceu entregando uma bolsa de moedas para "remediar" a situação em que se encontrava (Porres Alonso, 1985, p. 113). Ainda se tem o relato de mais outras apariçóes, das quais destacamos

7 A Reconquista ou Reconquista Cristã: nomes pelos quais ficaram conhecidas as campanhas militares contra os exércitos mouros que ocuparam a quase totalidade do território da Península Ibérica. 
a intervenção sobrenatural na vitória de D. João da Áustria contra os mouros, em Lepanto, no ano de 1571 (Grimaldi-Hierholtz, 1994, p. 39).

As primeiras imagens de Nossa Senhora dos Remédios, datadas do século XII e XIII, se apresentam como esculturas em granito ou madeira, no estilo românico, sempre com a virgem sentada em um trono, trazendo ao colo, sobre seu joelho esquerdo o menino Jesus, também sentado (Figura 1). Uma característica destas imagens é a expressão madura no rosto do menino Jesus, contrastando com sua idade física, que aparenta ser a de uma criança de cerca de 2 a 5 anos de idade. $\mathrm{O}$ menino Jesus faz com a mão direita o gesto de benção latina, com o dedo indicador e mediano levantados, quase verticalmente, simbolizando a dupla natureza de Cristo, enquanto os demais se juntam na palma da mão, simbolizando a sua participação na trindade. Certas imagens apresentam ambos, mãe e filho, coroados. Também variam os objetos $^{8}$ que a Virgem segura em suas mãos. Em algumas vemos uma bolsa de dinheiro na máo direita, numa representaçáo da ajuda entregue a São João da Mata para resgate dos prisioneiros entre os muçulmanos. Em outras representaçóes dos séculos XII e XIII, a virgem apresenta em suas mãos um cetro, simbolizando a sua realeza. Já o menino Jesus é representado segurando ora um cetro, ora um globo terrestre e ora um exemplar da lei de Moisés.

A partir do século XIV até o século XV, passamos a encontrar imagens no estilo gótico (Figura 2). A virgem ainda é representada sentada em um trono com o menino ao colo, mas pode-se observar uma delicadeza maior nos traços e no caimento das vestimentas. A austeridade do estilo românico é substituída por uma leveza de traços nos rostos da Virgem e do menino Jesus, que ainda apresenta uma expressão mais madura que a esperada para a idade representada. A postura dos personagens ainda é rígida, com a Virgem segurando uma bolsa de moedas, podendo estar coroada ou não. Apesar

8 Estes "objetos" que acompanham as imagens de Maria são representativos dos atributos de cada denominação mariana, diretamente relacionados aos seus respectivos relatos hagiográficos.

Debates do NER, Porto Alegre, ANo i 8, N. 32, P. 259-287, JUl./Dez. 20 I 7 
da ausência da coroa em algumas imagens, a ideia de realeza continua a se expressar pela existência do tono onde se assenta. Mais uma vez é digna de nota a presença da bolsa de moedas sendo ofertada por Maria para resgate de escravos. Podemos perceber através da permanência deste detalhe nas imagens que existe até o século XV uma estreita ligação da devoção com a história de São João da Mata e da Ordem da Santíssima Trindade.

Já no século XVI, começamos a encontrar apenas imagens com a Virgem de pé, com o menino ao braço, ora ao lado esquerdo, ora ao lado direito (Figura 3). A bolsa de moedas torna-se facultativa, podendo ser substituída por um cetro ou pelo escapulário 9 . O Renascimento reflete-se na feitura de imagens bem mais suaves, com rostos delicados e feiçóes serenas. As imagens deste período em diante mostram-se muito expressivas, gerando empatia e uma alta carga emocional no observador. Observa-se muitas vezes a presença de vidro nos olhos como forma de conferir mais vivacidade aos mesmos, cabelos humanos e de vestimentas de tecido em algumas delas. Essas características visam assemelhar a imagem aos humanos, mostrando seu papel de intermediária na comunicação entre os homens e Deus.

Do século XVI ao século XX encontramos basicamente três estilos de representaçôes de Nossa Senhora dos Remédios. Um dos tipos faz alusão diretamente a Ordem dos Trinitários, com a Virgem ora trajando o hábito da Ordem, ora vestindo-se com as cores da Ordem, mas sempre trazendo o menino Jesus em uma das máos enquanto a outra segura uma bolsa de moedas (Figura 4). Os outros tipos encontrados apresentam Maria segurando um ramo de vegetal ou um tipo de vaso ou apenas com a máo estendida à frente (Figuras 5 e 6 ).

Observando as imagens de Nossa Senhora dos Remédios do século XII ao século XX, podemos perceber alguns atributos que se mantêm presentes em quase todas independentemente da época da escultura ou do local onde

9 Na visão que Felix de Valois teve de Nossa Senhora dos Remédios, esta lhe entregou um escapulário, assim, tanto a imagem com a bolsa de moedas como a que segura o escapulário remetem ao mito das apariçóes marianas aos Trinitários.

Debates do NER, Porto Alegre, Ano i 8, N. 32, P. 259-287, JUl./Dez. 20 I 7 
foi produzida. Estes são a presença das cores vermelho e azul nas vestimentas da Virgem e do menino Jesus em um de seus braços. Quanto a distribuição geográfica da devoção a Nossa Senhora dos Remédios, vê-se que é possível traçar um caminho começando na França (século XII), passando pelas cidades da fronteira com a Espanha (século XIII), interior da Espanha e chegando a Portugal (século XIII), onde os Trinitários chegaram a ter 11 estabelecimentos (conventos, hospitais e colégios) e de onde lideraram a soltura de mais de 900.000 cristãos escravizados pelos mouros até o século $\mathrm{XIX}^{10}$. Alguns fatos, porém, chegaram a abalar a execuçâo da missão dos trinitários em terras portuguesas. Em meados do século XV, D. Afonso V instituiu um órgão estatal que seria responsável pela redençáo dos cativos, $\mathrm{o}$ Tribunal dos Cativos, sendo este o único autorizado para recolher donativos para este fim. A Ordem da Santíssima Trindade fica, portanto, proibida de exercer sua funçáo primordial, passando por um período a limitar suas atividades às de assistência social. Em 7 de julho de 1561, porém, um novo contrato restitui a Ordem a atividade redentora, submetendo-a, porém, a administraçáo da Coroa. Este contrato recebeu a aprovaçáo do Papa Pio IV em 1566. Após o século XVIII a ordem sofreu um rápido declínio ao ponto de náo mais existir em Portugal nos dias atuais.

Após expulsão das ordens de Portugal em 1834, os estabelecimentos trinitários passaram a ser administrados pelo governo e a lembrança da Ordem ou de sua relação com a devoção a Nossa Senhora dos Remédios foi aos poucos se apagando da memória do povo. Hoje, o desconhecimento da relação entre Nossa Senhora dos Remédios e a libertação dos cativos em Portugal entre é quase total, persistindo apenas dentro da academia científica. Apesar disso as igrejas de Portugal mantêm uma relação entre a devoçáo a Nossa Senhora dos Remédios e a prática de solidariedade, possuindo as paróquias que têm esta devoção como orago centros comunitários para atendimento social.

${ }^{10} \mathrm{O}$ último resgate geral de cativos efetuado pelos trinitários ocorreu em $1811 \mathrm{em}$ Argel. 


\section{NOSSA SENHORA DOS REMÉDIOS NO BRASIL}

O anuário católico 2008/2010 registra a existência de 34 paróquias dedicadas à Nossa Senhora dos Remédios no Brasil (Bahia, Pernambuco, Maranhão, Ceará, Amazonas, Minas Gerais, São Paulo, Rio de Janeiro e Paraná). Estas seguem a trilha da Ordem dos Trinitários no Brasil:

Os irmãos da Santíssima Trindade se empenhavam na difusão de suas devoções específicas e assim trouxeram para o Brasil o culto da Virgem dos Remédios, em honra da qual ergueram capelas em várias províncias do Nordeste (Maranhão, Pernambuco e Bahia) e nas regióes barrocas de Minas Gerais (Megale, 2008, p. 422).

Curiosamente, a primeira missa em ambiente fechado no Brasil foi realizada em uma Igreja de Nossa Senhora dos Remédios, em Arraial do Cabo, RJ. Esta igreja foi construída em 1506, junto ao marco da chegada de Américo Vespúcio a Arraial do Cabo, que ocorreu em 1503. É uma das mais antigas construçóes do Brasil, sendo a igreja original feita em pau-a-pique. Em 2003 a igreja passou por uma restauração. Interessante observar que a imagem que hoje está no altar mor da Igreja não apresenta as características esperadas ${ }^{11}$, pois Maria não segura o menino Jesus ao braço como as demais, mas em sua mão esquerda estendida está depositado um minúsculo menino Jesus como os de presépio. A vestimenta da imagem também não apresenta as cores usuais (vermelho e azul) sendo esta rosa, azul e branca. Maria traz na mão direita uma rosa. Sabe-se, porém, que esta não é a imagem original do século XVI.

Das capelas dedicadas à Nossa Senhora dos Remédios fundadas por membros da Ordem da Santíssima Trindade ou por seus adeptos entre os séculos XVI e XIX, apenas a localizada em Juerana, Bahia é ainda ligada a Ordem dos Trinitários. Esta Comunidade provavelmente tem seu início

${ }^{11}$ Esta imagem de Nossa Senhora dos Remédios destoa completamente dos dois padrões iconográficos encontrados na Europa e no Brasil, registrados neste trabalho. 
em 1581 com a vinda de um padre francês com Manuel da Nóbrega para a fundação da aldeia de Caravelas, onde erigiu pequena igreja. Hoje a igreja de Juerana tem São João da Mata como seu orago, celebrando-o com grandes festas anuais.

José Hertzer (1975) acredita que o primeiro local onde o culto a Nossa Senhora dos Remédios se estabeleceu tenha sido no Mosteiro de São Bento na Bahia, fundado em 1582, que foi o primeiro mosteiro a ser construído no país. Tendo conhecimento da incursão de um frade da Ordem da Santíssima Trindade na Bahia em 1581 e da existência até hoje de uma igreja trinitária em Juerana, torna-se mais importante o pequeno "santinho"12 impresso na Bahia, no século XIX com uma representação de Nossa Senhora dos Remédios muito difundida no século XVIII, de autoria de Augustín Sellent (Porres Alonso, 1985, p. 231-233). O desenho apresenta a Virgem vestida com o hábito Trinitário. Na parte inferior, vemos à esquerda quatro cativos em atitude suplicante: três de joelhos e um prostrado. $\mathrm{O}$ prostrado tem junto a si um estandarte inclinado encimado pela cruz trinitária. A direita tem-se ajoelhados os fundadores da Ordem dos Trinitários: S. João da Mata, um pouco mais elevado do solo, toma com sua direita o escapulário que o entrega a Virgem e estende a esquerda em direção aos escravos, intercedendo por eles; S. Felix, em um nível inferior, tem as mãos cruzadas sobre o peito em atitude humilde de adoração e suplica. Porres Alonso (1985, p. 547) registra que esta imagem impressa teria a seguinte anotação: "NOSSA SENHORA DOS REMÉDIOS/Padroeira da Celestial Ordem 3. a da S.S. Trindade da Bahia". Na imagem lê-se também em francês: "N. D. DU REFUGE (sic)"; e em espanhol: "N. S. DEL (sic) REMEDIOS". A confraria de Nossa Senhora dos Remédios na Bahia que teria produzido esta imagem foi criada 26 de agosto de 1806.

Esta ilustração mais o fato da existência da igreja de Juerana são evidências da chegada de frades trinitários ao Brasil durante o período escravocrata,

12 Estampas de santos ou cenários piedosos que demarcam e celebram atos religiosos de natureza sacramental e festiva entre católicos praticantes (Moura, 2006).

Debates do NER, Porto Alegre, ANo i 8, N. 32, P. 259-287, JUl./DeZ. 20 I 7 
podendo, portanto, ter exercido influência na formaçáo de frentes antiescravistas. Partindo da Bahia, os missionários trinitários teriam chegado às principais cidades brasileiras no século XVIII, passando pelos estados de Minas Gerais, São Paulo e Rio de Janeiro.

Alguns aspectos merecem destaque nesta distribuição geográfica como o fato destas localidades terem importância como regiôes de colonizaçáo com alta presença de escravos negros. Dentre estas, destaca-se a Capela em Jacareí, SP, construída por Bartolomeu Fernandes de Faria, fazendeiro e proprietário de muitos escravos e, a capela na Praça João Mendes, cidade de São Paulo, construída em 1720, e que abrigou escravos fugidos, uma escola para filhos do ventre livre e o primeiro jornal abolicionista de Sáo Paulo $^{13}$. É digna de mençáo a existência em 1788 de uma irmandade de Nossa Senhora dos Remédios na capela de Santa Efigênia, no Rio de Janeiro, formada por negros da Costa da Mina, que visava amparar os negros velhos, que porventura fossem deixados à mingua por seus senhores, providenciando medicamentos, vestimentas e um enterro digno ${ }^{14}$.

Dentre as demais igrejas e capelas dedicadas à Nossa Senhora dos Remédios no Brasil, destaco aqui as imagens encontradas nas Igrejas em Paraty, RJ e em Fernando de Noronha, PE. Observamos nas duas imagens características bem semelhantes quanto às cores das vestimentas, conservando a Virgem ainda as cores azul e vermelho (cores da cruz trinitária), e o menino Jesus apoiado sobre o braço esquerdo, enquanto que estende o braço direito segurando ou uma taça ou uma flor. Sustentando a Virgem vê-se algumas cabeças aladas de anjos. A mão direita de Maria encontra-se estendida como que a segurar algo.

${ }^{13}$ Para mais detalhes, ver: Ribeiro, Lidice M. P. A Libertação de Cativos sob o Manto de Nossa Senhora dos Remédios. Curitiba: Editora Prismas, 2016.

${ }^{14}$ Compromisso da Irmandade de Nossa Senhora dos Remédios - Estatuto da Irmandade de Nossa Senhora dos Remédios situada na Capela de Santa Efigênia, no ano de 1788, com 24 capítulos - documento depositado no Arquivo Histórico Ultramarino de Lisboa (AHU/CU, Códice 1300). 
Paraty, era na época da colonizaçáo brasileira um dos principais portos do litoral sul, além de ser o ponto inicial para o caminho em direção a Minas Gerais. A primeira igreja de Nossa Senhora dos Remédios em Paraty foi edificada em 1646 em um terreno doado, sob a condição de que a capela ali construída fosse dedicada à invocação de Nossa Senhora dos Remédios. A imagem ali exposta no altar mor é considerada milagrosa (Megale, 2008, p. 422). A imagem atual é tida como tendo sido adquirida na Espanha no século XIX.

A única igreja católica existente em Fernando de Noronha, é dedicada à Nossa Senhora dos Remédios e foi construída em 1737, logo depois da expulsão dos franceses da ilha. Consta que a primeira imagem de Nossa Senhora dos Remédios teria sido trazida por marinheiros que naufragaram na ilha, tendo a devoçáo vindo através da confiança na proteção da Virgem obtida na batalha de Loreto. Sabe-se que na segunda expedição enviada por Portugal ao Brasil, saída do Tejo em 1503, o navio Capitânea da esquadra comandada por Gonçalo Coelho, da qual também fazia parte Américo Vespúcio veio a naufragar no arquipélago de Fernando de Noronha. Do arquipélago, Gonçalo Coelho rumou para o sul, costeando a terra até a latitude de 18 graus, entrando no porto de Caravelas onde fundaria uma feitoria com 24 homens antes de retornar a Lisboa. Vale a pena lembrar que Juerana, na Bahia, onde desde o século XVI encontra-se uma igreja trinitária é um distrito da cidade de Caravelas.

A Ilha, porém, foi entregue por doação pelo Rei D. Manuel I a Fernan de Loronha, fidalgo financiador da expedição que a descobrira. Torna-se assim a primeira Capitania Hereditária do Brasil, mas por falta de interesse de seu donatário, permaneceu abandonada. Entre 1635 e 1654, a ilha foi ocupada pelos holandeses, que ergueram a Fortaleza dos Remédios. Após Portugal expulsar os holandeses da ilha, esta ficou novamente abandonada até que em 1736 foi invadida pelos franceses, que the ampliaram as construçôes. Em 1737, os Portugueses expulsam os franceses e erguem a Vila dos Remédios, a Igreja de Nossa Senhora dos Remédios e o Presídio. Se esta devoçáo foi difundida na ilha através de um marinheiro náufrago ou se por 
algum devoto trinitário francês no período de ocupação ainda não se sabe. A Virgem dos Remédios é na ilha considerada uma protetora, além de ter o poder para curar doenças e males sociais e espirituais. A partir de 1768, passou a ser a padroeira da Ilha.

É importante ainda destacar a Igreja de Nossa Senhora dos Remédios construída na Praça João Mendes, São Paulo, em meados de 1720, demolida em 1942 e reconstruída em outro local em 1944. Esta igreja, na qual se reunia a confraria de mesmo nome teve grande participação nas açôes que colaboraram para a proclamação da abolição da escravatura no Brasil.

O arquiteto Carlos Faggin em uma pesquisa realizada em 1985 conseguiu identificar 3 imagens de Nossa Senhora dos Remédios nesta Igreja. Dentre elas, uma imagem depositada no então coro da igreja, da qual foi dito ser a que ocupou originalmente o altar mor da primeira igreja. Provavelmente se tratava da imagem original do século XVII, hoje desaparecida. Na foto tirada por Faggin (1986, p. 63), pode se ver que a Virgem está vestida com um manto da Ordem da Santíssima Trindade com a cruz trinitária ao peito ${ }^{15}$. No braço esquerdo traz o menino Jesus enquanto que estende o braço direito à frente. As duas outras imagens que se encontram no templo atual, apresentam entre si características semelhantes. A imagem que se encontra no altar principal apresenta a Virgem com um manto azul e vermelho estrelado, e cruz no peito. Com os cabelos soltos, sem véu, apoia o menino Jesus sobre o braço esquerdo enquanto segura seus pés com a mão direita. O menino Jesus, por sua vez, aparentando ter cerca de cinco anos, usa uma túnica rosa e dourado e estende a mão direita em sinal de benção. Tanto a Virgem como o menino são coroados. A imagem utilizada nas procissóes de comemoraçáo do dia de Nossa Senhora dos Remédios, apesar de ser de confecção mais rústica, possui as mesmas características exceto pela ausência de coroa no menino Jesus.

${ }^{15}$ A mesma cruz trinitária pode ser vista ainda no brasão mariano oriundo da Igreja de Nossa Senhora dos Remédios original, que se encontra preservado no Museu de Arte Sacra de São Paulo. 
É interessante observar que toda a obra redentora realizada pela Igreja de Nossa Senhora dos Remédios na cidade de São Paulo tem uma grande semelhança a obra realizada pelos frades trinitários em Portugal e França. Também nos salta à vista o fato que as duas imagens remanescentes e a fotografada por Faggin apresentarem características que remontam à origem da devoção trinitária.

$\mathrm{Na}$ cidade de Caxambu encontramos outra das primeiras capelas dedicadas à Nossa Senhora dos Remédios no Brasil, datada de $1748^{16}$. Outras fontes, porém, datam a capela em 1868. Não há muitos indícios que liguem a capela do século XVIII a Ordem da Santíssima Trindade. Não há também uma dataçáo certa da imagem que hoje é exposta no altar principal. Consta que a mesma voltou ao altar mor após a reforma de 1952. O que chama a atençáo é o fato da Virgem trajar-se de azul e rosa e segurar o menino Jesus no braço esquerdo enquanto que traz à máo direita um ramo de uma planta. Pelas características desta imagem, parece-me que a mesma remonta ao século XX e que por isso já traz em si uma reinterpretaçáo do simbolismo de Nossa Senhora dos Remédios, remetendo-a à cura de doenças (representada pela erva em suas máos) e não mais a soltura de cativos. Teria, portanto, havido uma substituiçáo de imagens, acompanhando a mudança do enfoque da devoção mariana. Hoje, tanto no Brasil como em Portugal, a devoçáo a Nossa Senhora dos Remédios é entendida como uma referência a resoluçáo de problemas ligados a saúde física.

Corroborando a hipótese da gradual substituição da ligação de Nossa Senhora dos Remédios a libertação de cativos para a cura de doenças e proteção, João do Rio (1908), referindo-se às oraçóes mais utilizadas no Rio de Janeiro, no início do século XX, referencia-se a de Nossa Senhora dos Remédios, usada pelas mães de recém-nascidos: "Acompanham-na a oração para a dentição e a de Nossa Senhora dos Remédios, logo depois de nascido".

${ }^{16}$ AMARAL, Leandro. Caxambu. Jornal da Orla. Santos, 2008. Disponível em: <http://www.jornaldaorla.com.br/noticias/9348-caxambu/>. Acesso em: 15 jan. 2014.

Debates do NER, Porto Alegre, ano i 8, N. 32, P. 259-287, Jul./Dez. 2017 


\section{NOSSA SENHORA DOS REMÉDIOS E NOSSA SENHORA DO LEITE: ASSIMILAÇÓES E SINCRETISMOS}

Uma curiosa diferença iconográfica é observada em algumas igrejas dedicadas a Nossa Senhora dos Remédios em Portugal e no Brasil. O fato foi observado em Lamego, Portugal, que tradicionalmente é considerado um local de peregrinação quase tão importante quanto Fátima, em uma pequena cidade também de Portugal, chamada Bobadela e no Brasil, na cidade de Piripiri, PI. As imagens de Nossa Senhora dos Remédios nestas três localidades em especial apresentam-se com as características de "Nossa Senhora do Leite".

A devoção à Nossa Senhora dos Remédios na cidade de Lamego tem seu início no século XIV. Frei Agostinho de Santa Maria afirma ignorar a origem da imagem venerada em Lamego, porém sugere que ela possa ter sido trazida de Roma, para o altar da capela construída em 1568 (Marrana, 2001, p. 28). Também dá a entender que possa ter existido uma imagem anterior que seria cultuada na capela de Santo Estevão, a primeira construída no local, no ano de 1361.

Marrana (2001, p. 29), porém, registra um inventário dos bens da capela realizado em 16 de agosto de 1741, onde teriam sidos arroladas 3 imagens de Nossa Senhora dos Remédios sendo uma delas descrita como: "outra imagem da mesma senhora pequenina, com uma coroa de prata, com caixa de lata que fez o ermitão". Marrana identifica as duas outras imagens que constam no inventário como sendo imagens de Nossa Senhora do Leite existentes na Igreja atual, ficando uma no altar mor e outra em cima de uma mesa em dias de festa e registra que, fazendo pesquisas nas salas superiores a sacristia, deu por encontrar a outra imagem: "Encontramos dentro de um oratório velho uma imagem que tinha na peanha a seguinte legenda a letras de ouro: Nossa Senhora dos Remédios" (Marrana, 2001, p. 30).

Marrana (2001, p. 30) datou esta imagem como sendo do século XIV e se surpreendeu pela mesma não possuir os traços de Nossa Senhora do Leite como as imagens veneradas hoje no santuário: "tem o menino Jesus 
nas mãos, a segurar uma pombinha e uma esfera". Conclui então que esta deveria ser a imagem mais antiga que seria venerada na capela de Santo Estevão e que as imagens de Nossa Senhora do Leite teriam sido trazidas posteriormente, no século XVI.

Fato é que no acervo do Inventário da Coleção de Registro de Santos, de Ernesto Soares (1955, p. 218), há a descrição de uma figura (03040) de Nossa Senhora que corresponde à mesma imagem de Nossa Senhora do Leite que hoje se encontra no altar mor (Figura 7):

Nossa Senhora do Remédios - Numa moldura tipografada. Nossa Senhora em corpo inteiro amamentando o Menino, ambos coroados. INS - Nossa Senhora dos Remédios - que se venera na sua Real Capela junto à Cidade de Lamego. - Tomada sob a real e imediata proteçâo de Sua Majestade El Rei D. Pedro V por alvará de 30 de novembro de 1858.

O mesmo é observado na Paróquia de Nossa Senhora dos Remédios na cidade de Bobadela, Portugal, onde a imagem de Nossa Senhora dos Remédios se apresenta com Maria a amamentar o menino Jesus, a semelhança da imagem em Lamego (Figura 8).

No Brasil, a devoção a Nossa Senhora dos Remédios sob a iconografia de Nossa Senhora do Leite pode ser observada no Piauí, na cidade de Piripiri (Figura 9). A fundação desta cidade remonta ao período entre 1840-1844, quando o Padre Domingos de Freitas ${ }^{17}$ e Silva, vindo buscar refúgio após ter lutado pela independência do Piauí construiu uma casa e ao lado, uma capela dedicada à Nossa Senhora dos Remédios ${ }^{18}$. Consta que a imagem

${ }^{17} \mathrm{O}$ padre Domingos de Freitas e Silva é considerado o fundador da cidade. Em 1844, ele teria começado a cultivar terras que fariam parte do engenho Anajás. Posteriormente, o padre teria dividido as terras do engenho em lotes doando-os, dando origem à cidade de Piripiri.

${ }^{18}$ O padre Domingos de Freitas e Silva, filho de portugueses, estudou no seminário de São Luis, MA, cidade onde a Igreja de Nossa Senhora dos Remédios data de 1719, construída no período do bispado de Dom Frei José Delgarte, da Ordem da Santíssima Trindade e Redenção de Cativos (Bispo de Maranhão e Pará de 1716 a 1724).

Debates do NER, Porto Alegre, ANo i 8, N. 32, P. 259-287, JUl./Dez. 20 I 7 
original trazida no século XIX pelo padre Domingos para esta capela está no Convento Franciscano desde 1953. Esta imagem apresenta a Virgem segurando o menino Jesus nu, apoiado sobre o braço direito. Náo apresenta as características encontradas nas demais imagens de Portugal, França, Espanha e Brasil, como as vestimentas em vermelho e azul, cruz ao peito e a mão esquerda estendida. A Virgem representada nesta imagem possui as vestes nas cores verde, vermelho e dourado e não apresenta a mão estendida, mas ambas as mãos seguram o menino. Mesmo que esta imagem não tenha sido a originalmente entronizada no século XIX, é importante observar que a devoção original a Nossa Senhora dos Remédios em Piripiri não tenha sido a uma imagem de Nossa Senhora do Leite, como a que hoje se encontra no altar mor da Paróquia. É muito provável que a imagem, entronizada pelo Padre Domingos fosse relacionada a devoção original dos Trinitários, visto que estudou no Seminário de São Luis, MA, onde a devoçáo a Nossa Senhora dos Remédios chegou no século XVIII, trazida pelo Bispo Dom José Delgarte, frade da Ordem da Santíssima Trindade e Redenção dos Cativos. A imagem atual desembarcou em Parnaíba e foi trazida em procissão até Piripiri. O livro de tombo da Paróquia registra:

A imagem que orna o altar mor desta Matriz adquirida por iniciativa de uma pessoa piedosa auxiliada pelo povo, substituiu a antiga padroeira de vulto menor e muito imperfeita. Foi benta solenemente no Domingo de Pentecostes, 30 de maio de 1909. Freguesia de Nossa Senhora dos Remédios, $1^{\circ}$ de junho de 1909.

A troca da imagem teria se dado pela primeira ter dimensóes reduzidas e ser considerada imperfeita. Daí a vinda de uma imagem de grandes proporçóes e vinda do exterior, com influência, portanto da devoção já estabelecida em Lamego, Portugal.

Digno de nota é o fato de que a imagem de Nossa Senhora do Leite foi rapidamente aceita e entronizada com o título de Nossa Senhora dos Remédios, apesar da nova imagem apresentar Maria amamentando o menino 
e não apenas o segurando em suas mãos como a anterior. A fácil aceitação da troca da imagem demonstra que, mesmo que a devoção originalmente trazida pelo Padre Domingos possa ter tido ligaçóes com o mito trinitário, isto foi aos poucos se perdendo na devoção popular.

Moisés Espírito Santo (1988, p. 29) demonstrou em seu trabalho sobre as origens da religião portuguesa que o deslocamento da devoção gera novos topônimos. Para ele, a divindade que se cultua fora de sua localidade de origem já não é mais a mesma, mas sim cópias ou procuradoras da original. Para justificar sua afirmação, Espírito Santo utiliza-se do exemplo de Nossa Senhora da Conceição, que quando assume o nome de outra localidade que não o de sua origem (Valos), parece assumir uma outra identidade. O poder mágico atribuído ao espaço sagrado da primeira aparição (que impregna o topônimo) modifica a essência do nome apesar da invocação parecer a mesma.

Os topônimos dos cultos são só por si fonte de poder religioso, da "virtude" da senhora. O sagrado depende fundamentalmente do espaço sagrado. $\mathrm{O}$ cariz milagroso das senhoras reside no topônimo, exclusivamente no nome e no topônimo. Imagens iguais com o mesmo nome tem sorte diversa, conforme topônimos: a Senhora da Conceição de Vagos "é muito forte", a Senhora da Conceição de Carnaxide "já valeu muito e hoje vale pouco" [...] O poder vem-lhe do espaço onde mora, afirma-se ou decresce conforme as conjunturas, os modos de produção e certas tendências gregárias impossíveis de circunscrever (Espírito Santo, 1988, p. 30).

Cada Nossa Senhora seria, portanto, possuidora de um território, o que as histórias de imagens que se recusam a permanecer em local diferente do local de onde a aparição ocorreu parece corroborar. Assim, podemos perceber que a devoção em si, juntamente com a ideia de territorialidade contribui para assegurar uma identidade ao fiel, através de "uma forte coesão do grupo étnico e social” (Carvalhinhos, 2005, p. 132).

Segundo Câmara Cascudo (2002, p. 731), “o estado virginal confere poderes sobrenaturais. Certos remédios dobram de eficácia se servidos por mão de virgem". Talvez aí resida o segredo da transposição de significados 
atrelada a mudança iconográfica. A assimilação do novo significado de "remediar" uma situação difícil para dar remédio aos males humanos. Se o leite materno é o primeiro e mais forte medicamento natural, sendo leite virginal ${ }^{19}$, maior a sua eficácia sobrenatural.

\section{O TÍTULO “NOSSA SENHORA DOS REMÉDIOS” ONTEM E HOJE}

"Esquematicamente, Maria é o referente do qual derivam várias invocaçôes, na terminologia católica; numa primeira análise, podemos pensar que Maria se encontra num eixo sintagmático do discurso, e no eixo paradigmático estão todas as suas denominaçôes" (Carvalhinhos, 2005, p. 173).

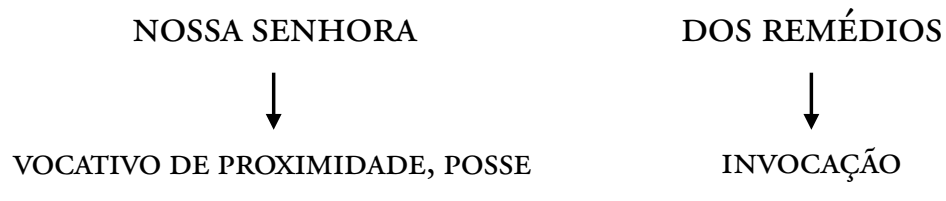

Em sua análise sobre as invocações marianas no território de Portugal, Carvalhinhos (2005, p. 179) destaca a elevada quantidade de invocaçóes que se referem ao que a Virgem oferece (em termos de proteçáo) ou cura. Dentre as invocaçóes que esta autora considera como sendo referentes a benefícios, onde uma situaçáo desejada seria alcançada ou um estado aflitivo seria afastado, encontra-se a Nossa Senhora dos Remédios O fiel entra "em conjunção com seu objeto de desejo (alívio, proteção, solução)" estabelecendo "uma relação com o destinatário [a senhora]" (Carvalhinhos,

${ }^{19}$ Ressalta-se que o dogma da virgindade perpétua de Maria foi proclamado em 649, pelo Concílio Ecumênico do Latrão, retomado pelo II Concílio de Constantinopla (553) e confirmado por outros dois Concílios Ecumênicos: o Lateranense IV (1215) e o Concílio de Lião (1274), e pelo texto da definição do dogma da assunção (1950), no qual a virgindade perpétua de Maria é adotada entre os motivos da sua elevação, em corpo e alma, à glória celeste. 
2005, p. 184). Em um levantamento em Portugal, Carvalhinhos (2005, p. 201) relaciona 39 locais de invocação de Nossa Senhora dos Remédios.

François Stroobants (1991) aproxima os significados das palavras remédio e redenção, e defende que São João da Mata, fundador da Ordem dos Trinitários e seus primeiros discípulos decidiram invocar a Virgem por um título especial relacionado às atividades de libertação dos cativos realizada pela ordem: Nossa Senhora do Resgate ou da Redenção. Propóe que tenha acontecido uma troca entre a palavra medieval redemium e a palavra remedium (em francês redeme e remede) ou mais provavelmente, devido ao fato de nos tempos medievais, particularmente nos séculos XII e XIII, remedium ter o significado de redenção, aquela palavra poderia substituir frequentemente a outra.

São Joáo Damasceno, referindo-se a Nossa Senhora dos Remédios, diz que é "a saúde perfeita das almas; porque esta Senhora não só se compadece dos nossos males e misérias temporais; mas muito mais das enfermidades das almas, procurando-nos sempre saúde delas. Tudo isso experimentam os devotos de Milagrosa Senhora" (Santa Maria, 1707, tomo 3, p. 227). O mesmo autor diz que o significado da palavra Remédios está nas cinco letras da palavra MARIA: M - Maria; A - advocata; R - remedia; I - imperat; A ou AE - Aeguis. Assim fecha a palavra Maria advocata remedia imperat aeguis que significa Maria, nossa advogada, alcança o remédio para os enfermos.

\section{CONSIDERAÇÓES FINAIS}

A iconografia de Nossa Senhora dos Remédios representa diretamente a relaçáo entre o fiel e sua devoção. Dessa forma, vemos que, coincidentemente com as referências das primeiras visagens desta invocação, surgem imagens com representação relacionada ao mito da aparição a Sáo Joấo da Mata. Com a expulsão da Ordem dos Trinitários em Portugal em 1834, juntamente com as demais ordens religiosas, a relaçáo entre a devoção a 
Nossa Senhora dos Remédios e a Ordem dos Trinitários se perde. Aos poucos, as paróquias que lá permanecem tendem a substituir a bolsa de moedas por outros objetos, como um ramo ou um cetro. A invocaçáo não desaparece, como Carvalhinhos pôde comprovar, mas perde sua conexão com a Ordem da Santíssima Trindade. Nos demais países onde a Ordem dos Trinitários se instala, porém, não ocorre esta mudança, sendo ainda observadas representaçóes de Nossa Senhora dos Remédios portando o manto trinitário e/ ou a bolsa de moedas.

No século XIX, com a extinção progressiva da escravidão africana, luta a que se dedicaram os Trinitários após o final das Cruzadas, a Ordem se reestrutura em função de remediar todos os problemas sociais que "escravizam" a humanidade, incluindo doenças, e a narco-dependência. Juntamente, há uma mudança progressiva do sentido e compreensão da devoção, deixando esta de ser ligada à libertação de cativos (redenção) para se tornar uma proporcionadora de saúde e bem-estar (remediar). Assim, do século XIX em diante, as representaçóes de Nossa Senhora dos Remédios, exceto as pertencentes a igrejas e conventos da Ordem Trinitária, passam a não mais apresentar a bolsa de moedas e sim a máo estendida a oferecer todo tipo de "remédio" aos homens.

Aos poucos a concepção de remédio e saúde passam a pontar para a vida, fazendo com que certas imagens de Nossa Senhora dos Remédios se apresentem amamentando o menino Jesus, como que a referendar o simbolismo do leite materno como elemento vital e conferidor de saúde aos seres humanos desde o seu nascimento. Assim as imagens de Nossa Senhora dos Remédios acabam por se tornar uma versão de Nossa Senhora do Leite. 
Figura 1

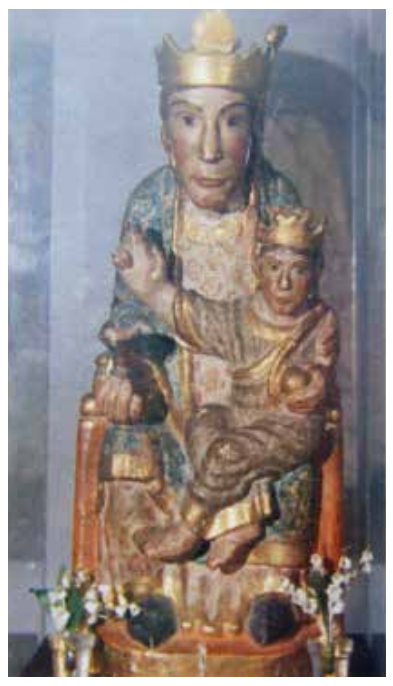

Figura 2

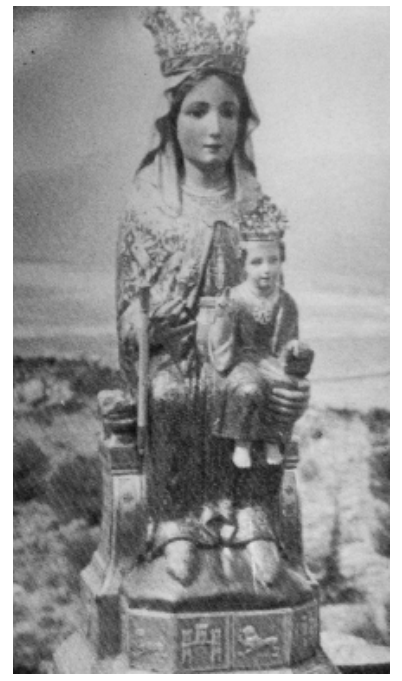

Figura 3

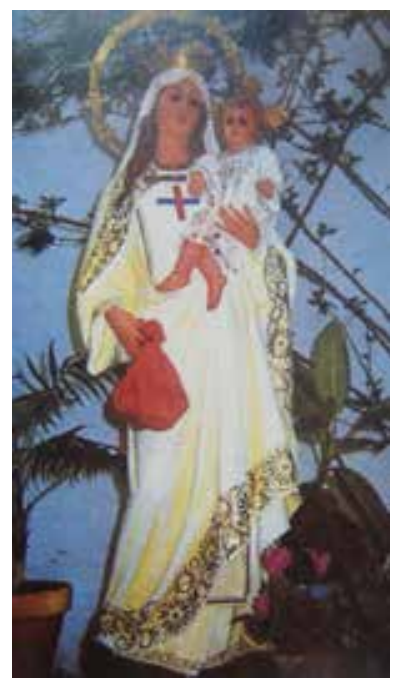

Figura 1 - Virgen del Remédio - Igreja Paroquial de Santa Coloma, Andorra - século XII. Fonte: Stroobants, 1991.

Figura 2 - Nossa Senhora dos Remédios - Colmenar Viejo, Madrid, Espanha - Ermida de Nossa Senhora dos Remédios - século XIV. Fonte: Porres Alonso, 1985.

Figura 3 - Nossa Senhora dos Remédios em Badajoz, Espanha - século XVI. Fonte: Stroobants, 1991. 
Figura 4

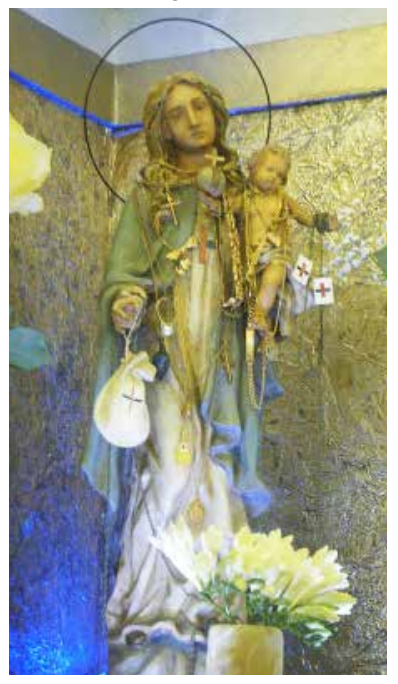

Figura 5

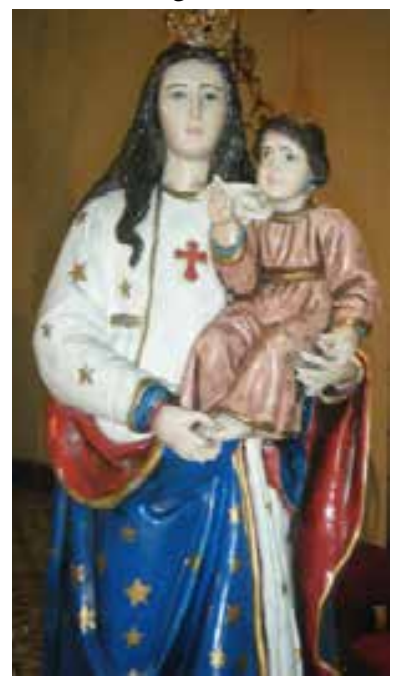

Figura 6

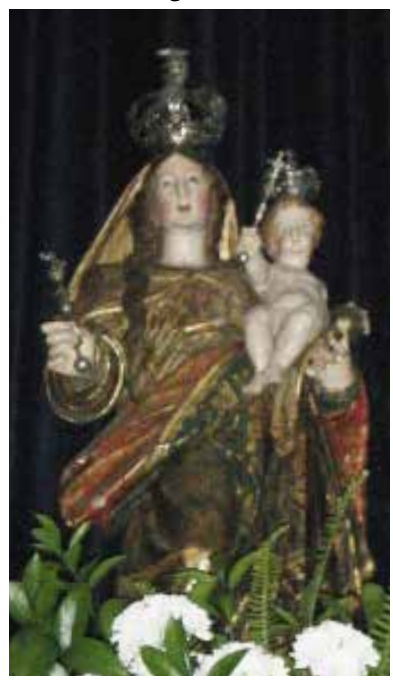

Figura 4 - Nossa Senhora dos Remédios - Mosteiro Trinitário em São Miguel Paulista, SP - Século XVIII. Fonte: Foto da autora.

Figura 5 - Nossa Senhora dos Remédios - Igreja de Nossa Senhora dos Remédios, Cambuci, São Paulo, SP - século XX. Fonte: Foto da autora.

Figura 6 - Nossa Senhora dos Remédios - Paróquia de Carcavelos, Portugal - século XVIII. Fonte: Foto da autora. 

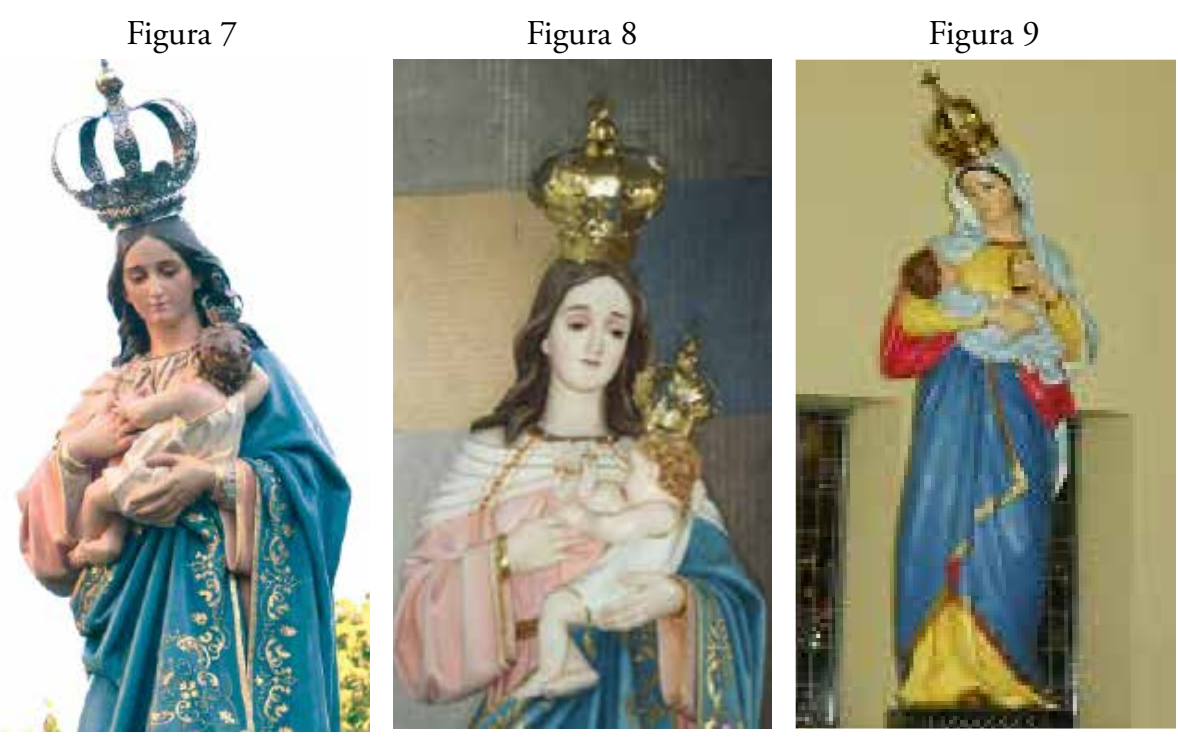

Figura 7 - Nossa Senhora dos Remédios - Santuário de Lamego, Portugal - Século XIX. Fonte: Foto da autora.

Figura 8 - Nossa Senhora dos Remédios - Paróquia de Nossa Senhora dos Remédios, Bobadela, Portugal - Século XX. Fonte: Foto da autora.

Figura 9 - Nossa Senhora dos Remédios - Paróquia de Nossa Senhora dos Remédios, Piripiri, PI - Século XX. Fonte: Site da Paróquia Nossa Senhora dos Remédios. Disponível em: <http://paroquiadosremedios.com/>. Acesso em: 29 jun. 2013 


\section{REFERÊNCIAS}

ADUCCI, Edésia. Maria e seus Títulos Gloriosos. São Paulo: Loyola, 2003. ANTONIAZZI, Alberto. O catolicismo no Brasil. In: LANDIM, Leilah (Org.). Sinais dos Tempos: Tradiçôes religiosas no Brasil. Rio de Janeiro: ISER, 1989. p. 13-36.

CAMARGO, Cândido Procópio F de. Católicos, Protestantes, Espiritas. Rio de Janeiro: Vozes, 1973.

CARVALHINHOS, Patrícia de Jesus. Hierotoponimia portuguesa. De Leite de Vasconcelos às atuais teorias onomásticas. Estudo de caso: as Nossas Senhoras. 2005. 231 f. Tese (Doutorado em Semiótica e Linguística Geral) Faculdade de Filosofia, Letras e Ciências Humanas, Universidade de São Paulo, São Paulo, 2005.

CASCUDO, Luis da Câmara. Dicionário do Folclore Brasileiro. São Paulo: Global, 2002.

CHIAVENATO, Júlio José. Religião: da origem a ideologia. Ribeirão Preto: Funpec Editora, 2002.

ESPÍRITO SANTO, Moisés. Origens orientais da religiāo popular portuguesa, seguido de um ensaio de toponimia antiga. Lisboa: Assirio e Alvim, 1988.

FAGGIN, Carlos Augusto Mattei. Notas sobre o paradeiro dos retábulos da antiga Igreja dos Remédios em São Paulo. Revista Sinopses, São Paulo, n. 9, p. 63, 1986.

GRIMALDI-HIERHOLTZ, Roseline. L'Ordre dês Trinitaires. France: Fayard, 1994.

HERTZER, José. A Confraria de Nossa Senhora dos Remédios 1722. São Paulo: [s. n.], 1975. 
MARRANA, Cônego José Antonio. História do Culto de Nossa Senhora dos Remédios em Lamego. Lamego: Tipografia Voz de Lamego, 2001.

MEGALE, Nilza Botelho. Invocaçōes da Virgem Maria no Brasil. Rio de Janeiro: Vozes, 2008.

MENEZES, Renata de Castro. A benção de santo Antônio num convento carioca. Revista USP, São Paulo, n. 67, p. 24-35, 2005.

MOURA, Margarida Maria. Santos Santinhos: um fragmento da vida sacramental, festiva e familiar da alta classe média carioca 1910-1960. Cadernos CERU, São Paulo, n. 17, p. 145-175, 2006.

PORRES ALONSO, Bonifacio; ARIETA ORBE, Nicolas. Santa Maria del Remedio: historia de uma advocación mariana, com noticias de mil imágenes y santuários y dosientas ochenta y nueve ilustraciones. Cordoba: Editora Secretariado Trinitario, 1985.

RIO, João do. A alma encantadora das ruas. Domínio Público, 1908. Disponível em: <http://www.dominiopublico.gov.br/download/texto/bi000183.pdf>. Acesso em: 29 jun. 2013.

ROLIM, Francisco Cartaxo. Condicionamentos Socais do Catolicismo Popular. Revista Eclesiástica Brasileira, Petrópolis, v. 36, n. 141, p. 142-170, 1976.

SANTA MARIA, Frei Agostinho de. Santuário Mariano. Lisboa: Officinas de Antonio Peroso Cabrão, 1707-1723. 10 v.

SCHMITT, Jean-Claude. O corpo das imagens: Ensaio sobre a cultura visual na Idade Média. Bauru, SP: EDUSC, 2007.

SILVA, Antonio da. Virgem/Mãe/Terra: festas e tradições bolivianas na metrópole. São Paulo: Hucitec; Fapesp, 2003. 
SOARES, Ernesto (Org.). Inventário da Colecção de Registos de Santos. Lisboa: Biblioteca Nacional, 1955. Disponível em: <http://purl.pt/700>. Acesso em: 29 jun. 2013.

STROOBANTS, François. Notre-Dame du Remède ou du Rachat. Marseille: Imprimerie Montgrand, 1991.

Recebido em: 30/03/17 Aprovado em: 20/05/17 

ENTREVISTA 

ENTREVISTA COM JEANNE FAVRET-SAADA REALIZADA POR CYRIL ISNART PARA O JOURNAL DES ANTHROPOLOGUES DURANTE O COLÓQUIO SOBRE A EMPATIA NA ANTROPOLOGIA, AIX-EN-PROVENCE, 2007

\author{
Jeanne Favret-Saada ${ }^{l}$ \\ Cyril Isnart ${ }^{2}$
}

\title{
QUESTÓES DE MÉTODO
}

1) Qual era a sua posição metodológica durante sua pesquisa no Magreb, antes de você se dedicar à questão da feitiçaria do Bocage?

Comecei a ir a campo após a independência da Argélia (outono de 1962), mas já fazia três anos que eu tinha ido viver neste país que entáo estava em guerra. Meu conhecimento sobre a etnologia era apenas teórico, já que, até então, eu somente havia dado aulas na universidade. Além dos grandes autores franceses (Mauss, Lévi-Strauss...) e a etnologia colonial do Magreb, eu havia lido muito da antropologia anglo-americana, sob a orientação informal de Ernest Gellner. Minha "posição metodológica" teria sido totalmente clássica se a situação assim o fosse, mas a etnologia não tinha nenhum método para estudar um país em plena revolução. Durante dois anos, pesquisei o quanto pude em condiçóes inacreditáveis para um pesquisador. Era impossível fazer projetos e até mesmo residir por muito tempo onde quer fosse: às vezes, era preciso partir depois de três dias. Mas eu estava todo o tempo com camponeses e tinha um conhecimento diferenciado e historicizado das regióes. Gellner era o único etnólogo no mundo que acreditava que eu poderia fazer "ciência" com minhas anotaçóes sobre

1 Coordenadora de Pesquisas na École Pratique des Hautes Études (EPHE). Contato: favsa@club-internet.fr

2 Institut d'Ethnologie Méditerranéenne, Européenne et Comparative (IDEMEC), Université de Provence. Contato: isnartc@gmail.com 
esses episódios descontínuos e, sem sua confiança, eu não teria ousado publicar uma linha sequer.

2) O que você entende por "um conhecimento diferenciado e historicizado"? Você quer dizer que o conhecimento teórico vindo dos livros é diferente do conhecimento oriundo da prática de campo? Isso implica que o conhecimento livresco e erudito é, entretanto, necessário para o estabelecimento de um conhecimento em geral?

Sim, "o conhecimento livresco e erudito" é necessário! Meus antecessores do período colonial na Argélia tinham, com certeza, um viés ideológico por vezes enorme (suas distinções sobre as estruturas políticas entre Berbéres e Árabes, ou nômades e sedentários), mas eles haviam ensinado algo que poderia ao menos me servir como ponto de partida. Descobri no campo a relatividade das suas distinçôes e passei então a criticá-los. Entretanto, é verdade que essas pessoas que viveram o período colonial (oficiais, juízes, administradores) viram muitas coisas, mesmo se a partir de suas posiçôes sociológicas e políticas: teria sido estúpido jogar no lixo todos esses trabalhos sob o pretexto de que seus autores não tinham nascido em um bom momento!

3) A antropologia francesa da Europa, que por um tempo reivindicou pertencimento a Claude Lévi-Strauss, encarregou-se, à sua maneira, da herança dos folcloristas, nela aplicando um tratamento muito objetivante por meio de um uso comparativo dos dados brutos, e dando à mesma o status de fonte para tratar a longa duração da cultura. Como você se posiciona em relação a esta filiação?

Os autores demonstram de forma convincente a existência de redes de relaçóes entre significantes culturais aparentemente heteróclitos e a continuidade dessas redes após o colapso da "sociedade de costumes". Mas apesar de eu admirar sua incansável engenhosidade, suas análises não satisfazem minha curiosidade, e parece-me que, a priori, eles têm como base filósofos com os quais não compartilho nada. Veja a noção de sociedade "de costume": eles asseguram que ela se perpetuou durante cinco a nove séculos, mas, tal como a constituem, parece que a mesma não foi algo criado; ou foi, mas 
por um big bang análogo à improvável passagem lévi-straussiana da natureza à cultura. Em suma, tais autores testemunham uma indiferença massiva à variação histórica: sua cultura "de costume" é um estado perpétuo, um arranjo de "representaçôes" tão genial que os conflitos, se existem, vêm de outro lugar. Mas de onde? Suas análises parecem desconectar o registro da representação mental de tudo o que faz com que os humanos vivam e morram: os desacordos, as paixóes e os interesses, as práticas, as variaçóes, os acasos...

Tomemos por exemplo o livro tão perspicaz de Claudine Fabre-Vassas (1993), La Bête singulière: les juifs, les chrétiens et le cochon, e compare-o com Le Christianisme et ses juifs: 1800-2000, que escrevi com Josée Contreras (2004). Nosso livro é considerado estranho à antropologia (ver o silêncio das revistas especializadas a seu respeito), mas mesmo assim podemos refletir sobre ele.

Claudine Fabre-Vassas descreveu o antissemitismo cristão como representacional, verbal ou ritual. Ora, nós mostramos que ele sempre foi articulado com base em políticas (é claro, culturais de parte em parte, mas que devem ser descritas em suas variedades e suas variaçóes) e práticas entre as quais muitas não levam em conta o ritual (um progrom, é simbólico, mas pode-se também considerá-lo como um acontecimento histórico). A propósito das polêmicas sobre a Paixão de Oberammergau na Baviera, mostramos em quais conflitos são tomados os termos "tradição" ou "ritual": conflitos nas igrejas, conflitos históricos (o nazismo e suas consequências), conflitos políticos nacionais e internacionais, conflitos entre os grupos intelectuais os militantes, conflitos nas ciências sociais... Josée Contreras e eu não explicamos nem mesmo descrevemos o fato "antissemita" cristão em sua totalidade, mas nós nos perguntamos seriamente o que faltava a uma antropologia como a de Claudine Fabre-Vassas. 


\section{A RELAÇÃO COM OUTRO}

4) Por quais razóes o lugar entre etnógrafo e "nativo" jamais foi mostrado na literatura científica como um complexo de afetação recíproca, mas sim como uma relação de objetificação no campo?

Porque a antropologia, mesmo em suas tentativas mais humanistas, sempre manteve uma pressuposição de assimetria entre o etnógrafo e seu objeto. No tempo das colônias, esse objeto era inferior. Na sequência, esse paternalismo foi substituído por uma epistemologia da distância, que pretendia proteger o pesquisador contra a afetação por outrem. Em suma, facilitado por uma filosofia dualista que afirmava ad nauseam o primado da representação.

5) Pode-se dizer então que "a invenção das representaçôes" (vinda, em parte, dos durkheimianos) é um dispositivo cientifico - e ideológico? - que reproduz, apagando os afetos do campo, a objetivação, a distância, a fábrica da alteridade, a grande divisão? Esse parece ser o caso das "representaçôes" observadas pelos psicólogos sociais que dispóe de um regime de cientificidade fundado sobre o procedimento experimental.

O próprio Durkheim inscreve-se em uma tradição filosófica dualista que postula uma hierarquia entre a razão e o afeto. Quando esse dualismo transfere-se para as relaçóes entre o etnógrafo e o "outro", este tomba automaticamente do lado do afeto, da não razão etc.

6) Mas como a etnógrafa da feitiçaria fez para se desprender de suas armadilhas, já que, para qualquer etnólogo herdeiro de ferramentas coloniais, independentemente do que ele diga sobre isso, a nuance é sutil entre a distinção, no sentido bourdiano, e a diferenciação de seu próprio saber em relação ao saber dos outros? Este é somente um caso de precaução oratória?

Para se desprender dessas armadilhas, só existe um meio, uma posição epistemológica, sobretudo: ter em conta que, independentemente do que sabemos (ou cremos saber), é justamente devido ao fato de ignorarmos algo 
de essencial a propósito do outro que partimos para o campo. E o que de essencial? É, justamente, impossível sabê-lo de antemão. (Isso não impede de apresentar um projeto de pesquisa em seu laboratório, sob a condição de crer nele o mínimo possível).

Uma anedota. Em uma passagem por Paris (eu vivia então na Argélia sem ter feito o campo), eu tinha sido convidada a encontrar Margaret Mead. Com a garganta apertada de timidez, fui a um saláo do Sétimo Distrito. A ilustre senhora me bombardeou com perguntas sobre as observações dos judeus da Tunísia, grupo do qual sou proveniente. Ela havia construído seu questionário cruzando seus conhecimentos gerais sobre o judaísmo com os trabalhos de uma etnóloga israelense. Uma interlocução mínima comigo ou dois minutos de reflexão sobre o fato de que sua informante, suposta professora na universidade, falava inglês e tinha sido convidada para esse saláo parisiense, deveria ter feito com que ela suspeitasse de que a nativa serviço tinha deixado sua gruta de selvagem ou seu gueto há muito tempo, e seus ascendentes antes dela. (E também: de que sozinhos, entre os judeus da Tunísia, os "pobres" tinham imigrado para Israel e conservado uma vívida ligação com sua religião.) Em suma, fui incapaz de responder à célebre etnóloga, exasperada pelo encontro com uma informante recalcitrante.

Logo a seguir, quando comecei a trabalhar, meu primeiro princípio foi: já que ignoramos quais são as perguntas corretas, comecemos por nos calar e por compreender o que eles falam entre si, quais são para eles as questóes pertinentes. Tinha em mente minhas leituras da etnologia colonial, mas eu me calava até sentir que poderia adentrar sem violência no jogo ordinário de suas preocupaçóes. A ideia era que, malgrado meu saber enciclopédico, eu ignorava por princípio o que seria importante conhecer.

7) Refletir sobre a empatia na antropologia é, para a maioria dos etnólogos, exercer um tipo de retorno à experiência etnográfica, para compreender como as relaçôes estão entrelaçadas; é tomar a relação com outro como um instrumento de trabalho, deixando de lado às vezes as dimensóes de arrependimento, de 
remorsos, de ironia, de mentira, de afeição, de amizade ou de distância que implicam a distanciação da posiçāo do etnógrafo.

Várias observaçóes. Primeiramente, "a empatia”, em qualquer sentido que a tomemos, seria somente uma afetação recíproca e não a relação entre duas ilhas separadas por um mar. Em segundo lugar, a dimensão do afeto das relaçôes entre essas duas entidades é permanente na etnologia: é claro que a confrontação etnológica não é a reflexão sobre anotaçôes ou a escrita de um livro, mas ninguém, jamais, onde quer que seja, poderia ser desafetado. Por fim, sua lista de afetos ressentidos para o pesquisador é estranhamente limitada: onde estão a cólera, a raiva, o medo, a humilhaçẫo, o desespero?

8) $\mathrm{Na}$ "Retomada" de Corps pour corps, você descreveu suas primeiras impressóes etnográficas no Bocage, o que poderíamos chamar de uma entrada em campo, como uma sequência de estabelecimentos de contato decepcionantes com pessoas ilustres que repulsavam a ideia da existência de feitiçaria, e como uma observação etnográfica "flutuante", deixando-se "afundar nos hábitos nativos". Por que essa maneira de entrar em campo pareceu eficaz para sua abordagem e seu objeto de pesquisa?

Em um primeiro momento, as propostas dos considerados ilustres e dos eruditos locais do Bocage me decepcionaram, mas depois me exasperaram. Dois meses mais tarde, reli seus discursos na imprensa e na psiquiatria sobre a feitiçaria e eles passaram a me interessar intensamente, pois demonstravam a existência de um discurso "nacional" sobre a feitiçaria, de uma ideologia racionalista oficial que condenava os enfeitiçados e seus desenfeitiçadores. Reencontrei assim o "global" no próprio coração do "local", com o professor, o médico, o pároco, certos camponeses... Por outro lado, náo creio ter praticado uma "observaçáo etnográfica flutuante", pois a escolha é impossível: a noçáo de observação implica a ideia de uma vigilância atenta, de um exame sistemático. Digamos que vivi no local, sem questionar frontalmente sobre a feitiçaria, mas misturando-me aos bate-papos ordinários, que tratavam com frequência sobre a infelicidade, a doença, a morte, a repetição... Uma vez que eu pude produzir comentários pertinentes sobre essas situaçóes e entáo 
participar das conversas, ousei prudentes incursóes no que me parecia ser o campo da feitiçaria. Uma família camponesa me contou então, com uma grande emoção, uma história ocorrida com seus antigos vizinhos. $\mathrm{O}$ encontro, em seguida, com pessoas capazes de me dizer "eu, eu fui enfeitiçada" foi o fruto da minha determinação, dessa aprendizagem, mas também do acaso.

\section{COMO FALAR DOS OUTROS}

9) Você explica em "Ser afetado" que a empatia não qualifica justamente sua abordagem etnográfica, mas somente porque o conceito implica uma distanciação durante a pesquisa?

O emprego desse termo ("empatia") deveria ser abandonado na antropologia porque ele tem duas significaçôes contraditórias. Quer-se falar de uma comunicação imediata por fusão afetiva ou de um deslocamento mental, imaginado, de seu próprio local àquele do outro? Sem contar uma boa dúzia de outras noçóes (a simpatia pelo outro, etc.) que as obras recentes sobre "a empatia" se dedicaram a examinar. Do ponto de vista conceitual, "empatia" é o mesmo caso que "antissemitismo": um termo polissêmico a partir do qual se gostaria de fazer um termo analítico porque não se pode evitar empregá-lo. Mas não, é preciso se sujeitar a especificar o que se tem em mente.

10) Este é um problema das ciências sociais: a sobreposição da língua natural e da lingua que se considera que deve dar conta disso. Como você negociou essa sobreposição em seus próprios trabalhos?

Sim, este é um problema geral totalmente irresolúvel, mas em cada um de nossos trabalhos devemos propor uma solução particular. Não creio que seja necessário construir uma língua técnica, pois isso seria esquecer que os livros de etnologia não são destinados somente aos profissionais. Precisamos de um vocabulário específico, por exemplo, para descrever as relaçôes de

3 Cadernos de Campo, São Paulo, ano 14, n. 13, p. 155-161, 2005. Traduzido de FavretSaada (1990). (N.T.) 
parentesco, e de conceitos gerais para designar o objeto de nosso trabalho. Mas a maior parte desses conceitos são apenas termos polissêmicos: como dizia Sperber, eles amalgamam várias significaçôes dentre as quais há um vago ar de família, se bem que nossos debates teóricos são desesperadamente confusos. O único método para evitar isso: perguntar-se, a cada ocorrência de tal termo em um texto, o que ele não designa; quando ele não dá conta (veja "observação participante"), é que não se trata de um conceito. É preciso então questionar o debate teórico em questão: quem deu qual conteúdo a esse suposto conceito? Por quê? Em suma, fazer a lista de suas significaçóes, isto é, substituir essa palavra, que não é um conceito, por outras, inclusive por perífrases.

Tivemos que afrontar esse problema em Le Christianisme et ses juifs, com a palavra "antissemita": impossível utilizá-la como um termo analítico, mesmo se ela é recebida como tal nas ciências sociais. Salvo que cada ator tem sua pequena ideia sobre a questão de saber quem ou o que é "antissemita": há um acordo geral sobre Hitler e o nazismo, mas e para as igrejas cristãs? O leitor é então projetado nas grandes batalhas ideológicas que expóem também, como se não o soubessem, os historiadores, sociólogos e etnólogos. Escolhemos tratar "antissemita" como um termo polêmico da linguagem nativa e então fazer dele uma citaçáo, escrevê-lo entre aspas - nos impondo assim qualificar com precisão as situaçóes que descrevíamos. Da mesma forma, em Comment produire une crise mondiale avec douze petits dessins, especifiquei de início em qual sentido eu empregava os termos situando os atores da crise. E para a feitiçaria, identifiquei um discurso oficial público (pelo qual Lévi-Strauss se deixou levar sem refletir, um dia, quando ele prefaciava um trabalho sobre a feitiçaria em Berry) distinto daquilo que um etnólogo responsável deveria pensar.

11) Como essa sobreposição manifesta-se em outro campo que você explorou, a psicanálise?

Freud e os múltiplos grupos de psicanálise dedicaram-se a forjar conceitos teóricos que fazem um recorte na língua natural, a ponto de que não se pode 
tomar conhecimento da psicanálise sem a ajuda de dicionários especializados. Infelizmente, esse distanciamento do falar ordinário vem da pretensão de fazer com que a psicanálise passe por uma "ciência" nova: Freud assim o quis sob o modelo da fisiologia, Lacan sob o de uma linguística, cuja "teoria" imitaria os processos inconscientes.

12) Mas geralmente, quais foram os aportes dos dois tipos de "escuta" do outro - e de si - em seu método de exploração do real?

Não gosto de falar de escuta, isso situa os protagonistas de uma psicanálise ou do campo etnográfico de forma exageradamente assimétrica. Valeria mais falar de "presença em", de "atenção flutuante": o terapeuta deixa flutuar seu pequeno eu para que o paciente possa manipulá-lo e modelá-lo conforme sua ideia; o etnólogo deixa flutuar suas referências e abandona ao nativo o cuidado de designar o lugar que ele deve ocupar - um lugar desconhecido para o pesquisador, em um sistema de lugares que é precisamente o objeto da investigação. Mas essa situação é mais banal do que as posturas vantajosas do analista e do etnólogo permitem que se suponha: acontece o mesmo quando se aceita um deslocamento de si sem nenhum a priori sobre si mesmo, um transporte de si - tanto na natureza quanto na relaçáo amorosa.

13) A antropologia tem por objetivo um tipo de hermenêutica das culturas? Em outras palavras, trata-se de uma visão ingênua dos especialistas da antropologia cultural como C. Geertz que crê que é possivel uma "leitura por cima dos ombros do outro" de suas representaçóes culturais e de seu sistema simbólico ao se fundir elementos da observação, sejam eles explícitos ou implícitos?

A metáfora de Geertz não vale um tostão, mas vai saber por que ela tem tanto sucesso e há tanto tempo. A “cultura” não é um livro, mas um ser vivo que náo cessa de se modificar (Sahlins bem o mostrou); o próprio "informante" não pretende citar uma Bíblia porque ele bem sabe que a “cultura” está por tudo e todo o tempo; quanto a pretender ler o «livro» por cima dos ombros do nativo, isso diz somente que o etnólogo foi bem 
alimentado com leite e cereal em sua primeira infância, e que, por isso, é uma cabeça mais alto que o nativo.

14) Em que medida a prática do campo deveria ir além do nivel de uma exegese dominante tão documentada quanto possivel, como o fazem, porque não podem fazê-lo de outra forma, os historiadores tributários de suas fontes, e não de uma experiência de encontro?

Não está na definição de exegese que ela seja dominante: é, sobretudo, a humildade que é a regra nos comentários dos grandes textos religiosos. Além disso, nem o historiador nem o etnólogo são exegetas. O primeiro porque náo comenta um texto, mas uma infinidade de fontes, e porque constrói uma narração (história "acontecimental") ou uma análise. O segundo, o etnólogo, porque náo dispóe de um livro sagrado da cultura: ele produz comentários, mas também interpretaçôes, descriçôes, narrativas, generalizaçôes... Quanto à posição de dominante, ela é apenas cômica nos dois casos: por definição, o etnólogo, mesmo após vinte anos de campo, sabe menos que qualquer nativo sobre a cultura; e o historiador está em uma situaçáo ainda mais precária, ameaçado que está pela descoberta de novos arquivos.

Aliás, por que você opóe historiadores e etnógrafos? Veja o exemplo magnífico de Marshall Sahlins que, após o primeiro período de trabalho de campo, mergulhou nos arquivos das ilhas do Pacífico. O que é ou não é etnológico são as perguntas feitas, não a natureza das informaçôes. Sahlins perguntou-se como os havaianos haviam representado para si próprios a morte do capitão Cook: pergunta minúscula, que o conduziu a uma investigaçáo de muitos anos, um pouco junto a seres humanos vivos, e muito nos arquivos. Em Le Christianisme et ses juifs, partimos de uma pergunta ridiculamente limitada: por que os adversários cristãos da Paixão d'Oberammergau, a partir de 1931 (um punhado de pessoas), censuraram seu "antissemitismo" e não seu "antijudaísmo"? 


\section{A ESCRITA ETNOLÓGICA}

15) Você insiste sobre a temporalidade longa do trabalho etnográfico e sobre a necessidade do trabalho a posteriori sobre as anotaçóes de campo. Qual diferença você faz entre esses dois regimes da etnologia?

Antes de "regimes", termo que evoca uma organização, um programa, eu preferiria falar de "momentos" da pesquisa. Em "Ser afetado", mostrei que o trabalho etnográfico é um longo processo que exige disposiçôes não somente variadas, mas contraditórias entre si. Por sorte, não somos obrigados a mobilizar todas ao mesmo tempo. Mas por infelicidade, é preciso possuir todas, sem as quais esses anos de esforço não resultariam em uma etnografia, em um livro que comunica uma experiência de campo e que tenta pensar sobre a mesma. Também quis destacar a constante precariedade desse trabalho: cada uma dessas fases oferece inúmeras oportunidades de fazer a escolha errada. Seja quem for, enfim, que a tenha feito suficientemente bem para obter bons resultados, faria bem em se lembrar de que deve esse sucesso, em parte, ao acaso. Mesmo que se tenha fingido, durante os anos que separam um projeto de sua realização, que se prosseguia com a certeza da vitória final.

Hoje, eu acrescentaria isso. Uma vez que o etnógrafo terminou sua pesquisa, ele retorna à sua cidade e à sua universidade. Ele leva na cara as ideias pré-concebidas que, antes da sua partida, ele compartilhava em maior ou menor grau sem se dar conta. Sua velha tia, seus colegas, os jornalistas etc., cada um está seguro de saber o que é preciso pensar sobre a feitiçaria (o etnólogo não compartilharia esta certeza, é por isso que ele fez a investigação). Ora, essas pessoas que lhe fazem perguntas e dão respostas sobre o assunto são os primeiros representantes do público do livro por vir. É para fazer com que eles façam um certo trajeto, desde suas ideias pré-concebidas até um texto que lhe parece adequado à sua experiência, que o etnólogo quer escrever. E é estando saturado por aqueles discursos que ele vai reler as suas anotações de campo. 
De minha parte, tive de deixar passar dezoito meses antes de poder abrir meus arquivos: não tinha sido somente sacudida pela experiência, mas o que meus interlocutores parisienses esperavam de mim me paralisava. Quando pude reler minhas anotaçóes, eu estava enfim apta a instaurar um vai e vem entre meu diário de campo e as ideias pré-concebidas. Então, à escrita. Com uma dificuldade suplementar: eu sabia que eu seria lida no Bocage, onde os habitantes diziam sobre a feitiçaria as coisas mais contraditórias de acordo com o lugar que eles ocupam no momento em que falam. Decidi então tornar plausível a experiência dos enfeitiçados e de seus desenfeitiçadores para quem quer que aceitasse me seguir em um certo percurso textual. Corps pour corps é uma resposta às questóes dos leitores de Les mots, la mort, les sorts. Mas e você, como você entrou?

16) De que maneira e em que momento de seu percurso a evidência dos laços entre abordagem etnográfica e análise apareceu pra você??

Quando comecei a encontrar enfeitiçados os quais, relembro, falaram comigo porque acreditavam que eu era desenfeitiçadora e queriam me consultar, meus amigos e meus colegas etnólogos, Gellner inclusive, me desestimularam (Dan Sperber foi a única exceção à regra). No burburinho de maio de 68, eu tinha conhecido alguns analistas e tinha me vinculado a alguns dentre eles que vinham das ciências sociais, sobretudo ex-linguistas. E, além disso, eu havia começado uma terapia pessoal. Essas pessoas (inclusive meu analista) sempre me apoiaram em minha abordagem: discutimos ao longo de meses sobre os lugares nos quais meus interlocutores do Bocage me colocavam, sobre o projeto de descobrir um sistema desconhecido de lugares, etc. Naquele tempo, esses lacanianos não eram uniformemente sectários: eles não exigiam que minha etnografia constituísse uma aplicação direta de suas teorias. Rompemos os laços muito tempo depois, quando comecei a dizer que "sua" terapia era um caso particular dentre outros - o desenfeitiçamento, por exemplo.

Por outro lado, utilizei muito o texto de um psicanalista, Octave Mannoni, intitulado "Je sais bien... mais quand même", que analisa muito 
finamente a ambiguidade de um de seus pacientes em sua atitude com respeito à vidência. Mas somente retive a descrição, não toda a teorização (recheada de grandes palavras freudianas) que, para Mannoni, constituía seu principal aporte.

17) Após Writing Culture ${ }^{4}$ e a reescrita de suas anotaçóes de campo em Corps pour corps com Josée Contreras, como você pensa hoje o status da narração da experiência etnográfica?

Quando Writing Culture surgiu em 1986, eu já havia publicado quase toda minha obra sobre feitiçaria. Les mots, la mort, les sorts data de 1977, Corps pour corps de 1981, e nossos artigos sobre o desenfeitiçamento sucederam-se de 1983 a 1987 - alguns foram publicados mais tarde na França. A partir de 1985, fui frequentemente convidada para ir aos EUA em razão do interesse nascente pela escrita etnográfica. Mas havia muitos mal-entendidos entre nós, muitas imprecisóes sobre o que eles pesquisavam de fato, interesse demais pelo etnógrafo em si (às vezes até narcisismo), e deixei de ir para lá.

Somente nesses meses comecei a compreender por que esses dois primeiros livros tratavam sobre a narrativa: estou trabalhando um terceiro, Désorceler, que não trata disso (a ser lançado no próximo ano pelas Éditions de l'Olivier) ${ }^{5}$. Essa nova obra retoma a pesquisa que fizemos parcialmente em conjunto, Josée Contreras e eu, sobre o funcionamento do desenfeitiçamento. Assisti a cerca de duzentas sessóes de desenfeitiçamento, e registrei fragmentos de aproximadamente umas trinta entre elas. Trabalhamos minhas transcriçôes durante meses e descobrimos mecanismos dos quais eu não tinha tido a menor suspeita durante o campo.

É preciso lembrar que se trata de uma situação completamente banal. Da mesma forma, no campo das terapias psíquicas: nem o "paciente" nem seu terapeuta (malgrado as pretensóes teóricas de certas terapias sábias) percebem

4 Livro recém-traduzido para o português sob o título A escrita da cultura: poética e politica da etnografia (Papéis Selvagens, 2016). (N.T.)

5 Éditions de l'Olivier, 2009. (NT) 
o resultado efetivo da terapia. Ou ainda no campo da fala: ninguém pode ao mesmo tempo falar algo a alguém e saber o que se diz.

Poderia dizer que Josée Contreras e eu praticamos enfim a exegese textual, mas isso é falso: pesquisamos as instâncias ocultas de uma eficácia que se afirmava sessão após sessão, não as redes de significação das palavras. Lembro que esses textos nativos não caíram do céu (eu tive de ir ao local e ocupar um certo lugar para assistir às sessóes), e que elas não foram minha única fonte: eu dispunha também de minhas anotaçoes de diário (cheias de comentários dos enfeitiçados sobre suas sessôes) e de minhas lembranças.

Então, por que precisei das narrativas em Les mots, la mort, les sorts e Corps pour corps? Porque eu não via outra maneira de comunicar ao leitor um colega, um leitor da cidade interessado, um bocano ambivalente - uma experiência, a feitiçaria bocana, cuja literatura científica sobre a questáo e as ideias pré-concebidas do público não ofereciam nenhum saber prévio. Ademais, eu tinha tomado conhecimento dessa feitiçaria por uma prática de pesquisa que contrariava os preceptores da disciplina: na sequência, quando apresentei no Congresso da American Anthropological Association (Chicago, 1987) minha conclusão epistemológica e metodológica dos meus trabalhos sobre a feitiçaria, eu a intitulei "Sortir de l'anthropologie pour en faire" (ela foi publicada posteriormente na França sob o título "Ser Afetado"). Eu havia então praticado uma antropologia sobre a qual náo existia nenhum conhecimento prévio para abordar um fato social sobre o qual também não havia nenhum conhecimento prévio. $\mathrm{O}$ mais simples era ainda familiarizar o leitor com esse duplo estranhamento e propor narrativas que, juntas, trouxessem uma ou outra das dimensóes desse encontro. Em 2008, considero que este trabalho estará finalizado para os leitores: muitos já leram os dois primeiros livros ou podem encontrá-los em ediçóes de bolso. Portanto, náo precisam encontrar narrativas em Désorceler.

Além desses trabalhos sobre a feitiçaria, penso que a narrativa é necessária para os etnólogos (Sahlins, por exemplo) que veem a cultura como um processo em movimento perpétuo e náo como um estado, uma permanência (a antropologia estrutural). De minha parte, em Le Christianisme et ses juifs, 
experimento considerar a cultura sob o ângulo de sua colocação em ato, como um conjunto de práticas - de ações - cujos enunciados simbólicos fazem parte, e que produzem efeitos reparáveis no tempo histórico. Diria hoje que pratico uma antropologia pragmática, mas no começo dos anos 1970, quando concebi minha etnografia dos feitiços, a linguística pragmática estava ainda no limbo. De qualquer forma, você talvez tenha observado lendo Les mots, la mort, les sorts a que ponto eu me apoio nos trabalhos de Émile Benveniste (a enunciação e a subjetividade na linguagem). Diga-se de passagem, este grande pensador parte sempre de uma lista de casos empíricos e comunica suas reflexóes - tão frequentemente revolucionárias - em uma língua clara muito próxima da linguagem ordinária.

\section{PARA CONCLUIR}

18) Na perspectiva etnográfica clássica, a relação com o outro e a imersão em sua vida cotidiana permitem a compreensão de seu sistema simbólico. Você estudou inicialmente as relaçôes de força na feitiçaria bocana contemporânea; depois, os conflitos em torno de uma representação teatralizada e ritual existente há 300 anos; e, enfim, os casos internacionais de blasfêmia - como o caso Salman Rushdie ou as caricaturas do Profeta difundidas na Dinamarca. Como você negociou a passagem de um objeto de pesquisa a outro?

Sem dúvida, o trabalho de campo junto à população cujo "sistema simbólico" você gostaria de compreender é bem prático. Mas isso é uma facilidade, não uma necessidade. As culturas desaparecidas há muito tempo também deixaram inumeráveis traços que arqueólogos, historiadores e grupos de amantes dos "sistemas simbólicos" podem interrogar. As "representaçôes", assim como as "açôes", não são uma propriedade exclusiva dos raros humanos vivos que teriam a chance de viver ao alcance de um etnólogo! Este último nunca está, aliás, desprovido de perspectivas históricas ou de conhecimento 
livresco - sem falar dos ancestrais autóctones, cujas mensagens o pesquisador é obrigado a levar a sério.

Como passei de um objeto de pesquisa a outro? O que os une, desde meu começo na Argélia, é o meu fascínio pelas situaçōes de crise. Um acontecimento imprevisto - mas portador de uma questão vital - sobrevive; ele vira do avesso o estado de forças presente e requer uma mobilizaçáo; grupos de várias magnitudes entram em ação, cada um tentando ocupar ou não perder o lugar que lhe parece adequado para realizá-la. O caso se encerra de forma abrupta e decepcionante, com as partes resolvendo por um fim provisório das violências.

Tais crises vitais obrigam o pesquisador a encarar em conjunto a organização social e a ordem simbólica, a "estrutura", diria Sahlins. Os valores, as ideias, as instituiçôes, as pessoas, tudo entra de repente em funcionamento: estamos longe do simbólico visto como algo transcendental, uma supercausalidade que nenhum devir poderia afetar. É enfim na imanência, esse registro no qual os pequenos humanos do mundo sublunar que nós todos somos (etnólogos inclusive) se debatem como podem.

\section{Traduzido por Marco Antonio Saretta Poglia e Melissa Moura Mello.}

Entrevista publicada originalmente em:

FAVRET-SAADA, Jeanne; ISNART, Cyril. En marge du dossier sur l'empathie en anthropologie. Journal des anthropologues, n. 114-115, p. 203-209, 2008.

Os tradutores e a revista Debates do NER agradecem a Jeanne Favret-Saada e ao Journal des anthropologues pela cessão dos direitos de traduçáo de publicaçáo desta entrevista. 


\section{REFERÊNCIAS}

CLIFFORD, J.; MARCUS, G. E. (Ed.). Writing Culture: The Poetics and Politics of Ethnography. Berkeley: University of California Press, 1987.

FABRE-VASSAS, C. La bête singulière: les juifs, les chrétiens et le cochon. Paris: Gallimard, 1993.

FAVRET-SAADA, J. Les mots, la mort, les sorts: la sorcellerie dans le bocage. Paris: Gallimard, 1977. . Être affecté. Gradhiva, n. 8, p. 3-10, 1990. . Algérie 1962-1964: Essais d'anthropologie politique. Paris: Éditions Bouchène, 2005.

. Comment produire une crise mondiale avec douze petits dessins. Paris: Les Prairies Ordinaires, 2007.

FAVRET-SAADA J.; CONTRERAS J. Corps pour corps: Enquête sur la sorcellerie dans le Bocage. Paris: Gallimard, 1981. . Le christianisme et ses juifs: 1800-2000. Paris: Seuil, 2004.

GEERTZ, C. Bali: interprétation d'une culture. Paris: Gallimard, 1973. MANNONI, O. Clefs pour l'imaginaire ou l'autre scène. Paris: Seuil, 1969.

Recebido em: 03/10/2017 Aprovado em: 03/10/2017 



\section{RESENHAS}





\section{SUÁREZ, HUGO JOSÉ. CREYENTES URBANOS: SOCIOLOGÍA DE LA EXPERIENCIA RELIGIOSA EN UNA COLONIA POPULAR DE LA CIUDAD DE MÉXICO. MÉXICO: UNIVERSIDAD NACIONAL AUTÓNOMA DE MÉXICO, 2015.}

\section{Karina Bárcenas Barajas ${ }^{l}$}

Cualquier teoría general de la ciudad debe de alguna manera relacionar los procesos sociales en la ciudad con la forma espacial que asume. En términos disciplinarios, esto equivale a integrar dos importantes tradiciones educativas y de investigación - lo llamo construir un puente entre los poseedores de la imaginación sociológica y aquellos imbuidos de una conciencia espacial o una imaginación geográfica.

David Harvey ${ }^{2}$

En su obra Creyentes Urbanos, Hugo José Suárez conjuga la imaginación sociológica y la imaginación geográfica para situarse en un escenario de la Ciudad de México, la colonia Ajusco, que representa un gran espacio de observación de lo religioso y de la vida social en general por su constitución como un territorio y por su dinámica cultural suburbana. Como lo señala el autor, "en un terreno de piedras, se tuvo que construir una sociedad con todo lo que ello implica: traer sus dioses y demonios, relacionarse con el Estado, construir sociedad y hacer, de y entre lava volcánica un 'lugar"” (Suárez, 2015, p. 16).

A partir de la dinámica sociocultural suburbana del Ajusco el autor dialoga con las grandes transformaciones que han marcado la dinámica del campo religioso en las últimas décadas: la diversidad religiosa, los procesos de institucionalización y desinstitucionalización religiosa y la individua-

1 Dra. en Ciencias Sociales con Especialidad en Antropología Social. Investigadora Asociada en el Instituto de Investigaciones Sociales de la Universidad Nacional Autónoma de México (UNAM). Contacto: kb.barcenas@gmail.com

2 Harvey (2009, p. 23). 
lización de las creencias. Dichos procesos han impactado en la manera cómo los creyentes en la colonia Ajusco viven su religiosidad y configuran su identidad religiosa, por lo que, desde esta perspectiva el autor coloca la mirada en el sujeto creyente, sin desatender el análisis del campo religioso.

Fiel a su habitus sociológico, Hugo José Suárez construye una sociología de los creyentes que le permite analizar la composición del campo religioso en un diálogo que prioriza las estructuras y la oferta religiosa local, enraizada en la colonia Ajusco, pero manteniendo una relación constante con los debates globales sobre la creencia y la pertenencia religiosa.

La estructura del libro se compone de tres partes que van de la deconstrucción de un modo de observación de lo religioso a el análisis del territorio, el campo y las disposiciones e individuación de los creyentes. En la primera parte, El punto de vista, Hugo José Suárez presenta un gran trabajo de deconstrucción de su modo de observación de lo religioso en el que siguiendo a Max Weber plantea su interés por "lo pragmático de las religiones" por sus formas históricas, por la "diversidad polifacética de sus condiciones" (Suárez, 2015, p. 32).

Desde esta perspectiva es que dicho modo de observación de lo religioso prioriza la experiencia de los creyentes, "sus maneras de encontrar respuestas religiosas en la vida diaria [...] sus disposiciones para dar sentido a sus prácticas" (Suárez, 2015, p. 34), o como lo plantea el autor en términos de Pierre Bourdieu "los habitus religiosos individuales" (Suárez, 2015, p. 38). $\mathrm{Si}$ consideramos que tanto la experiencia como el individuo son centrales para la sociología contemporánea, podemos plantear que la obra Creyentes Urbanos aporta una perspectiva importante para situarse en estos debates.

La observación sobre lo religioso del autor incorpora un análisis de los grandes desplazamientos teóricos para explicar el comportamiento religioso en México: "de la disidencia a la mutación, de la mutación a la diversidad, [y] de la diversidad a la pluralidad en la diversidad" (Suárez, 2015, p. 47), así como las particularidades históricas de la colonia Ajusco que, desde su perspectiva, responden a "una compleja articulación de lógicas heredadas 
de la cultura campesina migrante en la ciudad, pueblos originarios cercanos, y dinámicas tradicionalmente urbanas y modernas" (Suárez, 2015, p. 59).

En la segunda parte, Territorio, campo y orientaciones religiosas, Hugo José Suárez responde sociológicamente a la interrogante "¿Cómo se construye un territorio y en él una sociedad local?” (Suárez, 2015, p. 69). Además, los lectores encontrarán un panorama sobre la composición del campo religioso en la colonia Ajusco, del cual se desprenden cuatro maneras de creer:

1. Los tradicionales institucionalizados, que cumplen con las leyes y obligaciones y que participan en la vida eclesial.

2. Los tradicionales desinstitucionalizados, que consideran que para ser buen creyente no es necesario ni cumplir con los deberes religiosos, ni conocer con mayor profundidad la doctrina católica.

3. Los innovadores institucionales, que tienen una relación estrecha con la institución - la necesitan y participan en ella - pero no acatan los mandatos oficiales.

4. Los innovadores autónomos, que creen a su manera lejos de la iglesia y no tienen preocupación por la doctrina, los más jóvenes se ubican en esta categoría (Suárez, 2015, p. 171, 177).

La tercera parte, Disposición e individuación: los creyentes, se inscribe en las lógicas de la heterodoxia y la heterogeneidad, es decir en los procesos de diferenciación al interior del catolicismo y en lo que el autor denomina "creencias bisagra" (Suárez, 2015, p. 174), que articulan las creencias tradicionales con las nuevas creencias, como la religiosidad popular, las religiones emergentes, como la santería y la Santa Muerte. Dicha heterodoxia y heterogeneidad también está en relación con las variables género y generación, las cuales son "determinante[s] en la experiencia religiosa" (Suárez, 2015, p. 55).

Finalmente, si consideramos que la versión impresa del libro incluye un $\mathrm{CD}$ que mediante una estructura de página web muestra, como lo señala el autor, "otra[s] ruta[s] para adentrarse en las dinámicas religiosas" se puede plantear que la sociología de los creyentes de Hugo José Suárez se presenta a 
los lectores a través de una narrativa transmedia, que de acuerdo con Carlos Scolari (2013) ocurre cuando una historia es contada a través de diversos medios o plataformas tecnológicas.

El contenido del CD también se puede consultar en el sitio web de Creyentes Urbanos ${ }^{3}$. En ambos soportes tecnológicos, la sociología de los creyentes se muestra a través de una cartografía de la colonia Ajusco, con las rutas y mapas de las peregrinaciones, series fotográficas sobre la diversidad de expresiones religiosas en el Ajusco, videos en los que la voz del autor nos sitúa en otra perspectiva religiosa y territorial del Ajusco, así como la base de datos de la Encuesta de la Experiencia Religiosa en la Colonia Ajusco.

Creyentes urbanos es una obra altamente recomendable para todos los interesados en la experiencia religiosa de los creyentes y en las grandes transformaciones del campo religioso en México ocurridas durante las últimas décadas, a través de una narrativa dirigida por la voz del investigador pero que también privilegia la voz de sus informantes.

\section{REFERENCIAS}

HARVEY, David. Social Justice and The City. Atenas: The University of Georgia Press, 2009.

SCOLARI, Carlos. Narrativas Transmedia: cuando todos los medios se encuentran. Barcelona: Deusto, 2013.

SUÁREZ, Hugo José. Creyentes urbanos: Sociología de la experiencia religiosa en una colonia popular de la Ciudad de México. Ciudad de México: Universidad Nacional Autónoma de México, 2015.

Recebido em: 03/01/17

Aprovado em: 04/02/17

3 Disponível em: <http://creyentesurbanos.com>. Acesso em: 4 jan. 2017. 


\section{VERKAAIK, OSKAR (ORG.). RELIGIOUS ARCHITECTURE: ANTHROPOLOGICAL PERSPECTIVES. AMSTERDAM: AMSTERDAM UNIVERSITY PRESS, 2013.}

\section{Adriano Santos Godoy ${ }^{l}$}

A coletânea Religious architecture: anthropological perspectives parte de um aparente paradoxo. Por um lado, os próprios religiosos argumentam que a edificação de grandes templos é uma questão do passado, e que contemporaneamente as religióes têm abandonado esse objetivo, e se preocupado com questóes mais subjetivas e menos suntuosas. Do mesmo modo, as etnografias do campo de estudo da religiáo se não colocam o templo em segundo plano, costumam o abordar com um recorte histórico muito específico, que dialoga pouco com seus usos diários. Assim, costuma se tirar a conclusão de que os motivos da edificação de templos seriam apenas sociopolíticos em detrimento dos religiosos. Por outro lado, e contradizendo tudo isso, o que se observa empiricamente é que de maneira contínua são anunciadas grandes empreitadas, seja de construção como de reformas de templos ao redor do mundo.

Oskar Verkaaik, professor da Universidade de Amsterdam e organizador da coletânea, a partir desse cenário e dessas premissas, faz a tradicional pergunta antropológica de como conciliar o que os nativos dizem do que eles fazem. A primeira constatação é de que há um erro epistemológico na divisão, usualmente feita, na qual há a constatação da importância sociopolítica em detrimento da importância religiosa. Trazendo a teoria e abordagem proposta pelo antropólogo Talal Asad (2010), argumenta-se que essa divisão não é satisfatória analiticamente e deve ser abolida: os aspectos sociopolíticos são os mesmos que os aspectos religiosos.

1 Doutorando em Antropologia Social pela Unicamp. Pesquisador do Laboratório de Antropologia da Religião. Contato: adrianosgodoy@gmail.com 
Com um levantamento bibliográfico preciso, ele não desenvolve o erro comum de se autoproclamar o pioneiro nesse tema, e sim indicar como uma questão latente na disciplina apenas não foi suficientemente evidenciada. Verkaaik demonstra que autores como Clifford Geertz, Edmund Leach, Maurice Bloch, Pierre Bourdieu e Marc Auge já teriam abordado a questão da arquitetura em suas obras. E é nesse movimento que a apresentação clama para si o objetivo de organizar um campo de estudos, indicado no título, e que julga ser pouco explorado: as perspectivas antropológicas da arquitetura religiosa.

Ao remontar alguns clássicos da disciplina, evidenciam-se como questôes tangentes as construçóes e a arquitetura são evocadas etnograficamente, mas raramente são abordadas analiticamente. À exceção, as abordagens desses casos seguem justamente os preceitos sociopolíticos, seja funcional ou estruturalmente. O motivo dessa ausência não estaria na falta de interesse, e sim na epistemologia das Ciências Sociais que, por muito tempo, outorgaram essa tarefa para a História da Arte.

Ao propor a aproximação com a história da arte e a crítica arquitetônica, o autor defende que a antropologia não só teria muito que aprender, mas principalmente o que contribuir, já que tratando de temas próximos, não forjariam análises semelhantes por partirem de premissas distintas. Nas suas próprias palavras:

Ao invés de tentar decifrar os significados de autoridade de um edifício - ou seja, a opiniâo do arquiteto, o comissário ou críticos de arquitetura - uma perspectiva antropológica concentra-se nas mudanças e nos conflitos em práticas produtoras de significado. Tomadas em conjunto, as abordagens interacionistas e contextuais interpretativas permitem uma perspectiva sobre edifícios como mais do que apenas objetos passivos ou textos transmitindo uma mensagem estática (Asad, 2010, p. 13).

De fato, é esse o fio condutor da coletânea de artigos que, ao partir de contextos profundamente distintos, tem como eixo comum as práticas produtoras de significado em torno de templos religiosos. 


\section{AS MULTIPLICIDADES ARQUITETÔNICAS, RELIGIOSAS E METODOLÓGICAS}

No primeiro dos capítulos, Richard Irvine explora "o papel ativo dos edifícios na vida Beneditina, e o papel crucial que a arquitetura desempenha na construção de uma identidade Beneditina inglesa" (Verkaaik, 2013, p. 25, grifo do autor, tradução nossa). Ao etnografar a rotina em um mosteiro, além das especificidades historiográficas da Inglaterra pós-reforma, o autor desenvolve a ideia de que a arquitetura monástica é "contrafatual”, e está em consonância com a promoção dos rituais católicos de coletividade.

Ainda nos aspectos arquitetônicos do catolicismo, em outro capítulo é Mattijs van de Port quem desenvolve uma etnografia da Igreja de São Francisco, em Salvador. Com um texto provocativo, que parte de sensaçóes corpóreas como a ereção de mamilos, o autor evita propositalmente a densa discussão historiográfica sobre o barroco brasileiro, para demonstrar que "o corpo é um meio tanto quanto a igreja. Ambos são instrumentos de produção de sensaçóes" (Verkaaik, 2013, p. 63, tradução nossa). A arquitetura religiosa seria, como o corpo, um sistema de mediação com o sagrado.

Tobias Köllner traz o terceiro capítulo que trata da arquitetura cristá, mas em uma perspectiva completamente distinta das anteriores, já que “está menos preocupado com a arquitetura de edifícios religiosos do que com os fundamentos religiosos, morais e sociais das atividades de construção" (Verkaaik, 2013, p. 94, tradução nossa). Ao analisar a construção e a restauração de igrejas ortodoxas na Rússia contemporânea, o autor demonstra como o reavivamento religioso é uma empreitada, fortalecida pela parceria entre o Estado e a Igreja, em um contexto pós-soviético.

O único capítulo sobre um templo hindu é o de Markha Valenta que, através do caso de Siddhivinayak, demonstra como a Índia nacionalista e rural do contexto da independência tem cada vez mais dado lugar a uma Índia neoliberal e urbana. Nesse sentido também aquele espaço muda seu status: "a capacidade do templo de mobilizar pessoas de todas as classes e origens da cidade, do país e do mundo para vir para o seu pátio” (Verkaaik, 2013, p. 105, tradução nossa). 
Também há um único capítulo sobre o templo judaico, localizado na cidade italiana de Florença. Ivan Kalmar analisa o contexto de construção da sinagoga, no século XIX, conhecida pelo seu "estilo mouro". Contrariando o senso comum local, e repetido pelos guias turísticos, é demonstrado que "isso não tem nada a ver com nostalgia da Espanha, mas sim expressa a crença de que judeus, como primo dos árabes, devem construir em um estilo oriental e não europeu" (Verkaaik, 2013, p. 179, tradução nossa). O autor termina com o indicativo de que os mesmos desafios historicamente enfrentados pelos judeus, na construçáo de seus templos europeus, parece ser aquele enfrentado contemporaneamente pelos muçulmanos naquele mesmo continente. Dos quatro artigos sobre mesquitas muçulmanas, três abordam essa questão.

Pooyan Tamimi Arab analisa a construçáo de uma mesquita em Rotterdam, a partir da polêmica de que ela seria a maior mesquita da Europa. Demonstrando que ela não é nem mesmo a maior mesquita holandesa, o autor aborda as tensôes diárias e recorrentes entre europeus e migrantes árabes já que "arquitetura religiosa engendra discursos explícitos de identidade, literalmente uma forma material para exigir o reconhecimento do direito a cidade" (Verkaaik, 2013, p. 58, tradução nossa).

No contexto britânico, Shahed Saleem aborda a construção de mesquitas em uma metrópole multicultural como Londres. Com um número elevado de pessoas, advindas de contextos distintos, não há uma referência arquitetônica direta a uma única identidade ou vertente islâmica. "Elas, portanto, servem como centro para uma comunidade muçulmana globalizante, $\mathrm{e}$ efetuam uma mudança em direção a uma forma genérica da prática religiosa" (Verkaaik, 2013, p. 191, tradução nossa).

O caso da mesquita de Granada é bem distinto, como demonstra Oskar Verkaaik. Tratando-se de muçulmanos espanhóis convertidos, ou seja, que diferente dos últimos dois artigos não são imigrantes, a construção da mesquita em um bairro periférico evoca o reavivamento uma tradição islâmica perdida após a recolonização católica. Como os referenciais são 
majoritariamente arquitetônicos e artísticos, "ser um muçulmano convertido na Andaluzia é uma profunda experiência estética” (Verkaaik, 2013, p. 149, tradução nossa).

Por fim, no único contexto africano, Trevor Marchand faz uma etnografia do ritual anual de manutenção da mesquita de Djneé, no Mali, conhecida como a maior construção de barro do mundo. Ao envolver a população local, o evento acontece como uma espécie de fórum e oficina, ao mesmo tempo de arquitetura local e de religião islâmica. A sua análise demonstra que aquele templo "não é apenas um lugar de oração ou um objeto estético para a preservação histórica. Possivelmente mais importante, é um edifício construído, mantido e, pode-se adicionar, perpetuamente transformado por sua comunidade" (Verkaaik, 2013, p. 140, tradução nossa). Esteticamente surpreendente, é essa construção que estampa a capa do livro.

\section{AS MATERIALIDADES DA RELIGIÃO}

Como se pode perceber, com uma variedade geográfica e religiosa considerável, essa coletânea de artigos converge na intenção de uma abordagem antropológica da arquitetura religiosa. Essa convergência disciplinar, contudo, não coincide com uma convergência metodológica. A pluralidade de métodos empregados nas análises, desenvolvidas nos artigos e ilustrada pelo caderno de fotografias, enriquece a publicação ao demonstrar as diversas formas possíveis investidas da disciplina em relação ao tema.

Entretanto, essas abordagens não se resumem àquela evocada na apresentação feita pelo organizador. Segundo Oskar Verkaaik (2013, p. 9, tradução nossa), "as recentes contribuiçóes antropológicas mais relevantes, para o estudo da religião contemporânea, estão na crítica a esta desconexão do imaterial e a matéria”.

Para essa afirmação, o autor tem como referência os autores do chamado "Material-Cultural Turn” (Hicks, 2010) que propóem uma metodologia de 
construção do conhecimento antropológico em que a cultura material seja trazida de volta ao centro das discussões dessa disciplina.

Dentre toda a bibliografia mobilizada por Verkaaik, a esse respeito, elencarei apenas algumas mais centrais no seu argumento. Um exemplo é a coletânea organizada por Arjun Appadurai (2008) que, diferente de outros autores desse tema, recebeu uma tradução na língua portuguesa e teve alguma influência na antropologia brasileira. A sua contribuição estaria justamente na concepçáo de "vida social das coisas", já que consegue abordar como as obras arquitetônicas, a partir das suas próprias materialidades, desenvolvem diferentes significados com o passar do tempo.

Nessa mesma esteira há referências às obras de Daniel Miller e de Alfred Gell que, também ao etnografar a materialidade das coisas, passam a questionar a natureza objetiva dos chamados objetos. Eles demonstram que certas coisas, sem vida fisiológica, não necessariamente são objetos e sim sujeitos sociais. Assim, a obra arquitetônica tem essa potencialidade de agência, e enquanto um sujeito social capaz de estabelecer relaçóes.

Evocando Tim Ingold, que tem abordado temas caros a arquitetura, Verkaaik ressalta que se sua metodologia se mostra eficaz para "explorar como as pessoas se posicionam no ambiente natural, mas eles dão menos atenção em como as pessoas o fazem em ambientes construídos" (Verkaaik, 2013, p. 11, tradução nossa). Ao invés disso, a constatação da relaçáo entre coisas e pessoas em ambientes construídos, e a zona nebulosa que a arquitetura habita nesse contexto, leva o organizador da coletânea a evocar preferencialmente a teoria do ator-rede de Bruno Latour, e mesmo Gregory Bateson.

Em suma, os autores citados na apresentação trazem questóes epistemológicas a respeito de como a antropologia deve abordar as coisas em suas materialidades. À medida que sintetiza os principais argumentos de cada um deles, o organizador faz um esforço de indicar como seriam proveitosos nas pesquisas sobre arquitetura de maneira geral. Entretanto, o que se nota é que nem a arquitetura religiosa e nem mesmo a religiáo são a questão para esses autores, e aí está o seu valor. 
Dessa maneira, tanto na apresentaçáo da coletânea como em seu artigo, Oskar Verkaaik tem como principal interlocutora a sua conterrânea Birgit Meyer (2009), professora da Universidade de Utrecht. Através do seu conceito de "forma sensacional" ele concorda que a "religião contemporânea não é meramente um envolvimento mental e ético com a doutrina religiosa, mas um profundo comprometimento performativo e estético" (Verkaaik, 2013, p. 9, tradução nossa). A religiáo é também uma experiência estética, e a arquitetura é fundamental para proporcioná-la.

Birgit Meyer (2009), assim como David Morgan (2011), tem fomentado a proposta de levar a questáo da materialidade para o centro das pesquisas em religião, e Oskar Verkaaik aposta nessa perspectiva para uma abordagem da arquitetura religiosa. Assim, sem abrir mão da linha argumentativa de Asad (2010), ele faz questão de ressaltar que se tratando de religião, a política e as coisas são táo importantes quanto as crenças.

Se a potência das materialidades é mais evidente no campo da religiáo, vale ressaltar que a arquitetura não se restringe a ele. Nesse sentido, a coletânea Religious architecture: anthropological perspectives é também um manifesto metodológico mais abrangente, que além de apresentar uma gama de autores que pensam esta questão em outros termos, também indica os referenciais bibliográficos capazes de abordá-la de maneira mais profícua.

\section{REFERÊNCIAS}

APPADURAI, Arjun. A vida social das coisas: as mercadorias sob uma perspectiva cultural. Niterói: EdUFF, 2008.

ASAD, Talal. A construção da religião como categoria antropológica. Cadernos de Campo, São Paulo, n. 19, p. 263-284, 2010.

HICKS, Dan. The Material-Cultural Turn: event and effect. In: Hicks, Dan; Beaudry, Mary C. (Ed.). The Oxford Handbook of Material Culture Studies. Oxford: Oxford University Press, 2010. 
MEYER, Birgit. Aesthetic Formations: Media, Religion, and the Senses. Houndmills: Palgrave, 2009.

MORGAN, David. Religion and Material culture: the matter of belief. London: Routledge, 2011.

VERKAAIK, Oskar (Org.). Religious architecture: anthropological perspectives. Amsterdam: Amsterdam University Press, 2013.

Recebido em: 17/12/16 Aprovado em: 04/01/17 


\section{DIRETRIZES PARA AUTORES}

1) A Revista Debates do NERé um periódico publicado semestralmente pelo Núcleo de Estudos da Religião (NER), do Programa de Pós-Graduação em Antropologia Social da Universidade Federal do Rio Grande do Sul (UFRGS). Tem como objetivo divulgar textos científicos inéditos, decorrentes de pesquisas nacionais e internacionais realizadas na área das ciências sociais, relativas à religião enquanto fato social em suas interfaces com outras esferas da sociedade. Os trabalhos submetidos deverão ter relevância acadêmica e social.

2) O manuscrito que for submetido a publicação nesta Revista deverá ser original e inédito, não podendo, portanto, estar simultaneamente submetido a publicação ou estar publicado em outros periódicos, livros ou quaisquer outras formas de divulgação acadêmica.

3) A Debates do NER publica trabalhos em português e espanhol. Desse modo, os trabalhos submetidos para publicação deverão ser redigidos em uma dessas línguas, sempre obedecendo as normas de bom uso das mesmas.

4) Os originais deverão ser submetidos pela internet, mediante cadastro de todos os autores no site da Revista (http://seer.ufrgs.br/debatesdoner/user/register).

5) A publicação dos artigos será condicionada à aprovação da Comissão Editorial Executiva, considerando pareceres de consultores externos, reconhecidos nas temáticas abordadas na Debates do NER. Essa avaliação é feita por pelo menos dois desses consultores externos, de forma cega, para assegurar a integridade e isençáo dos pares. Todavia, fica a cargo da Comissão Editorial Executiva selecionar entre os originais aprovados pelos consultores, quais serão publicados em cada edição.

6) Para garantir a avaliação cega por parte dos pares, os dados do(s) autor(es) não serão encaminhados aos consultores, entretanto, é responsabilidade do(s) autor(es) certificar-se de que não existem - em nenhum lugar do corpo do texto ou nas propriedades do arquivo - dados que possam identifica-los. Para remover a identificação das propriedades do arquivo, o autor dos originais deve realizar os seguintes procedimentos: 
a. Em documentos do Microsoft Office ou Mac: (no menu Arquivo > Propriedades), iniciando em Arquivo, no menu principal, e clicando na sequência: Arquivo > Salvar como... > Ferramentas (ou Opçóes no Mac) > Opçóes de segurança... > Remover informaçóes pessoais do arquivo ao salvar $>$ OK $>$ Salvar.

b. Em PDFs, os nomes dos autores também devem ser removidos das Propriedades do Documento, em Arquivo no menu principal do Adobe Acrobat.

7) A Debates do NER a cada número publica dois tipos de textos: artigos e resenhas. Cada um desses trabalhos tem características com relação a conteúdo e número de páginas que deverão ser observados pelos autores:

a. Artigos (15-25 páginas): Relatos de investigações originais, baseados em pesquisas sistemáticas e completas, realizadas com as devidas metodologias e análises científicas. Também serão admitidos, porém em número limitado, artigos teóricos ou de revisóes sistemáticas e atuais sobre temas relevantes para a linha editorial da revista, que conte com análise crítica e oportuna de um corpo abrangente de pesquisa, relativa a temas que contribuam para o desenvolvimento das Ciências Sociais da Religião, preferencialmente num campo de investigação para a qual o(a) autor(a) contribui.

b. Resenhas (3-10 páginas): Análise crítica de obras publicadas recentemente (máximo quatro anos), norteando o(a) leitor(a) quanto às suas características e explicitando usos potenciais. Antes de submeter esse tipo de trabalho, os(as) autores(as) deverão consultar a Editora Geral.

8) Os critérios que serão avaliados nos artigos submetidos à publicação são os seguintes:

a. Quanto à estrutura: Qualidade da estrutura lógica do trabalho no que se refere à organização dos tópicos que o compóem.

b. Quanto à redação: Será avaliada a clareza do texto, a qualidade ortográfica e gramatical, além de argumentação elucidada com rigor e propriedade;

c. Quanto à qualidade técnica e científica: Serão analisados o emprego correto dos conceitos abordados, a adequação e a profundidade dos conteúdos bem como o rigor científico do trabalho. 
d. Quanto à originalidade: Serão levados em conta o ineditismo e o grau de inovação proposto pelo trabalho, além da expressividade e importância do trabalho, para a discussão de problemas de seu campo de investigação;

e. Atualidade e pertinência das referências utilizadas.

9) Os manuscritos submetidos deverão ter folha de rosto contendo: Título completo do trabalho, em português ou espanhol, juntamente com sua versão em inglês, resumo (entre 100 e 150 palavras) com espaço simples, no idioma do artigo e sua respectiva versão em inglês e palavras-chave (máximo quatro) também no idioma do artigo, com sua respectiva versão em inglês. Além disso, deverá conter nome(s) completo(s) do(s) autor(es), suas titulações máximas, o nome completo da(s) instituição(ões) onde atua(m) e a posição do(s) mesmo(s) em tal(is) instituição(óes). Também deverão constar os seguintes dados de contato: Endereço completo, e-mail e telefones (recomenda-se utilizar endereços institucionais, tanto para correspondência física quanto eletrônica).

10) Após encaminhado e avaliado pelos pares, a equipe editorial entrará em contato com o autor principal, para informar o veredito, que poderá ser de aceito, aceito com alteraçôes ou de recusado. Em qualquer desses casos, o material enviado não será devolvido.

11) Em caso de dúvidas, os autores poderão entrar em contato com a equipe editorial através do e-mail: debatesdoner@gmail.com, ou com o departamento do Antropologia Social da Universidade Federal do Rio Grande do Sul, pelo telefone: 33086638.

12) Os artigos devem ser escritos em fonte Times New Roman 12 . O texto deverá estar justificado, e em formato A4 (210x297), com espaço de 1,5 e ter até 8 mil palavras (artigos) e até 4 mil palavras (resenhas), incluindo título, resumo, palavras-chave, referências e notas. Inicial maiúscula deverá ser usada somente quando imprescindível e os recursos tipográficos devem ser utilizados uniformemente:

a. itálico: para palavras estrangeiras, títulos (livros, eventos etc.) e ênfase;

b. aspas duplas: citações diretas com menos de três linhas, citações de palavras individuais ou palavras cuja conotação ou uso mereça destaque;

c. negrito e sublinhado: devem ser evitados. 
13) Para citações bibliográficas, os autores deverão se guiar pelas normas da ABNT, de modo que no corpo do texto, a indicação de referência nas citaçóes diretas deve trazer autor(es), ano de publicação e página(s); nas citaçôes indiretas, a indicação de página é opcional, conforme os modelos:

a. Segundo Hassen (2002, p. 173): "Há uma grande carência de materiais didáticos nesse campo, principalmente se aliados à ludicidade."

b. Sabemos da grande carência de materiais didáticos nesse campo, segundo Hassen (2002, p. 173).

14) As citaçóes diretas com mais de três linhas, no texto, devem ser destacadas com recuo de quatro espaços à direita da margem esquerda e corpo menor de letra, sem aspas, em espaço simples; transcriçóes das falas dos informantes seguem a mesma norma. Além disso, as notas explicativas devem ser numeradas ordinalmente no texto e vir no rodapé da página

15) Os desenhos, as fotografias, as tabelas, os gráficos, os mapas, dentre outros elementos representativos, deverâo estar devidamente numerados, com o título e com a fonte consultada. Os autores deverão atentar ainda para a qualidade de tais itens, de modo a garantir a fidedignidade dos mesmos, tanto na reproduçáo quanto na impressão.

16) A Debates do NER não se responsabiliza, sob nenhuma circunstância, pelos conceitos enunciados pelos autores. Ao enviar seu material, o autor cede instantaneamente os direitos autorais de forma integral ao PPG em Antropologia Social da UFRGS.

17) Os autores de artigos ou resenhas receberão dois exemplares da revista na qual seus trabalhos forem publicados.

18) As referências devem vir após o texto, ordenadas alfabeticamente, seguindo as normas da ABNT, conforme os modelos: 
a) Livro (e guias, catálogos, dicionários etc.) no todo: autor(es), título (em itálico e separado por dois-pontos do subtítulo, se houver), número da edição (se indicado), local, editora, ano de publicação:

DUMONT, Louis. Homo hierarchichus: o sistema de castas e suas implicações. São Paulo: EDUSP, 1992.

FORTES, Meyer; EVANS-PRITCHARD, Edward. (Org.). African political systems. Oxford: Oxford University Press, 1966.

MINISTÉRIO DE SALUD. Unidade Coordinadora Ejecutora VIH/SIDA y ETS. Boletín de SIDA: programa nacional de lucha contra los retrovirus del humano y SIDA. Buenos Aires, mayo 2001.

b) Parte de livro (fragmento, artigo, capítulo em coletânea): autor(es), título da parte seguido da expressão "In:", autor(es) do livro, título (em itálico e separado por dois pontos do subtítulo, se houver), número da edição (se indicado), local, editora, ano de publicação, página(s) da parte referenciada:

VELHO, Otávio. Globalização: antropologia e religião. In: ORO, Ari Pedro; STEIL, Carlos Alberto. Globalização e religiāo. Petrópolis: Vozes, 1997. p. 25-42.

c) Artigo/matéria em periódico (revista, boletim etc.): autor(es), título do artigo, nome do periódico (em itálico), local, ano e/ou volume, número, páginas inicial e final do artigo, data.

CORREA, Mariza. O espartilho de minha avó: linhagens femininas na antropologia. Horizontes Antropológicos, Porto Alegre, ano 3, n. 7, p. 70-96, out. 1997.

d) Artigo/matéria em jornal: autor(es), título do artigo, nome do jornal (em itálico), local, data, seção ou caderno, página (se não houver seção específica, a paginação precede a data):

TOURAINE, Alain. O recuo do islamismo político. Folha de São Paulo, São Paulo, 23 set. 2001. Mais!, p. 13. SOB as bombas. Folha de São Paulo, São Paulo, p. 2, 22 mar. 2003. 
e) Trabalhos acadêmicos: referência completa seguida do tipo de documento, grau, vinculação acadêmica, local e data da defesa, conforme folha de aprovação (se houver):

GIACOMAZZI, Maria Cristina Gonçalves. O cotidiano da Vila Jardim: um estudo de trajetórias, narrativas biográficas e sociabilidade sob o prisma do medo na cidade. 1997. Tese (Doutorado em Antropologia Social) - PPGAS/UFRGS, Porto Alegre, 1997.

f) Evento no todo: nome do evento, numeração (se houver), ano e local (cidade) de realizaçáo, título do documento (anais, atas, resumos etc., em itálico), local de publicação, editora e data de publicação:

REUNIÃO DA ASSOCIAÇÃO BRASILEIRA DE ANTROPOLOGIA, 21., 1998, Vitória. Resumos... Vitória: Departamento de Ciências Sociais/UFES, 1998.

g) Trabalho apresentado em evento: autor(es), título do trabalho apresentado seguido da expressão "In:", nome do evento, numeração (se houver), ano e local (cidade) de realização, título do documento (anais, atas, resumos etc., em itálico), local de publicação, editora, data de publicação e página inicial e final da parte referenciada:

STOCKLE, Verena. Brasil: uma nação através das imagens da raça. In: REUNIÃO DA ASSOCIAÇÃO BRASILEIRA DE ANTROPOLOGIA, 21., 1998, Vitória. Resumos... Vitória: Departamento de Ciências Sociais/UFES, 1998. p. 33.

\section{CONDIÇÕES PARA SUBMISSÃO}

Como parte do processo de submissão, os autores são obrigados a verificar a conformidade da submissão em relação a todos os itens listados a seguir. As submissóes que não estiverem de acordo com as normas serão devolvidas aos autores.

1) A contribuição é original e inédita, e não está sendo avaliada para publicação por outra revista; caso contrário, justificar em "Comentários ao Editor".

2) Os arquivos para submissão estão em formato Microsoft Word, OpenOffice ou RTF (desde que não ultrapasse os $2 \mathrm{MB}$ )

3) Todos os endereços de páginas na Internet (URLs), incluídas no texto (Ex.: http://www.ibict.br) estão ativos e prontos para clicar. 
4) O texto está em espaço 1,5; usa uma fonte de 12-pontos; emprega itálico ao invés de sublinhar (exceto em endereços URL); com figuras e tabelas inseridas no texto, e não em seu final.

5) O texto segue os padróes de estilo e requisitos bibliográficos descritos em Diretrizes para Autores.

6) A identificação de autoria deste trabalho foi removida do arquivo e da opção Propriedades no Word, garantindo, dessa forma, o critério de sigilo da revista, caso submetido para avaliação por pares (ex.: artigos), conforme instruçóes disponíveis em Assegurando a Avaliação por Pares Cega.

\section{DECLARAÇÃO DE DIREITO AUTORAL}

Autores que publicam nesta revista concordam com os seguintes termos:

1. Autores mantêm os direitos autorais e concedem à Revista o direito de primeira publicação, com o trabalho simultaneamente licenciado sob a Creative Commons Attribution License, permitindo o compartilhamento do trabalho com reconhecimento da autoria do trabalho e publicação inicial nesta Revista.

2. Autores têm autorização para assumir contratos adicionais separadamente, para distribuição não exclusiva da versão do trabalho publicada nesta revista (ex.: publicar em repositório institucional ou como capítulo de livro), com reconhecimento de autoria e publicação inicial nesta Revista.

3. Autores têm permissão e são estimulados a publicar e distribuir seu trabalho online (ex.: em repositórios institucionais ou na sua página pessoal), a qualquer ponto, antes ou durante o processo editorial, já que isso pode gerar alteraçóes produtivas, bem como aumentar o impacto e a citação do trabalho publicado (veja o efeito do acesso livre).

\section{POLÍTICA DE PRIVACIDADE}

Os nomes e endereços informados nesta Revista serão usados exclusivamente para os serviços prestados por esta publicação, não sendo disponibilizados para outras finalidades ou a terceiros. 


\section{S) Editoração: \\ UFRe Gráica da UFRGS \\ Rua Ramiro Barcelos, 2500 \\ GRÁ FICA Porto Alegre/RS \\ DA UNIVERSIDADE FEDERAL grafica@ufrgs.br \\ DA UNIVERSIDADE FEDERAL RIO GRANDE DO SUL WWW.ufrgs.br/graficaufrgs}

Núcleo de Editoração e Revisão da Gráfica da UFRGS | 2017 